Portland State University

PDXScholar

Fall 1-9-2020

\title{
Rebranding Empire: Consumers, Commodities, and the Empire Marketing Board, 1926-1933
}

Ashley Kristen Bower

Portland State University

Follow this and additional works at: https://pdxscholar.library.pdx.edu/open_access_etds

Part of the European History Commons

Let us know how access to this document benefits you.

\section{Recommended Citation}

Bower, Ashley Kristen, "Rebranding Empire: Consumers, Commodities, and the Empire Marketing Board, 1926-1933" (2020). Dissertations and Theses. Paper 5397.

https://doi.org/10.15760/etd.7270

This Thesis is brought to you for free and open access. It has been accepted for inclusion in Dissertations and Theses by an authorized administrator of PDXScholar. Please contact us if we can make this document more accessible: pdxscholar@pdx.edu. 


\title{
Rebranding Empire:
}

Consumers, Commodities, and the Empire Marketing Board, 1926-1933

by

\section{Ashley Kristen Bower}

A thesis submitted in partial fulfillment of the requirements for the degree of

\author{
Master of Arts \\ in \\ History
}

\section{Thesis Committee: \\ Joseph Bohling, Chair \\ Richard Beyler \\ Chia Yin Hsu}

Portland State University

2019 


\begin{abstract}
$\underline{\text { Abstract }}$
The Empire Marketing Board (EMB) was a British government organization established in 1926 by the Conservative Party, under the authority of Colonial Secretary Leopold Amery. Its goal was to encourage Britons to "Buy Empire," namely, to buy products from the Dominions and colonies of the British Empire. To encourage consumption, the EMB funded scientific research and economic analyses, as well as publicity for Empire trade in the form of posters, films, educational materials, and government-sponsored events. The Empire Marketing Board attempted to sell the concept of "Empire" to the masses as a new cooperative project which stressed the value of imperial unity. However, its efforts conceal larger economic, political, and social tensions. Within the context of post-war economic decline and the ongoing criticism of empires, the work of the EMB reflected the need to modernize the Empire at a time when its future seemed less certain. In this way, the EMB's work becomes a prism from which to illustrate the challenges involved in rationalizing and consolidating the British Empire.

The 1920s witnessed the expansion of an internationalist agenda which stressed the value of political organizations such as the League of Nations, as well as more general processes of cultural exchange, intellectual cooperation and scientific and educational dialogue. Placing the EMB and its formation into the larger context of internationalism reveals how it attempted to reconfigure and reimagine the British Empire as a cohesive and cooperative "Commonwealth of Nations" rather than a dominating force. The reimagining of imperial ambitions as reconcilable with international considerations meant stressing empire as a liberal, voluntary union.
\end{abstract}


However, the idea of the Commonwealth as a political community always held underlying cultural and racial assumptions.

When the EMB was formed in 1926, the British Empire faced mounting pressures, both internationally and domestically. Diminishing markets for its manufactured goods, a dependence on foreign food, rising nationalism abroad, and high unemployment at home made the economic position of post-war Britain tenuous. The desire by political interests to form a closer economic union with the Empire, to fortify it against increasing foreign competition, on the international stage was complicated by a popular allegiance to free trade at home. The Empire Marketing Board was conceived of as a compromise, a way of encouraging the reorientation of trade, with the hope of keeping the Empire viable, while still appeasing consumers that relied on the cheap goods that Britain's free trade policy ensured. The EMB tried to sway consumers through government-sponsored persuasion rather than direct government intervention.

The EMB became a model for how the Empire could be reimagined in a new global context. In the EMB's conception of empire as an international cooperative project, everyone along the commodity chain would need to do their part to ensure the prosperity of the Empire, including producers, retailers, and—especially—consumers. The EMB mobilized individuals from many different parts of society: from politicians to public relations experts, artists and filmmakers to scientists and agriculturalists. The diverse array of experts were organized in the service of the Empire, to find new ways of not only selling its products but ensuring its future. The Empire Marketing Board sought to manufacture a demand for Empire products that would appeal to imperially-minded shoppers, and the extensive work it undertook to do so illustrates that consumers, though 
often overlooked, were a central component in the government's aims of maintaining the viability of the British Empire in the changing climate of the interwar years. 


\section{$\underline{\text { Acknowledgements }}$}

This thesis would never have been possible without a wide network of support. First and foremost, words could never properly convey my thanks to my advisor, Professor Joseph Bohling. Joe read more drafts of this thesis than he probably would have liked, but he was always eager to listen and provide helpful advice. His enthusiasm for this project helped me stay motivated, even when I had moments of doubt. I would never have made it to the finish line without his guidance.

Another special acknowledgement should be extended to Professors Chia Yin Hsu and Richard Beyler for serving on my committee and providing feedback for this project. Their expertise helped to broaden my perspective, helping me to think broadly as well as deeply. This work was made all the better by their insightful comments.

To all of my fellow graduate students, thank you for helping me to see things in a new light. Thank you for the discussions and critiques. Graduate school opened up my mind to many new and interesting fields and perspectives. I am grateful to have been in the company of such talented scholars.

This thesis also would never have come to fruition without my amazing family, friends, and coworkers. Thank you all for bringing me coffee in times of desperation, being a sounding board during the worst frustrations, and providing words of encouragement along the way. I know how fortunate I am to be surrounded by so many supportive people. This thesis would never have been possible without all of you. 


\section{$\underline{\text { Table of Contents }}$}

Abstract...................................................................

Acknowledgements..........................................................

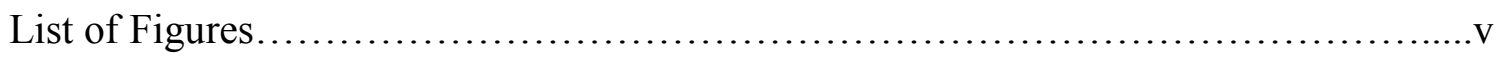

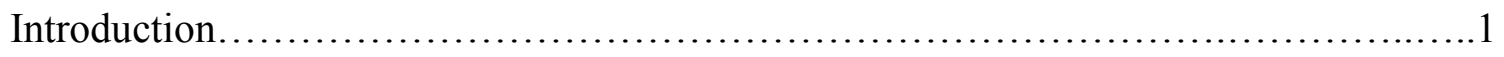

Chapter One

The Food Fight: Consumerism, Confederation, and the Free Trade Debate.............13

Chapter Two

Cultivating Commerce: Empire, Experts, and Networks of Science...................50

Chapter Three

False Advertising: Marketing, Misrepresentation, and the Branding of Empire..........94

Chapter Four

Alternative Facts: Publicity, Propaganda, and the Creation of the Imperial Family.....129

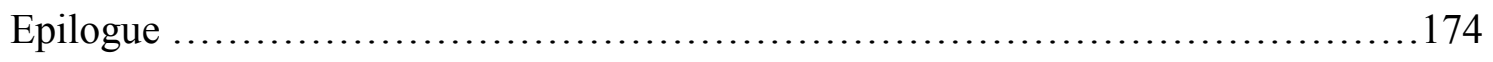

Bibliography....................................................... 185 


\section{List of Figures}

Figure 1. McDonald Gill, "Highways of Empire," map, c. 1927.................................

Figure 2. Walter Crane, "Imperial Federation Map of the World," c. $1886 \ldots \ldots \ldots \ldots \ldots . . .26$

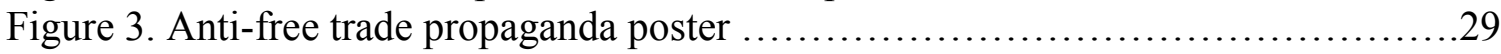

Figure 4. E. Huskinson. "What Price Today?.." Tariff Reform League propaganda

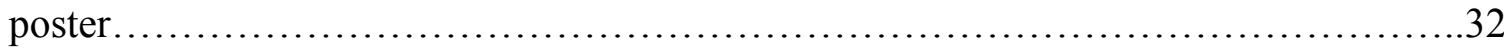

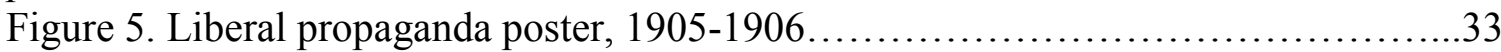

Figure 6. Empire Marketing Board poster illustrating the need to increase the Empire

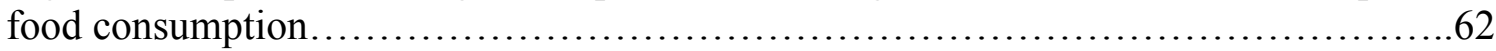

Figure 7. EMB poster showing increased Empire food consumption....................65

Figure 8. London Times advertisement for cold food storage ..........................68

Figure 9. London Times advertisement for research on pest control....................71

Figure 10. EMB advertisement illustrating British milk consumption...................73

Figure 11. Cadbury chocolate advertisement in the London Times......................76

Figure 12. EMB poster illustrating the Imperial College of Tropical Agriculture in

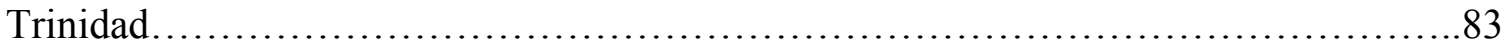

Figure 13. Frank Newbould, "Banana Harvesting in Jamaica," poster....................89

Figure 14. EMB promotional poster for Empire canned goods.........................103

Figure 15. EMB advertisement for Empire produce..................................104

Figure 16. EMB advertisement for Empire butter.................................110

Figure 17. EMB advertisement for Empire tea...................................111

Figure 18. Promotional poster for National Mark products..........................117

Figure 19.EMB advertising poster encouraging consumers to inquire about the origins of

their products................................................................. 120

Figure 20. Promotional "Buy British," poster produced for the Buy British campaign,

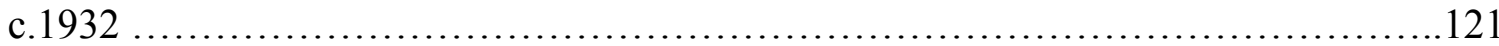

Figure 21. Frank Newbould, "Mutton, Lamb, Apples," c. 1932 ........................139

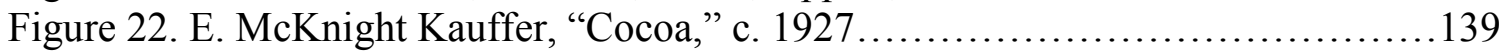

Figure 23. Ba Nyan, "Timber Stacking," c. 1928 ................................ 140

Figure 24. EMB advertisement encouraging the consumption of Empire products......141

Figure 25. Charles Pears, "Suez Canal," c. 1927.....................................143

Figure 26. Clive Gardiner, "Motor Manufacturing," c. 1928 .........................143

Figure 27. H.S. Williamson, "Drink Empire Grown Tea," series, c. 1931_.............145

Figure 28. Fred Taylor, "Empire Builders," c. 1927 ..............................148

Figure 29. F.C. Harrison, "Christmas Fare from the Empire," series, c. 1927 ...........150

Figure 30. H.S. Williamson, "John Bull, Sons and Daughters," c. 1928.................151

Figure 31. F.C. Harrison, "The Christmas Pudding," c. 1928 .........................153

Figure 32. Adrian Paul Allinson, "Empire Tobacco from Northern Rhodesia \&

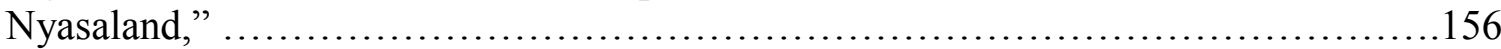

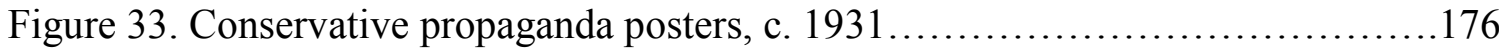

Figure 34. Harold Sanders Williamson, "Ottawa," poster.............................177

Figure 35. Harold Sanders Williamson, "Faces of Empire," poster.....................179 


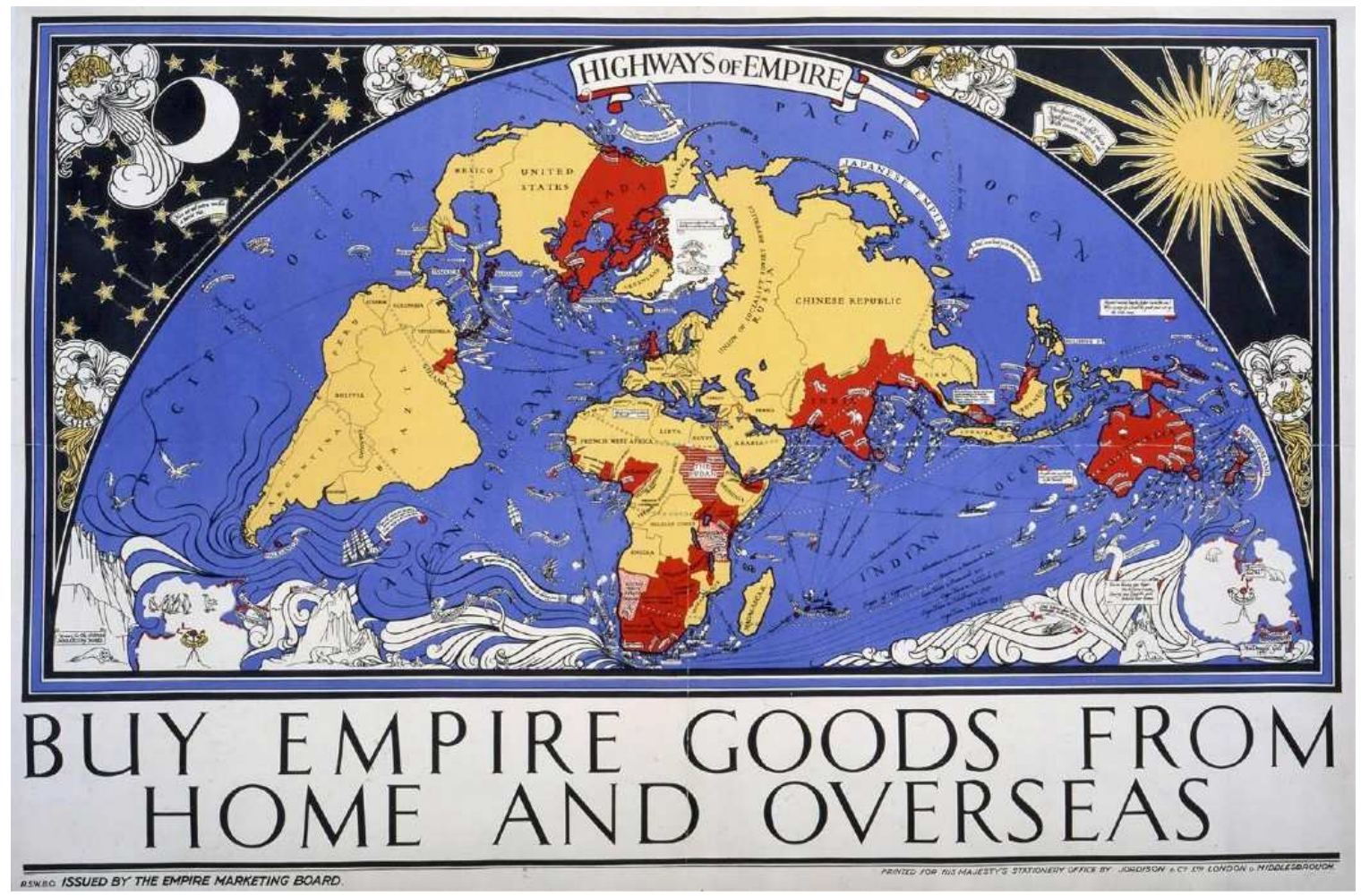

Figure 1. McDonald Gill, Highways of Empire. 1927. Color lithograph. Library and Archives Canada. Ottawa, Ontario. MIKAN 2988304. http://www.bac-

lac.gc.ca/eng/CollectionSearch/Pages/record.aspx?app=fonandcol\&IdNumber=2845248\&new=$\underline{8586313531152816049 \# 1-1}$

On New Year's Day, 1927 McDonald Gill's Highways of Empire billboard, measuring a sizable 20 x $10 \mathrm{ft}$., was unveiled over Charing Cross Road in Central London. It was the first poster produced by the Empire Marketing Board's new advertising campaign. During the EMB's short tenure, which lasted from 1926-1933, it would roll out hundreds of additional poster designs. The map illustrates a common perception of the British Empire, an expansive amalgamation of territories colored in red 
to denote Britain's connection to the larger Empire. ${ }^{1}$ The imagined geography of the map, altered to give onlookers a birds-eye-view of the entirety of the globe, illustrated the state of the Empire by the mid-1920s. Following the First World War, the British Empire stood as the largest Empire in the world. It covered almost a quarter of the Earth's total land area and held sway over a quarter of the global population. As the map also illustrates, the powerful navy helped to control the waterways and an expansive networks of shipping lanes, its "highways," helped to circulate goods all over the world. The map shows the connections that had emerged due to modern technology, facilitating the transfer of people and products in an age of increased globalization.

However, despite the expansiveness, strength, and cohesion illustrated by Gill's map, the height of British Empire went hand-in-hand with its increasing fragmentation. ${ }^{2}$ Britain had historically been an industrial powerhouse, commonly known as the "workshop of the world" due to its manufacturing capabilities. Increasingly, though, this economic hegemony was challenged by internal and external forces. From the late $19^{\text {th }}$ century through the early $20^{\text {th }}$ century, perpetual challenges - ranging from closing markets and military conflict abroad to economic decline and political divisions at home - had undermined this dominance. By the end of WWI, the new political

\footnotetext{
${ }^{1}$ By the 1920s, the Empire was administratively divided between "Dominions," and colonies. Dominions were largely self-governing, former settler colonies and included Canada, Australia, New Zealand, Newfoundland, South Africa, and the Irish Free State. The rest of the Empire was referred to as the "colonial Empire." Other territories, such as India and Southern Rhodesia, occupied a more ambiguous space between the two. ${ }^{2}$ Martin Thomas and Andrew Thompson, "Empire and Globalisation: From 'High Imperialism' to Decolonisation," The International History Review, 36, no. 1 (2014): 151.
} 
internationalism, shifting relations with the Empire, and debates on the best trade policy to ease Britain out of the post-War slump indicated ongoing international, imperial, and national concerns. New approaches were continually sought out to improve Britain's economic position and maintain the unity of the Empire in the changing political and economic climate.

This thesis looks to the Empire Marketing Board to illustrate the interests that helped to reconstitute the British Empire during the interwar period. The EMB mobilized a vast network of experts from within the political, scientific, business, and cultural spheres in order to facilitate and improve trade between Britain and the its Dominions and colonies by appealing to British shoppers. These efforts, it was hoped, would help to "tighten and secure the imperial knot," and ensure post-war economic prosperity. ${ }^{3}$ The British Empire and its resources increasingly became conceived of as a lifeline for maintaining imperial strength and unity at a time when its economic supremacy was increasingly challenged by rival powers.

After the First World War, Britain was in a somewhat contradictory position, at the height of Empire but also facing a set of complex challenges. The extensive efforts that went into the research and marketing of the Empire also raises a number of substantive questions. Why did the EMB need to promote Empire products? What were the EMB's aims in trying to project a decidedly different vision of the Empire's interwar

\footnotetext{
${ }^{3}$ James Murton. "John Bull and Sons: The Empire Marketing Board and the Creation of a British Imperial Food System," in Edible Histories, Cultural Politics: Toward a Canadian Food History, ed. Franca Iacovetta, Valerie J. Korinek, and Marlene Epps (Toronta: University of Toronto Press, 2012), 71.
} 
condition than actually existed? Also, why did it need to persuade shoppers to "Buy Empire Goods"? If money, personnel, and resources were levied to market the Empire to the public, it suggests that the current state of affairs was more precarious and less certain than some would presume. It also suggests that consumers were critical in the solution for remedying the Empire's economic position. This thesis argues that consumers played a central role in the remaking of the Empire after World War I. The EMB's work to foster the creation of a global Empire market necessitated rationalizing and streamlining the transfer of goods through scientific management, marketing, and publicity. Within the context of interwar internationalism, the Board emphasized the need for imperial cooperation, but it was ultimately through consumers that the success of such a system would be possible.

Within the historiography of imperialism there has been a tendency to focus on high politics or economic concerns, without investigating how imperialism was also shaped by consumer preferences. Classical theorists have largely focused on British elites as the driving force of imperialism. Investigations in the early $20^{\text {th }}$ century sought to examine the sources of emerging phenomena, namely increasingly aggressive foreign policies, high tariffs, increased arms production and increasing competition for domination and influence in overseas territories. ${ }^{4}$ John Hobson, in Imperialism: A Study (1902) pointed to the sudden advance of capitalism which saw financial elites promote imperialist policies through their political influence. It was these elites that pushed investment abroad in order to find new markets for goods and investment which largely

\footnotetext{
${ }^{4}$ Norman Etherington, Theories of Imperialism: War, Conquest and Capital (London; Canberra, Croom Helm, 1984), 164.
} 
aided financiers, merchants and manufacturers. ${ }^{5}$ Vladimir Lenin's interpretation in Imperialism, The Highest Stage of Capitalism (1917) alleged that imperialism was endemic to a specific time in history, when financial monopolies had eliminated free competition and the search for raw material to benefit the financial and manufacturing interests saw their apex with the seizure of foreign territories. ${ }^{6}$ Joseph Schumpeter's Imperialism and the Social Classes (1919) envisioned similar concerns in sociological terms, instead arguing that imperialism was not an inherent characteristic of a specific stage in the development of capitalism but that it remained part of a larger historical narrative. Throughout history, elites' will to power resulted in the drive for conquest in order to protect their status, imperialism in the $20^{\text {th }}$ century being only one manifestation of a larger ongoing phenomenon. ${ }^{7}$

Other interpretations influenced by the work of classical theorists have similarly focused on geopolitics or the financial elite. Ronald Robinson and John Gallagher's focus on the political and diplomatic facets of imperialism in their influential Africa and the Victorians: The Official Mind of Imperialism (1961) developed the thesis that empire was pursued by the "official mind" of British policymakers in order to protect trade routes to India. ${ }^{8}$ Peter Cain and Antony Hopkin's assessment has placed the area of focus on "gentlemanly capitalists," the influential elite of the service sector - namely interests in

5 J.A. Hobson, Imperialism: A Study. Nottingham: Spokesman, 2011; Daniel H. Kruger "Hobson, Lenin, and Schumpeter on Imperialism," Journal of the History of Ideas 16, no. 2 (April 1955): 253.

${ }^{6}$ Vladimir Lenin, Imperialism: The Highest Stage of Capitalism (Peking: Foreign Language Press, 1975).

${ }^{7}$ Joseph Schumpeter, Imperialism and Social Classes (New York, A.M. Kelly, 1951).

${ }^{8}$ Ronald Robinson and John Gallagher, Africa and the Victorians: The 'Official Mind" of Imperialism (Basingstroke, 1961). 
trade, finance, shipping and insurance. Their interpretation centered on "the City of London," and its influence on the political interests which helped to shape imperial policies. ${ }^{9}$ In more recent studies of imperialism in connection with interwar internationalism, there had been a similar tendency to focus on high politics. ${ }^{10}$

The role of consumers has often been neglected in theories of imperialism or investigations of the interwar years. A.R. Dilley has illustrated that consumer preferences, which form the "motor" of economic activity, are often absent from studies of imperial economics. In most accounts, he has emphasized, "the consumer is taken for granted." ${ }^{11}$ However, exceptions have included works such as Frank Trentmann's Free Trade Nation: Commerce, Consumption and Civil Society in Modern Britain (2008). Rather than taking a purely top-down approach, Trentmann has tried to establish "a new history of politics" that looks to the "changing practices, rituals, passions, and conflict" that reveal political matters as an evolving process concerning both global and local actors. Trentmann broadens the scope by exploring such high political concerns such as

${ }^{9}$ P.J. Cain and A.G. Hopkins, "Gentlemanly Capitalism and British Expansion Overseas. Part I: The Old Colonial System, 1688-1850." Economic History Review, $2^{\text {nd }}$ ser., 39, no. 4 (1986): 501-25; and "Part II: The New Imperialism, 1850-1945," Economic History Review 40, no. 1 (1987): 1-26.

${ }^{10}$ Such works include: Patricia Clavin, Securing the World Economy: The Reinvention of the League of Nations, 1920-1946 (Oxford: Oxford University Press, 2013); Erez Manela, The Wilsonian Moment: Self-Determination and the International Origins of Anticolonial Nationalism (New York: Oxford University Press, 2007); Mark Mazower, Governing the World: The History of an Idea (New York: Penguin, 2012); Susan Pedersen, The Guardians: The League of Nations and the Crisis of Empire (New York: Oxford University Press 2015); Robert Boyce's The Great Interwar Crisis and the Collapse of Globalization (Hampshire: Palgrave Macmillan, 2009).

11 A.R. Dilley, "The Economics of Empire," in The British Empire: Themes and Perspectives, ed. Sarah Stockwell (Malden: Blackwell, 2008), 122. 
British free trade in tandem with the agency of individual consumers in fashioning their own ideas about ethical consumption practices, illustrating how economic policies can depend on popular support. ${ }^{12}$ Erica Rappaport has similarly illustrated that imperialism was not just a system connected to the realm of industrialists, financiers, and members of government but reached out to the wider swathes of the population, the "imperial consumer citizen." ${ }^{13}$ Peter van Dam equally notes that consumers play a role in the market, that they shape and are shaped by larger forces. He argues that it is necessary to broaden the framework of inquiry, noting that "citizen-consumers...were not just situated within nation states, but were also affected by local, European, and global events and processes" 14 The investigation of consumption, though often neglected, informs the study of imperialism and larger global forces, as will be further explored.

The interest in the multiple actors that have influenced British imperialism has also led to investigations of larger imperial networks. David Cannadine has asserted that the one of the limitations of classical theories of imperialism is that they are largely monocausal, with one driving force, and insufficient in articulating the complexities of imperial study. ${ }^{15}$ Alan Lester has also shown the diverse nature of imperial connections

${ }^{12}$ Frank Trentmann, Free Trade Nation: Commerce, Consumption, and Civil Society in Modern Britain (Oxford: Oxford University Press, 2008), 19.

${ }^{13}$ Erika Rappaport, “'“Drink Empire Tea: Conservative Politics and Imperial Consumerism in Interwar Britain," in Consuming Behaviours: Identity, Politics and Pleasure in Twentieth-Century Britain ed. Erika Rappaport (Bloomsbury: New York; London, 2015), 151.

${ }^{14}$ Peter van Dam, "Tales of the Market: New Perspectives on Consumer Society in the $20^{\text {th }}$ Century," UvA-DARE (2015): 1.

${ }^{15}$ David Cannadine, "The Empire Strikes Back," Past and Present 147 (May 1995): 194; Andrew Porter, "'Gentlemanly Capitalism' and Empire: The British Experience Since 1750?" The Journal of Imperial and Commonwealth History 18, no. 3 (1990): 270-271. 
and has reconceptualized how those connections might be articulated. He has utilized "network," "web" and "circuit" metaphors, deviating from more traditional models of "core" and "periphery," to illustrate that there was not a single imperial project nor a single discourse but, rather, that colonial interests were often shaped by more extensive networks of influence. ${ }^{16}$ Tony Ballantyne has similarly argued that "webs" are better conceptual schemes for envisioning the "cultural traffic" of Empire - how actors, ideas, and goods were brought together - both horizontally from colony to colony as well as vertically between the metropole and colonies. ${ }^{17}$ Derba Gosh has advocated for further contextualizing and complicating British Empire studies, as new directions in imperial history have preference a "de-centered narrative in which there was no one driving force but rather multiple and unmanageable systems, processes, imaginaries, and contingent events that pushed a diversity of nations, empires, and communities, and their subjects in different directions" ${ }^{\prime 18}$ This thesis works within this framework, that a vast network of interests - political, scientific, intellectual, business, cultural - were mobilized during the interwar period in order to appeal to consumers and thereby maintain the strength of the Empire.

This thesis also intervenes in a commonly held distinction between "old" and "new imperial history" which have often divided approaches to studies of the British Empire. This division, which Stephen Howe has characterized as a "slow burning civil

\footnotetext{
${ }^{16}$ Alan Lester "Imperial Circuits and Networks: Geographies of the British Empire," History Compass 4, no. 1 (December 2005): 1; 10-12

17 Tony Ballantyne, Orientalism and Race: Aryanism and the British Empire (London: Palgrave Macmillan, 2002), 39.

18 Durba Ghosh, "Another Set of Imperial Turns?" American Historical Review 117, no. 3 (June 2012): 772-793.
} 
war" among historians of the British Empire, has tended to divide those who focus on high political, economic or military concerns and those focused on other varied topics such as ecological history, race, and gender ${ }^{19}$ The shift away from political and economic studies of imperialism began in the 1980s with the influence of postcolonial theory and "the cultural turn," initiated by works such as John MacKenzie's Propaganda and Empire: The Manipulation of British Public Opinion (1984). MacKenzie illustrated the many ways that the idea of empire was envisioned and experienced through visual and material culture within Britain and how the creation and propagation of the "imperial imaginary" affected the lives of British citizens" ${ }^{\prime 20}$ Subsequent work by other cultural historians have argued for the primary place of the cultural within the realm of imperial history. ${ }^{21}$

Athena Syriatou has more recently argued that the dividing line between old and new is more porous than traditional divisions might suggest. ${ }^{22}$ Donna Loftus has noted a return to investigations of the market in the more recent "material turn" within cultural studies. As she points out, "markets are fundamentally about people, the environment and

\footnotetext{
${ }^{19}$ Stephen Howe, "Introduction," in The New Imperial History Reader, ed. Stephen Howe (London; New York: Routledge, 2010), 1-2.

${ }^{20}$ John M. MacKenzie, "Passion or Indifference? Popular Imperialism in Britain Over Two Centuries," in European Empires and the People: Popular Responses to Imperialism in France, Britain, the Netherlands, Belgium, Germany, and Italy, ed. John MacKenzie (Manchester: Manchester University Press, 2011), 61.

${ }^{21}$ For example, Antoinette Burton, Burdens of History: British Feminists, Indian Women and Imperial Culture, 1865-1915 (Chapel Hill; London: University of North Carolina Press, 1994); Catherine Hall, Civilising Subjects: Metropole and Colony in the English Imagination, 1830-1867 (Oxford: Polity, 2002); Kathleen Wilson, A New Imperial History: Culture, Identity and Modernity in Britain and the Empire 1660-1840 (2004). ${ }^{22}$ Athena Syriatou, "National, Imperial, Colonial and Political: British Imperial Histories and their Descendants," Historein 12 (2013): 56.
} 
access to resources," which "demands adaptive political economies."23 Culture and markets are often intertwined because economic forces affect and are affected by social, ecological, cultural and political influences. Dane Kennedy has also illustrated that the growing interest in consumption, commodities and material culture may be one way to “integrate the material, cultural, and epistemological dimensions of imperialism into a post-postcolonial synthesis," bringing both new and old into the fore. ${ }^{24}$ Thus, the EMB's attempts at selling seemingly mundane products - from bananas to butter - either through their representation or through the commodities themselves, upon closer examination reveal larger underlying stories that do not lend themselves easily to distinctions between old and new.

This thesis examines how the EMB envisioned a new imperial market and how they attempted to bring that vision to life for consumers. Though much of the work on the EMB has tended to focus on its posters and film, relatively little has been written about its other initiatives. ${ }^{25}$ This work will look holistically at the Board's objectives to more

${ }^{23}$ Donna Loftus, "Markets and Culture," in New Directions in Social and Cultural History, ed. Sasha Handley, Rohan McWilliam, and Lucy Noakes (London: Bloomsbury, 2018), 120.

${ }^{24}$ Dane Kennedy, The Imperial History Wars: Debating the British Empire. (London: Bloomsbury, 2018), 55.

${ }^{25}$ Works on the Empire Marketing Board have tended to focus more heavily on its visual and material culture, rather than dealing with the EMB holistically. See, for example, Melanie Horton, Empire Marketing Board Posters: Manchester Art Gallery (London: Scala, 2010), David Meredith, "Imperial Images: The Empire Marketing Board, 192632," History Today (1987): 30-36; Stephen Constantine, "Bringing the Empire Alive:' The Empire Marketing Board and Imperial Propaganda 1926-33," in Imperialism and Popular Culture ed. John MacKenzie (Manchester: Manchester University Press, 1986), Tim Buck, "Imagining Imperial Modernity in British Colonial West Africa: Gerald Spencer Pryse's Work for the Empire Marketing Board," Art History 38, no. 5 (November 2015), Mike Cronin, "Selling Irish Bacon: The Empire Marketing Board Artists of the Free State," Éire-Ireland 39:3\&4 (Fall/Winter 2004), Nadine Chan, 
fully examine its work and its message. The first chapter will illustrate the development of the EMB within the context of other earlier concerns, such as the debate on free trade, attempts at imperial federation, and interwar internationalism. The EMB had three major aims in their mandate: scientific development, marketing, and publicity. Chapter 2 will explore more about the scientific research that was funded by the EMB. Though most of the Board's funding went to science-related activities, relatively little has been written about its studies or how scientists worked to investigate and restructure the natural environment to meet consumer demands. ${ }^{26}$ Chapter 3 examines another of the lessexplored aims of the EMB, marketing. ${ }^{27}$ The EMB worked with producers and retailers to figure out the best ways to sell products to consumers. The EMB's economic analyses became some of the first instances of what might today be called market research, attempts at trying to predict and monitor purchasing patterns. This chapter will explore more about how they utilized the marketing tactics of industry to further their aims of empire development, and the challenges posed by foreign competitors. Chapter 4

\footnotetext{
'Remember the Empire, Filled with Your Cousins:' Poetic Exposition in the Documentaries of the Empire Marketing Board." Studies in Documentary Film 7, no. 2 (2013), and Uma Kothari, "Trade, Consumption and Development Alliances: The Historical Legacy of the Empire Marketing Board Poster Campaign" Third World Quarterly 35, no. 1 (2014): 43-64.

${ }^{26}$ An exception is the work of P.J. Atkins, who has examined the scientific work of the EMB in comparison with its other aims. See P.J. Atkins "Food and the Empire Marketing Board in Britain, 1926-1933." Paper presented at the 8th Symposium of the International Commission into European Food History, Prague, Czech Republic (October 2003), 4.2.

${ }^{27}$ Stephan Schwarzkopf, who had explored the EMB's marketing aims and the connection between British advertising and the interwar government, is another exception. See "Market, Consumers, and the State: The Uses of Market Research in Government and the Public Sector, 1925-1955," in The Rise of Marketing and Market Research, ed. Hartmut Berghoff, Philip Scranton, and Uwe Spiekermann (New York: Palgrave MacMillan, 2012).
} 
examines the last of the EMB's aims, publicity. It looks at the posters and film of the EMB, but also the ways the ways in which empire was portrayed through exhibitions and shopping weeks. This section also explores the development of public relations under the EMB and the ways in which the media was utilized and developed by the EMB to educate the public about the Empire.

The following pages will illustrate how the Empire Marketing Board mobilized a diverse set of actors to help to remake the Empire as international cooperative project, and how that project hinged on citizens with a common set of imperial values. In the face of economic decline, the array of expertise that were assembled to help shift consumer preferences away from foreign competitors signaled its precarious position. Faced with an uncertain future, the British government turned its attention to an often-overlooked resource - that of consumers. The success of the Board's aims depended on consumer's acceptance of its message and their willingness to buy from the Empire. This study will investigate the vital role that consumers played in this imperial reimaging, the crux of the newly-envisioned world order. 


\section{Chapter One}

The Food Fight: Consumerism, Confederation, and the Free Trade Debate, 1846-1926

The formation of the EMB in 1926 represented an appeal to consumers, encouraging them to buy imperially for the benefit of the Empire. To explain why such a program might be initiated, it is necessary to explore more about the EMB's origins. A key piece of the equation was the debate over free trade. Free trade remained a popular policy in Britain because it helped to ensure cheaper food prices for consumers. The free trade system was initiated in Britain in the mid-nineteenth century, but it was a policy that was contested by different interests throughout the later decades. This chapter traces some of the developments that led to the EMB's formation, first, with a brief history of the move to free trade, and then developments in the later nineteenth century, the turn of the century, and the new international landscape of the post WWI period. Establishing a chronology of events helps to illuminate why a network of experts were mobilized to sell Empire goods to consumers, and why the interest in consumer demands became so essential after the First World War. The establishment of the EMB reflects longer, more entrenched battles that centered on the needs and desires of domestic consumers.

\section{Free Trade and the Rise and Fall of the Corn Laws}

At the beginning of the nineteenth century, Britain stood out as a leading economic power. It maintained control of the seas and enjoyed technological advantage over other nations due to the mechanization of the Industrial Revolution and the control of the resources of its Empire. Britain's demand for foreign markets was facilitated by the 
Empire, though a large portion of its manufactures also went to Europe and the Americas. Like most of Europe, Britain began the century with protectionist policies in place. This meant that imported goods were taxed, largely to shelter domestic industries. The passage of the Corn Laws in 1815 had been designed to protect British landowners by implementing tariffs on foreign grains. The Corn Laws formed part of a larger protectionist structure that, at the same time, privileged the importance of commerce with British colonies. While preferential measures were put into place for goods from the colonies - including products such as sugar, timber, and coffee - many other imported goods were subjected to prohibitions and tariffs.

The Corn Laws, however, were also controversial as they were considered by some to further the interests of wealthy. As the century wore on, some began to reevaluate Britain's protectionist trade policies. The Select Committee on Import Duties reported by 1840 that seventeen items represented 95 percent of customs revenue; with some traders, bureaucrats, and political radicals considered the remaining duties, numbering over one-thousand, to be both unwarranted and expendable. ${ }^{28}$ British exporters believed that if agricultural tariffs were eliminated, it would lower the cost of goods, and increase the competitiveness of manufactures. It was also thought that other countries had been raising tariffs on British manufactures in retaliation for Britain's own agricultural protection, and it was theorized that liberalizing trade could encourage other

${ }^{28}$ Anthony Howe, Free Trade and Liberal England, 1846-1946 (Oxford: Clarendon, 1997), 2. 
nations to reduce their barriers in kind. ${ }^{29}$ It was assumed that such a move would stabilize wages and food prices, thereby creating a more stable social order.

The issue of free trade entered parliamentary debates early in the nineteenth century. Though earlier prime ministers such as Robert Walpole had advocated for free trade as early as 1721 , and William Pitt had done so in 1783 , the movement gained momentum in Parliament by $1820 .{ }^{30}$ Some politicians supported free trade based on the belief that it would increase national wealth. They were also influenced by the theories of classical economists like Adam Smith and David Ricardo who, as a prominent member of the House of Commons at the time, continued to advocate for free trade. However, politicians in the House of Commons were more cautious than economic theorists. Customs duties provided revenue for the national debt and other fiscal needs and shipbuilding interests were influential, so political leaders hoped to move toward removing restrictions gradually. ${ }^{31}$ The President of the Board of Trade, William Huskisson, helped to pass The Reciprocity of Duties Act of 1823. This permitted the reciprocal removal of duties through bilateral trade agreements with other nations, signaling movement toward more liberal policies.

Free trade also drew some of its most enthusiastic support from outside the realm of Parliament. The Anti-Corn Law League (ACLL), founded in 1838 by Richard Cobden and John Bright, utilized its own propaganda to mobilize consumers and bring economic

${ }^{29}$ Andrew G. Brown, Reluctant Partners: A History of Multilateral Trade Cooperation (Ann Arbor: University of Michigan Press, 2003), 51-52.

${ }^{30}$ William D. Grampp, "How Britain Turned to Free Trade." The Business History Review 61, no. 1 (Spring 1987): 86.

${ }^{31}$ Ibid., 93. 
concerns into the public arena. The ACLL helped to organize middle-class consumers in support of free trade. The League found its greatest support among the textile industry but was able to gain broader support by marketing itself as supporting the national interest. It avoided the issue of class by envisioning consumers collectively as "the people" united against landowners, the "parasitic vestiges of an outdated feudal order," who were only impoverishing the majority though unfair taxation. ${ }^{32}$ The symbolism of bread served to reinforce its ideas and its propaganda campaign. The ACLL often illustrated the dangers of the Corn Law "bread tax" by displaying bread in public spaces. The ACLL used public demonstrations to illustrate the difference between free trade and protectionism as the difference smaller and larger loaves of bread. They argued that cheaper bread would help to feed workers, which would in turn put more income into the economy for goods, and result in improvement for all consumers while protectionism would only lead to hunger. ${ }^{33}$

However, the attempts by the ACCL to convert the working classes to their cause was less successful. The working-class Chartists had unified under the belief that the issue of hunger could not be solved until working class was given voting rights and a greater share of political power. They argued that a combination of political intervention and regulation was necessary to prevent consumers from being exploited by industrial capitalism, a marked difference from the hands-off approach desired by free traders.

32 Peter Gurney, The Making of Consumer Society in Britain (London: Bloomsbury, 2017), 3.

${ }^{33}$ Peter J. Gurney, "Rejoicing in Potatoes': The Politics of Consumption in England During the "Hungry Forties," Past and Present 23 (May 2009), 103. 
Chartists boycotted shops that opposed their aims and established their own co-operative stores. ${ }^{34}$ They also sought to mount a similar mass movement against free trade, utilizing similar political tropes as those of the ACLL. When economic depression hit in the 1840's, hunger was widespread and this lead to further unrest. It helped to cement divisions between classes, especially surrounding the issue of food, which became an increasingly volatile point of contention.

However, protectionism still held sway in many regions. Many believed that it created a stable home market for manufacturing and agricultural goods, which also helped to ensure political and social stability. Chartists and Conservative protectionists were able to form temporary alliances, especially in urban areas, over their common antagonism toward the ACLL. ${ }^{35}$ Advocates for protectionism also voiced opposition to free trade because of the tax burdens that they believed would fall on agriculture and the assumption they would be unable to compete with cheaper foreign corn. ${ }^{36}$ In popular petitions to the government, both free traders and protectionists accused the other of scheming; free traders arguing that landlords in agricultural areas exerted pressure on workers to petition the government while protectionists accused free trader manufacturers of compelling employees to sign anti-Corn Law petitions. ${ }^{37}$ Both sides sought to use the issue of hunger to further their political goals.

\footnotetext{
${ }^{34}$ Guerney, The Making of Consumer Society in Britain, 51.

${ }^{35}$ Henry James Miller, "Free Trade and Print Culture: Political Communication in Early Nineteenth-Century England," Cultural and Social History 14, no. 1 (2017): 40.

${ }^{36}$ Henry Miller, "Popular Petitioning and the Corn Laws, 1833-46," The English Historical Review 127, no. 527 (2012): 896.

37 Ibid., 897.
} 
The momentum for repeal of the Corn Laws came in large part from the Radicals in the Board of Trade, and their connection to the Anti-Corn Law League. ${ }^{38}$ Tory Prime Minister Robert Peel was convinced of the merits of free trade by the Board of Trade, based on the understanding that it would help increase revenue, which was imperative given that by 1842 Britain had been running at a deficit for four years. ${ }^{39}$ Peel tried to take the heat out of the "hunger politics" of the day by stressing the connection between free trade and fairness for the consumer. The movement toward freer trade was evident in the reduction of 750 duties in 1842 , and a further 450 in $1845 . .^{40}$ The removal of duties was gradual because the landed gentry held considerable power and strongly resisted reform. However, when faced with multiple bad harvests and the onset of the Irish potato blight in 1845 , resulting in widespread famine, free trade ultimately won out and the Corn Laws were repealed the following year. William Gladstone's 1860 budget, nicknamed "The People's Budget," under the newly-created Liberal Party raised taxes on the middle classes and further reduced duties on goods representing "the luxuries and comforts of the mass of the people," such as tea, cocoa, apples, nuts, butter, and eggs - and eliminated duties on a further 123 articles. ${ }^{41}$ This effectively made Britain a nation of free trade.

\footnotetext{
${ }^{38}$ Howe, Free Trade, 3.

${ }^{39}$ Ian McLean and Camilla Bustani, "Irish Potatoes and British Politics: Interests, Ideology, Heresthetic and the Repeal of the Corn Laws," Political Studies 47 (1999): 819-820.

${ }^{40}$ Howe, Free Trade, 4.

${ }^{41}$ W.E Gladstone, The Financial Statement - The Budget, 18 April 1853. Parliamentary Debates, Commons, vol. 125, col. 1416.
} 
Free trade had a profound effect on Britain's economy. Economic growth between 1860 and 1880 was one of the largest ever recorded in British history. ${ }^{42}$ The influx of grain from Russia and North America, which could outcompete domestic farmers in Britain due to their lower costs of production, led to cheaper food for the general population, especially the working class. Falling food prices helped to feed the new urban populations that had flocked from farms to factories. What made the movement toward free trade in Britain so potent, though, was the degree to which the populace held to its ideals. The class divisions that had caused conflict in the earlier nineteenth century were blurred with the abolishing of the Corn Laws. Rather than being simply associated with self-interest, free trade and consumption became associated with social justice at home and international cooperation abroad. It was this widespread narrative of free trade that would play a role in the formation of the EMB decades later.

\section{The (First) Great Depression and the Turning Tide of Free Trade}

Not long after the repeal of the Corn Laws, questions about tariffs and trade resurfaced. The Great Depression, beginning in 1873, paralleled many events that would recur in the later Depression of the 1930s. The catalyst of the downturn was the investment of European funds in United States rail stocks. The crash of the Vienna Stock Exchange in May led to a string of bankruptcies. With Germany withdrawing investments from American railways, American banks beginning to fail by September. The Bank of England raised its reserves by hiking its bank rate to 9 percent when it had

${ }^{42}$ Paul Bairoch," Free Trade and European Economic Development in the $19^{\text {th }}$ Century," European Economic Review 3 (1972): 240. 
been 2 percent in the previous decades. ${ }^{43}$ The exacerbation of the Great Depression of the nineteenth century has also been variously attributed to other factors- including overproduction, the scarcity of gold, tariff protection, increased competition, speculation, the unproductiveness of foreign loans, and bad harvests. ${ }^{44}$

The period also saw a fall in the production capacity of major industries in Britain. Iron, steel, coal and cotton - the same industries that had driven the Industrial Revolution - began to stagnate in comparison to the rapid industrialization of nations such as Germany and the United States. This was due, in part, to a failure to modernize factories and develop new processes due to higher cost of replacement and technical education. ${ }^{45}$ Wages generally remained constant and food prices fell. ${ }^{46}$ However, the improvement of wages and the working-class standard of living also went hand-in-hand with reduced profits, damaged business confidence, limited productivity and investment, and higher unemployment. ${ }^{47}$ Workers in the coal, metal, engineering, and shipbuilding trades often had higher unemployment rates than other industries. ${ }^{48}$ Britain also lagged behind Germany and the U.S. in emerging technologies such as chemicals and electrical engineering. ${ }^{49}$ Between 1873 and 1913, the growth rate for the United States reached 4.8 percent, Germany reached 3.7 percent, while Britain reached only 1.8 percent.

${ }^{43}$ James Vernon, The Cambridge History of Britain: Modern Britain 1750 to the Present. (Cambridge: Cambridge University Press 2017), 179.

${ }^{44}$ A.E. Musson, "The Great Depression in Britain, 1873-1896: A Reappraisal" The Journal of Economic History 19, no. 2 (June 1959): 203.

${ }^{45}$ Ibid., 206.

${ }^{46}$ Vernon, The Cambridge History of Britain, 180.

${ }^{47}$ Munson, "The Great Depression in Britain, 1873-1896," 205-206.

${ }^{48}$ Ibid., 202.

${ }^{49}$ Ibid., 207. 
The growing trade imbalance in Britain was yet another concern. With growing competition abroad, British exports had decreased while the import of foreign manufactures, food, and raw materials increased - leading to a greater trade imbalance and a growing deficit. ${ }^{50}$ Governments abroad had begun to introduce tariffs to protect manufacturing - Russia in 1874, the United States in 1875, Germany in 1879, and France in 1892. This also coincided with rising nationalist political movements abroad that advocated for protectionist policies. ${ }^{51}$ By the late 1870 s, Belgium, Switzerland, AustriaHungary, Sweden, Italy, Spain, and Portugal had instituted higher tariffs. ${ }^{52}$ The McKinley Tariffs, introduced by the United States in 1890 in the hope of protecting new industries from British manufactures and uncertain economic conditions, also had a reverberating effect on British trade. Surrounded by tariff walls, some began to question free trade as a driving ideology.

The National Fair-Trade League (NFTL) was formed in August 1881 to campaign for the protection of agriculture and industry, the strongest support coming from regions that had been hit hardest by tariff barriers and foreign imports - Sheffield, Birmingham, and Bradford. ${ }^{53}$ Fair Traders argued that, in the face of increased foreign competition, resources should be directed to Britain and its territories rather than foreign nations. It

\footnotetext{
${ }^{50}$ Ibid., 213-14.

${ }^{51}$ Selcuk Bali, "Comparisons Between the Long Depression, Great Depression, and the Global Financial Crisis," International Journal of Management Economics and Business 8, no. 16 (2012): 236.

${ }^{52}$ William-Marc Palen," Protection, Federation and Union: The Global Impact of the McKinley Tariff Upon the British Empire, 1890-94" The Journal of Imperial and Commonwealth History 38, no. 3 (September 2010): 397.

${ }^{53}$ Andrew S. Thompson, Imperial Britain: The Empire in British Politics, c. 1880-1932 (Harlow: Pearson, 2000), 83.
} 
proposed the introduction of retaliatory tariffs on foreign goods but affirmed that those from the Empire should enter freely. On the issue of food, Fair-Traders were concerned with the trade imbalance, especially the growing imbalance between Britain and American food imports. ${ }^{54}$ Lloyd S. Sampson, Chairman of the Free Trade League, illustrated in a letter to the Times about the dangers of "excess imports," which resulted in "the better for some of the rich; but the worse in the long run for the poor - no matter how 'cheap' things may be." 55 He also argued that protection was essential for the number of struggling workers that lost out at the hands of foreign imports. ${ }^{56}$ Empire trade and preferences increasingly became conceived of as a solution to the ongoing depression of trade.

The emergence of the National Fair Trade League also led to greater efforts to sustain free trade by the Cobden Club, named in honor of Richard Cobden, one of free trade's earlier champions. The Club led a mass movement to maintain popular support for free trade. They argued that free trade had helped the working class, leading to greater prosperity, eliminating scarcity, and increasing wages. Prime Minister William Gladstone was himself a member. The Cobden Club circulated pamphlets such as George Webb Medley's Reciprocity Craze (1881) which argued against the "reciprocity or retaliation" chant that became popular among Fair-Traders. For Webb, protectionism simply led to a

\footnotetext{
${ }^{54}$ Sampson S. Lloyd. The Fair-Trade Position Explained: Being a Series of Three Letters Addressed by Mr. Sampson S. Lloyd as Chairman of the Free Trade League, to the Times and other Newspapers (London: The National Fair-Trade League, 1884 ), 17.

${ }^{55}$ Ibid., 9.

56 Ibid., 18.
} 
"minimum of production at the maximum of cost." ${ }^{57}$ George Potter's The Working Man's View of Free Trade (1881) - reflected the Club's ongoing attempts to recruit the working class and which helped to contribute to the long tradition of working class allegiance to free trade during the late-Victorian era (1837-1901) and beyond..$^{58}$ Deliberations about economic conditions, both past and present, led to differing solutions, either maintaining the status quo or by developing alternatives such as restoring some variation of protectionism. The interest in protectionism and protecting domestic producers was ratcheted up as competition and unemployment worsened, a pattern that would reemerge when world events became more calamitous.

\section{Empire Unity and the Imperial Federation League}

By the 1880s new political currents had taken over Europe. New federations in Italy, Germany, and Austria-Hungary gave the impression that many national communities were moving in the direction of union. Charles Dilke's popular travelogue Greater Britain (1868) had helped to create the terminology of unity in discussions among proponents of federation. Historians like John Seeley in his Expansion of England (1883) noted the importance and value of the Empire at a time of rapid population growth in the settler colonies. Seeley stressed that Britain would not be able to compete with emerging powers like Germany and the United States. The only way the Empire might retain its status was by forming greater political and economic ties, uniting into a

${ }^{57}$ George W. Medley. The Reciprocity Craze: A Tract for the Times (Castell, Petter, Galpin, \& Co. London, Paris, New York, 1881), 26.

${ }^{58}$ Howe, Free Trade, 130. 
"Greater Britain." The idea of Greater Britain was increasingly utilized by imperialists to stress the physical and psychological connection between British citizens at home and their brethren abroad.

Much of the promotion of a Greater Britain was based on the belief that the continued growth of the settler colonies would aid future trade between the Dominions and Britain. The rise of modern technologies, such as transportation and communications, also helped to make some form of imperial federation seem like a viable option. ${ }^{59}$ Though the Dominions accounted for a small percentage of trade with Britain, it was thought that investment and migration would improve their prospects as untapped markets. ${ }^{60}$ Proponents of imperial federation also stressed the cultural links between Britain and the Dominions, this creating an attractive alternate trade bloc within the context of increased foreign competition and rising tariffs abroad. ${ }^{61}$ The fear that utilitarian free trade would lead to citizens becoming more self-concerned and unpatriotic, was also a concern. Such a development would lead, in the mind of many, to imperial neglect or outright anti-imperialism. ${ }^{62}$ Protectionists increasingly pushed for

\footnotetext{
${ }^{59}$ Palen, "Protection, Federation and Union", 396.

${ }^{60}$ David Thackeray, Forging a British World of Trade: Culture, Ethnicity, and Market in the Empire-Commonwealth, 1880-1975 (Oxford: Oxford University Press, 2019), 7.

${ }^{61}$ Ibid., 3. Magee and Thompson have also illustrated the racial component to this conceptualization, pointing out that the trade networks that fostered imperial globalization largely "focused on particular [white] ethnic groups and exhibited a strong bias toward the empire's Anglophone societies," signaling the geographical as well as racial limitations of imperial relations. See Gary Magee and Andrew Thompson, Empire and Globalisation: Networks of People, Goods and Capital in the British World, c. 18501914 (Cambridge: Cambridge University Press, 2010), 61.

${ }^{62}$ Duncan Bell, The Idea of Greater Britain: Empire and Future of World Order, 18601900 (Princeton: Princeton University Press, 2007), 4.
} 
imperial cooperation as an alternative to foreign trade and sought to promote imperial trade through an emphasis on the cultural ties with the Dominions.

The Imperial Federation League (IFL) emerged in 1884 as one such group that advocated for greater imperial cooperation. The fear of foreign competition, socialism, social degeneration and mass politics contributed to the desire for a Greater Britain that could bring the Empire more firmly together. ${ }^{63}$ Propaganda for the IFL largely focused portrayed the Empire as a holistic, interconnected whole (Fig. 2) However, ideas of federation were always based on certain conceptions of imperial citizenship. The imagined community conceived of was largely concerned with the Anglo-Saxon settler colonies such as Canada and Australia where lands were ripe for cultivation and indigenous people went overlooked. ${ }^{64}$ Nations such as India, in the minds of many, did not fit within the framework of citizenship because it still required imperial governance. ${ }^{65}$ However, other countries were more problematic. The West Indies which, like South Africa, had a more racially diverse makeup, made conceptions of what populations constitutions admission into the "white" empire more ambiguous. It was for that reason that more problematic regions of the Empire, like the West Indies, were largely ignored by the League. ${ }^{66}$

${ }^{63}$ Palen, "Protection, Federation and Union," 35; 39.

${ }^{64}$ Martin Thomas and Andrew Thompson, "Empire and Globalisation: From 'High Imperialism' to Decolonisation," The International History Review 36, no. 1 (2014): 147. ${ }^{65}$ Peter Price, "Stepping Stones to Imperial Unity?: The British West Indies in the LateVictorian Imperial Federation Movement," Canadian Journal of History 52, no. 2 (Autumn 2017): 246.

${ }^{66}$ Ibid., 252-253. 


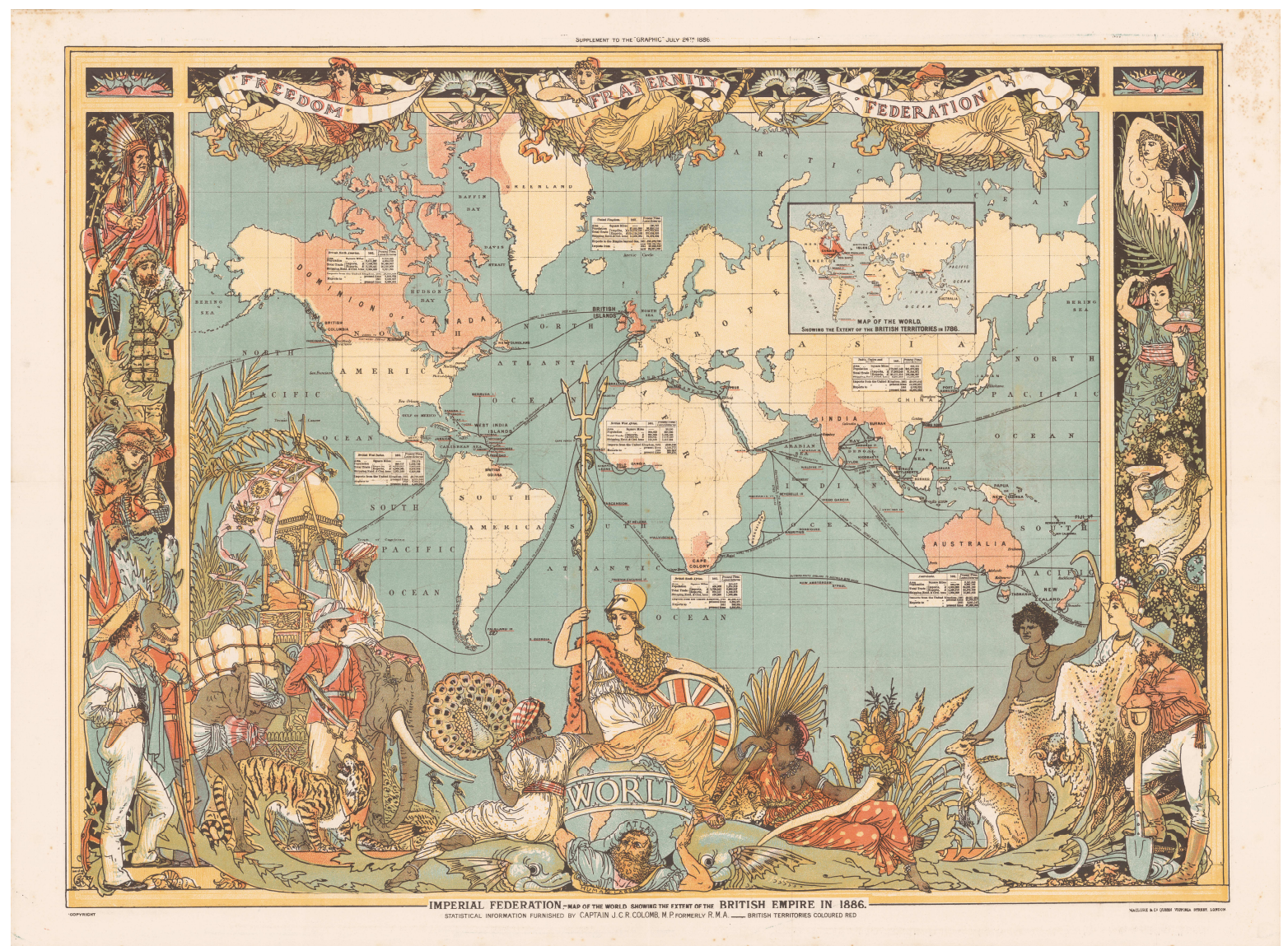

Figure 2. Walter Crane, Imperial Federation Map of the World, 1886, $58 \times 77 \mathrm{~cm}$. Cornell University Library Digital Collections. Ithaca, New York. https://digital.library.cornell.edu/catalog/ss:3293793

The problem with the IFL lay in its flexibility. The League contained proponents of federalism, those that desired more informal political advisory groups, and those that desired military or economic unions. ${ }^{67}$ It was also forced to contend with an Empire that was largely protectionist. The formation of an economic union between nations with popular support for different trade policies was difficult to reconcile. ${ }^{68}$ The movement

${ }^{67}$ John Kendle, Federal Britain: A History (London; New York: Routledge, 1997), 48. ${ }^{68}$ E.A. Benians, "Chapter VI: Finance, Trade and the Communications 1870-1895," in The Cambridge History of the British Empire, Volume II: The Empire-Commonwealth, ed. E.A. Benians, Sir James Butler, C.E. Carrington (Cambridge: Cambridge University Press, 1967), 220- 222 
failed to make headway among the higherups in Parliament, most of the activity occurring outside of its realm. Gladstone rejected proposals for federation submitted for consideration by the IFL as "nonsensical" in April 1893 and it lost steam soon after. ${ }^{69}$ One outgrowth of the movement was the first Imperial Conference in 1887, a meeting between Britain and Dominions to discuss political and economic concerns, an advancement that would last well until the lead up to the Second World War. It also led to business collaboration among empire interests, such as the Congress of the Chamber of Commerce of the Empire, which was used as a vehicle to further discuss imperial preference tariff arrangements. ${ }^{70}$ It also helped to open the door to more sustained efforts at economic cooperation between Britain and the Empire, which became seen during periods of decline as a means of improving domestic economic conditions.

\section{Joseph Chamberlain and Tariff Reform}

By turn of the century, Britain remained the only nation that continued to espouse a free trade ideology. The Edwardian Period (1901-1910) saw a resurgence of tariff debates under the aegis of industrialist and statesman Joseph Chamberlain. He served as a Liberal MP and as Colonial Secretary before resigning to take up the tariff reform campaign as a Liberal Unionist in $1903 .{ }^{71}$ Chamberlain emphasized the unfair nature of trade between Britain and other nations with high tariff policies and advocated for

${ }^{69}$ Bell, The Idea of Greater Britain, 16.

${ }^{70}$ Thackeray, Forging a British World of Trade, 24.

${ }^{71}$ The Unionist Party was coalition between the Conservatives and the Liberal Unionist Parties, which formed an alliance over their common opposition to Irish Home Rule. The Unionist Government lasted from 1895-1905; the parties would officially merge in 1912. 
retaliatory measures on trade if necessary." ${ }^{72}$ With tariffs increasing abroad, Chamberlain's solution was to reject free trade and instead introduce a system of imperial preference that would allow Britain to protect domestic industries while increasing potential Empire markets. He asserted that, "There is no article of your food, there is no raw material of your trade, there is no necessity of your lives, no luxury of your existence which cannot be produced somewhere or other in the British Empire, if the British Empire holds together." ${ }^{, 73}$ The future of the British economy, then, would depend on imperial trade. However, he was careful to emphasize that increased tariffs would not mean increased food prices for workers and consumers.

Chamberlain stressed the material benefits that would help the working class should preferential trade go into effect. Chamberlain provided an "alternative utopia" to the peaceful narrative of world trade that had been pushed by free traders. ${ }^{74} \mathrm{He}$ advocated for a new "radical Conservatism" which aimed at raising the working-class standard of living and other problems such as the dumping of sweated and prison goods. He affirmed that that poverty and hunger would only be solved by bridging the political and economic divide that had been a characteristic of free trade policy. ${ }^{75}$ Protectionist propaganda of the period also emphasized the dangers of the "the open door," Britain's free trade policy, in their promotion of tariffs (Fig. 3). As one poster shows, the influx of foreign goods has impoverished a British worker who, cold and with holes in his shoes, envisioned his

${ }^{72}$ Joseph Chamberlain. Imperial Union and Tariff Reform Speeches Delivered from May 15 to Nov. 4, 1903 (London: Grant Richards, 1903), 17.

${ }^{73}$ Charles W. Boyd ed. Mr. Chamberlain's Speeches: With an Introduction by the Right Hon. Austen Chamberlain, M.P. Volume II. London: Constable \& Company, 1914), 153. ${ }^{74}$ Guerney, The Making of Consumer Culture, 123.

75 Ibid. 124. 
family -- which also suffers. The emotional appeals of protectionist propaganda sought to illustrate that free trade ultimately let to the detriment of British laborers.

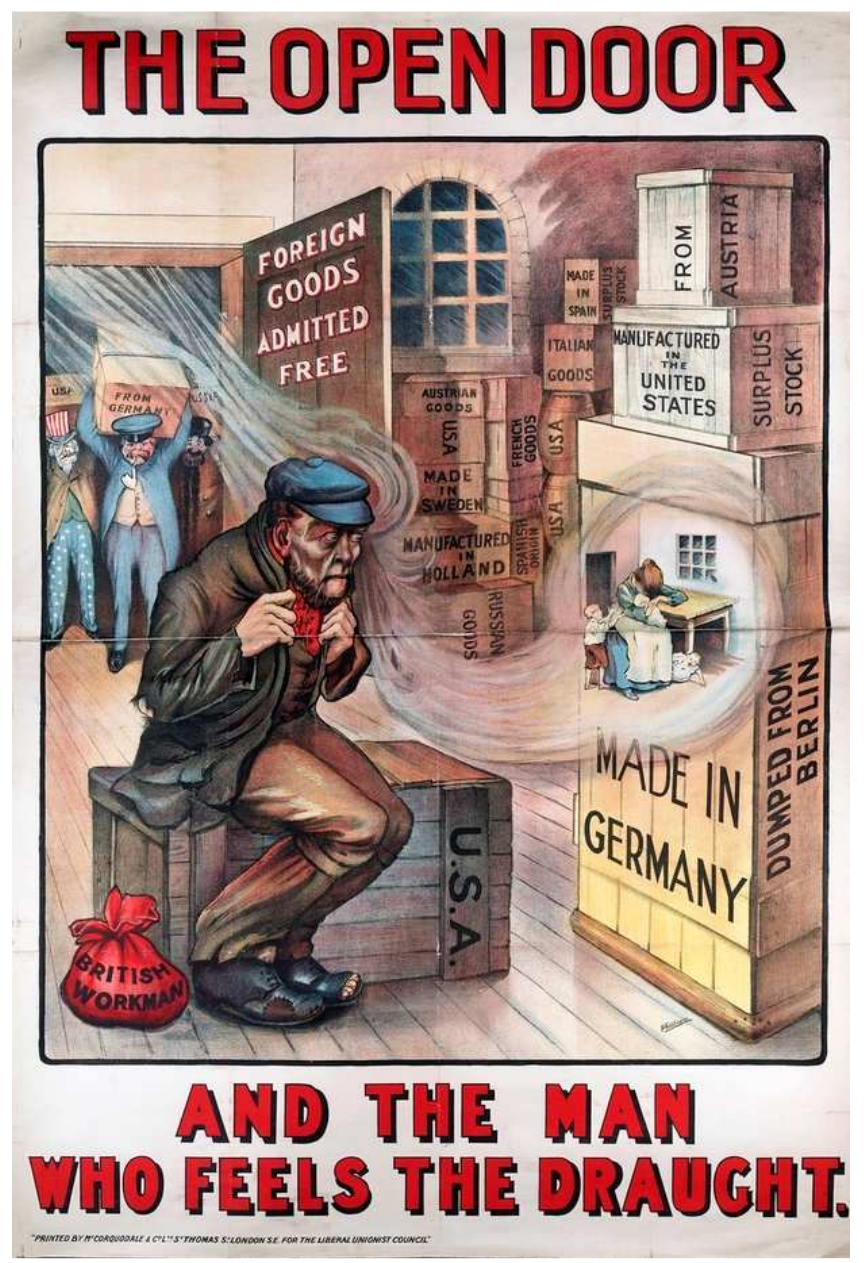

Figure 3. Liberal Unionist Party poster. The Open Door. London School of Economics Digital Library. London, England. https://digital.library.1se.ac.uk/objects/lse:mev399sam

The Tariff Reform League (TRL) was also formed in 1903. Chamberlain's tariff reform lobby was closely tied to the Conservative Party and advocated for the adoption of imperial preference. The TRL's aims included keeping out foreign manufactured goods, 
raising funds for pensions, and drawing the Empire more firmly together. ${ }^{76}$ It was hoped that such moves would help halt economic decline and help Conservatives rally behind a progressive policy to undercut emerging socialism. ${ }^{77}$ Chamberlain was referred to as an "advertising stateman" that understood how to use publicity to appeal to the masses. The TRL had its own think tank - the Tariff Commission - networks of local branches, a trade union association, and a notable propaganda campaign. ${ }^{78}$ The TRL's publication, Monthly Notes on Tariff Reform, also helped to circulate ideas about its cause. By July 1911 it asserted that, "The abandonment of the 'Free Trade' system is hardly an open question at all; it is a question only of time."79 It's efforts worked against the Liberal free traders who were criticized for allowing foreign goods to be dumped on British markets.

Edwardian conflicts continued debates that had started in the 1840 s, with free traders helping to propagate the idea of the "hungry forties," the dangers of higher food prices, and the potential for their return if tariff reformers got their way. ${ }^{80}$ Free traders, especially in the industrial north where cotton and shipbuilding industries dominated, argued that preference amounted to a food tax that would raise of the cost of living. The Cobden Club continued to push back against Chamberlain's protectionist measures, accusing him of making promises that he would not be able to keep. In one of its published tracts the Cobden Club commented that, "Mr. Chamberlain... seems to be anxious to ride two horses at the same time," arguing that he advocated for tariffs, which

\footnotetext{
${ }^{76}$ Howe, Free Trade, 230.

${ }^{77}$ Frank McDonough, The Conservative Party and Anglo-German Relations, 1905-1914 (London: Palgrave MacMillan, 2007), 115.

${ }^{78}$ Ibid., 116.

${ }^{79}$ Tariff Reform League, "Monthly Notes on Tariff Reform,” 1, no. 15 (July 1911): 4.

${ }^{80}$ Howe, Free Trade, 232.
} 
would raise the price of goods, while still seeking to "disarm the opposition of consumers by persuading them that they will not feel the burden of the tax," arguing that taxes would be an inevitability of such a proposition. ${ }^{81}$ As such, Cobden Club members continued to be strident defenders of free trade policies.

Other critics worried about how preferential system would harm world trade. Chamberlain's ideas were harmful, they argued, because Britain was also dependent on foreign markets and risking access to foreign supplies was considered to be too risky. ${ }^{82}$ They also pointed out that Britain relied on global, not imperial markets, as the destination for capital and manufactured goods. ${ }^{83}$ The hope of revitalizing British manufacturing through tariffs was also questioned by the Dominions, who were in the processes of creating their own secondary industries, and as such the turn to tariff reform in Britain also led to national buying campaigns in Australia and South Africa aimed at encouraging the purchasing of their own domestic goods, a move that would be repeated, as will be shown, decades later. ${ }^{84}$ Thus, the debates surrounding the issues of trade and international markets continued to be contentious.

Posters of the period also illustrate how debates on trade continued to manifest through the focus on food. In the TRL's propaganda, the issue of cheap food remained a central one. In one illustration, a boy is depicted going to buy bread in the "Free Trade Stores" but is told by the shopkeeper that the price has increased (Fig. 4). All the while,

${ }^{81}$ The Cobden Club. Fact Versus Fiction: The Cobden Club's Reply on Mr. Chamberlain (Cassel \& Company: London, 1904), 52.

82 Thackeray, Forging a British World of Trade, 33.

${ }^{83}$ Ibid.

84 Ibid., 19. 
the shelves are stocked with food from Germany, the U.S., Holland, and France rather than home producers. The sign in front of the counter represented the broken promises of the Liberal's 1906 victory, the promise of cheap food. Liberals, on the other hand, also used the motif of the store in their own propaganda. In a Liberal poster depicting the differences between an economy of free trade and one of protectionism, the free trade shop is filled with customers seeking its cheap goods, while the protectionist shop, crippled by high prices, remains empty (Fig. 5). Both sides sought popular support based on the idea that their victory would mean cheaper goods, while the opposition's would raise prices.

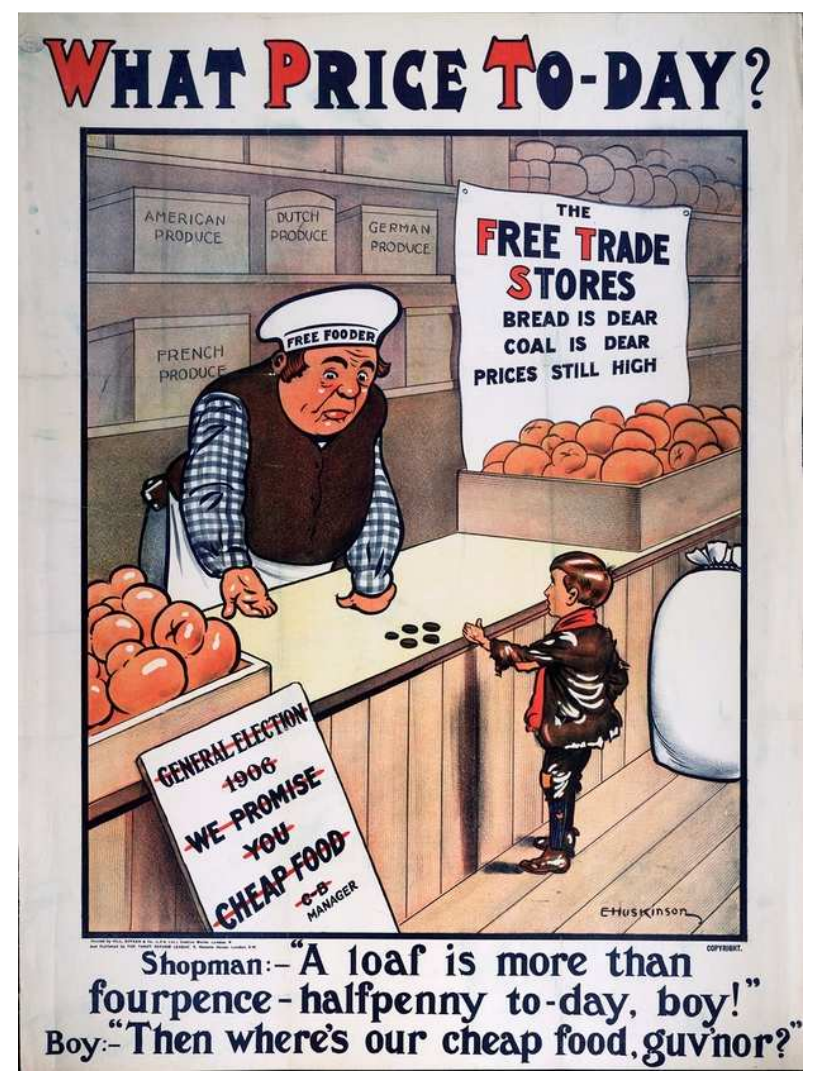

Figure 4. Tariff Reform League poster. E. Huskinson, What Price Today? Lithograph. London School of Economics Digital Library. London, England https://digital.library.1se.ac.uk/objects/lse:nuh672lez. 


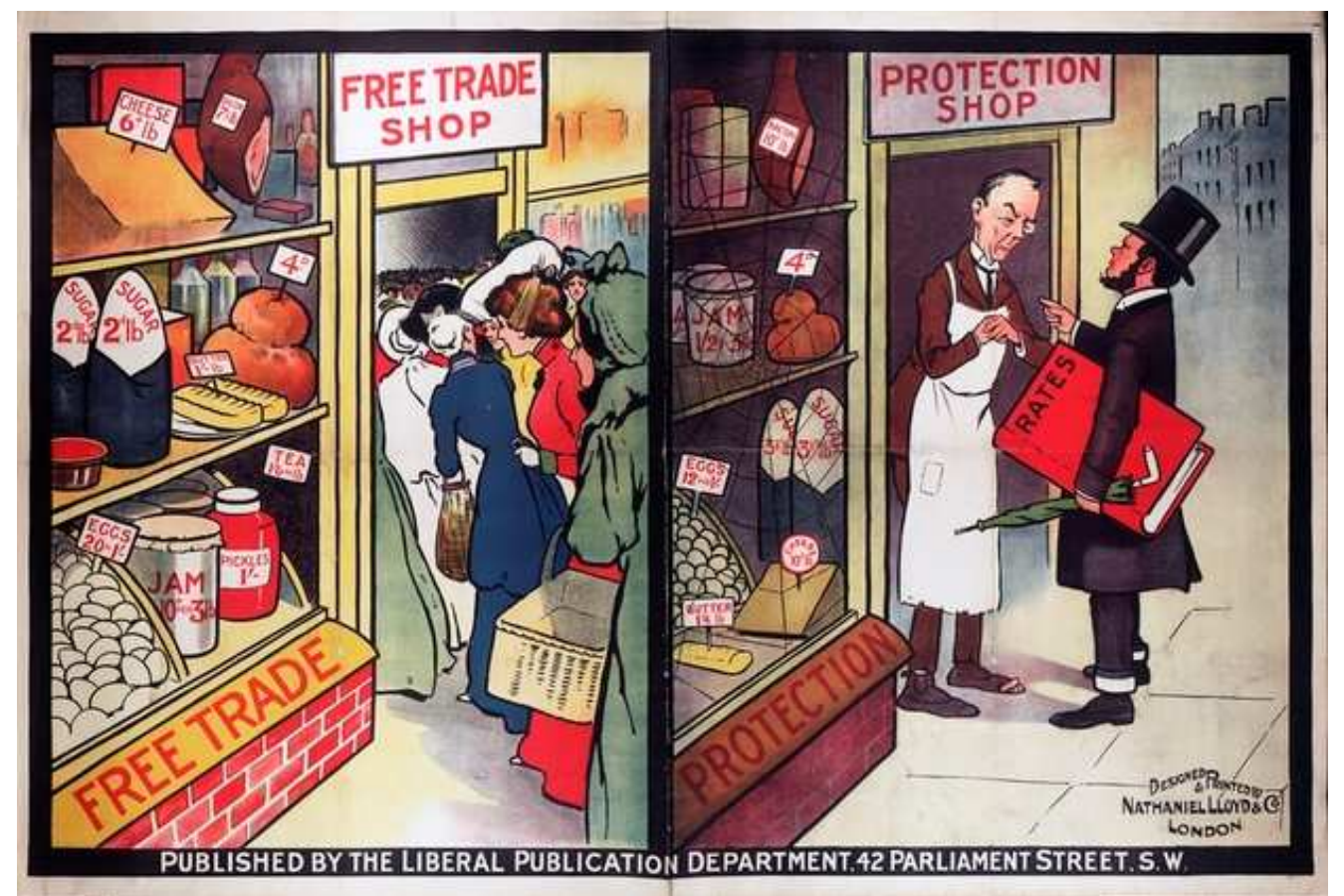

Figure 5. Liberal Party poster, Free Trade and Protection, London School of Economics Digital Library. London, England https://digital.library.1se.ac.uk/objects/lse:gev962ban

Tariff policy proved just as divisive within parties as it was between them. In January 1913 the Conservative Party, led by Bonar Law, agreed to forgo plans for introducing a system of imperial preference due to its contentious nature. This put tariff reform on the back burner for several years and led to a further split on the right in 1917, between the "imperial activist" wings that stressed the need for preference and "gradual Unionists" who saw pursuing tariff reform as a political liability and instead privileged allegiance to the stability of the Conservative Party. ${ }^{85}$ The debate over imperial

${ }^{85}$ Leo Amery, who would play a major role in the EMB's formation represented a
position characteristic of the former, while others like Joseph Chamberlain's son Austen
would represent the latter. See Thackeray, “The Crisis of the Tariff Reform League and
the Division of 'Radical Conservatism,' c. 1913-1922." History 91, no. 301 (2006): 53-4. 
preference continued throughout much of the Edwardian period. The post-WWI period would lead to new political experimentations in an attempt to win popular support for preference.

\section{$\underline{\text { Post-WWI Internationalism }}$}

The First World War necessitated new levels of government action, leading to new bureaucratic roles, which bridged the divide between the economic and political arenas. The initial reluctance of the British government to institute rationing during WWI meant rising food prices and food shortages for consumers, especially during the German U-boat campaigns. ${ }^{86}$ It also brought home the extent to which Britain relied on foreign food imports. Discontent led to the creation of the Ministry of Food in 1917, which helped to ensure that the public received adequate food supplies. The War had also led to the first fracturing of Britain's free trade policy with the institution of the McKenna Duties, which were taxes imposed on luxury goods to raise revenues for the war and help conserve shipping space ${ }^{87}$ Shortly after the War, similar measures such as the Safeguarding of Industries Act of 1921 raised duties on products that had played strategic role in the fighting of the war. This shift in trade policy was also envisioned as a means of providing additional revenue to offset war debt. ${ }^{88}$ Duties were increasingly levied on imported goods, while those from the Empire were granted preferential rates.

\footnotetext{
${ }^{86}$ Guerney, The Making of Consumer Culture, 130.

${ }^{87}$ Charles P. Kindleberger, Historical Economic: Art or Science (Berkeley: University of California Press, 1990), 127.

${ }^{88}$ W.R. Garside, "Party Politics, Political Economy and British Protectionism, 19191932," History 83, no. 269 (January 1998), 49.
} 
The formation of the League of Nations was another outgrowth of WWI. The League of Nations came into being in the wake of the First World War as an international organization that could help to manage international security. At the Paris Peace Conference in 1919, U.S. President Woodrow Wilson's “Fourteen Points” were redrafted and a Covenant, the governing charter, was drawn in collaboration with the Allied Powers. The Covenant laid out measures for defense such as disarmament and methods for settling international disputes. ${ }^{89}$ It also included treaties on social issues, the affirmation of political rights of minorities in the Eastern Europe and the Balkans, and framework for the administration of the former territories of the Central Powers. It served as the site of knowledge gathering in the realm of finance and economics and served as the "theatre for international publicity and norm-making," where groups, nations, and organizations could find an international stage for their grievances. ${ }^{90}$ However, the goal of internationalism did not manifest for everyone. The same justifications for expansion in the nineteenth century were central to the new internationalist system, which remained "a firmly European construct." 91 The new international law still contained preconceptions about "civilized" society and who might participate in the new international political order. ${ }^{92}$ This went hand in hand with the basic assumptions that

${ }^{89}$ Simon Jackson and Alanna O'Malley, "Rocking on its Hinges? The League of Nations, the United Nations and the New History of Internationalism in the Twentieth Century," in The Institution of International Order: From League of Nations to the United Nations, ed. Simon Jackson and Alanna O’ Malley (London; New York: Routledge, 2018), 7. ${ }^{90}$ Ibid.

${ }^{91}$ Daniel Gorman, The Emergence of International Society in the 1920's (Cambridge: Cambridge University Press, 2012), 8.

${ }^{92}$ The push for Egyptian, Korean, Indian and Chinese nationalism illustrated that ideas about self-determination did not often coincide with their European counterparts. Areas of Asia, Latin America, and the colonial world were largely left out of the new world 
underlined the League's foundations, that homogenous societies held the best possibility for peace and order. ${ }^{93}$

Eventually all British Dominions, with the exception of Newfoundland, became members of the League. The signatures of the Dominions on the Treaty of Versailles served as a symbol of their increasing autonomy ${ }^{94}$ Membership to the League was also sought out by Irish nationalists. After the signing of the Anglo-Irish Treaty, establishing the Irish Free State as a Dominion in 1922, the Treaty was registered with the League as a symbol of equality with other states. It helped to affirm that agreements between Commonwealth countries carried the same weight as those between other nations, signaling their increasingly autonomous status. ${ }^{95}$

However, the economic interdependence of Britain and the Dominions also meant their continued cooperation was essential, even with the increasing sovereignty of the Dominions on the international stage. It also gave imperialists the motivation to find new ways of maintaining the partnership that had carried the Empire through the War years. The First World War did not put an end to the push for imperial union. The market that the British Empire provided, the investments financed by London, and the protection provided by Royal Navy all meant incentive for the Dominions to stay within the realm

order. See Erez Manela, The Wilsonian Moment (Oxford: Oxford University Press, 2007; Mark Mazower, "An International Civilization? Empire, Internationalism and the Crisis of the Mid-Twentieth Century," International Affairs 82, no. 3 (2006): 565.

93 Thomas and Thompson, "Empire and Globalization," 151.

94 Jaroslav Valkoun, "Great Britain, the Dominions, and the Paris Peace Conference," West Bohemian Historical Review 4, no. 2 (2014): 160.

${ }^{95}$ Gerard Keown, First of the Small Nations: The Beginning of Irish Foreign Policy in the Interwar Years (Oxford: Oxford University Press, 2016), 105; 133. 
of the Empire. Few in the Dominions wanted to break all ties with Britain. ${ }^{96}$ Additionally, the Dominions provided markets for British manufactures so the need to maintain imperial relations was paramount. The Dominions provided 50 percent of Empire imports between 1909 and 1913 and received 54.6 percent of exports to the Empire. ${ }^{97}$ Britain and the Dominions continued to be economically dependent on each other.

In a series of lectures, historian Alfred Zimmern would call the new phase of imperial relations, a time of managing an increasingly tenuous national, imperial, and international landscape, the "Third British Empire." He noted the difficult predicament that the Empire now faced in comparison to its former influence. "For a century or more we "held the world in fee,"” he observed, "Vestiges of this supremacy still remain but on the whole we have now to face a fare more equal competition and, in many cases, as we have discerned to our cost, a competition in which the dice are heavily loaded against us." 98 The Third British Empire, envisioned as a mutually cooperative "Commonwealth of Nations," served as new model for integrating independent nations into the fold, while still maintaining imperial ambitions. The recasting of the British Empire as a voluntary political cooperative meant rethinking imperialism and how the Empire increasingly fit into a world that was more uncertain and more critical of its ambitions.

\footnotetext{
96 Thompson, Imperial Britain, 174.

${ }^{97}$ Dilley, "The Economics of Empire," 103.

${ }^{98}$ Alfred Zimmern, The Third British Empire: Being a Course of Lectures Delivered at Columbia University, New York (Westport: Greenwood, 1972), 62-64.
} 


\section{The Post-War Slump}

Post-war decline helped to reinvigorate the enduring debate about tariff reform, as parties and interest groups fought over the best course of action for economic relief. In Britain, heavy industry continued to remain depressed - especially in the coal, iron, steel, engineering and textile industries. Conservatives and business interests were both drivers of the move toward tariff reform. It was considered to be a necessary solution for the one million workers that remained unemployed, and the thirty percent fall in GDP between 1920 and $1924 .{ }^{99}$ Conservatives blamed dumping and unfair competition, but they were also aware of other problems such as underinvestment, inefficiency, and overcapacity in production. It was hoped that protection would give shelter to domestic industries and allow them to begin rationalization and modernizing efforts. ${ }^{100}$ Many began to push for an imperial solution that would make the Empire more self-sufficient and less dependent on expensive imports.

The Labour Party also emerged from the War as a growing force. Both Liberals and Labour denounced Conservatives for trying to impose tariffs. The Labour Party depended on Liberal support in Parliament, and both parties remained supportive of free trade policies. ${ }^{101}$ The Labour Party advocated for a greater state role and attested to the benefits of socialism as a counterweight to the defects of capitalism. ${ }^{102}$ Trade union

${ }^{99}$ P. Lloyd Greame. National Archives. Cabinet Papers. "Proposals for Financial Assistance to Accelerate the Development of Imperial Resources," (August 2, 1923): 292.

${ }^{100}$ Ibid., 286; 293.

101 Garside, "Party Politics," 51.

102 Stuart Ball, "The Conservative Party, The Role of the State and the Politics of Protection, c. 1918-1932," Journal of the Historical Association 96, no. 323 (July 2011), 28 
membership grew from 4 million in 1914 to 8 million in $1920 .{ }^{103}$ Given the economic downturn and high unemployment rate, many employers looked to cost-cutting "rationalization" measures to recover lost profits. The General Strike in May 1926 of over 1.5 million workers reflected ongoing discord. The Trade Disputes and Trade Union Act of the following year outlawed "sympathy strikes" and other forms of industrial action. Opposition to his legislation drew the Labour Party and unions closer together and created further political tensions at home.

The expansion of the franchise after WWI also enlarged the electorate to include the and women over aged thirty, which would expand to universal suffrage in 1928. This also led to new efforts to appeal to an increasing diverse electorate. In 1923, the Liberal and the Labour Parties made appeals to the 8 million newly-enfranchised women, arguing that housewives would suffer due to increased food prices if Conservatives won. ${ }^{104}$ The Conservatives loss led them to more firmly appeal to female voters and issues that affected their interests. The expansion of political constituencies would also influence later attempts by the EMB to appeal directly to larger demographics of imperial consumers.

Business and political interests increasingly looked to the Empire and the creation of an empire market as a solution to post-war decline. During the 1923 Imperial Conference, MacKenzie King and Stanley Bruce, Prime Minsters to Canada and Australia respectively, emphasized that empire development was a matter of "men,

103 H. A. Clegg, A History of British Trade Unions Since 1889. Vol. 2: 1911-33 (Oxford: Oxford University Press, 1985), 570.

${ }^{104}$ Martin Pugh, “Women, Food and Politics 1880 - 1930," History Today 41, no. 3 (March 1991): 19. 
money, and markets," the Dominions would benefit from emigration and investment from Britain and in return the Britain benefitted from the enlarged market for manufactures. ${ }^{105}$ At the Conference, it was suggested that Britain should move to implement imperial preference, setting up a system of tariffs with preference to imports from the Empire. Cabinet recommendations to the Prime Minister during the Conference acknowledged that export trade of that year trailed behind 1913 levels by $31 \%$. P. Lloyd Graeme noted that with the Russian Revolution, the fall of the German Empire, production reduction in other countries, the uncertain future of new states, and emerging protectionist legislation it was likely that European trade would no longer be "anything like normal proportion;" thus, it was imperative that Britain shift its focus to the Empire. ${ }^{106}$ Dominion prime ministers called on Britain to enact preference, and

\footnotetext{
${ }^{105}$ The Dominions had long regulated immigration, with a preference for British and European immigrants, restricting those from other regions, such as those from China and India. At the 1907 Colonial Conference, the Prime Minister of Australia, Alfred Deacon, remarked that he was "determined to have a white Australia," and "keep it white," while New Zealand Premier Joseph Ward asserted that New Zealand "is a white man's country, and intends to remain a white man's country." Both assertions reaffirm the racial demarcation that existed between the conceptualized Anglosphere and the rest of the Empire. See Alison Bashford, "Immigration Restriction: Rethinking Period and Place from Settler Colonies to Postcolonial Nations," Journal of Global History 9, no. 1 (2014): 26-48 and Mark R. Frost, "Imperial Citizenship or Else: Liberal Ideals and the India Unmaking of Empire, 1890-1919," Journal of Imperial and Commonwealth History 46, no. 5 (2018): 845-873.

106 The National Archives Website. Discovery: Records of the Cabinet Office: CAB 24/158. Proposals for Financial Assistance to Accelerate the Development of Imperial Resources. Joint Memorandum by the Secretary of State for the Colonies and the President of the Board of Trade. February 8, 1923. Available at http://filestore.nationalarchives.gov.uk/pdfs/small/cab-24-158-CP-90.pdf
} 
Conservatives were afraid that if they did not respond, it would lead to a rift with the Empire. ${ }^{107}$

The political campaign of Conservative Stanley Baldwin was centered on the push for such legislation. But the continuing depression in agriculture led to debate about how protectionism would affect food prices. Baldwin, aware of the contested nature of imperial preference, made a promise not to enact new protective duties except in special circumstances. However, the belief that such a move would raise food prices contributed to Conservative losses in the elections of 1923 . The issue of food continued to be a central concern among consumers, reflecting their longstanding aversion to any tariff measures that might raise food prices. Even though many were aware of the dire economic situation, the public of the 1920s had more reservations about tariff reform and any form of food tax.

When the Conservatives came back to power in November, 1924, with Baldwin as Prime Minister, they were aware that Britain's traditional commitment to free trade and the desire for cheap food imports still made imperial preference legislation politically controversial. Instead, they sought a systemic compromise; pushing for a system of imperial preference through influence rather than legislation. Leo Amery, who served as Secretary of State for the Dominions and Colonies, and Conservative imperialists argued that the future of Britain in the "new era" was heavily dependent on developing and promoting trade with its empire, and enacting imperial preference became his main

${ }^{107}$ Ball, "The Conservative Party," 295. 
preoccupation. ${ }^{108}$ However, new approaches would need to be employed in enacting such goals considering the longstanding fear of food taxes among consumers. If preference could not be enacted through legal channels, the masses would have to be persuaded.

\section{The Formation of the Empire Marketing Board}

The failure to enact preferential tariffs in 1924 had frustrated both Conservatives and the Dominions, who had hoped to reach a more favorable trade agreement. Dominions had extended preferences to Britain but, as Britain retained its free trade policy, Dominions faced steeper competition in the British market. Freetrade skeptic Phillip Cunliffe-Lister, who was President of the Board of Trade, brought forward a compromise that was accepted with reluctance by Amery and the Dominions but that came as a relief to Prime Minister Baldwin and the Cabinet. ${ }^{109}$ Instead of the preferential duties promised by the government, an equivalent of taxpayer money would be set aside to promote the sale of Empire goods in Britain. The idea was also favored by free trader Winston Churchill, who was head of the Treasury, for the nontariff nature of the idea and limited funds that it would require. Churchill assured Baldwin that it would appeal both to those that disapproved of preference and those who wanted to maintain imperial obligations. ${ }^{110}$ The initiative was approved by

\footnotetext{
${ }^{108}$ L.S. Amery, My Political Life Volume II (London: Hutchinson, 1953), 291; III: 19, 24. ${ }^{109}$ Stephen Constantine, Buy and Build: The Advertising Posters of the Empire Marketing Board (London: HMSO, 1986), 3.

${ }^{110}$ Robert Self, "Control and the Empire Marketing Board: The Rise and Fall of NonTariff Preference in Britain, 1924-1933," Twentieth Century British History 5, no. 2 (1994): 161.
} 
Baldwin, and Amery spearheaded the establishment of a government department to administer the Empire Marketing fund.

The Board of Trade established an ad hoc Interdepartmental Committee to explore how the organization would be set up. Both Amery and Churchill realized that relying on the Treasury for resources would be difficult because of its unwillingness to use public funds for imperial purposes. ${ }^{111}$ The Interdepartmental Committee raised the question of how funds would be allotted, if it would be given as a grant, in which unspent money could be retained, or by an annual vote in Parliament, where surplus funds would be returned to the Treasury. Amery was in favor of the former and Churchill preferred the latter. The decision was made to fund the EMB as a grant, a move which Churchill disagreed with and which caused continued tensions between the Board and the Treasury. Officially, the EMB served in an advisory capacity under Amery, as Secretary of State, but because he was chairman of the Board it also had executive authority, giving the Board a relatively unique level of autonomy.

The Empire Marketing Board was officially established in May of 1926, serving as part of the official mechanism of state. It was initially granted an annual operating budget of $£ 1$ million for research, marketing, and publicity - serving as a rough cash equivalent of the preferential duties that had previously been promised, but not realized, by Conservatives. The main Board was made up of twenty members, including cross-party representation from the Liberal and Labour parties. It also included other prominent officials such as the Under-Secretary of State, the Financial

${ }^{111}$ Ibid., 161. 
Secretary to the Treasury, the Secretary to the Ministry of Agriculture and Trade, the Comptroller-General of the Department of Overseas Trade, and representatives from the Dominions as well as India and the colonies. The main Board was responsible for reviewing the recommendations of the various committees and subcommittees, providing the final authorization for proposed recommendations, as well as the final allotment of funds for current and future endeavors. Other Committees included those on Research, Marketing, and Publicity- reflecting the Board's three principal aims.

The Board was aware early on of the considerable challenges that it faced. By 1926, imports from the Empire only constituted 30 percent of total imports. Less than half of its grain and dairy, and a quarter of meat and fruit came from the Empire. ${ }^{112}$ Consumer ignorance also played a role, as Amery recalled having to convince some shoppers and shopkeepers that California canned fruit was not a product from the Empire. ${ }^{113}$ It also faced a relative lack of precedent in the governmental sector. During the First World War, The Ministry of Information had made attempts at propaganda and advertising, but it only lasted for the duration of the War. Smaller government offices like the armed services and the Foreign Office had continued to advertise or engage in propaganda efforts but they were relatively small in scale. The aims of the Board were novel and outside the typical work of government agencies. It was for this reason that the EMB would turn to the private sector to help advise them on research, marketing and publicity strategies.

Amery would remark that the aim of the EMB was to reimagine the Empire as

${ }^{112}$ Constantine, Buy and Build, 3.

${ }^{113}$ Ibid. 
a collaborative undertaking, rather than the connotations of Empire as synonymous with conquest and domination. He would recount that the EMB was acting, "not to glorify the power or the wealth of the Empire," rather, "what we wanted to sell was the idea of Empire production and purchase; of the Empire as a co-operative venture. Above all, as a co-operative venture between living persons interested in each other's work and each other's welfare."114 Amery affirmed that the Board was concerned with projecting new ideas about the ways that Empire could function within the new international context. The EMB promoted the unified ideal of Commonwealth as an international venture in which the Dominions partners would share in "joint task of Empire," the creation of a wider economic union. ${ }^{115}$

Stephen Tallents, who was chosen to be the Secretary of the Board and who ran most of its day-to-day operations, proved a central part of the EMB and its work.

Previously, Tallents had been employed in the Civil Service, helping to initiate food rationing for the Ministry of Food during WWI, then working on postwar relief efforts in the Baltic. He also served as Imperial Secretary to Northern Ireland and as Secretary to the Cabinet Committee managing the General Strike, all experiences that made him aware of the need to manage public opinion. ${ }^{116}$ Tallents recognized the importance of using publicity as a tool to inform, explain government activities, and persuade the masses. He would eventually go on to become the founder and President of the

\footnotetext{
${ }^{114}$ Amery, My Political Life, 352.

115 Ibid., 12; 36.

${ }^{116}$ Scott Anthony, Public Relations and the Making of Modern Britain: Stephen Tallents and the Birth of a Progressive Media Profession (Manchester: Manchester University Press, 2011), 5-6.
} 
Institute of Public Relations, helping to facilitate the expansion of public relations within government service. He was described by his colleague as having an, "imagination completely unfettered by red tape." ${ }^{117}$ It was that creativity that encouraged the EMB to utilize new channels to project its message, such as art, film, radio, and other publicity.

The formation of the EMB thus began at a time when the role of the state was shifting. This meant a reevaluation of the ways that government functioned, as the state became more concerned with its public perception. ${ }^{118}$ The emergence of the EMB and its marketing aims were formed within the context of a population that was more skeptical about government regulation of the mechanisms of the market. Politically engaged "citizen consumers" had emerged as a powerful interest group, combining both conscientious consumption and political activism. Arguments against state intervention were based on the belief that free trade sheltered commerce from averse political interests and that state intervention might hurt the interest of consumers. ${ }^{119}$ Free trade had opened Britain's markets to cheap products of all kinds and the cost of food continued to be a primary concern for many consumers. ${ }^{120}$ The EMB had to endeavor into new realms to

117 Gervais Huxley, Both Hands (London: Chatto \& Windus, 1970), 129.

118 Jacquie L'Etang, "State Propaganda, and Bureaucratic Intelligence: The Creation of Public Relations in the $20^{\text {th }}$ Century," Public Relations Review 24, no. 4 (1998): 413-441. ${ }^{119}$ Patricia Maclachlan and Frank Trentmann, "Civilizing Markets: Traditions of Consumer Politics in Twentieth-Century Britain, Japan and the United States," in Markets in a Historical Context: Ideas and Politics in the Modern World, ed. Mark Bevir and Frank Trentmann (Cambridge: Cambridge University Press, 2004), 171-173. ${ }^{120}$ Though accounting for 3 percent of the world population by 1930, Britain took in 99 percent of the world's exported bacon and ham, 96 percent of eggs, 59 percent of beef, 46 percent of cheese, and 28 percent of the wheat. In addition, by the 1930's seventy percent of Britain's canned goods came from abroad. It was also a major importer of produce. It 
convince a diverse array of consumers that buying from the Empire would help not only their families at home but their larger imperial one as well.

Tallents, would note that, "If we are to win their custom, we must first win their minds," indicating that in order for the EMB to encourage consumers to buy more products from the Empire, it had to first show them why doing so was so imperative.

${ }^{121}$ Similarly, F.L. McDougall, the Australian representative to the Board, wrote that the goal of the EMB was to, "foster...an Empire consciousness in the mind of the British people." ${ }^{122}$ Considering the long debate between free trade and tariff reform and the economic realities of the post-war period this was not a simple task. The attempt at manufacturing a consumer society that would demand imperial products, and, thus, reinvigorate the stalling economy meant the creation of new markets and mindsets as both "a single family and a single economy." 123 The use of new technologies and marketing mechanisms to promote voluntary preference was seen as an important resource for maintaining the strength and unity of the Empire. It was with this aim in mind that the EMB went to work in 1926.

\section{$\underline{\text { Conclusion }}$}

was this reliance on foreign goods that the EMB was trying to challenge. Oddy, From Plane Fair to Fusion Food, 96-97.

${ }^{121}$ Stephen Tallents, "The Projection of England," (1932) Reprinted in Scott Anthony, Public Relations and the Making of Modern Britain: Stephen Tallents and the Birth of a Progressive Media Profession (Manchester: Manchester University Press, 2012), 35.

${ }^{122}$ F. L. McDougall, "The Empire Marketing Board and Empire Economic Affairs," The Economic Record 4 (February, 1928): 141.

${ }^{123}$ Murton, "John Bull and Sons," 242. 
Food played a central role in the public's commitment to free trade, and it played a crucial role in the formation of the EMB. Throughout the decades, the fight over tariffs was linked to the issue of food prices and the welfare of shoppers. Political interests were able to politicize the issue of hunger over time to appeal to consumer interests. By implementing free trade politicians were able to placate classes, who were all able to benefit from the import of inexpensive goods, though the policy did not go unchallenged. WWI and the subsequent economic downturn that resulted, however, began to erode the economic and political separation that free traders had hoped to maintain as the state expanded into new roles. The interest in turning to the Empire as an economic solution to domestic decline emerged in the later nineteenth century but made a comeback in the 1920 's, as the rationalization of imperial resources came to be viewed as a solution to post-war economic decline. In the age of interwar internationalism, the state sought to conceptualize and project the Empire as a modified, benign "Commonwealth," a voluntary alliance between mutually cooperative states. The allegiance to free trade was gradually eroded over the course of the decades, but it still proved to be a primary concern for domestic consumers. Conservatives recognized that any attempt to implement imperial preferences on goods would be unpopular with consumers, who now held more of a stake in political affairs. The attempt to create a voluntary system by appealing directly to consumers, illustrates their central role in the attempt to remake the Empire after WWI.

The modern technologies used by the EMB to reframe the imperial debate scientific and economic investigation and the use of a host of new media - helped to push forward this new vision to consumers. Within the context of the 1920's, this meant 
reframing the narrative of tariff reform in the language of international cooperation that would appeal to shoppers and tie together increasingly diverse imperial subjects. The creation of an empire market, both real and imagined, required the help of a diverse array of experts who were given the task of selling the new vision of Empire to hesitant or ignorant shoppers. The tenuous economic situation that Britain found itself in after the War, made the effort all the more urgent. The first problem that the EMB sought to tackle, and the one that was the focus of much of its resources, was the utilization of science to procure imperial resources for domestic consumption. Its use of science will be the subject on the following chapter. 


\section{Chapter Two}

Cultivating Commerce: Empire, Experts, and Networks of Science

When a Briton sat down to breakfast in 1926, there was a good chance that their meal came from sources that spanned the globe. The "full English," likely consisted of bread made from North American wheat. It also might have included butter, bacon, and eggs that came from Denmark, tea from India or, perhaps, coffee from Costa Rica served with Cuban sugar. For those that could afford them, the vogue for fruits like oranges from Spain or bananas from Columbia also filled out this expansive food web. ${ }^{124}$ Agricultural geneticist Edward East remarked in the 1920s that," Our daily life is a trip around the world, yet the wonder of it gives not a single thrill." ${ }^{125}$ Free trade had facilitated the influx of goods from around the world, and it reflected the influence of both economic and ecological forces.

The EMB emphasized the novel changes to the world food system that had recently taken place. Through its advertising, the Board illustrated to consumers that through the technological and scientific advancement of the preceding decades, a phenomenal food transformation had occurred: "Your grandfathers ate little but the produce of the fields around them," it explained, but today, "The development of Empire lands overseas, the increasing speed of ships and railways, and the discoveries of cold storage have brought to the humblest households in our great towns the produce of distant

\footnotetext{
${ }^{124}$ According the EMB's commodity reports, published in 1932, each country represented the largest imports of each given product.

${ }^{125}$ Edward East, Mankind at the Crossroads (New York: Charles Scribner \& Cons, 1924), 64.
} 
territories and various climates." ${ }^{126}$ Technology and science had facilitated the worldwide transport of food. The problem with such an assertion, however, was that though foods of many "distant territories" came to Britain, that did not mean that they were all sourced from Empire producers. British food came from all over the world. The Board's main concern in getting consumers to "Buy Empire" was the fact that consumption in Britain relied heavily on non-Empire goods.

In his survey of tropical agriculture commissioned by the Board, C.A. Barber of the School of Agriculture at Cambridge noted that, "The luxuries of yesterday have become the necessities of the mases of to-day, with a demand for lower prices all round." ${ }^{127}$ Demand for products like cacao, rubber, sugar, and coffee had increased at a much higher rate than other staple crops like wheat. This demand necessitated the procurement of goods at cheap prices to satisfy consumers. The use of science and technology to further development in the Empire were influenced by the demands of British consumers and their desires for cheap commodities.

In order to reorient trade away from foreign producers, the EMB sought to encourage the cultivation of goods and raw materials from within the Empire. The EMB envisioned an expansive imperial "market garden" from which British consumers might shop, helping the entirety of the Empire in doing so. ${ }^{128}$ Creating new sources of

\footnotetext{
${ }^{126}$ James Murton, "John Bull and Sons," 232.

${ }^{127}$ C.A. Barber, Tropical Agricultural Research in the Empire: With Special Reference to Cacao, Sugar Cane, Cotton and Palms (London: HMSO, 1927), 17.

${ }^{128}$ In its posters, the EMB referred to Empire countries as "market gardens." For example, depictions of sugar farmers in Mauritius were juxtaposed with the caption, "The market garden of the tropics - Mauritius sugar."
} 
production necessitated new efforts to rationalize the development of the "gardens" of the Empire. As James Beattie has emphasized, controlling the natural world was paramount to capitalizing on its resources, as "accessing and controlling environments underpinned British imperialism." ${ }^{129}$ Board officials affirmed that by making the transportation of perishable foods easier, less expensive and consistent, British markets could be opened up to Empire producers, which could prove even more valuable than tariffs. ${ }^{130}$ However, their push to find alternative resources also reaffirmed assumptions about hierarchy within the Empire. Developing the imperial "gardens" largely privileged the interests of the metropole at the expense of colonies, which were looked to largely for their economic potential in what commodities they might provide domestic consumers. As such, many of the scientific studies that were funded by the EMB were efforts to increase the production of primary goods within the Empire, which reaffirmed the hierarchy between British interests and the rest of the Empire.

To facilitate the production of imperial resources that the public demanded, scientific experts were called upon to aid their cultivation, as hurdles to development ranging from adverse weather conditions and harsh soils, to crop diseases and pests - all challenged attempts at agricultural development. The packing and shipping of goods similarly presented a host of challenges. Such difficulties were a motivating factor for why the EMB's recruitment of scientific expertise became a principal aim in reorienting trade toward the Empire. The difficulties involved with establishing and expanding the

\footnotetext{
${ }^{129}$ James Beattie, "Recent Themes in Environmental History," History Compass 10, no. 2 (2012): 129.

${ }^{130}$ Worboys, "British Colonial Science Policy," 106.
} 
growth of consumer goods in the Empire encouraged the expansion and fortification of networks between government interests and scientific experts.

\section{$\underline{\text { Empire Development }}$}

The EMB's interest in development reflected a long alliance between science and empire. From the earliest explorations of acquired territories and the study of natural history, scientific research was often intertwined with colonial ambitions. The transfer of plants and animals across wide expanses helped to create new ecological systems, ripe for study. ${ }^{131}$ The $19^{\text {th }}$ century improvement of infrastructure such as ports, railways, roads, and irrigation systems also meant more resources for both economic and scientific advancement. ${ }^{132}$ Such developments were often conceptualized as an indicator of progress and a means of improving the lives of indigenous populations. ${ }^{133}$ The reliance of the West on tropical products provided the impetus to cultivate increasing numbers for export. Colonial powers sought to use science and technology to increase production and make agricultural products more affordable for the public, as science and consumer demands were often interconnected. ${ }^{134}$

\footnotetext{
${ }^{131}$ Alfred W. Crosby, Ecological Imperialism: The Biological Expansion of Europe, 9001900 (Cambridge: Cambridge University Press, 1986), 254-5.

${ }^{132}$ Richard Drayton, Nature's Government: Science, Imperial Britain, and the 'Improvement' of the World (New Haven: Yale University Press, 2000), 255-56.

${ }^{133}$ Michal Adas, Machines as the Measure of Men: Science, Technology, and Ideologies of Western Dominance (Ithaca: Cornell, 1986); 196, 224.

${ }^{134}$ David Headrick, The Tentacles of Progress: Technology Transfer in the Age of Imperialism, 1850-1940 (Oxford: Oxford University Press, 1988), 6.
} 
In the nineteenth century, the reliance on plantation systems for the growth of Empire commodities had illustrated the weaknesses of monoculture. Plantation systems had been established throughout the Empire in places such as Ceylon, Malaya, the West Indies, and tropical Africa. However, such specialized systems were often vulnerable to natural and economic fluctuations. Changes in the world market and ecological concerns such as degradation of soil due to environmental stresses were also some of the issues at hand. The erosion of the coffee industry in Ceylon and the sugar industry in the West Indies were indicative of the overreliance. ${ }^{135}$ This led to more efforts at diversifying crops for export as well as rationalizing agriculture to increase the efficiency of production.

Tariff reformer Joseph Chamberlain, during his time as Secretary of State, had illustrated that the value of Empire trade was closely linked to science and technology. In an 1895 lecture, he affirmed that, "It is not enough to occupy certain great spaces of the world's surface, unless you can make the best of them, unless you are willing to develop them. We are landlords of a great estate; it is the duty of the landlord to develop his estate." 136 The "great estate" that was the Empire increasingly came to be seen as a resource that could be tapped through modern science - as a source and market for important commodities. The Colonial Office also began to draw upon established networks such as those provided by the Royal Botanic Gardens at Kew and the Imperial Institute. By 1914, agricultural experts were stationed in most of the colonial territories. ${ }^{137}$

\footnotetext{
135 Joseph Morgan Hodge, Triumph of the Expert: Agrarian Doctrines of Development and the Legacies of British Colonialism (Athens: Ohio University Press, 2007), 56-57. 136 "Mr. Chamberlain on Trade," The Times, April 1, 1895, 11.

${ }^{137}$ Hodge, Triumph of the Expert, 87.
} 
It was with the First World War that the call for research funding was heeded in greater earnest. In July 1915, the Scientific Advisory Council was established and twelve months later it would become the Department of Scientific and Industrial Research (DSIR). During the same year, similar research advisory councils were also established in Australia and Canada. Research networks had been mobilizing throughout the British academic world since the 1880 's, but the War helped to organize scholars from Allied countries to an even greater extent. ${ }^{138}$ Bureaucratic rationalization helped to encourage empirical assessments of colonial conditions, classifying both human and natural resources. ${ }^{139}$ This helped to establish greater confluence between technical expertise and the bureaucracy of state.

International organizations that emerged after the War, such as the League of Nations, also helped to legitimate the further development of colonial resources by portraying colonial powers as "modern, progressive, civilizing polities," reconciling the imperial with the international. ${ }^{140}$ The promotion of science and colonial development continued to be justified based on its perceived humanitarian potential, as a means of peacekeeping and fostering international cooperation. ${ }^{141}$ Article 22 of the League

138 Tamson Pietsch, Empire of Scholars: Universities, Networks and the British Academic World 1850-1939 (Manchester: Manchester University Press, 2013), 130-139.

${ }^{139}$ Miguel Bandeira Jeronimo, "A League of Empires: Imperial Political Imagination and Interwar Internationalisms," in Internationalism, Imperialism and the Formation of the Contemporary World, ed. Miguel Bandeira Jeronimo and Jose Pedro Montiero (Cham: Palgrave Macmillan, 2018), 104-105.

140 Ibid., 112.

${ }^{141}$ Waqar Zaidi, "Liberal Internationalist Approaches to Science and Technology in Interwar Britain and the United States," in Internationalism Reconfigured: Transnational Ideas and Movements Between the War, ed. Daniel Laqua (London: I.B. Taurus, 2011), 38. 
Covenant noted a need for "advanced nations" to administer the territories of "peoples not yet able to stand by themselves under the strenuous conditions of the modern world" and thus, according to the League, "the well-being and development of such people form[ed] a sacred trust of civilization." ${ }^{" 142}$ During the interwar years, imperialism continued to be justified under the banner of "development." Even as conventions were passed by the League to end coercive labor practices, forced labor continued on development projects, such as roads and private plantations. ${ }^{143}$ Despite the rhetoric of improved living standards which surrounded discussions about development, maintaining control of raw materials and markets served as a major motivator for European powers' control of colonial territories. ${ }^{144}$ The pretense of internationalism was often markedly different from the actual state of affairs in many imperial domains.

After WWI, the amount of funding that went to empire development increased. It was assumed that improving the cultivation of resources in the Empire would ultimately help Britain's post-war recovery. The rise in consumer demands for new products was also a principle concern. The push to develop the Empire connected to meeting demand for products that the public desired. Finding new sources of goods, and helping to ensure their transfer globally, was a central part of the creation of a new imperial system. In order to facilitate their acquisition, scientific authorities were needed, and the EMB helped to mobilize a vast array of expertise to help develop its imperial resources.

${ }^{142}$ League of Nations. The Covenant of the League of Nations, Including Amendments Adopted to December, 1924. https://avalon.law.yale.edu/20th century/leagcov.asp

${ }^{143}$ Pedersen, The Guardians, 237.

${ }^{144}$ Ibid., 298. 


\section{$\underline{\text { Scientific Funding and the EMB }}$}

Leo Amery and his Under-Secretary, William Ormsby-Gore, used their central position at the Colonial Office to push for increased funding for development. With opposition to tariff reform a continual obstacle, Amery increasingly looked to scientific research as a central component of his campaign for preference, much like his Conservative predecessor Joseph Chamberlain. If Empire products were to be sold, resources would need to be levied. The Board was aware early on that it did little good to market products that it would not be able to generate. ${ }^{145}$ Empire development was a way of encouraging Empire trade without relying on legislation. As Michael Worboys has noted, "Research and technical services were a form of government assistance that did not compromise the principles laisser-faire... It was cheap and could always be portrayed as progressive and a sound long-term investment." 146 The Board's focus on science and development was effectively a way in through the back door, it allowed for the pursuit of new markets and the improvement of the domestic economy, without having to raise the controversial issue of tariffs.

The EMB aimed to show how science could play a crucial role in fostering a more prosperous future. Tallents and other liberal technocrats were aware of the Empire's dwindling power, but also believed that the economic, technical, and scientific cooperation of a new age was just beginning. ${ }^{147}$ Advancing the Empire's economic potential also meant fostering scientific research. Tallents remarked that England was

\footnotetext{
145 The Empire Marketing Board: A Years Progress (June 1927), 6. TNA CO 323/982/3

${ }^{146}$ Michael Worboys, 'British Colonial Science Policy, 1918-1939," in Les Sciences Coloniales: Figures et Institutions, ed. Patrick Petitjean (Paris: Orstom, 1996), 100.

147 Anthony, Public Relations, 29.
} 
"accustomed to think in terms of politics and industry" but "very rarely looks at the world through biological eyes." ${ }^{\text {148 }}$ The aims of the $20^{\text {th }}$ century version of Empire development was a brand of empire-building that stressed the human component of research. It aimed at being an "instrument of profound importance to the health and happiness of remote millions of people," reflecting tones of international benevolence and care. ${ }^{149}$ Development was also linked to the issue of unemployment. With the loss of markets, one of the principle issues identified after the War, it was assumed that further developing the Empire would aid domestic unemployment by improving the market for British goods, thus improving trade and industry. ${ }^{150}$ Scientific development was considered a means of alleviating international and domestic troubles though innovation and cooperation.

The EMB viewed their aims in a broad context, which would incorporate and reinforce the entirety of the supply chain. As one of its early reports would note, marketing was "not merely an affair of the newspaper, the hoarding, and the platform," rather, "it stretches back through retail shops and merchant houses, through cold stores and the holds of steamers to the distant harbours and railways and packing sheds and the yet more distant farms." ${ }^{151}$ Though concerned with marketing products, the cultivation of commodities was conceived of as just as valuable. As the Board would affirm: "The

\footnotetext{
148 Tallents, The Projection of England, 216.

149 Joseph M. Hodge, "Science, Development and Empire: The Colonial Advisory Council on Agriculture and Animal Health, 1929-43," Journal of Imperial and Commonwealth History 30, no. 1 (2002): 3.

${ }^{150}$ Hodge, Triumph of the Expert, 144.

151 The Empire Marketing Board: A Year's Progress (June 1927), 6. TNA CO 323/982/3
} 
scientist at his laboratory table serves its central purpose no less than does the salesman at his shop counter." 152 The EMB was aware of the need to incorporate scientific funding into their mandate, as it was centrally connected to the goal of marketing empire products.

While originally viewing the division of EMB funds as 65 percent to publicity, 15 percent to research, and 20 percent to marketing, Amery and the Board fully realized the importance of its research goals and concluded that 65 percent of its budget should instead go to research, 15 percent to publicity, and marketing remained at 20 percent. ${ }^{153}$ Though often envisioned by the public as primarily a publicity venture, Amery would recall that "a very large part of our work in the promotion of research contributed directly to the development of the colonial Empire." ${ }^{154}$ Much of the behind-the-scenes work of the Board in actuality involved funding research efforts at home and abroad. Colonies were historically expected to be self- sustaining, as not to burden the British taxpayer, however, the work of the EMB also represented the "first approach to a policy of centrally guided economic development." ${ }^{155}$ The EMB, thus, served as one of the first vehicles for directing public funds to development projects, a practice that would be augmented in the following decades.

${ }_{152}^{152}$ Empire Marketing Board. May 1929 to May 1930 (London: HMSO, 1930), 7.

${ }^{153}$ Amery, My Political Life II, 348.

${ }^{154}$ Ibid., 348-349.

${ }^{155}$ More formal attempts were embodied by the Colonial Development Fund, created in 1929 , a measure passed that gave a further $£ 1$ million per year for colonial development. Overseas Development Institute, Colonial Development: A Factual Survey of the Origins and History of British Aid to Developing Countries (London: Overseas Development Institute, 1964), 6; 11. 
Though the EMB did not produce research itself, it did extend funds in the forms of grants to research efforts at home and throughout the Empire. Between 1926 and 1932, the EMB would allocate $£ 1.65$ million, or approximately $£ 236,000$ per year, to scientific funding. ${ }^{156}$ Between 1926 and 1933, the EMB aided 138 research projects and 66 were completed before its demise. ${ }^{157}$ The allotment of grants was coordinated by the Research Grants Committee, who received grant proposals from various research efforts and provided recommendations for their approval. Grant funding tended to focus on issues connected to food and agriculture. Despite the growing industrial capacity in countries such as Canada and Australia, agricultural research provided the bulk of the EMB's awards. Research on the storage and transfer of foodstuffs, horticulture, pest management, and animal health - were all efforts that would help to improve the growth and, eventually, the sale of primary products.

However, the funds allotted by the Board was somewhat minimal compared to comparable U.S. institutions that had begun to mobilize in earnest. The U.S. Department of Agriculture had begun to spend $£ 2$ million annually on primary industry research, and the Carnegie Institute was utilizing an endowment of $£ 4$ million for primary and secondary research. ${ }^{158}$ Additionally, by 1931 the Rockefeller Foundation was committing $£ 3.8$ million annually to international research - including grants in the fields of the

${ }^{156}$ Helen Tilley, Africa as a Living Laboratory: Empire, Development, and the Problem of Scientific Knowledge (Chicago: University of Chicago, 2011), 95.

${ }^{157}$ P.J. Atkins "Food and the Empire Marketing Board in Britain, 1926-1933." Paper presented at the 8th Symposium of the International Commission into European Food History, Prague, Czech Republic (September 30 - October 5, 2003), 2.

158 "Science and the Nation," The Daily Examiner, August 18, 1927, 4. 
natural sciences, medicine, and public health. ${ }^{159}$ With Britain spending considerably less than what the U.S. had begun to on research, the Times warned that "Money devoted to research is not a luxury; it is not merely a sound investment; it is rather a condition of survival, without which the Empire cannot hope to keep abreast of its competitors in the economic field." ${ }^{160}$ Science and economic success came to be associated in ever more important ways. The push for scientific funding continued to be justified as a vital component of economic relief for the British Empire

The Research Grants Committee made a point to require certain criteria for grants and it utilized multiple resources to help decide on a given proposal's approval. ${ }^{161}$ Based on their guidelines, successful applications should "aim at improving the quality, increasing the quantity, or eliminating wastage in the production and marketing, of Empire commodities. ${ }^{162}$ They were also required to have wider appeal to more than one Empire country, meet scientific merit as well as more a general assurance of "economic usefulness," the cooperation with other Empire countries and sharing of results should be secured, and - when possible - grants should be matched by private contributions. ${ }^{163}$ Upon receiving proposals the Committee circulated copies to scientific agencies or

${ }^{159}$ Tilley, Africa as a Living Laboratory, 95. 160 "Empire Research," The Times, Nov 23, 1926, 9.

${ }^{161}$ Member of the Research Grants Committee included, at the outset, figures such as Major Walter Elliott, Conservative MP and Parliamentary Under Secretary for Health for Scotland, Colonial Under-Secretary William Orbsby-Gore, Parliamentary Secretary to the Ministry of Agriculture and Fisheries - Lord Charles Bathurst, and several civil servants that had experience with food and government, including Australian representative Frank Lidgett McDougall and economist and nutrition expert E.M.H. Lloyd.

${ }^{162}$ An Analysis of the Research Grants Policy of the Empire Marketing Board," report presented to the Imperial Conference Inter-Departmental Committee on Economic Questions (September 8, 1930), 2. BL IOR/L/E/7/1535 ${ }^{163}$ Ibid. 
Dominion governments that advised on their merits and prevented the duplication of work $^{164}$ The EMB's utilized a network of scientists and scientific institutions that were able to advise on the merits of research studies. It was this network that helped to further the EMB's ultimate goal of restructuring trade, as one poster illustrated, to "make the Empire share larger," increasing the production of goods from the Empire. (Fig. 6).

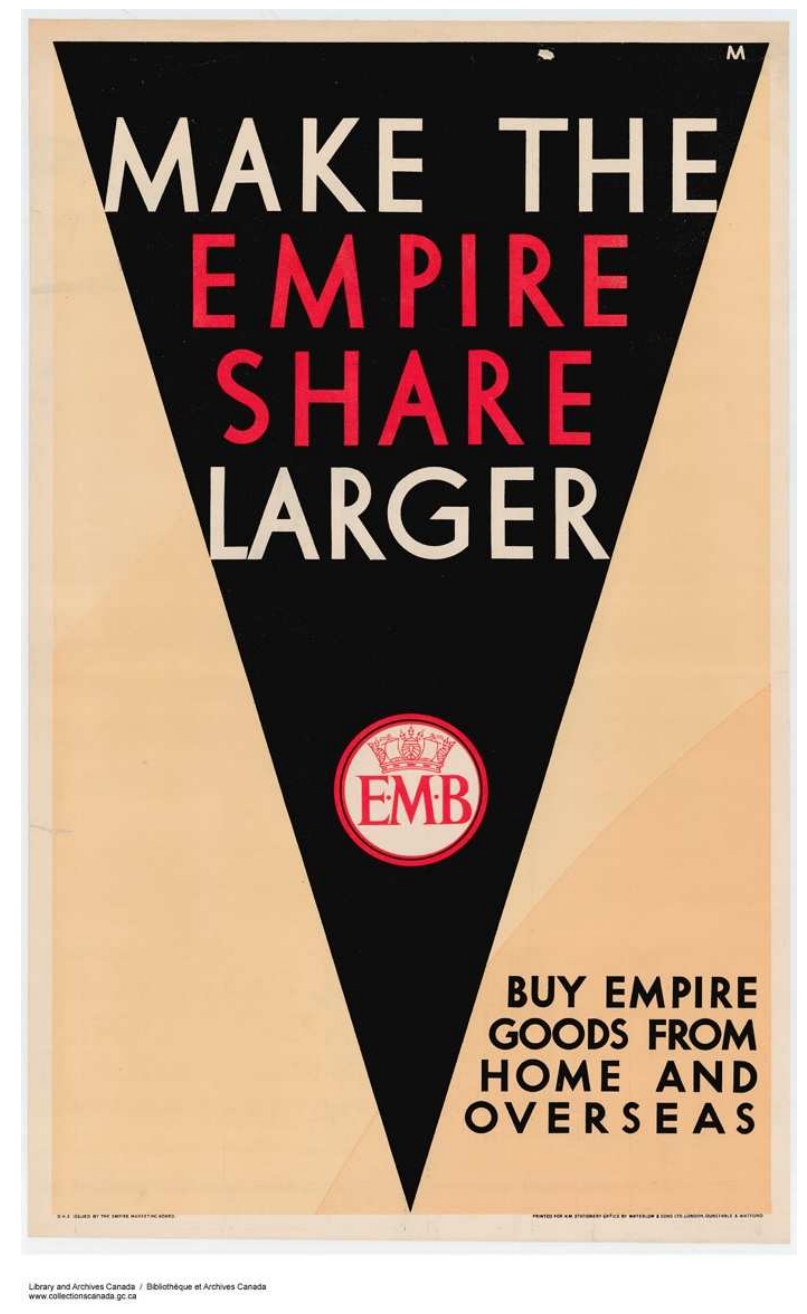

${ }^{164}$ Departments often turned to for council included the Agricultural Departments, The Colonial Advisory Council on Agriculture and Animal Health (CAC), the Agricultural Research Council, the Department of Scientific and Industrial Research, the Development Commission, the Medical Research Council and the Imperial Institute. The Empire Marketing Board Report Presented to the Imperial Economic Conference. Part II. Grants for Scientific Research and Other Schemes (1933), 8. BL IEC/Q/18/2 
Figure 6. Make the Empire Share Larger. Lithograph. 62 x $100.3 \mathrm{~cm}$. Library and Archives Canada. Ottawa, Ontario. MIKAN 2844857. http://www.bac-

lac.gc.ca/eng/CollectionSearch/Pages/record.aspx?app=fonandcol\&IdNumber=2844857\&new=$\underline{8586297445919455532}$

\section{Cold Food Storage}

The EMB's research funds were directed to many different aims but a primary concern, and one to which considerable funds were directed, was the study of cold food storage. The ability to ship food over long distances had been enhanced by new technologies in refrigeration. As the British Food Journal reflected, "When men still alive to-day were young, not a single cargo of chilled or frozen meat, of fruit or of dairy produce from the Southern Hemisphere, had been landed in this country. We have, that is, lived in the last generation through a dietetic revolution." ${ }^{165}$ Despite this food revolution, however, problems still arose in perfecting the technologies that moved goods from the furthest reaches of the Empire. As the article illustrated, "Living matter does not suffer coercion gladly or passively." ${ }^{166}$ While progress had been made, problems still persisted in cooling and shipping technologies. Empire goods still faced competition from less-distant producers, which were often preferred by consumers over the "harsher product," that had to travel further distances. ${ }^{167}$

One example of this concern was the growth of the meat industries of New Zealand and Australia. The growth of both industries originated with the refrigeration technologies of the later $19^{\text {th }}$ century. Shipping perishable meat the 13,000 miles between

\footnotetext{
165 "British Food Journal Volume 29 Issue 9 1927," British Food Journal 29, no. 9 (1927): 81-90.

${ }^{166}$ Ibid.

167 "Dominion Food Products," The Times, August 11, 1925, 7.
} 
New Zealand and Britain seemed, at the time, a daunting task. ${ }^{168}$ The transition from sail to steam and the development of cold storage facilities at docks and on ships helped to facilitate the shift. The first meat shipments from Australasia were sent 1879, but they were initially the victim of consumer prejudice. ${ }^{169}$ However, the resistance shifted as wider and faster distribution of meat lowered its cost, allowing it to be enjoyed even by working class consumers. WWI, which required that most people eat some form of imported meat - and finding that it was not so bad - improved imported meat's reputation. $^{170}$

Beef that was shipped from Australia or New Zealand, however, could only be sent frozen, as it deteriorated too quickly to be shipped chilled. But beef that required less travel time, such as that of Argentina or Denmark, could be shipped chilled. Consumers often preferred it over frozen, and frozen meat increasingly went mainly to the Army and other public institutions. ${ }^{171}$ Advertising for the EMB utilized technological innovation as a marketing tactic, illustrating the shift in trade between the $19^{\text {th }}$ century and the present (Fig. 7) However, the poster also obscured the foreign competition that had resulted from of such technologies. Thus, the interest in research on cold storage was also aimed at finding ways to improve technologies to improve Empire products to keep pace with foreign competition.

\footnotetext{
${ }^{168}$ Rebecca H.J Woods, "Breed, Culture and Economy: The New Zealand Frozen Meat Trade, 1880-1914," Agricultural History Review 60, no. 2 (2012): 290.

${ }^{169}$ R. Duncan, "The Demand for Frozen Beef in the United Kingdom, 1880-1940," Journal of Agricultural Economics 12, no. 1 (June 1954): 83.

${ }^{170}$ Ibid., 83-84.

${ }^{171}$ Ibid., 87-88.
} 


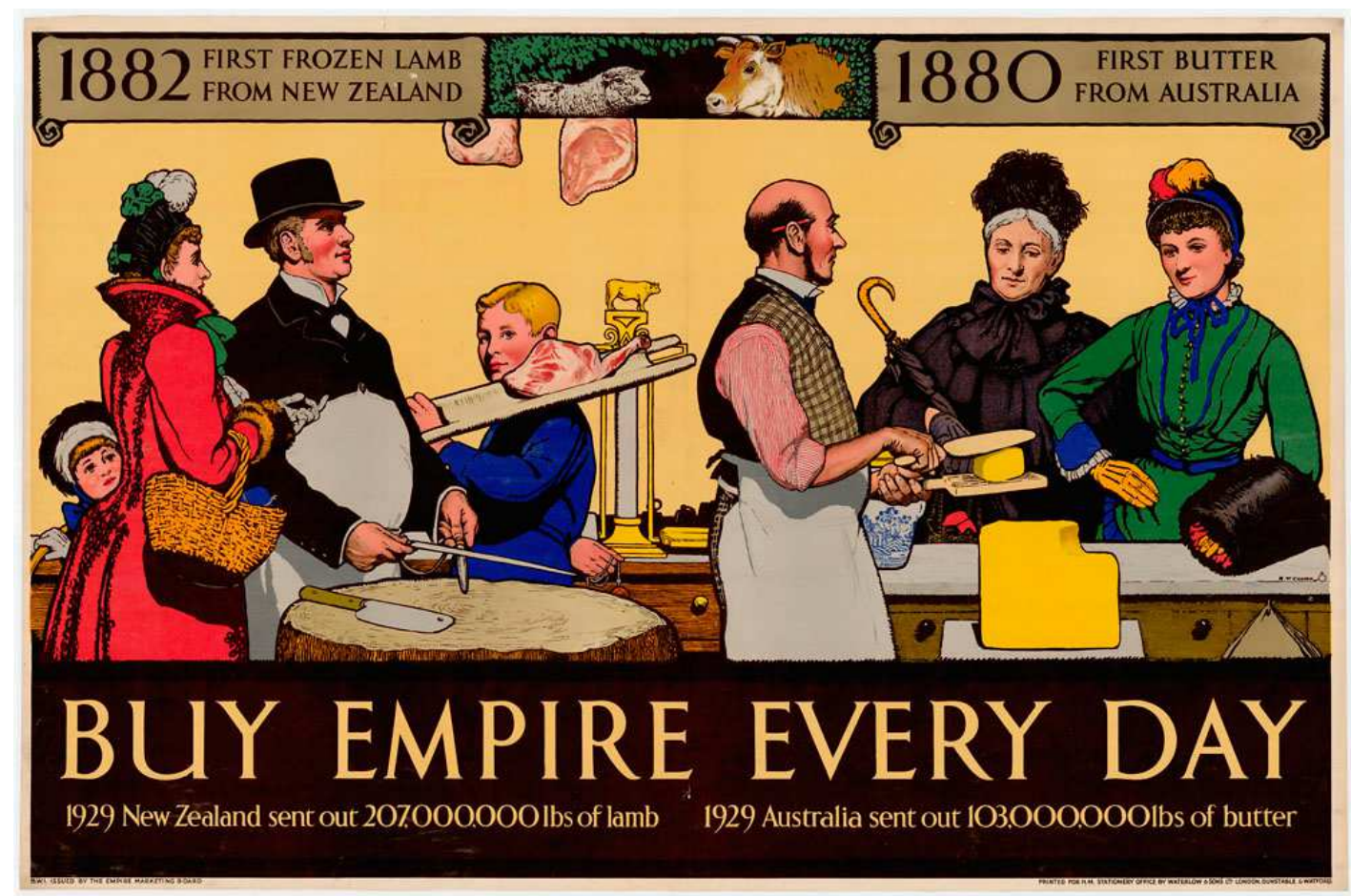

Library and Archives Canada / Bibliothéque et Archives Canada
www. collectionscanada.gc.ca

Figure 7. R.T. Cooper. 1907 First Oranges from South Africa, 1903 First Sultanas and Currents from Australia: Buy Empire Every Day. Lithograph. 151.8 X $101.1 \mathrm{~cm}$. Library and Archive Canada. Ottawa, Ontario. MIKAN 2845186. http://www.bac-

lac.gc.ca/eng/CollectionSearch/Pages/record.aspx?app=fonandcol\&IdNumber=2845186\&new=$\underline{8586297458635655572}$

The chief recipient of funds for cold storage research was the Low Temperature

Research Station at Cambridge. There, the grant went to investigating cold storage

problems associated with fruit, meat and dairy products. ${ }^{172}$ The issue of storage was a

significant as meat and produce from the Dominions and colonies were highly susceptible to damage before they made it to their destination, and it was especially vital given the foreign competition. The Low Temperature Research Station's cold storage lab was equipped with facilities to investigate the temperature requirement for shipment over long

${ }^{172}$ Empire Marketing Board, Note on the Work and Finance of the Board, 7. 
distances. ${ }^{173}$ Researchers also conducted experiments onboard ships themselves, in conjunction with the New Zealand Department of Scientific and Industrial Research, both on ships traveling to and returning from New Zealand. ${ }^{174}$ It was often difficult to study precisely the factors that affected the transfer from the site of production to its destination because where products sat in the ship could affect temperature and ventilation, and therefore its freshness. ${ }^{175}$ In recreating shipping conditions it was hoped that Empire food shipment to Britain could be better preserved.

Similar experiments on cold storage were established at the East Malling Research Station in Kent. Both grants, those of Cambridge and East Malling, were administered by the Department of Scientific and Industrial Research in the U.K. and worked in consultation with the other. The funds went to the construction of research laboratories which made East Malling the largest cold storage facility in the world, able to hold 120 tons of fruit under controlled conditions. ${ }^{176}$ Prolonging the storage of goods through experiments with preservative gases, which would allow producers to store their goods year-round, was another area of study. ${ }^{177}$ If the Empire was to develop and improve the quality of meat from New Zealand or oranges in South Africa further research would be necessary.

173 Empire Marketing Board, May 1931 - May 1932, 17.

${ }^{174}$ Empire Marketing Board, May 1929 - May 1930, 23.

${ }^{175}$ Murton, "John Bull and Sons," 238.

176 The Empire Marketing Board Report Presented to the Imperial Economic Conference, Committee on the Economic Consultation and Cooperation (1933), 2. BL IEC/Q/18/2

${ }^{177}$ Empire Marketing Board, May 1931- May 1932, 18. 
The Board was also aware that it needed to publicize its scientific undertakings, to make the public aware of what it was trying to accomplish. In one of the advertisements taken out by the EMB in the Times, the Board noted that detailed investigations had been undertaken on food research. They were quick to emphasize that scientific research meant efficiency. The advertisement affirms that research on cold food storage meant “cheaper, more plentiful, more varied," goods (Fig. 8). The use of science thus helped to ensure that quality goods would make it to consumer's tables. The loss of food products meant increased costs for consumers, so the EMB sought to justify its undertakings by illustrating that utilizing funds for scientific research ultimately helped buyers in the long run by making their food more cost-effective. 


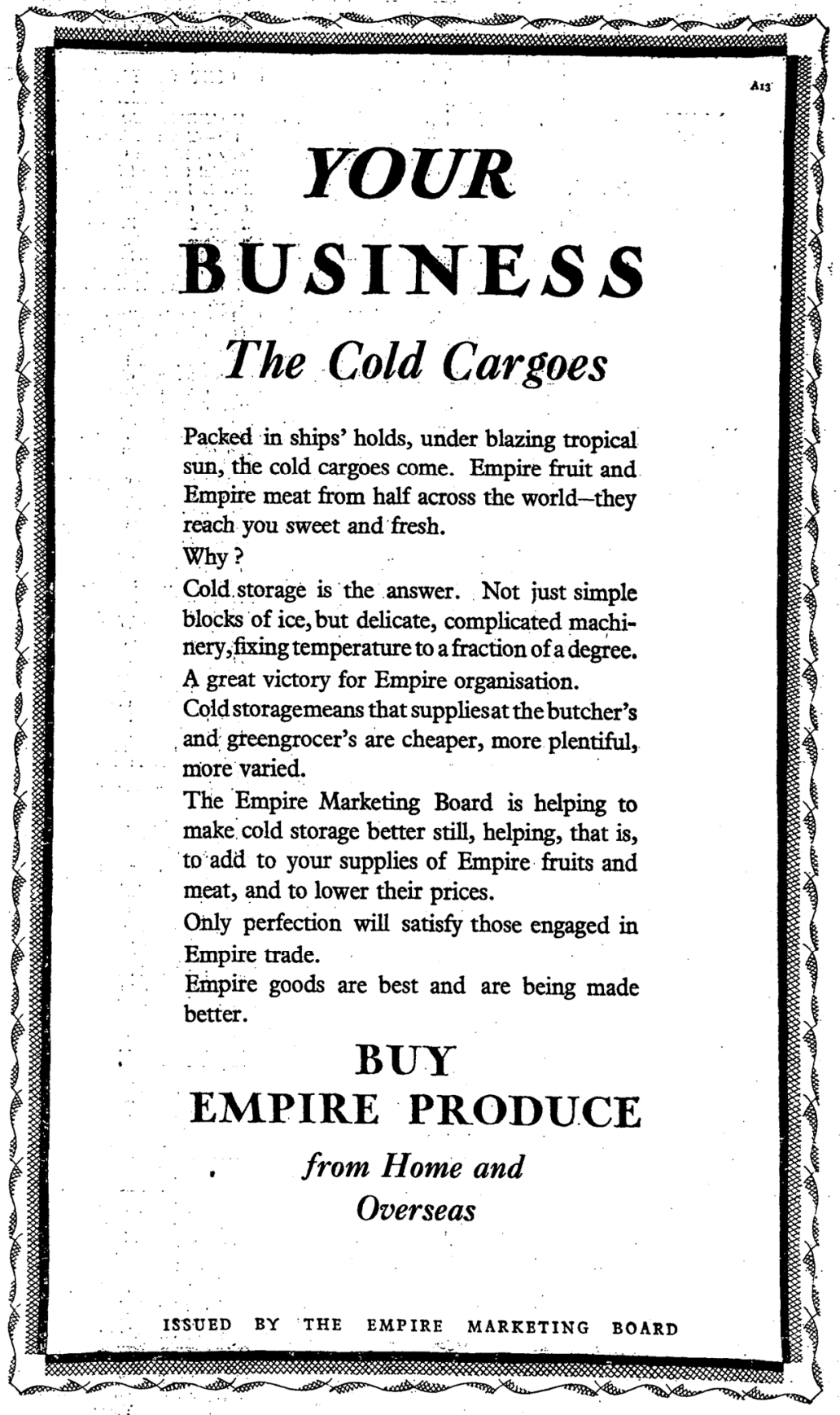

Figure 8. "Empire Produce." The Times, July 8, 1927, 8.

\section{$\underline{\text { Pest Control }}$}

Another central concern for the EMB was the issue of pests and the damage they caused to crops. It was estimated that approximately 10 percent of the world's crops were 
destroyed every year by insects. ${ }^{178}$ Additionally, pests damaged 20 percent of crops grown in tropical regions, which made it a central concern for scientific expenditure. ${ }^{179}$ They were also especially detrimental because some types could kill livestock, another valuable Empire commodity. Studies on animal immunity were funded at the Liverpool School of Tropical Medicine's research facilities in Sierra Leone, to investigate the building up of immunity to pests such as the warble fly. ${ }^{180}$ The Natural History Museum's Department of Entomology also received considerable funds for their collections and library. It was expected that funds would help to identify the insects that continued to prove most harmful to humans, animals and agricultural products ${ }^{181}$ The Imperial Institute of Entomology established a "parasite zoo" for the breeding and dispersing beneficial parasites, with 200 consignments being sent to the Empire including to Canada, Australia, New Zealand, South Africa, India and the colonies. ${ }^{182}$

Funding resources were also granted to the Imperial College of Science and Technology, for new research facilities at the Biological Field Station in Slough. The work was focused on the study of insect and fungi infestations on stored foods. J.W. Munro and W.S. Munson found that there was a lack of research on stored products, noting that London warehouses were often subject to infestation, leading to further loss

\footnotetext{
${ }^{178}$ Imperial Conference, 1926: General Economic Sub-Committee, 47. TNA CO 323/965/18

${ }^{179}$ Empire Marketing Board: A Year's Progress, (June 1927), 10. TNA CO 323/982/3

${ }^{180}$ Empire Marketing Board, May 1927-May 1928, 16.

181 "Empire Marketing Board." The Times, July 18, 1928, 9.

182 "The Empire Marketing Board Report Presented to the Imperial Economic Conference" (1933). BL IEC/Q/18/2
} 
for producers. ${ }^{183}$ This was also especially dangerous, as it could damage their reputation if they were found to have infested goods. ${ }^{184}$ In addition to lab studies, docks and warehouses were investigated to show how producers, manufacturers, dockworkers and retailers could cooperate to prevent such storage problems. ${ }^{185}$ Australian dried fruits, dairy produce in New Zealand, tobacco from Rhodesia and Nyasaland, West African cocoa, and Malayan copra were among the commodities that were studied. ${ }^{186}$ The experiments included many further efforts centered on investigations into preventing the loss of crops and animals.

In another of the Board's Times advertisements, they illustrated more of their research aims, as a way of attempting to make more esoteric research understandable to readers and further validate their efforts (Fig. 9). The advertisement re-emphasized the importance of productivity. It affirmed that waste caused by pests "means higher prices, lower profits and less prosperity for everyone," signaling to readers the dangers of unproductive and unscientific agronomy. It further emphasized that the research supported by the Board was helping to increase efficiency. Most importantly, the research that was done by the EMB helped to keep costs down. By preventing the waste of valuable commodities and making sure that goods made it to their destination, the Board

${ }^{183}$ J.W. Munro and W.S. Thomson. Report on Insect Infestation of Stored Cacao (London: HMSO, 1929).

${ }^{184}$ J.W. Munro, "Infestation of Stored Products by Insects," Nature 82 (January 21, 1933): 82.

${ }^{185}$ Ibid., 83.

186 The Empire Marketing Board Report Presented to the Imperial Economic Conference. Part II. - Grants for Scientific Research and Other Schemes (1933), 5. BL IEC/Q/18/2 
emphasized their important role in the process of streamlining the transfer of products. In turn, they encouraged consumers to do their part by buying Empire goods.

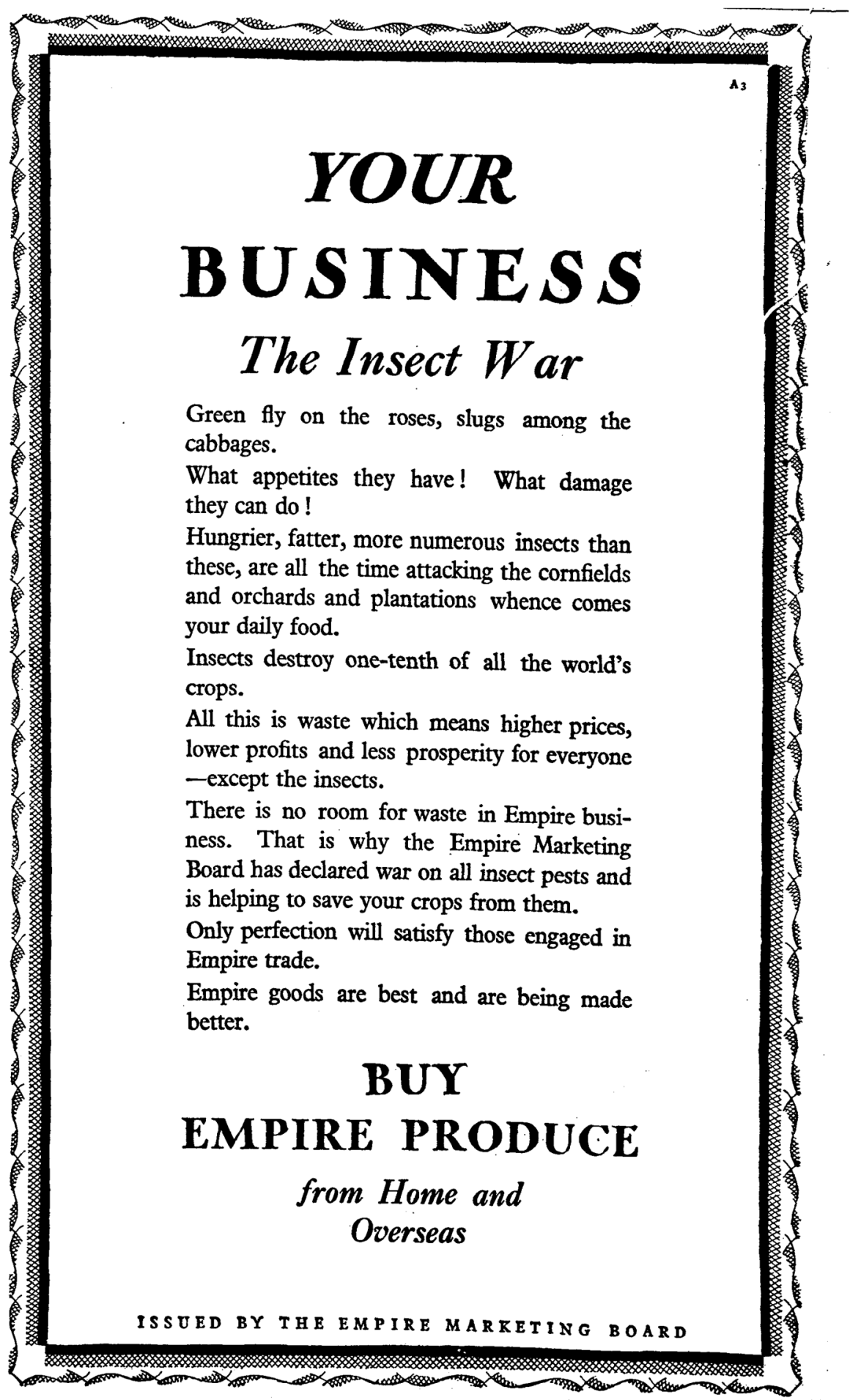

Figure 9. "The Empire Marketing Board.” The Times, July 1, 1927. 


\section{Nutrition Research}

Research efforts also were furthered to help revitalize domestic agriculture.

Walter Eliot, one of the Research Committee members, made funds available for his former colleague, Dr. John Boyd Orr, the Director of the Rowett Research Institute in Scotland to carry out surveys on nutrition. ${ }^{187}$ The studies were linked to the dual problems of malnutrition and the decline of British agriculture. The Military Service Acts, which mandated conscription into the armed forces during the WWI, had helped to illustrate deficiencies in diet among the British population. ${ }^{188}$ By 1924 , the Medical Research Council had published studies illustrating the importance of vitamins in the maintenance of a healthy diet. The perception was that malnutrition was due to miseducation, and it increasingly became part of the state's mission to intervene on issues of public health. ${ }^{189}$ The other more pressing concern was the decline in British agriculture after the War, falling from 12.4 million acres of land in 1918 to 10 million by the next decade. ${ }^{190}$ Milk demand was sluggish and market conditions were inconsistent due to the varied quality of milk. ${ }^{191}$ Britain still consumed less milk per head than other countries

\footnotetext{
187 The studies argued for the correlation of milk and improved nutrition among Scottish schoolchildren. Over the course of seven months, Orr noted a 20 percent increase in height and weight of the children in the study. Further funded efforts the following year among 1157 children also showed similar increases J.B. Orr, "Milk Consumption and the Growth of School Children," The Lancet 211, no. 5448 (1928): 203; Gerald Leighton and Mabel L. Clark, "Milk Consumption and the Growth of School Children, Second Preliminary Report on Test to the Scottish Board of Health," British Medical Journal 1, no. 3548 (Jan. 5, 1929): 25.

${ }^{188}$ Derek J. Oddy, From Plain Fare to Fusion Food: British Diet from the 1890's to the 1990 's (Woodbridge, Boydell Press, 2003): 114.

189 Atkins, "School Milk in Britain," 399.

${ }^{190}$ Oddy, From Plain Fare to Fusion Food, 95.

${ }^{191}$ Peter Atkins, "School Milk in Britain, 1900-1934," Journal of Policy History 19, no.4 (2007): 399.
} 
(Figure 10). It was hoped that by promoting the healthy benefits of milk consumption, it would help to stimulate British agriculture and improve markets for dairy farmers.

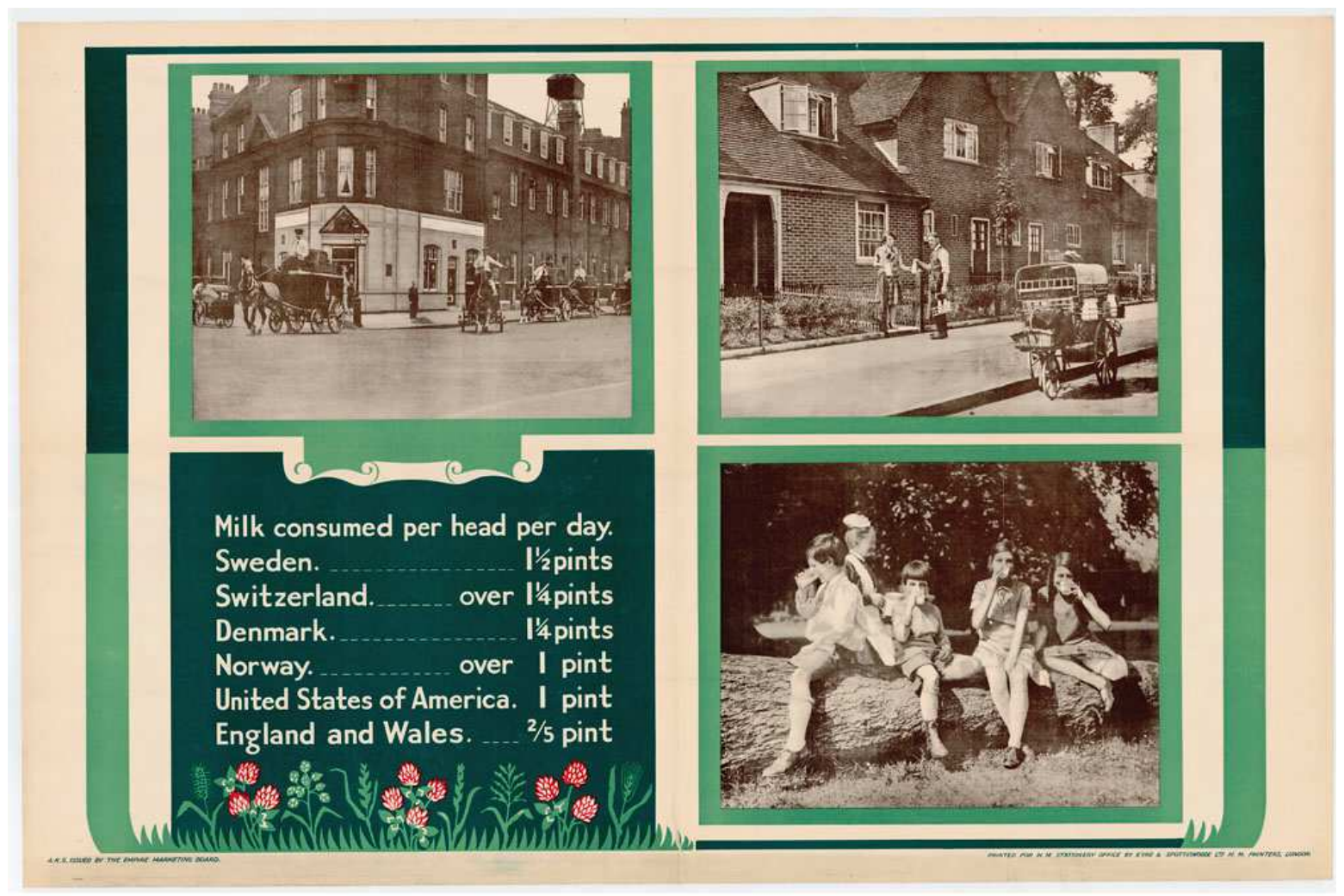

Library and Archives Canada / Bibliothèque et Archives Canada wwe collectionscanada.gc ca

Figure 10. Milk Consumed Per Head Per Day. Lithograph. 151.4 x $101.3 \mathrm{~cm}$. Library and Archives Canada, Ottawa, Ontario. MIKAN 2845152. http://www.bac-

lac.gc.ca/eng/collectionsearch/Pages/collectionsearch.aspx?DataSource=Images \&q=empire + marketing + bo ard\&start $=250 \&$ num $=50 \# 1-7$

The issue of quality among dairy producers was also a concern. Reports noted that Empire butter and cheese sometimes arrived in a "faulty condition," causing not only 
financial loss but "damage the reputation of the country of origin," as well. ${ }^{192}$ The National Institute for Research in Dairying was founded in 1913 by Development Commissioners and the Ministry of Agriculture and Fisheries to study the national concerns of the dairy industry. The EMB also extended funds to the Institute for studies on other dairy-related concerns such as bovine tuberculosis and deficiencies in dairy supplies. ${ }^{193}$ The establishment of a dairy research journal by the Institute was also developed to further efforts to improve the quality of dairy products and facilitate cooperation in research ${ }^{194}$ The Board turned its resources to efforts that would aid struggling domestic industries, such as home farming, as well as improving the quality and consistency of Empire products.

It was also sometimes the case that private companies took advantage of the EMB's research to sell their own products. In one instance, chocolate manufacturer Cadbury's capitalized on the research of the EMB to sell its chocolate. The Board had issued a pamphlet, "What Milk Can Do," publicizing the findings of Orr's research study on milk. Cadbury's used the study as a marketing tactic, emphasizing the benefits of chocolate as a preventative against malnutrition. Cadbury's had marketing products like the Dairy Milk Bar and referred to its bars as "sunshine chocolate," due to its vitamin D content. ${ }^{195}$ Cadbury's used EMB-funded research to portray chocolate a healthy snack

${ }^{192}$ Research on Dairying Problems by the National Institute for Research in Dairying: Letter from Ministry of Agriculture and Fisheries Giving Observations on Scheme and Forwarding Application by the Institute for a Grant. TNA CO 323/962/7

${ }^{193}$ Empire Marketing Board, May 1929 - May 1930, 66-67; Empire Marketing Board, May 1931- May 1931, 34-35.

${ }^{194}$ Ibid.

${ }^{195}$ M. French, "Modernity in British Advertising: Selling Cocoa and Chocolate in the 1930's," Journal of Historical Research in Marketing 9, no. 4 (2017): 10. 
which could help stave off "milk starvation." (Fig. 11). Interestingly, it also emphasized the support provided to domestic agriculture through its purchase, a tactic that would also be utilized by the EMB themselves. The Board utilized advertising tactics, but, at times, through the blurring of the scientific and commercial spheres, the advertising world also utilized the EMB's research work to sell its own products. 


\section{WHAT MILK CAN DO}

"The Times" Leader of December 3Ist, 1928, commenting on a letter from the Chairman of the Research Grants Committee, Empire Marketing Board, says:-

"The majority of people, both young and old, are suffering from 'milk starvation,' a complaint which robs its victims of the bodily fitness they ought to enjoy and of the full powers of resistance to disease of which they are capable." ... "In its homeproduced dairy products, this country possesses the essential elements of strength and vigour. Money expended on these home-produced products is money invested in good health."

A delicious, convenient and concentrated form of milk is Cadbury's Milk Chocolate; $1 \frac{1}{2}$ glasses of fresh, full cream English milk being used in the manufacture of every $\frac{1}{2} \mathrm{lb}$. The chocolate retains all the cream, proteins, sugars, phosphates and calcium of the original milk as well as the important Vitamins A (anti-infective), B and D. Owing to the concentration of the milk, the chocolate possesses twice as much of the sunshine Vitamin $D$ as is found in fresh milk. The whole of the milk used in Cadbury's Milk Chocolate comes from the rich pastures of Shropshire and Gloucester, and every purchase of Cadbury's Milk Chocolate is a direct aid to British Agriculture.

\section{CADBURY'S MILK CHOCOLATE}

Obtainable in $\frac{1}{2}-l b$. Blocks, $1 /-; 6 d$. Packets and $2 d$. Bars

Figure 11. “The Times,” The Times, January 5, 1929. 


\section{Collaborative Research}

Research efforts funded by the Board also involved cooperative projects. Though the bulk of research funding went to institutions in the UK, attempts were made to extend funds to other parts of the Empire to encourage scientific collaboration among scholars and institutions. The Ministry of Agriculture was aware early-on of the need to bring scientific interests together in collaboration, noting that "Scientific workers in the same branch of science in all parts of the Empire should be encouraged to come into direct contact. The one with the other." ${ }^{196}$ Bureaucrats, technical experts, and academics from across the Empire influenced the development of scientific research. The research encouraged by the EMB help to illustrate the networks that were mobilized to further the Board's aims.

The Research Grants Committee formed extensive relations to parallel advisory councils that stressed the importance of research and the Empire's colonies. The Colonial Advisory Council on Agriculture and Animal Health (CAC) was founded in the hopes of overseeing a unified network of research stations throughout the Empire. The Council was made up of prominent members of the scientific community. ${ }^{197}$ The EMB agreed to

\footnotetext{
196 "Empire Marketing Board Research Committee: Memorandum Prepared by the Ministry of Agriculture and Fisheries on an Imperial Chain of Research Stations" (January 12, 1926), 3-5. TNA CO 323/962/1

${ }^{197}$ Member in included member of the scientific elite, including individuals such as Sir E. John Russell, the Director of Rothamsted Research Institute; T.B. Wood, Professor and Chair of the School of Agriculture at Cambridge; John Boyd Orr, Director of the Rowett Research Institute, Aberdeen; Sir William Furse, Director of the Imperial Institute; Dr. Arthur W. Hill, Curator of the Royal Botanical Gardens, Kew; Dr. W. Homer Andrews, Director of the Veterinary Laboratory at the Ministry of Agriculture and Fisheries; and Dr. Guy A. K. Marshall, Director of the Imperial Bureau of Entomology; See Hodge, "Science, Development and Empire," 9; 23.
} 
fund $£ 22,000$ toward the project, with the rest of the funding to be paid from a central fund. ${ }^{198}$ The first links were envisaged between tropical and subtropical research institution in in Trinidad, Tanganyika, and Australia. ${ }^{199}$ The focus was aimed at longterm commodity research that could not be conducted by local agricultural efforts alone.

The coordination of such as scheme relied on funding from colonial governments. While African dependencies were in favor of such a scheme, other governments such as Ceylon, the Federated Malay States, and West Indian officials were more critical, preferring not to contribute to the new scheme along with other research commitments, or, in the case of Malaya, to fund research efforts in poorer colonies of which it may see little benefit. ${ }^{200}$ Some researchers were skeptical of greater central oversight, preferring to work within more localized networks. For these reasons a central research schema never emerged, and the CAC remained only an advisory body. These all illustrate the complications between colonial administration and British government officials about how science in the Empire would be conducted. Tensions were exemplified by ongoing conflict between those that desired a more "centralized" approach to scientific research and those that saw the importance of local specificity. ${ }^{201}$ Collaborative research aims were in some instances less successful than others.

\footnotetext{
198 Hodge, "Science, Development and Empire," 5.

${ }^{199}$ Empire Marketing Board. Note on the Work and Finance of the Board and Statement of Research and Other Grants Approved by the Secretary of State for Dominion Affairs from July, 1926, to March, 31 st., 1928 (London: HMSO, 1928), 6.

${ }^{200}$ Hodge, "Science, Development, and Empire," 5-6.

201 Tilley, Africa as a Living Laboratory, 130.
} 
However, international cooperation among scientists continued to be seen an important part of the EMB's goals. Collaborative research efforts were funded in recognition that solving one scientific problem often required international cooperation. One effort aimed at study on the mineral content of pastures combined work in Scotland, Australia, New Zealand, and Southern Rhodesia. Grasses were a major concern because many of the Empire's vital commodities, -- meat dairy, wool, and hides - together valued at $£ 426$ million yearly, depended on it ${ }^{202}$ However, one of the largest hinderances to herd and flock maintenance was the lack of soil minerals, which could cause malnutrition or death in animals. The Rowett Research Institute in Scotland had been studying fertilizers, grasses used for hay, and how the nutritional content of feed for cattle changed under certain conditions. ${ }^{203}$ Funding was extended to the workers in Southern Rhodesia to train in Scotland and returned to Africa and established similar experimental stations to study soil conditions and fertilizers. ${ }^{204}$ In Australia, the Waite Agricultural Research Institute of Adelaide University had received funds to study soil fertilizers and nutritional deficiencies in grasses and its effects on animals. ${ }^{205}$ Similar studies on nutrition and soil deficiencies were conducted at the Cawthron Institute in New Zealand to further investigate the optimal nutrient content for pastures and livestock. It was assumed that

202 "The Value to Australia of the Work of the Empire Marketing Board and the Importance of Imperial Co-operation in Research," (1933), 2. BL IEC/Q/18/3.

203 "An Analysis of The Research Grants Policy of the Empire Marketing Board," 22-23. $\mathrm{BL} \mathrm{IOR} / \mathrm{L} / \mathrm{E} / 7 / 1535$.

${ }^{204}$ Empire Marketing Board, May 1931- May 1932, 29.

205 "The Value to Australia of the Work of the Empire Marketing Board and the Importance of Imperial Co-operation in Research," (1933), 2-3. BL IEC/Q/18/3. 
collaboration among Empire institutes could help to more fully elucidate research problems through the sharing of research and resources.

To publicize such research work, the EMB also proposed the commissioning of scientific films that would also illustrate to the public the nature of the work that they were funding. As will be show further in in chapter four, films played a crucial role in exhibiting the EMB's message to consumers. Films that focused more specifically on scientific topics were suggested to illustrate its research work. One proposed film, Grasslands of the Empire, was proposed as an educational resource to illustrate the collaborative research that had been conducted on pastures that mineral deficiencies and illustrate to consumers how it affected various commodities of the Empire. Illustrating research through film was expected to "prove of real instructional benefit to agriculturalists and in addition be of considerable interest to more general audiences." 206 Orr, through his connections to Walter Elliot, a member of the Film Committee as well as the Research Committee, was consulted for the creation of the film. Though the film was never produced, Orr did work on other nutrition films with his former EMB colleagues in the 1930's. In the film's screenplay, it asserted that "as a result of the scientific approach to the problem millions of rich acres will be added to the Empire's grasslands. Animals will be healthier... Prices will be better. The problem of mineral deficiencies is an Empire-side problem and it is being handled on an Empire wide scale."207 The work

\footnotetext{
${ }^{206}$ Film Committee. Minutes of the Ninth Meeting Held in the Board's Conference Room on Tuesday, $23^{\text {rd }}$ July, 1929 TNA CO 760/37

${ }^{207}$ Empire Marketing Board. Film Committee. Pasture Research Film. October 24, 1929. TNA CO 760/37
} 
further shows that the key aspect of the EMB's research aim's was in trying to reach the public and instruct consumers about its work and its message.

\section{Colonial Research Stations and Networks of Science}

The EMB's interest in colonial research was centered around the tropical and subtropical regions where food and raw materials were in increasing demand. In his surveys conducted for the EMB, C.A. Barber noted that demand for tropical commodities had unleashed a whole series of new difficulties: the compromising of plant quality for larger quantities, systems of monoculture, and the gradual erosion of virgin and fertile soil being some of the concerns associated with modern cultivation. ${ }^{208}$ "In a sense, science is responsible for these altered conditions, he noted, "and it is natural to look to it for the appropriate counter measures and remedies for the evils that it has created." ${ }^{209}$ Therefore, the training of experts who could address modern scientific problems became central to tropical agricultural research efforts. Barber pointed to the wide range of expertise that was required for Empire development:

The services of the following are liable to be called in: for the soil, the chemist, physicist, and biochemist: for its treatment, the agriculturist, horticulturist, engineer and economist: for the plant, the systematist, physiologist, morphologist, and plant breeder; and for its ailment the entomologist and mycologist. Besides these, and especially in tropical conditions, we need the constant services of the meteorologist and the forester and, as regards labour, the ethnologist, linguist, and the medical man. ${ }^{210}$

\footnotetext{
${ }^{208}$ C.A. Barber, Tropical Agricultural Research in the Empire: With Special Reference to Cacao, Sugar Cane, Cotton and Palms (London: HMSO, 1927), 18-19.

${ }^{209}$ Ibid., 19.

${ }^{210}$ Ibid.
} 
In order to solve the issues presented by large-scale crop cultivation, a vast array of expertise was needed to mold and remake the natural environment for imperial purposes.

Tropical research institutes that were given grants by the EMB including the Imperial College of Tropical Agriculture in Trinidad (Fig. 12). The ICTA served as a research station and a center for postgraduate training. The research facilities and laboratories of the Imperial College were aimed at teaching future planters and officers about agricultural sciences, as there was a lack of trained officers in the West Indies. ${ }^{211} \mathrm{It}$ was also hoped that training more personnel in the new field of plant pathology would help to gain a more substantial understanding of virus diseases, especially in the tropics which affected some of the Empire's most valuable products. ${ }^{212}$ Scientific knowledge was also intertwined with commercial concerns. The ICTA had also received funding from commercial interests to further research on products like cotton. The Empire Cotton Growing Corporation had previously provided funds for post-graduate scholarships allowing students to spend a year at the facility and had also provided the ICTA with a cotton research station. ${ }^{213}$ The ICTA helps to illustrates the alliances that could be forged between scientific institutions, government and corporate entities. Funding was granted to such institutes in exchange for their commodity work and their assistance to the British cotton industry.

${ }^{211}$ H.C. Sampson, Report on the Development of Agriculture in British Honduras. London: HMSO, 1929), 8.

212 "An Analysis of The Research Grants Policy of the Empire Marketing Board," submitted to the Inter-departmental Committee on Economic Questions at the 1930 Imperial Conference, September 8, 1930, 18. BL IOR/L/E/7/1535.

213 "Imperial Conference: 1926 General Economic Sub-Committee Report, 315. TNA CO $323 / 965 / 18$ 


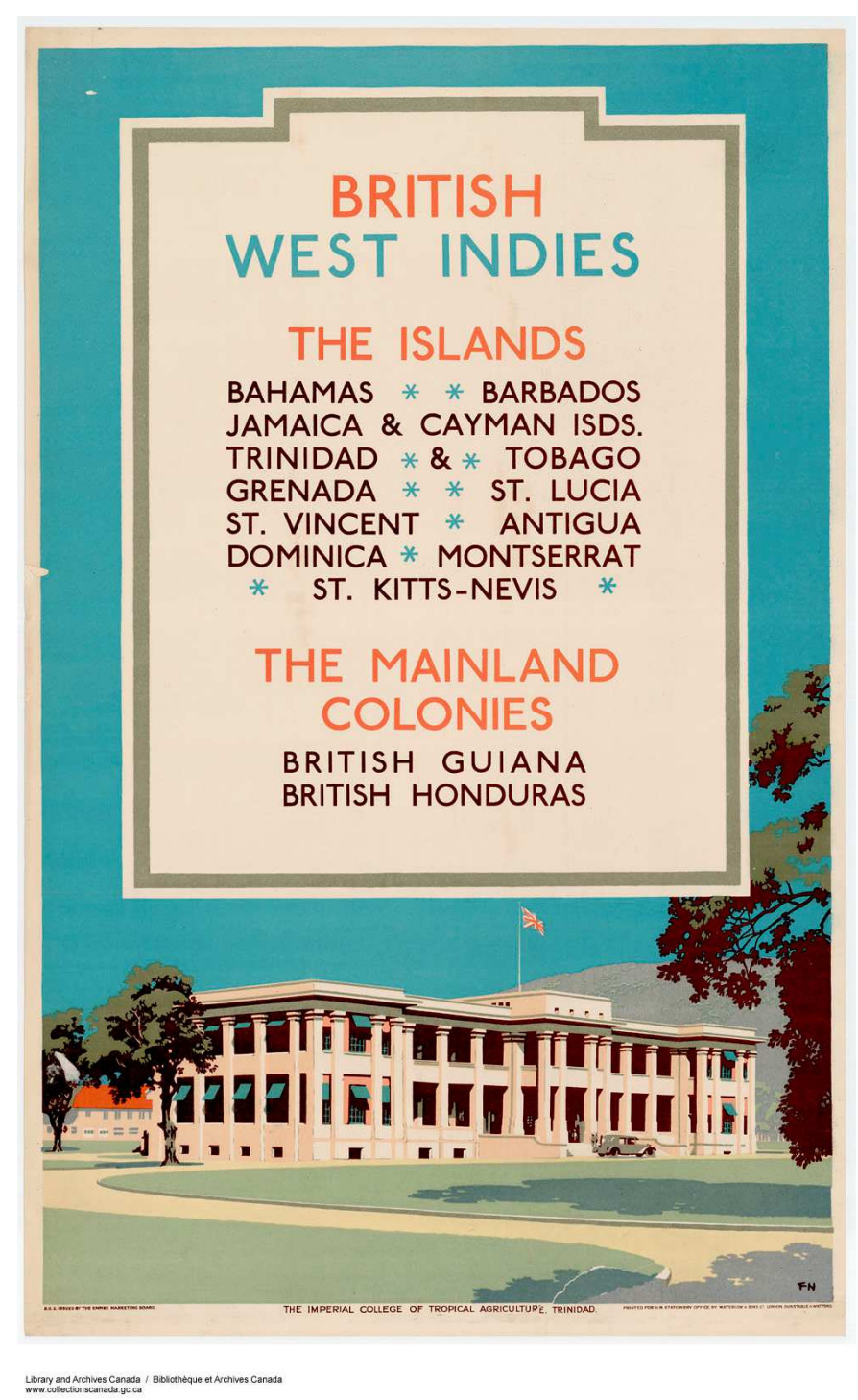

Figure 12. British West Indies: The Imperial College of Tropical Agriculture, Trinidad. Lithograph. 62.5 x 100.7cm, Library and Archives Canada. Ottawa, Ontario. MIKAN 2845004. http://www.bac-

lac.gc.ca/eng/CollectionSearch/Pages/record.aspx?app $=$ FonAndCol\&IdNumber=2845004\#1

The EMB called on plant genetics experts such has Frank Engledow, of the University of Cambridge, to help advise on the ICTA's research work. Cambridge had become a center for Mendelian investigations of animal and plant genetics. Through his studies in hybridization, Engledow had worked to improve yields and disease-resistant 
crops. ${ }^{214}$ The introduction of the sabbatical in 1926 allowed academics like Engledow to apply for research leave for work in the Empire. Though Cambridge academics took advantage of travel to the US and Europe, most of the overseas advisory work focused on the Empire. ${ }^{215}$ Engledow was asked by the EMB to write a report for the ICTA and its needs as a research and teaching institution. Engledow advocated for curriculum based on the Cambridge model, with its expertise in animal nutrition and plant breeding. This ultimately led to greater emphasis being placed on the cultivation of cash crops, as it's work increasingly focused on research into the genetics and cytology of products like sugarcane, cocoa and bananas in order to produce the best yields, quality, and consistency. ${ }^{216}$ The EMB approved funds for a Low Temperature Research Station to be erected to study tropical fruits at the ICTA, which communicated informally with Cambridge ${ }^{217}$ Engledow eventually became one of the Colonial Offices' main advisors on tropical agriculture. In turn, the EMB extended funds to the Cambridge for a library and extensions to the Schools of Agriculture, Botany, and Physiology ${ }^{218}$

\section{$\underline{\text { Tropical Commodities }}$}

Research in the colonies tended to focus on specific tropical commodities, especially ones that were in high demand. Research was needed to investigate the

\footnotetext{
${ }^{214}$ Hodge, Triumph of the Expert, 108.

${ }^{215}$ Heike Jons, "The University of Cambridge, Academic Expertise and the British Empire, 1885-1962," Environment and Planning 48, no. 1 (2016): 101.

${ }^{216}$ Hodge, Triumph of the Expert, 108.

${ }^{217}$ Empire Marketing Board, May 1927- May 1928, 19.

${ }^{218}$ Empire Marketing Board, May 1931 to May 1932, 16-17.
} 
viability of crops in new regions. The Director of the Royal Botanic Gardens at Kew, Arthur Hill, recognized the benefits of cooperation when the EMB approached the Gardens for assistance. With the opening up of more land, the gardens and personnel of Kew were utilized as an important resource for the collecting and studying plant species of economic importance. The EMB grants allowed Kew personnel, including Hill, to travel "in every direction" throughout the Empire to report on conditions and collect specimens. ${ }^{219}$ Kew had long been a central depository for plant varieties. By 1896, Kew had over a million species of plants in its collection and had formed relations with a network of 54 other botanical gardens, 22 of which were in the Empire. ${ }^{220}$ In addition to collecting "plants of economic importance," money from the EMB was also allocated toward the classification of the more than 300,000 specimens that had accumulated from the Dominions and colonies. ${ }^{221}$

H.C. Sampson, of Kew, was appointed to the advisory post of Economic Botanist and he played a key role in advising the EMB about the environments and the commodities of the Empire's colonies. The EMB commissioned Sampson to travel to British Honduras, British Guiana, and the West Indies to investigate the landscape of the regions and their potential for growing additional Empire crops. Sampson illustrated the

\footnotetext{
${ }^{219}$ Funding went toward travels to Australia, New Zealand, Malaya, Ceylon, the West Indies, British Honduras, East, South, and West Africa, British Guiana, Somaliland, Cyprus, and the Solomon Islands, among other countries. Amery, My Political Life II, 351; An Analysis of The Research Grants Policy of the Empire Marketing Board," Report presented to the Imperial Conference Inter-Departmental Committee on Economic Questions (September 8, 1930), 22. BL IOR/L/E/7/1535

${ }^{220}$ Headrick, The Tentacles of Progress, 213.

${ }^{221}$ Empire Marketing Board. Note on the Work and Finance of the Board, 8.
} 
problems that were inherent to growing tropical goods. "Just as when human beings are crowded into big cities there is liable to be a much more serious incidence of disease, so it is with plants," he observed. ${ }^{222} \mathrm{He}$ noted that plant diseases were one of the many larger issues associated with agriculture in tropical regions.

One tropical commodity that was especially vexing was the banana. By the early 1900s, bananas had become less expensive and more widely available, no longer the exotic luxury item that it once had been. The popularity of bananas was also helped by their promotion as a "nutritious and safe" food. ${ }^{223}$ The British Government had previously cooperated with American companies like the United Fruit Company, because products from British Honduras were mainly exported to the United States and United Fruit was the largest North American banana importer. ${ }^{224}$ The Colonial Office was persuaded by the colonial governor to sell land to United below market value and to construct a railway to help export its product. ${ }^{225}$ United's peripheral "corporate colonialism," like that of Britain, was rooted in the rising consumer demand for tropical products.

${ }^{222}$ H.C. Sampson, "The Royal Gardens, Kew, and Empire Agriculture," Journal of the Royal Society of Arts 83, no. 4295 (March 15, 1935): 409.

${ }^{223}$ John Soluri, "Accounting for Taste: Export Bananas, Mass Markets, and Panama Disease," Environmental History 1, no. 7 (July 2002): 393.

${ }^{224}$ This designation was garnered largely through dismantling opposition, thwarting independent marketing of local growers, and government manipulation, practices which resulted in the term "Banana Republics." By 1930 it retained twenty times the 139,000 acres under cultivation in countries throughout Latin America to stave off competition, which it justified my pointing that it periodically needed to move its production sites due to disease and soil exhaustion. Mark Moberg, "Crown Colony as Banana Republic: The United Fruit Company in British Honduras, 1900-1920," Journal of Latin American Studies 28, no. 2 (May 1996): 362.

${ }^{225}$ Ibid., 370 . 
The demand for bananas necessitated large scale monocultural plantations systems. However, this also helped to exacerbate plant disease. When Panama Disease broke out in Latin America and the Caribbean, the Gros Michel banana variety, the principal type grown, faced devastation. The Gros Michel was a sturdy variety but was also more susceptible to disease. ${ }^{226}$ Growing banana crops that were immune to disease while still being robust enough to be shipped long distances required significant research. The EMB provided travel grants, allowing the dispatch of other Kew scientists to travel to Java, Malaya, Siam, and Burma to collect varieties that might be immune to Panama disease; these were quarantined at Kew, before being sent off to the ICTA in Trinidad. ${ }^{227}$ Work at the Imperial College focused on breeding alternate varieties which were immune to the disease. ${ }^{228}$ But such measures ran into difficulties, such as bananas that were disease-resistant but which produced seeds, putting it at a "commercial disadvantage." 229 Attempts to remake a disease-resistant banana were also thwarted by consumers who desired the standard type that they were used to, making new varieties harder to sell. ${ }^{230}$ By the 1950s, the crop would be wiped out almost entirely, making way for the Cavendish variety that is on most store shelves today.

\footnotetext{
226 Sampson, "The Royal Gardens," 409.

${ }^{227}$ Ibid., 409; Empire Marketing Board, May 1929 - May 1930, 14; Empire Marketing Board. Research Grants Committee. Minutes of the $24^{\text {th }}$ Meeting, Hold in the Minsters Conference Room, House of Commons at 3:30 pm on Wednesday the $4^{\text {th }}$ July, 1928 TNA CO $760 / 21$

${ }^{228}$ H.C. Sampson. Report on Development of Agriculture in Trinidad (London: HMSO, 1927), 7.

${ }^{229}$ Soluri, “Accounting for Taste," 398-99.

${ }^{230}$ Ibid., 397.
} 
When Sampson traveled to British Honduras he noted the tenuous nature of production in British Honduras. Despite the agreement that United Fruit would cultivate the land for 25 years as a condition of sale, United pulled out of British Honduras almost entirely by 1920 and the number of crops cultivated fell from 886,881 to 78,867 between 1917 and $1931 .^{231}$ Sampson helped to advise on alternate crops that might be grown in the regions most affected by the disease, envisioning how the region might be kept viable to sell various commodities. He noted there were more prospects in plantains, though a United Fruit Company manger informed him that the quality was currently subpar, he noted that if better cultivation methods could be sought then it might allow better prospects for future. ${ }^{232}$ Sampson also suggested other alternatives products such as cacao and coffee. ${ }^{233}$ Cocoa beans produced in British Honduras were sent to the Imperial Institute in London for study, and samples were sent to local manufacturers to assess their quality and marketability. ${ }^{234}$ The cultivating of tropical commodities required a system of collaboration between many different scientific, institutional, governmental and even corporate interests. This web of influence also illustrates the amount of work that was required to cultivate the commodities that consumers desired.

${ }^{231}$ Moberg, "Crown Colony as Banana Republic," 377.

${ }^{232}$ Sampson, British Honduras, 33.

${ }^{233}$ Ibid., 61.

${ }^{234}$ Ibid., 65 


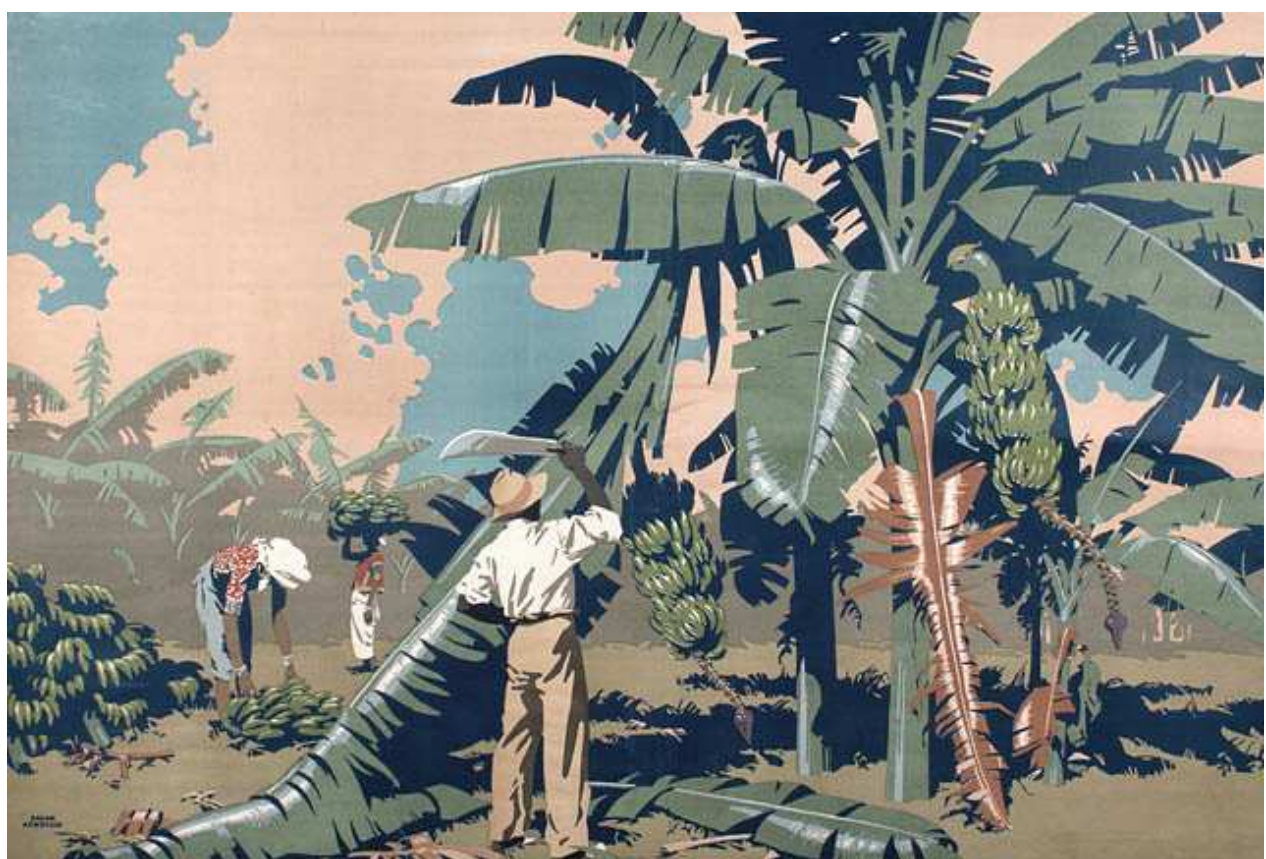

Figure 13. Frank Newbould. Cutting Bananas in Jamaica. Lithograph. 151.6 X $101 \mathrm{~cm}$. Library and Archive Canada. Ottawa, Ontario. MIKAN 2897688. http://www.baclac.gc.ca/eng/CollectionSearch/Pages/record.aspx?app=fonandcol\&IdNumber $=2834294 \&$ new $=-$ $\underline{8586297450096667532}$

Other research on commodities focused on other goods that might able to be grown in the Empire, offsetting foreign production. The Government of Sierra Leone was given funds for establishing an experimental fruit farm to test the cost of growing and shipping bananas and grapefruit. ${ }^{235}$ The Government of the Federated Malay States were given grants to study the drying methods of copra. ${ }^{236}$ Sugar research in Mauritius was funded in order to provide research staff for studies on scientific makeup and

235 Empire Marketing Board, May 1929 to May 1930, 16.

236 The British Empire supplied 40 percent of copra production, mainly from its holdings in the South Sea Islands, British Malaya, and Ceylon. It was valuable for the oil content of the dried coconut meat. It was hoped that further encouragement could increase the percentage even further. "Coconut Palm Products, World Survey. Importance to the Tropics," The Straits Times, March 30, 1933, 19. 
development of sugar. ${ }^{237}$ Other commodities that had been suggested for development included products ranging from Nigerian pineapple and avocados from the West Indies to Indian mangoes and tomatoes from Palestine. ${ }^{238}$ The EMB encouraged research on specific Empire commodities to further explore how they might be developed as an alternative to foreign goods.

The utilization of expert knowledge was used in the colonies to help decide where to allocate funds to best capitalize on the resources of the Empire. However, the cultivation of products, as we have seen, was not simple task. The growing and transport of products throughout the Empire brought ongoing challenges and required the knowledge of experts. It was these ongoing impediments that reinforced the alliance between the state bureaucracy and the scientific world, as both used the other to its advantage. The EMB recognized the inherent challenges to reorienting production efforts toward the Empire, and it's work as a result helped to reinforce connections between government interests and a vast network of scientific authorities.

\section{Conclusion}

The remaking of Empire as an interconnected, globally cooperative Commonwealth became a concept to aspire to, and it required a wide network of collaborators to achieve. Scientific experts were a vital link in the chain that transferred products from fields and farms to consumers' homes. The EMB's focus on science was

${ }^{237}$ With Britain receiving $3 / 4$ of its sugar supplies from non-Empire sources, there was a concerted effort to find new Empire supplies. "Empire Sugar," Brisbane Courier, April 18, 1929, 18; Empire Marketing Board, May 1929 to May 1930, 19.

${ }^{238}$ Empire Marketing Board, May 1931- May 1932, 6. 
paramount to its own focus on the marketing of Empire products. In order to encourage the sale of Empire commodities, it needed to find new methods for acquiring a suitable number of quality goods. With new demands being put on the natural resources of the Empire, this was a continual challenge for scientific experts. A network of scientists was needed to help develop the Empire's resources, reinforcing the reciprocal relationship between the state and scientific communities. The facilitation of such networks was sometimes more successful than others, such as the case of creating more formal chains of research institutes. But the EMB's grants illustrate the facilitation of travel and consultation that helped to fuse and further both bureaucratic and scientific interests.

The EMB sought to use its scientific resources to more fully rationalize the Empire. Faced with economic decline, suffering industries, and a reliance on foreign food, the Empire was conceived of as a lifeline for postwar recovery. The interest in data and efficiency helped by new technologies, attempted to make older arguments modern. In the climate of interwar internationalism, the project of development increasingly took on a different character. While reviving the idea of development in the 1920s, the EMB sold scientific research and Empire development as a cooperative effort that necessitated goodwill and collaboration. Through funding for international research, it hoped to fulfill its mandate. It was conceived of as a humanitarian project in which the entirety of the Commonwealth could be unified, and each part would help the larger whole.

However, these aims also concealed assumption about production in the Empire. Through this chapter's overview of a segment of its efforts, it is evident that the focus of the EMB's research efforts were almost exclusively on the development of primary industries. Though its rhetoric suggested the value of international cooperation and 
improvement, fundamental assumption about Empire development remained the same.

The Empire would be the source of production and the metropole the space for manufacture, reinforcing the underdevelopment of the Empire. In a Parliamentary debate, Amery held that, "it is not very probable, or, indeed, very desirable in the interests of the populations themselves, that industrial development should be unduly accelerated." In the same debate, Ormsby-Gore affirmed that besides Singapore, no other industrial development was envisioned. ${ }^{239}$ The EMB was primarily concerned with developing primary products in the Empire, rather than the modern development that it projected. In this way, it deviated little from development attempts of the preceding century.

The scientific work funded by the Board also helps to illustrate the central role of consumers in the EMB's vision. The EMB hoped to make its work public, to explain its program to buyers, though its success in doing was likely limited. ${ }^{240}$ Publicity for its funded studies stressed that scientific research led to efficiency, which resulted in cheaper food. Waste made food more expensive so, therefore, its efforts helped shoppers get the quality foods they desired at a cheaper price. Research, especially in the tropical regions, was largely funded because it advanced the procurement of Empire goods that were popular among consumers. Changing consumer demands necessitated scientific and technocratic intervention. However, these were not the only associations that the EMB

${ }^{239}$ H.C vol. 227, cols. 1411, 1498-9, April 30, 1929.

${ }^{240}$ To what degree the public was made aware of the EMB's scientific work is debatable. At one of Sampson's later lectures at the Royal Academy of Arts, one audience member noted that the EMB might not have been disbanded, "if the public could have been made interested in it." He noted that it was important for imperial institutions like the Royal Botanic Gardens to appeal to a lay audience and for experts, "to take a little more interest in people who were not scientific." Sampson, "The Royal Gardens," 418. 
forged. The link between producer and consumer was the retail sector, and it was in the second area of its mandate - marketing - that the Board also turned to sell Empire products. 


\section{Chapter 3}

False Advertising: Marketing, Misrepresentation, and the Branding of Empire

In one of its advertisements in the Times, the EMB asserted to readers that, "Every businessman knows that there are two golden rules. The first is that you must make your article well, the second that you must make the well-made article well known." ${ }^{241}$ Taking a cue from the realm of business, the EMB knew that marketing was essential if it was to convince consumers to buy Empire products. However, it faced difficulties on both fronts. As we have seen, procuring good quality articles from the Empire was a difficult task, and one to which significant scientific research was directed. Another of the difficulties encountered by the EMB was in the promotion of authentic "Empire" commodities - as foreign competitors and private labels had developed expertise in both the production and marketing of brand-name goods, which carried with them the reputation of their producers.

Like its scientific aims, a significant part of the EMB's marketing work consisted of research. Through its inquiries, the EMB tried to better understand the missing link between "activities designed to improve production, and activities designed to stimulate the consumer." 242 The EMB worked to compile information about Empire commodities and trade to make market information more legible for producers, distributers, and retailers. The Board also initiated investigations into consumer preferences. Their studies,

241 "Home and Overseas," The Times, June 3, 1927, 9.

${ }^{242}$ Notes on the Proposal for the Appointment of a Marketing Committee, TNA CO $760 / 34$ 
what would become known as market research, involved investigating the products that were preferred by shoppers in order to further understand their impulses and formulate strategies to encourage their consumption of Empire goods.

The Board's civil servants - and the wholesalers, retailers, and other trade members that that it recruited for their knowledge of the industry - attempted to reorient trade away from foreign producers by crafting a brand of Empire. ${ }^{243}$ Quality, availability, cost, and the interests of national industries were all concerns that required attention. In the face of increased competition, and the influx of foreign branded products that consumers could rely on for their quality, it was clear that domestic and Empire producers often fell short. Thus, making products consistent and easily identifiable became a primary goal of their marketing efforts. The EMB worked to create an imperial brand that consumers could readily identify, allowing Empire producers to keep pace with foreign brands. However, this also caused conflicts with domestic producers, blurring the line between imperial and national concerns, and further privileging British interests over those of the Empire. To keep pace with the developments of producers from outside the Empire, the Board's marketing experts worked to improve the manner in which home and Empire goods were produced, packaged, promoted and purchased.

${ }^{243}$ Members of the Marketing Committee included representatives from outside of government and who worked in an advisory capacity based on their expertise. Members included T.W. King, The Director and General Manager of the Civil Service Supply Association - a London department store - Sir Thomas Allen, Director of the Cooperative Wholesale Society, R.S. Forsyth, the London Manager of the New Zealand Meat Producers Board, F.W. Mackinney, the Chief Officer of Supplies for the London County Council, and several other retailers and suppliers. 


\section{Making the Empire Legible}

At the outset, the EMB knew that it faced a considerable problem - consumers depended on goods from outside of the Empire. By the eve of the First World War, Britain was importing 25.3 percent of the world's food products. ${ }^{244}$ The First World War had also raised concerns about Britain's lack of self-sufficiency in food production. With the fall of invisible earnings in the 1920s, Britain's overreliance on foreign food was especially critical. ${ }^{245}$ In order to develop a cooperative trade unit with the Empire, the Board had to work to make the Empire legible, to understand its trade, and how production, retailing, and consumer preferences affected how goods were sold. It was critical for the EMB to find ways to make the purchase of consistent, quality Empire products a reality for consumers.

Understanding that there was a lack of knowledge about the global markets, which reflected a lack of efficiency in production, the EMB moved to discover as much about the circulation of goods as possible. To a certain extent, the investigations furthered by the Marketing Committee were more novel than its other scientific aims. Unlike its scientific research efforts, which largely relied on established universities and research institutes, the field of economic research was still relatively new. The Marketing Committee had to rely on the information garnered from trade and transport organizations or procure new resources for investigation. ${ }^{246}$

${ }^{244}$ David M. Higgins, Brands, Geographical Origin, the Global Economy: A History from the Nineteenth Century to the Present (Cambridge: Cambridge University Press, 2018), 86.

245 Ibid., 94.

${ }^{246}$ Empire Marketing Board, May 1927- May 1928, 21. 
Within the realm of market research, one of the Board's efforts was the creation of a series of "Intelligence Notes" that were designed to serve as a point of reference for producers and traders of certain foods. "The Weekly Fruit Intelligence Notes," for example, were first produced by the EMB in order to consolidate information about products in Britain and the Empire. Such materials were designed to give producers, government departments, and shipping companies a "birds-eye view of the main factors which govern markets and prices." ${ }^{247}$ The Notes gave detailed information on food imports into 25 of Britain's ports and they included data on crops, shipments, and prospects within the Empire, while reports on foreign countries gave Empire producers an idea of their foreign competition. ${ }^{248}$ Similar Notes were also introduced to look at canned and dried fruit, vegetables and dairy products. Acting as its own market research organization, the marketing branch of the Board helped manufacturers, importers, and exporters gain insight into the global food market with the aim of lowering the costs for buyers and sellers of food products. ${ }^{249}$

The EMB also investigated the global production of a range of commodities. The statistical surveys conducted were designed to fill in the gaps of studies that had begun to be undertaken by other organizations, such as the United States Department of Agriculture and the International Institute of Agriculture in Rome, but which hadn't yet reached a larger scale. ${ }^{250}$ The Board was able to compose reports of commodities and the details of their production and trade. The surveys included dairy products, grain crops,

${ }^{247}$ The Empire Marketing Board in May, 1932. CO 1073/171

${ }^{248}$ Part III, 4. BL IEC/Q/18/2

${ }^{249}$ Stephan Schwarzkopf, "The State as Market Researcher," 4-5 ${ }^{250}$ Ibid, 7. 
meat, oils, fruit, and fibers as well as plantations crops - including products such as sugar, tea, coffee, spices, cocoa rubber and tobacco ${ }^{251}$ The compiled reports informed importers and exporters about world production, consumption, and prices worldwide.

Intra-imperial cooperation was sought in the realm of marketing just as it was for its scientific aims. Travel grants were extended to marketing professionals in the hope that increased collaboration within the Empire would help producers and retailers better understand trade concerns. Empire producers and businessmen from the Empire were allotted funds to travel to the Empire and for those in the Dominions, India, and colonies to travel to Britain. Tallents also helped to organize marketing groups that brought together Empire producers of certain goods, like oranges or butter, to explore more fully the entirety of production and distribution through greater collaboration. By further compiling data about the shipping of products from one port to the next, it was hoped that the research would rationalize the process of getting food from its produced location ultimately to the buyer's kitchen.

The Rise of Foreign Competition

${ }^{251}$ EMB. Dairy Produce: A Summary of Figures of Production and Trade Relating to Butter, Cheese, Preserved Milk, Eggs, Egg Products (London: HMSO, 1932); Grain Crops: A Summary of Figures of Production and Trade Relating to Wheat, What Flour, Barley, Oats, Maize, Rice, Rye (London: HMSO, 1932); Meat: A Summary of Figures of Production and Trade Relating to Beef, Cattle, Mutton \& Lamb, Sheep, Bacon \& Hams, Pigs, Pork, Canned Meat (London: HMSO, 1932); Oilseeds and Vegetable Oils: A Summary of Figures of Production and Trade Relating to Copra, Groundnuts, Cottonseed, Linseed, Olive Oil Soya Beans, Sesame Seed, Rapeseed, Palm Kernels, Palm Oil, Whale Oil (London: HMSO, 1932); Plantation Crops: A Summary of Figures of Production and Trade Relating to Sugar, Tea, Coffee, Spices, Cocoa, Rubber, Tobacco (London; HMSO, 1932); Fibres: A Summary of Figures of Production and Trade Relating to Cotton, Wool, Silk, Hemp, Flax, Jute (London: HMSO, 1932); Fruit: A Summary of Figures of Production and Trade Relating to Apples, Pears, Bananas, Citrus Fruit, Grapes, Wine, Raisins and Currents (London: HMSO, 1932). 
Foreign competition was also a primary concern for Empire producers, and it was the raison d'etre of the EMB's marketing work. The interest in scientific management was a common idea in business by the interwar period, reflecting further interest in legibility. With the decline of industry and the rise of foreign competition, the concern for introducing modernization or "rationalization," efforts became a primary concern. Rationalization became a "vogue word," as industries attempted to investigate how British industries might be revived. ${ }^{252}$ This included suggestions for the consolidation of manufacturing to keep pace with increased competition. ${ }^{253}$ Literature of the time stressed the importance of advancements that had been made abroad, such as American mass production and Germany's efficient cartels and trusts. ${ }^{254}$ British rationalization bore some resemblance to Taylorism in the United States, though British industry largely tried to situate itself against the connection. ${ }^{255}$ "Scientific" thinking in the realm of business was also on the rise as research and development departments became part of many larger companies, and consulting firms offering advice on public relations and industrial psychology emerged to manage business's efficiency. ${ }^{256}$ The control and coordination of production, with an emphasis on efficiency, thus drove the industry of the period.

Similarly, in the realm of agriculture, cooperatives had become well-established in some countries as a means of standardizing production and ensuring goods of uniform

252 Julian Greaves, Industrial Reorganization and Government Policy in Interwar Britain (London: Routledge, 2005), 2- 5.

${ }^{253} \mathrm{Ibid}, 4$.

${ }^{254}$ Ibid., 8.

${ }^{255}$ Anthony, Public Relations, 33.

${ }^{256}$ Ibid., 7. 
quality. ${ }^{257}$ Cooperatives generally allowed farmers to improve their economies of scale in production and marketing, leading to higher sale prices. ${ }^{258}$ The benefits of collectivity also included the ability implement technological innovations, access credit, and the obtain assistance during bad harvests or adverse conditions. This became especially important as the market for agricultural products could be especially unstable and subject to volatile highs and lows.

The increased competition from foreign cooperatives began to undermine the success of Empire producers, especially home producers where agriculture continued to struggle. The United States proved to be an emerging challenger to the Empire production of foodstuffs. California was dominated by cooperatives. The citrus industry had united into the California Fruit Growers Exchange and began cooperative farming under the Sunkist label. In order to capture the high end of the European market, to contend with other competitors, they emphasized the quality and consistency of their goods. ${ }^{259}$ Sunkist also benefited from national advertising campaigns, helping to build its quality reputation. ${ }^{260}$ However Europe was still a major trading partner for Britain as well. Spain, as the second largest producer of oranges in the world, next to the U.S., was still Britain's largest supplier. ${ }^{261}$ Despite attempts to push the sale of fruit production in

${ }^{257}$ Higgins, Brands, Geographical Origin, and the Global Economy, 88.

${ }^{258}$ Eva Fernandez, "Selling Agricultural Products: Farmers' Co-Operatives in Production and Marketing, 1880-1930," Business History 56, no. 4 (2014): 547.

${ }^{259}$ Alan L. Olmstead and Paul W. Rhode, "The Evolution of California Agriculture, 1850-2000," in California Agriculture: Dimensions and Issues, ed. Jerome Siebert (UC Berkeley: Giannini Foundation of Agricultural Economics, 2003), 33.

${ }^{260}$ Richard Hawkins, "The Cooperative Marketing of Hawaiian Pineapple, 1908-39," Conference of Historical Analysis and Research in Marketing, May 17-20, 2007, Durham, NC, 256.

${ }^{261}$ EMB, Oranges, 13; EMB, Fruits, 31. 
Empire regions, such as Palestine and South Africa, foreign goods still continued to supply much of Britain's food supply.

The emergence of other goods, like canned food, also helped to shift world food production. Canning, another booming technological advancement, helped to transcend time, space, and nature by overcoming the limitations of seasonal cultivation. Canning helped to also facilitate the globalization of food, while still emphasizing the importance of its place of production, as Simon Naylor has put it, "simultaneously locating and dislocating: attaching and detaching its contents to particular places around the world."262 The Hawaiian pineapple industry led by figures such as James Drummond Dole helped to streamline production and canning technologies to ensure quality. The pineapple industry was also the first to adopt nationwide co-operative advertising of its product in 1908, with producers collectively extolling the virtues of its "Hawaiian" product. ${ }^{263}$ Canning brought the products of one part of the world to the other and, at the same time, their place of origin became a marketing tool through the association of particular regions with quality.

The EMB was aware of the advancing efforts in marketing. Its Marketing Subcommittees, such as the Food Committee - being from among the retail trade - had knowledge about foreign products and were able to advise the EMB on how to best counter foreign marketing efforts. They noted that many Empire products did not meet the quality of foreign goods, especially American ones. They observed that labels on

\footnotetext{
${ }^{262}$ Simon Naylor, "Spacing the Can: Empire, Modernity, and the Globalisation of Food," Environment and Planning 32 (2000): 1636.

${ }^{263}$ Hawkins, "The Cooperative Marketing of Hawaiian Pineapple," 256.
} 
Empire canned fruit were "not so attractive as the American production," 264 noting a need to improve the appearance and labeling of the existing Empire products in order to better compete with those from abroad. Committee members also noted that there was "no possibility of competing on commercial lines with the American trade in canned peaches." ${ }^{265}$ They similarly noted that Empire-produced goods such as Malayan pineapple were not of the same quality as its Hawaiian rivals. ${ }^{266}$ Empire canned fruit was not always of the same quality as foreign, as the Committee acknowledged, and they noted that packing and grading improvements would be necessary in order to compete with foreign products. The advertising of such as Empire canned fruit (Fig. 14) was, thus, a marketing offensive aimed at combating higher quality foreign goods.

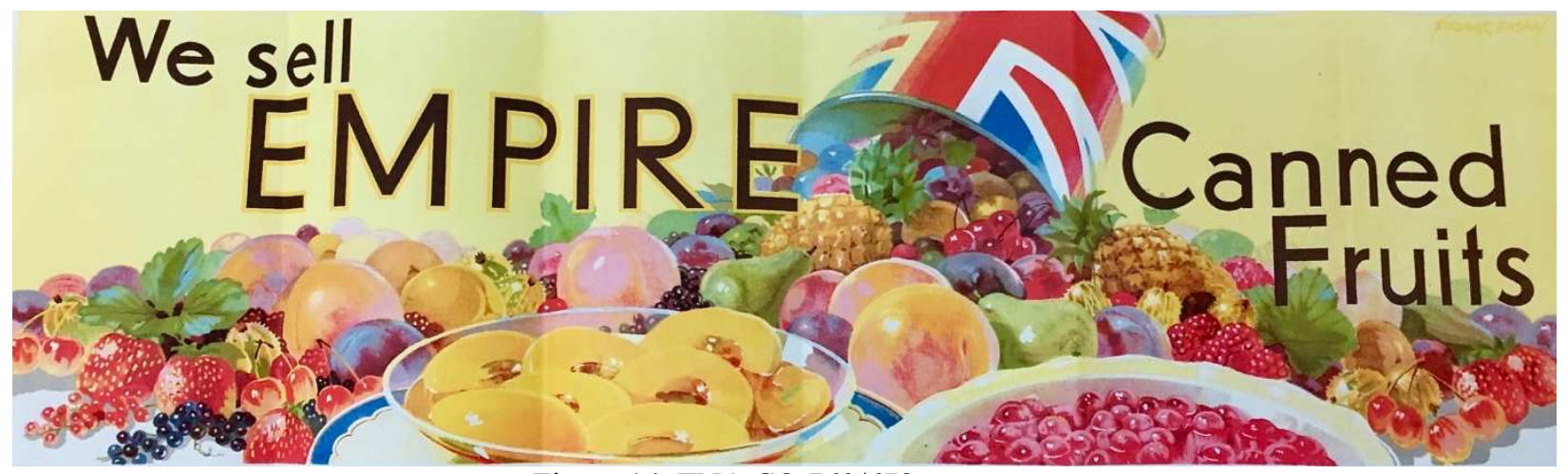

Figure 14. TNA CO 760/672

${ }^{264}$ Food Products Committee. Record of Discussion at the Third Meeting of the Committee Held on Wednesday, July $16^{\text {th }}, 1930$ at 3 p.m. CO 760/11

${ }^{265}$ Empire Marketing Board. Marketing Committee. Food Products Committee. Record of Discussion at the Third Meeting of the Committee Held on Wednesday, July, $16^{\text {th }}$, 1930 at 3pm. CO 760/11

266 "Empire Marketing Board. Marketing Committee. Food Products Committee. Minutes of the Twelfth Meeting Held on Wednesday, February $25^{\text {th }}$, 1931 at 3:30 om at the British Industries Fair, Olympia, London. CO 760/11 
The EMB faced increased competition from foreign products and their advancing marketing tactics. American advertising firms such as J. Walter Thompson had expanded into European markets, including Britain. J. Walker Thompson held contracts with larger U.S. firms such as Lever, GM, Kellogg's, Wrigley, and Gillette. ${ }^{267}$ But it also included other companies that more directly competed with Empire products, like Californian SunMade Raisins which competed with products from Australia, as the largest vine-fruit producer in the Empire. ${ }^{268}$ Sun-Maid Raisins were produced by the Californian Associated Raisin Co., which built a recognizable brand symbol through the Sun-Maid raisin girl with her iconic red bonnet. JWT was able to use continuous brand and logo designs to help reassure consumers of Sun-Maid's quality and consistency.

The size of firms like JWT allowed it to undertake more large-scale marketing efforts. It became the first firm in Britain to offer market research as part of its larger campaigns, and it conducted surveys on consumer behavior by the mid 1920s to better understand consumer demands and preferences. ${ }^{269}$ Through its market research, JWT had learned that most housewives only bought raisins for their Christmas puddings, so brand was not so important to them; instead, Sun-Maid introduced products like raisin bread, which would create demand for raisins year-round. ${ }^{270}$ The EMB's push to sell the

${ }^{267}$ Stephan Schwarzkopf, "Market Research, Product Innovation, and the Creation of Brand Loyalty in Britain and the United States in the Interwar Years," Journal of Macromarketing 29, no. 1 (2009): 10.

${ }^{268}$ Kaori O’Connor, “The King's Christmas Pudding: Globalization, Recipes, and the Commodities of Empire," Journal of Global History 4, no. 1 (2009): 140.

${ }^{269}$ Schwarzkopf, "Market Research," 9-10.

${ }^{270}$ Stefan Schwarzkopf, "Classes to Masses: How Advertising Agencies Responded to the Challenges of the Mass Market in Interwar Britain," Paper given at the Economic History Society Annual Conference, University of Reading, March 31-April 2, 2006, 2. 
"brand" of place, to counter such foreign marketing, was reflected in its ongoing marketing and publicity attempts demonstrating the bounty of the Empire (Fig. 15). It was hoped that such a conceptualization would help to sell Empire products at a time when Empire producers were forced to compete with foreign brands that had built a reputation for quality among consumers.

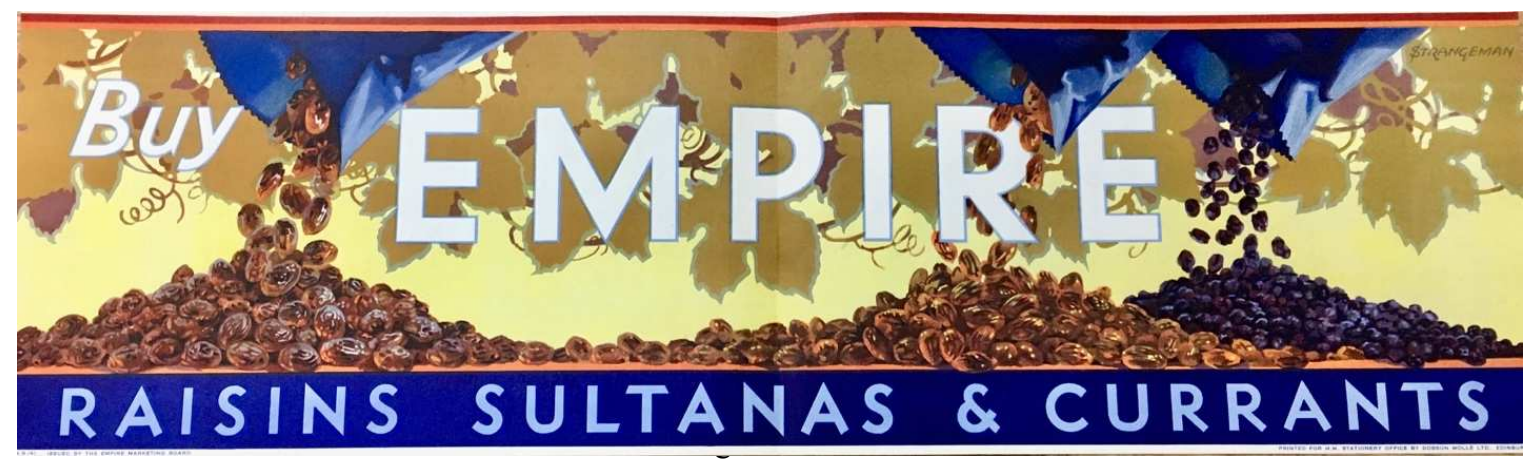

Sir Benjamin Morgan, the chairman of the Empire Producer's Organization, noted that California had gotten food production down "to an unimaginably fine art," with "the finest packers and graders in the world," allowing them to supply food year-round and ensuring that "they never lose in the British market the good will of their product or their label." ${ }^{271}$ California raisins and oranges, like Hawaiian pineapples, held an increasing share of the market for fruit products, with advanced technologies in packaging, as well as innovative branding, design and advertising campaigns. Foreign goods, especially emerging brand-named American products, proved a serious challenge to the production

271 “Empire Products.” The Sydney Morning Herald, July 20, 1928, 12. 
of Empire products and it necessitated increased efforts to sell Empire products, be they raisins from Australia, oranges from South Africa, or Malayan pineapples.

\section{The Butter Battle and the Merchandise Marks Acts}

Though American producers were emerging as a major competitor, Europe still produced much of the goods that found their way into British store shelves. One case that illustrates another instance of competition and the rise of branding among producers, and their limitations, was the dairy industry of Denmark. During the fierce food debates in Britain during the Victorian and Edwardian periods, Denmark had been an anomaly. It was usual in that it was one of few countries that retained duties on manufactures, but that maintained free trade in agricultural products. Tariff reformers in Britain had looked to Denmark as an example of how rural and urban interests might both be protected. ${ }^{272}$ Denmark had taken a different approach to the "grain invasion" brought on by the institution of free trade. While Britain largely relied on the import of food, Denmark reoriented their economy to focus on agricultural export, especially of dairy and bacon. By 1913, 40\% of the workforce continued to work in agriculture in Denmark while in Britain, due to the decline in its agricultural sector, it had shrunk to $12 \%{ }^{273}$ By the 1890 's, Denmark's cooperative farming model had helped it to overtake Irish imports, traditionally Britain's largest supplier. ${ }^{274}$

${ }^{272}$ Edmund Rogers, "A 'Small Free Trade Oasis'? Agriculture, Tariff Policy, and the Danish Example in Great Britain and Ireland, c. 1885-1911," Scandinavian Journal of History 38, no. 1 (2013): 54.

${ }^{273}$ Ibid., 45

${ }^{274}$ Ibid. 
What helped Denmark was not only its cooperative farming model, but its ability to successfully brand its national product. The introduction of a common brand of production, "Lurbrand," helped to unify 1400 independent dairies under a single recognizable name that symbolized high quality. ${ }^{275}$ The Merchandise Marks Act (1887) had been passed in Britain to help prevent the misrepresentation of goods. However, loopholes to this legislation were prevalent. Imported goods had to be labeled upon entry into the U.K., but tickets and labels could be removed. Products like butter were imported in bulk and assembled into packets by retailers who divvied up supplies based on customer's desired weight. Only the grocer knew the place of origin, which it was not required to indicate to shoppers. ${ }^{276}$ Butter was the second most adulterated product imported into Britain. ${ }^{277}$ The Danish dairy industry utilized the British legal system to prosecute any retailer that misrepresented Danish butter, helping Lurbrand uphold its reputation. This helped it to further build a brand identity based on quality, which was desired even thought it was often more expensive than other types. ${ }^{278}$

Similar efforts also were put in place by Empire producers in order to keep pace with efforts such as those of Denmark. For New Zealand, the mother country was its largest market for butter, absorbing 93 percent of its production by weight between 1923

\footnotetext{
${ }^{275}$ David Higgins and Mads Mordhorst, "Reputation and Export Performance: Danish Butter, Exports and the British Market, c. 1880-1914," Business History 50, no. 2 (2008): 186.

276 "David M. Higgins and Brian D. Varian, "'Money Talks - Give Yours an Empire Accent:' The Economic Failure of the Empire Marketing Board, 1926-1933" paper presented at the Economic History Society Conference, Queens University, Belfast Ireland (April 5-7, 2019).

${ }^{277}$ Ibid., 193

${ }^{278}$ Higgins and Morthorst, "Reputation and Export Performance," 199. 
and $1936 .{ }^{279}$ New Zealand similarly used a brand name to market its own production under the name "Anchor" which was registered in Britain as a trademark in 1905 by the New Zealand Dairy Association. Like Denmark, New Zealand had also embraced a cooperative system, and integrated grading standards for their products. New Zealand producers' boards sought to capitalize on cultural meanings and associations through its adverting, a methodology that was also used in parallel by the EMB. The Anchor brand sought to illustrate the similarities between New Zealand the and Britain, with advertising emphasizing the "home-like" nature of rural New Zealand and its similarities to rural Britain $^{280}$

The introduction of cheaper alternative products, like margarine, also caused concerns for dairy interests around the globe. The quality of Danish butter allowed it to stay competitive, while other countries, like Ireland, faced more direct competition and struggled to catch up. Cooperative expansion was slower in the Irish Free state than in Denmark, and after WWI, other Empire producers like Australia and New Zealand. ${ }^{281}$ The influx of cheaper margarine to the British market led to a number of regulatory measures on the production and marketing of margarine, usually at the behest of the dairy industry, both domestically and around the world. ${ }^{282}$ Pressures on the state to regulate

${ }^{279}$ Felicity Barnes and David M. Higgins, "Brand Image, Cultural Association and Marketing: 'New Zealand' Butter and Lamb Exports to Britain, C. 1920-1938," Business History (2007), 4

${ }^{280}$ Ibid., 13.

${ }^{281}$ Eva Fernandez, "Selling Agricultural Products: Farmers' Cooperation in Production and Marketing, 1880-1930," Business History 56, no. 4 (2014): 551.

${ }^{282}$ Denmark, unsurprisingly, was one of the first to put regulatory legislation in to practice, including requiring that warning signs be put in shops selling margarine and also preventing the color of the product to look like butter. In Canada, except for a brief period after WWI, margarine was banned entirely between 1886-1949. During the US 
margarine was portrayed as an appeal to "public interest" though it also helped the interest of producers. ${ }^{283}$ It also forced Empire producers to increase quality of their good to keep pace with the quality and marketing standards that had been set by foreign competitors.

Catching up to foreign competition, however, was complicated by fact that the origins of goods were often not indicated at the point of sale. Lengthy disputes between manufacturing and other interests prevented any agreement on requiring a label of origin to be displayed on products sold in Britain. ${ }^{284}$ An expanded Merchandise Marks Act (1926) was passed which allowed for petitions to be made to a Standing Committee if a given industry believed that they were being unfairly affected by misrepresentation. Problems such as butter blending was a concern, as instances were reported where domestic butter had been mixed with foreign types and marketed as an Empire product, which was perceived as harming the reputation of home production. ${ }^{285}$ The British Dairy

\footnotetext{
"margarine wars" dairy interests succeeded in requiring taxes and licensing fees for producers and sellers of margarine. Seven states banned it outright while Vermont, New Hampshire, and South Dakota required that margarine sold in the state had to be colored pink. See Marcus Lampe, and Paul Sharp, "Greasing the Wheels of Rural Transformation? Margarine and the Competition for the British Butter Market," The Economic History Review 67, no. 3 (2014): 787; Rebecca Rupp, "The Butter Wars: When Margarine Was Pink," August 13, 2014. National Geographic. https://www.nationalgeographic.com/people-and-culture/food/the-plate/2014/08/13/thebutter-wars-when-margarine-was-pink/; Kat Eschner “The 1870's Dairy Lobby Turned Margarine Pink So People Would Buy Butter," May 23, 2017. Smithsonian https://www.smithsonianmag.com/smart-news/1870s-dairy-lobby-turned-margarine-pinkso-people-would-buy-butter-180963328/

${ }^{283}$ Michael French and Jim Phelps Cheated Not Poisoned? Food Regulation in the United Kingdom, 1875-1938 (Manchester: Manchester University Press, 2009), 64-65.

${ }^{284}$ Higgins, Brands, Geographical Origin, and the Global Economy, 155.

285 "Foreign Butter Sold as English." The Times. February 14, 1930, 9.
} 
Farmers Association and the British Empire Producers' Organization argued that it was impossible for consumers to tell Home or Empire butter from those of foreign and pushed for a system of labeling. ${ }^{286}$ However, the idea was opposed by by grocers and retail organizations who did not want to adhere to further regulation. Retailers were concerned that such legislation would leave them liable to prosecution.

The Committee ruled that due to the potential for misrepresentation, butter was required to be labeled with place of origin. The committee chair noted that, "It was preventing the free exercise by the public of a preference for home and Empire-produced foodstuffs, was misleading to shoppers generally, and highly detrimental to the ultimate interest of British dairy farmers." ${ }^{287}$ However, enforcement of Marking Orders was a larger problem. The duty of enforcing Marking Orders was given to local authorities and their level of enforcement varied, as violations of the Orders were reported even after the measure was passed. ${ }^{288}$ Industries could petition for redress if they felt their industry to be the victim of misrepresentation, but there was still no overarching legislation that required that the place of origin be labeled on all goods sold in Britain.

${ }^{286}$ Barnes and Higgins, "Brand Image, Cultural Association and Marketing," 19

287 "Foreign Butter," The Times, October 29, 1930, 11.

288 “Marking of Imported Foodstuffs," The Times, February 27, 1933, 18. 


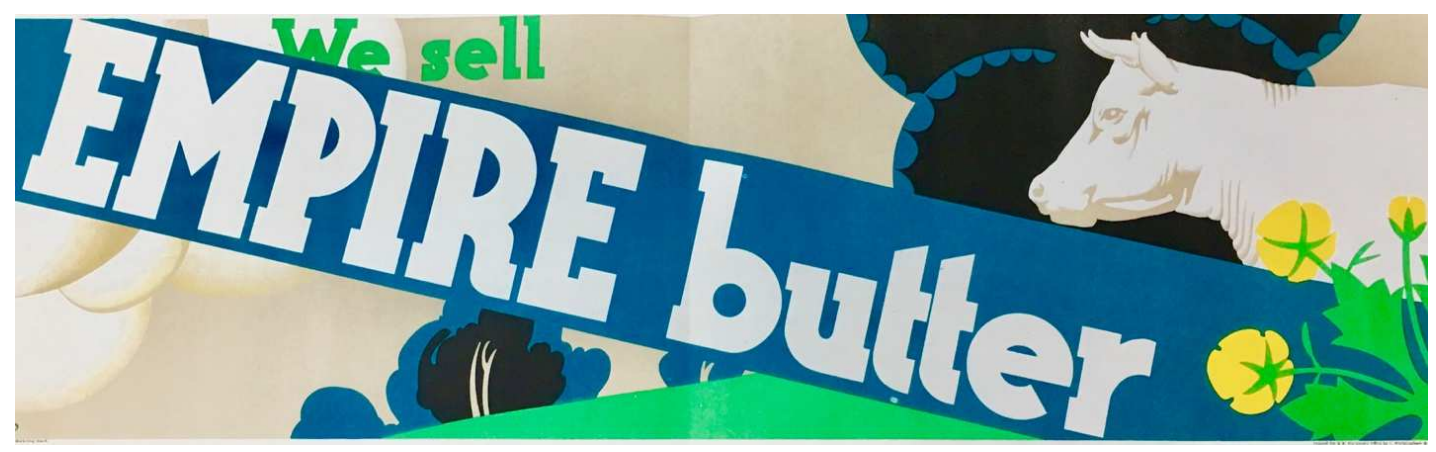

Figure 16. TNA CO 760/672

At other times, however, petitions were rejected. Similar petitions for a Marking

Order were attempted by the Indian Tea Association, the South Indian Association, and the Ceylon Association in 1929. Opponents such as the Tea Buyers Association and the Federation of Grocers argued that much of the tea imported into the UK was blended and sold under brand names, making labels of origin too difficult to regulate. ${ }^{289}$ It was common to blend Indian or Ceylonese tea with that from Java or Sumatra to maintain a certain quality or price, with Chinese blends being the most expensive. By 1930, foreign tea represented around $30 \%$ of tea imports. ${ }^{290}$ Blending was common in many industries, not only butter and tea but with other products like cocoa, coffee, and flour. ${ }^{291}$ Opponents argued that brand named blends carried a certain reputation and labeling them as "Empire" or "empire and Foreign" would hurt the reputation of companies within the

\footnotetext{
289 Barnes and Higgins, "Brand Image, Cultural Association and Marketing," 21. ${ }^{290}$ EMB, Plantation Crops, 24.

${ }^{291}$ Managers Reports on "Buy British" Campaign, 3. 23 February 1932, TNA CO 758/94/6; The Committee noted that millers, especially in smaller towns, used flour from various sources as domestically-produced wheat was often more expensive. And bakers were often traditionalists, and "not disposed to experiment with unaccustomed blends." "Minutes of the Twenty-Third Meeting Held on Wednesday, December 2, 1931 at 2:15 p.m. in the Board's Conference Room TNA CO 760/11
} 
industry, and for that reason the petition was rejected. ${ }^{292}$ The Indian Tea Association later turned to the EMB to help find ways of distributing an Empire tea on a voluntary basis through its connections with the tea and grocery trades (Fig. 17). ${ }^{293}$ The labeling of home and Empire goods was thus inconsistent, blurring the lines between foreign, Empire, and domestic goods, and making the need for a recognizable brand all the more important. Empire products would not reach consumers if their origins were unclear. Requests for labels of origin, when they were approved, were not always enforced, and sometimes they were rejected outright. Such products always competed with foreign brands and the quality that they represented. Thus, the EMB's attempt to encourage consumers to "Buy Empire," was not always as simple as it appeared.

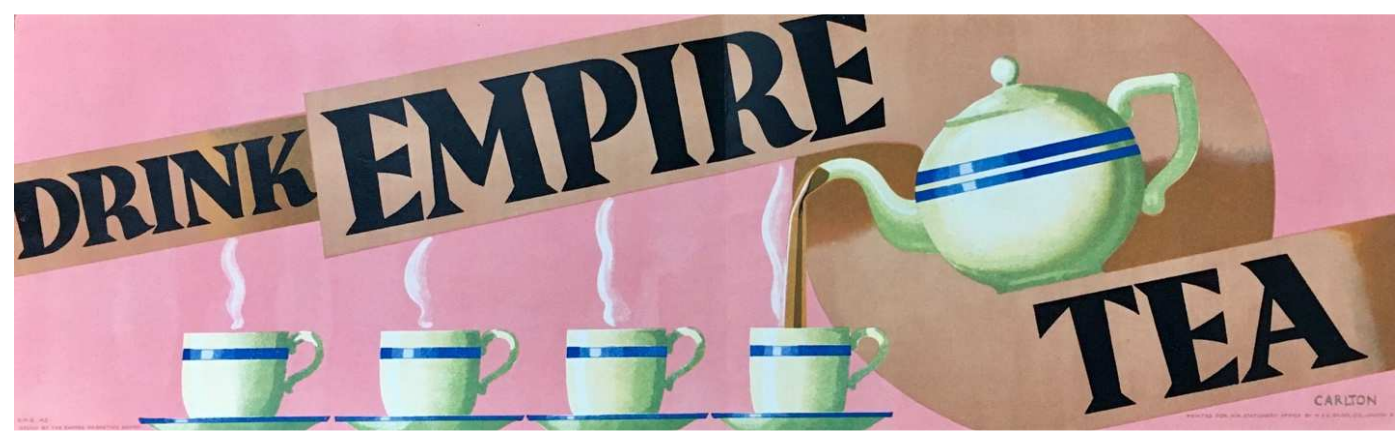

Figure 17. TNA CO 760/672

\section{Empire Research and Development}

The EMB's interest in compiling information also centered around investigating consumer demands. Stefan Schwarzkopf has illustrated that contemporary study of

\footnotetext{
${ }^{292}$ Barnes and Higgins, "Brand Image, Cultural Association and Marketing, 21.

${ }^{293}$ Marketing Committee. "Report of the Empire Tea Subcommittee," TNA CO 760/34
} 
market research has often only involved investigation into the market itself, without looking to the marketing work conducted by government organizations. He has noted that the emergence of bureaucratic agencies, like the EMB, coincided with the development of a civil service that attempted a more engaged agenda, as understanding public opinion became more imperative. ${ }^{294}$ The EMB utilized private sector resources and methods to more fully investigate consumer preferences to help understand consumers and strategize on how to influence their purchasing habits.

Given the stiff competition of products like butter, the EMB moved to initiate market research studies to better study consumer demands. Its butter study examined 2,918 shops in 18 towns, not only in London but other major cities- including Bristol, Birmingham, Liverpool, Manchester, Bradford, Edinburgh, and Glasgow. ${ }^{295}$ The studies noted the sale of butter from New Zealand, Australia, and the Irish Free State versus other foreign sources, such as those from Denmark and Argentina. While London carried more Empire products than foreign, other areas showed a higher proportion of imports from Denmark, especially in the north, even though it was more expensive than others types. ${ }^{296}$ The studies concluded that the purchase of products largely had more to do with the port of entry - with Australia and New Zealand butter entering from London ports, Irish entering from western ports, and European products arriving from ports to the east than other contributing factors. ${ }^{297}$

${ }^{294}$ Stefan Schwarzkopf, "Market, Consumers, and the State," 2

${ }^{295}$ EMB. The Demand for Empire Butter: Report of an Investigation by the Economic Section of the Empire Marketing Board in to the Retail Marketing of Butter in the United Kingdom (London: HMSO, 1930), 8-9.

${ }^{296}$ Ibid., 28.

${ }^{297}$ Ibid., 49. 
Other long-range studies were conducted over several years. By canvasing retailers over a longer time frame, it was hoped that the Board could gain better insight about how well empire products sold. Surveyors interviewed retailers to find out information about stocks, sales, and prices. They made note of which stores stocked which types of products, and at what time of year certain products were more likely to be stocked than others. Further studies showed that English butter was often the most expensive but was rarely stocked in the shops surveyed ${ }^{298}$ The studies overall showed mixed results. Though there were some increase in the sale of Empire products, Denmark still made up almost 60 percent of imported butter, signaling one instance of sustained foreign preference. ${ }^{299}$ The EMB would also commission reports on other goods, such ranging from cheese to canned vegetables to better understand consumers demographics and preferences.

In order to push the sale of empire products, the EMB also investigated which Empire products might in the future be substituted for foreign products. The Marketing Committee, with the cooperation of empire governments, participated in experimental consignments to investigate product development. In one such instance, the government of Palestine sent crates of grapes to Britain for study on how well they could be transported. Similar studies and reports were supported by other governments and included studies ranging from Kenyan pineapples to Australian plums to Canadian

${ }^{298}$ EMB. Further Changes in the Demand for Butter July 1928 and July 1931: Report of an Investigation by the Economic Section of the Empire Marketing Board into the Retail Marketing of Butter in Nottingham (London: HMSO, 1932), 19.

${ }^{299}$ Ibid., 20. 
peaches. ${ }^{300}$ By investigating technical problems, it was hoped that new products would be able to be exported throughout the Empire. The experiment in governmental product development was also assisted by a Fruits Committee, made up of wholesalers, brokers, producers' organizations from abroad, and members of the scientific community. In addition, a Food Committee, made up of members from the wholesale sector, was given the more general task of surveying the state of affairs and investigating which Empire foods could potentially be substituted for Empire sources. ${ }^{301}$ Some products were also sent to retailers to judge on their quality and potential for sale on the market. ${ }^{302}$ The EMB's work to compile data, from the study the supply of shipments and storage to the types of products that consumer preferred, were all gathered to help facilitate the sale of products from Britain and the Empire.

\section{National Mark Campaign}

Even though the EMB was founded in order to sell Empire products, opposition emerged among domestic producers who believed that advertising Empire foodstuffs hurt the struggling agricultural industry at home. The National Farmers Union (NFU), a powerful political pressure group, had voiced its opposition to schemes involving the marketing of Empire produce. ${ }^{303}$ As a result, it was decided that British food would have to be treated the same as Empire and had to be promoted alongside it. Board members were always mindful that 'the Home farmer from Great Britain's point of view must

\footnotetext{
${ }^{300}$ Empire Marketing Board, May 1927- May 1928, 26.

${ }^{301}$ EMB Marketing Committee Notes, TNA CO 760/34.

${ }^{302}$ Empire Marketing Board, May 1931- May 1932, 97.

303 Atkins, "Food and the Empire Marketing Board in Britain," 5.
} 
inevitably...come before the interest of the primary producers in the Dominions and colonies. ${ }^{304}$ Like some of its scientific research, aimed at stimulating demand for products like milk, marketing home agriculture was seen as a way to help the struggling agricultural sector. Such concerns meant a need to provide home producers with marketing priority over those from abroad, significantly limiting and reconfiguring the EMB's initial goals.

In 1922 the Linlithgow Committee, appointed to study the state of Britain's food supply, had pointed out the need for British farmers to develop more of a "marketing sense" and it emphasized the need for a standardization and grading system in a similar vein to what foreign countries had accomplished. They also emphasized the need for cooperative structures to maintain standard production and quality. ${ }^{305}$ The Ministry of Agriculture and Fisheries recognized the benefits that labeling products with country of origin could provide. However, the MAF advised that due to the varied quality and grading of British production the adoption of a national mark was potentially problematic and could backfire, forcing consumers to seek out Empire and foreign products. ${ }^{306}$ The movement toward creating a national campaign for British goods was, then, concerned with illustrating quality to shoppers, as attaching a national association to goods could go awry if goods were subpar.

With its hands tied, the EMB made grants to the Ministry of Agriculture and Fisheries to create a National Mark marketing scheme for domestic products. ${ }^{307}$ The

\footnotetext{
304 Ibid., 144.

${ }^{305}$ Higgins and Varian, "'Money Talks," 18.

306 Ibid., 19.

${ }^{307}$ National Marks Scheme. HC Deb, April 17, 1930, vol. 237, cc 3083-4.
} 
Agricultural Produce (Grading and Marketing) Act of 1928 enabled the promotion of the National Mark marketing scheme to help standardize domestic produce, helping it to catch up to its foreign rivals. Items ranging from eggs and fruit to cider and flour that were produced in Britain were given special National Mark labels to distinguish them from other products (Fig. 18). Specialized packing facilities were established to facilitate the voluntary scheme as well. Products were required to contain 100\% Empire-sourced materials and standardization and grading were put into effect. A similar scheme was also set up to create a Scottish National Mark program. Organizations such as the General Purposes Committee of the Federation of Grocers Association, which represented 40,000 retailers, agreed to give the scheme its full support. ${ }^{308}$ The National Mark appealed to shopper's patriotic sensibilities, encouraging the consumption of national products at the expense of foreign.

${ }^{308}$ Empire Marketing Board, May 1928- May 1929, 18. 


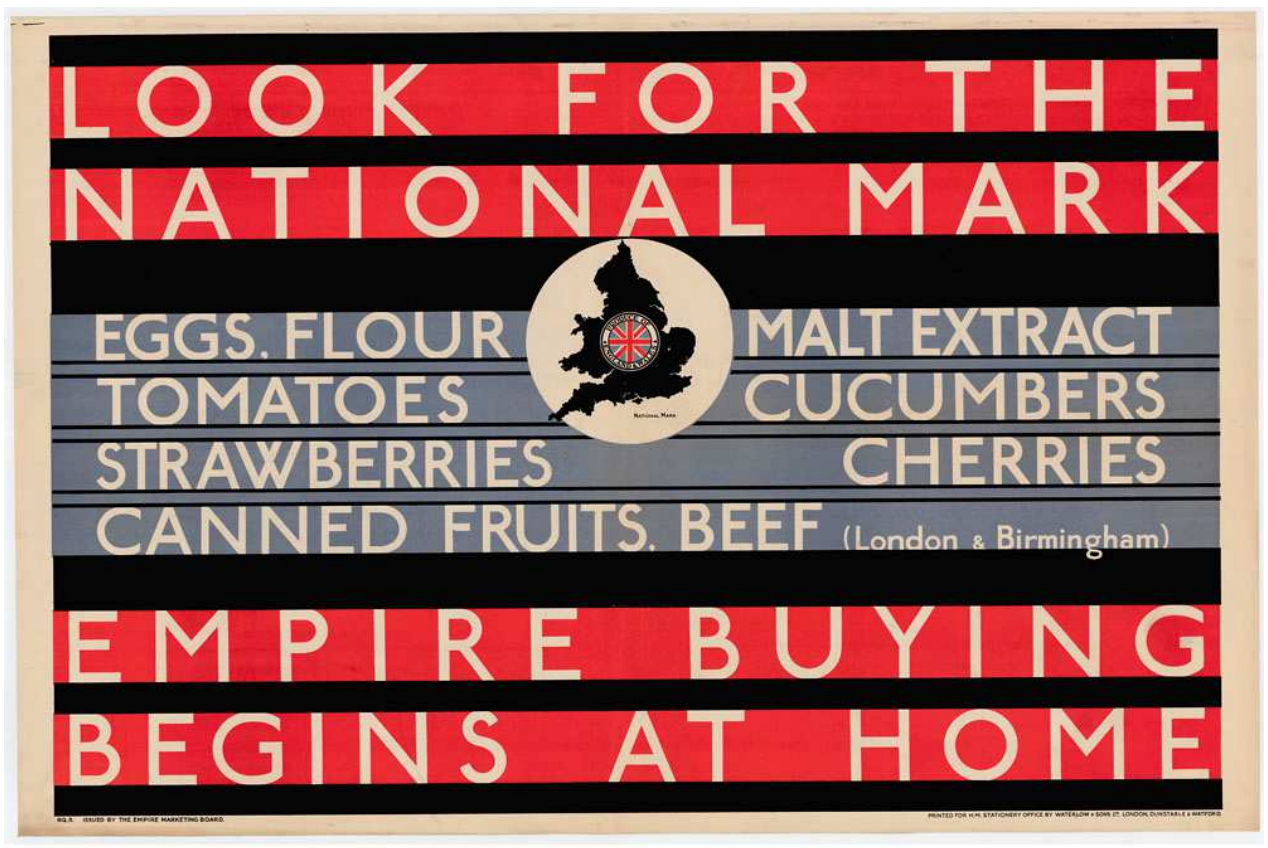

Library and Archives Canada / Bibliothéque et Archives Canada
www. collectionscanada.gc.ca

Figure 18. Empire Marketing Board. Look for the National Mark - Empire Buying Begins at Home. Lithograph. 151.2 X $101.1 \mathrm{~cm}$. Library and Archive Canada. Ottawa, Ontario. MIKAN 2845333. http://www.bac-

lac.gc.ca/eng/CollectionSearch/Pages/record.aspx?app=fonandcol\&IdNumber=2845333\&new=$\underline{8586297422372191532}$

Appeals were made to consumers that they should not forget home goods in their pursuit of Empire products. National Mark labels affirmed that "Empire buying begins at home," illustrating that buying British products was the first step in improving Empire trade. The marketing in the Times, similarly advertised that "Home is best," encouraging customers to buy locally-produced products. ${ }^{309}$ The push to encourage consumers to buy at home also reaffirmed the hierarchy of producers in that British products were ultimately emphasized over Empire and foreign commodities. Walter Guinness, the

309 “Empire Marketing Board,” The Times, November 5, 1929, 11. 
Minister of Agriculture, illustrated that home goods were, however, less desired than Dominion and foreign products which necessitated their promotion.

"Distributors in our large towns and cities are accustomed to handle imported supplies which are available in bulk and conform to the recognized standards of the country of origin; they are also familiar with the national grade marks of various kinds that are employed by Dominion and foreign countries. Dependable service, it must be admitted, has made imported produce easy to handle and easy to sell; it is the frequent lack of it which has discouraged many distributors from helping home produce at all. ${ }^{~} 310$

The National Mark, as a symbol of quality and standardization, was an attempt to improve the perception of home goods. If they home goods were to win the confidence of consumers, they would have to be of better quality.

Some manufacturers were more hesitant in adopting the program, however. Food processors were afraid of increased costs associated with such a scheme due to more expensive raw materials. Similarly, producers such as Food Manufacturer's Organization, especially in reference to products such as jams, feared that the National Mark scheme would impose higher production standards than those they were currently used to. ${ }^{311}$ The use of the label also came with certain regulations, such as being inspected by the Ministry at the place of production and the stores that they were sent to, which some objected to. ${ }^{312}$ Some producers preferred to keep their own trademarks because of their reputation, though trademarked goods with the word "national" in their name were permitted to keep their label, leading to further confusion. For some producers, the push

310 The Right Hon. Walter Guinness. "The National Mark." The Times. February 1, 1929, 13.

${ }^{311}$ French and Phillips, Cheated Not Poisoned, 138.

312 "Graded Produce." The Times, November 20, 1928, 11. 
for a home good advertising system proved too restrictive while others, welcomed it as a way to manufacture demand for a struggling industry.

The National Mark was a symbol to consumers of improved quality, giving consumers the assurance of knowing where their products originated from. Even so, the system was voluntary and not all industries chose to submit to its regulations. Given the lack of regulatory measures to assure that Empire products would be labeled as such, much of the responsibility for ensuring the source of products was passed to consumers. Customers were encouraged to ask retailers where their products came from in order to ensure its sources of origin (Fig. 18). In order to sell Empire products, the EMB had to also assure consumers that Empire goods were, in actuality, from the Empire. If consumers had to ask for Empire goods, it was likely not always clear which products were Empire and which ones were not. The appeals to display and ask for goods reflected the fact that, other than National Mark products, there was largely no mechanism to ensure that goods were labeled correctly. In the face of ongoing competition, the marketing of goods continued to run into challenges. 


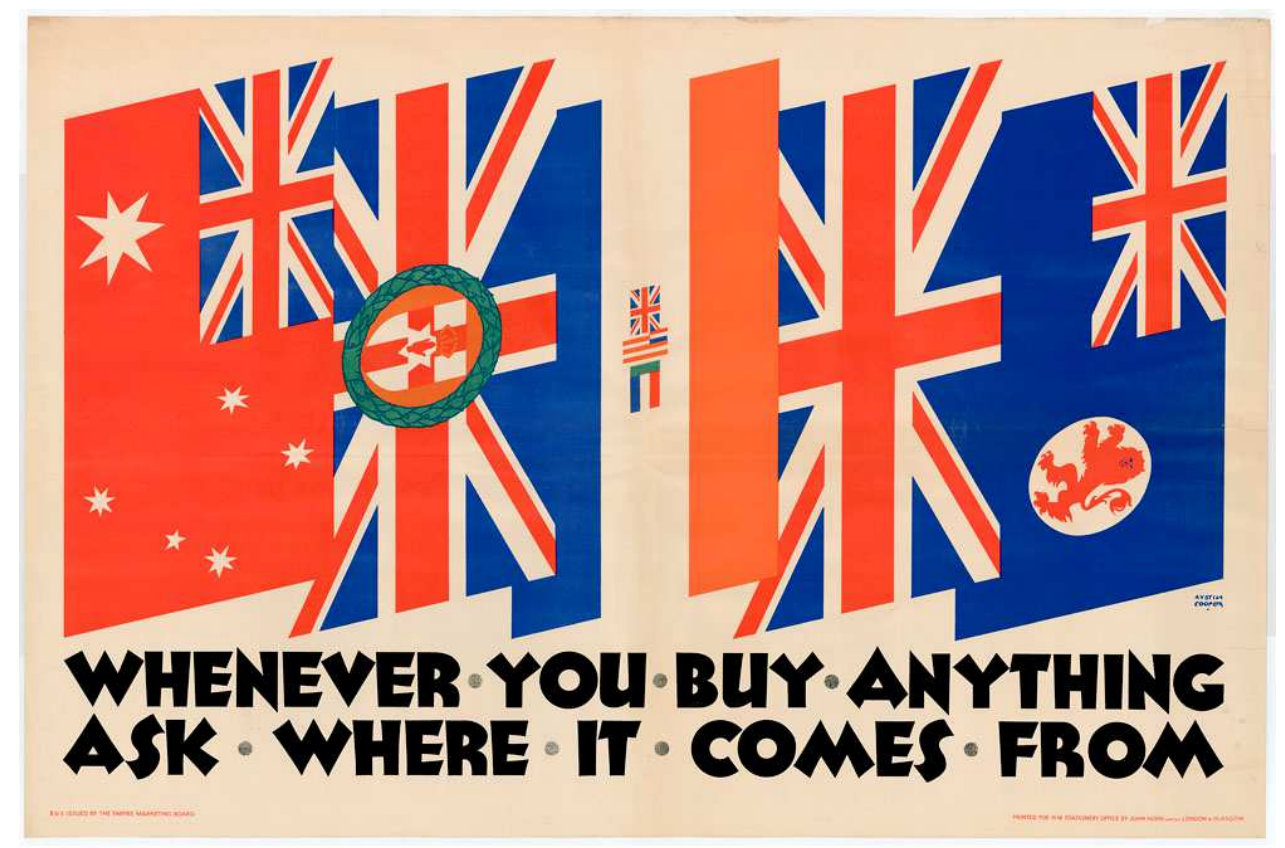

Library and Archives Canada / Bibliohneque et Archives Canada
www collectionscanadada.gc.ca

Figure 19. Austin Cooper. Whenever You Buy Anything Ask Where It Comes From. Lithograph. $151.1 \mathrm{x}$ $101 \mathrm{~cm}$. Library and Archives Canada. Ottawa, Ontario. MIKAN 2845313. http://www.baclac.gc.ca/eng/CollectionSearch/Pages/record.aspx?app=fonandcol\&IdNumber=2845313\&new=$\underline{8586297409452583532}$

\section{Buy British Campaign}

The "Buy British" campaign was another marketing attempt that, with the help of its publicity unit, sought to elicit help from farmers, manufacturers, and retailers to further encourage the purchase of Empire products. Launched in 1931, the Buy British campaign was a two week-long advertising effort that encouraged shoppers to buy home and Empire goods. Like the National Mark campaign, the Buy British campaign worked under the assumption that consumers preferred domestically and imperially-produced goods and that they should be further promoted. Over 1.5 million posters and window bills were printed and distributed "from the remotest village to the largest city," and were 
displayed on banks, theaters, public spaces, factories, and even aircraft ${ }^{313}$ (Figure 5). EMB advertising compelled producers and retailers to make British goods known to buyers. "British Producers!" one ad asserted," "Your part is clear. The British public wants British goods, of sterling British quality - goods from the Empire at home and overseas... By your packing, by your advertisement, by your displays in the shops make identification easy. Keep value up and prices down - and let the public know." ${ }^{314}$ Appeals were made to publicize British goods to encourage their purchase.

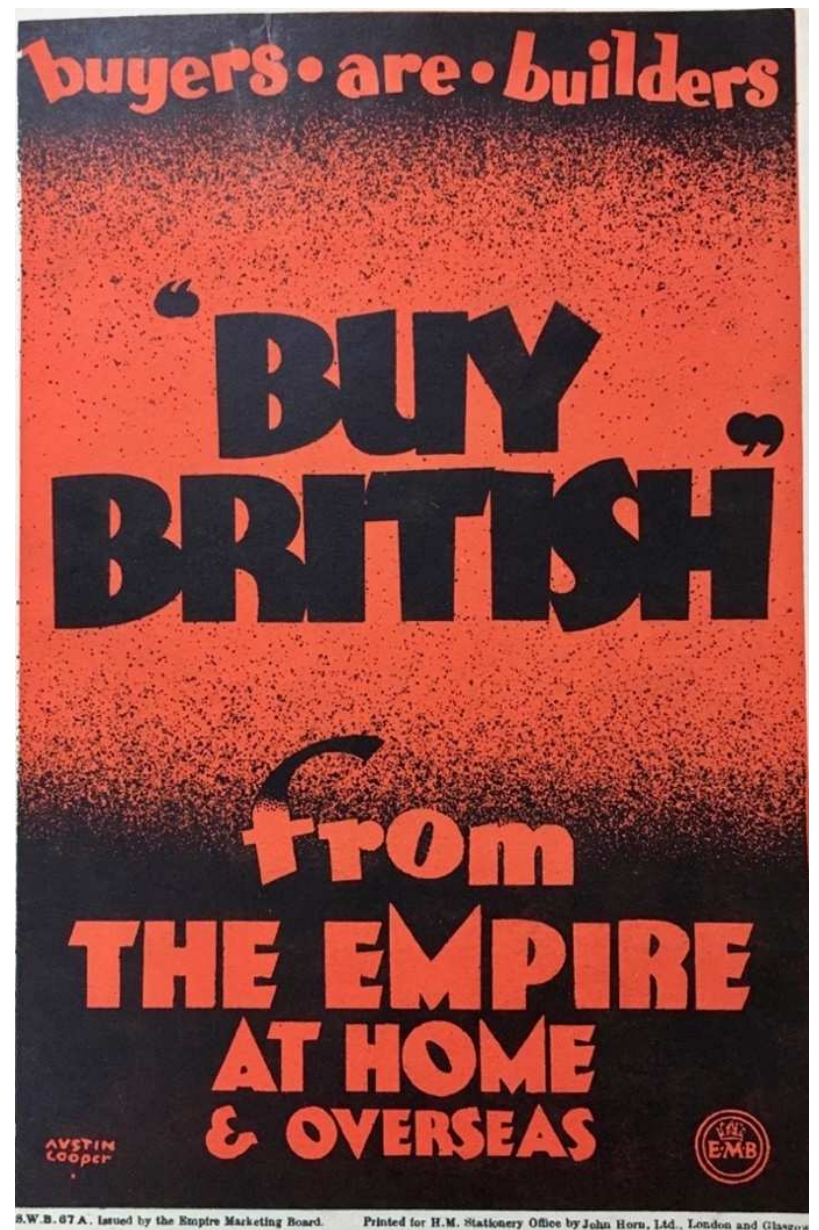

Figure 20. TNA CO 956/60

313 “Agricultural Bureau," Huron Times (Franklin, Tas.) February 19. 1932, 3. 314 The Times, November 16, 1931, 17. 
The need to aid domestic interests was especially marked in the early 1930s as unease about Britain's economic prospects loomed. Unemployment and the cost of social welfare measures were an ongoing concern. ${ }^{315}$ The Buy British campaign was encouraged to further help the balance of trade which, with the fall in exports, had reached crisis levels by 1931 and to sidestep political tensions over trade policy. ${ }^{316}$ The move to encourage national buying can also be read as a push to maintain national interests at a time of economic downturn. Though the "Buy British" message was, in theory, designed to include the entirely of the Empire, much of the emphasis went to stressing domestic troubles and how they could be overcome if shoppers sought out British goods. J.H. Thomas, then the Secretary of State for Dominion Affairs, noted a need to "convey to the mass of the people the national importance and the national necessity of the movement." He noted that, "no legislation of any kind that the Government could introduce could be so effective as the determination of the people themselves, when purchasing goods, to ask for British goods." ${ }^{317}$ Consumers thus conceived of as a vital resource for the improvement of the economy. Like the National Mark campaign, national concerns and imperial ones could be problematic as promoting one could contradict the other.

Another unintended consequence of the Buy British campaign were patriotic buying campaigns that began in tandem throughout the Empire. National buying

${ }^{315}$ Local Authorities and British Trade. Forms of Tender and the Empire Marketing Board: Public Assistance and Modern Taxation: Purchase in the Home Market as Relief for Unemployment. By the Editor. 22 April 1932. TNA CO 760/34

${ }^{316}$ Constantine, "The Buy British Campaign," 46.

317 "Buy British," The Times, November 14, 1931, 9. 
movements in Britain were also challenged by those of the Dominions, who also utilized their own national campaigns to sell goods. The Buy British campaign ran at the same time as the passing of the Statute of Westminster of 1931, which cemented the legislative independence of the Dominions. The issue of "British" was also complicated by populations in the Dominions, such as Afrikaners or French-speaking Québécois populations, that did not identify with being inherently British, making appeals to buy Empire products more ineffectual. ${ }^{318}$ Similar "Buy Indian" campaigns sought to bring attention to British-dominated trade networks and give a voice to Indian business interests. The swadeshi self-sufficiency movement in India proved to be a key component in India's independence from imperial rule. ${ }^{319}$ Stamps issued by the Federation of British Industries encouraging shoppers in London to "Buy British Made and Help British Trade" were challenged by stamps issued in India to "Boycott British Goods." 320 Appeals in India to "Boycott British" rather than "Buy British," worked in opposition to what the Board sought to propagate. The push to encourage patriotic buying among British consumers was not, then, only a British phenomenon, as the economic conditions of the period also encouraged national buying among other nations. This further undermined appeals to imperial unity and collectivity.

Beyond the rising tide of nationalist sentiment, other concerns presented themselves during the Buy British campign, which further illustrated the challenges that

318 David Thackeray, "Buying for Britain, China, or India? Patriotic Trade, Ethnicity, and Markets in the 1930's British Empire/Commonwealth," Journal of Global History 12, no. 3 (November 2017): 401.

319 Ibid., 390-91.

320 "'Buy British' Campaign." The Times, November 12, 1931, 16; HC Deb, July 20, 1931 vol. 255 cc 1046-7. 
were faced by the Marketing Committees. Through their contacts with the retail sector, the EMB also tried to gauge the effects of the Buy British campaign. The head of the Marketing Committee, Lachlan Maclean, solicited information from the retail sector to see how well products sold, especially the demand for goods and whether there was difficulty in meeting demand. In the months following the campaign, many retailers noted an increase in demand for empire goods. ${ }^{321}$ In London, one manager of the of the Earl's Court Branch of the Waitrose Grocery chain, Mr. A. Smith, noted an overall increase in demand generally but he also noted some difficulty selling Empire products like bacon because of the higher price point. Mrs. H. Page, Manager of the Finchley branch similarly observed that "people will be patriotic as far as their pockets will permit," that for consumers, "one thing animates them all, that is, price," revealing that the demand for products were still largely determined by the price of the goods rather than patriotic appeals. ${ }^{322}$ The manager of T. Walkton Fruit Merchants' Covent Garden location observed that consumption had increased among "the better classes," but "the greater percentage of our customers consider price first.." ${ }^{, 23}$ The observations of the retail sector, thus, illustrated that patriotic appeals could have an effect on sales, but price also proved a decisive factor in shoppers' abilities to buy Empire products.

Beyond price, there were other issues that presented themselves during the campaign. Some consumers simply refused to alter their preferences. The Managing

\footnotetext{
${ }^{321}$ Some Commercial Notes on the Result of the "Buy British Campaign," December 9, 1931, TNA CO 760/34

322 Managers Reports on "Buy British" campaign. 23 February 1932, 6. TNA CO $758 / 94 / 6$

${ }^{323}$ Letter from, TNA CO 758/94/6
} 
Director of a Waitrose grocery store noted that the more "fiery" South African brandy was "nothing like so mellow as French Brandy," and consumers failed to substitute the latter for the former in large numbers. ${ }^{324}$ Others similarly noted staples like canned fruit and bacon were not of sufficient quality compared to foreign products. ${ }^{325}$ In some cases, then, substituting new Empire products for other preferred products could prove unsuccessful with consumers.

Another problem was finding enough product. A memorandum circulated by the Marketing Committee noted that, with increased demand of some products, supplies could not be sustained in the long-term. It was recommended that retailers and producers be contacted to see if any openings might be available for larger supplies. In addition, the Food Products Committee recommended that any publicity attempts should be curtailed for products that were in short supply. ${ }^{326}$ One retailer from the Williams Brothers Direct Supply Stores noted difficulty in finding stocks of goods. He wrote in frustration that some promoted products could not, in actuality, be stocked and he asked for assurance of supplies in the future before advertising goods in the store, "otherwise it puts the retailer in a rather false position." ${ }^{\prime 327}$ Initial concerns raised by the Research Committee that it would be ineffectual to advertise products that couldn't be generated, at times, manifested

\footnotetext{
${ }^{324}$ Managing Director to Maj. Lachlan Maclean, 10 February 1932, 3. TNA CO 758/94/6 ${ }^{325}$ Managers Reports on "Buy British" campaign. 23 February 1932, 7. TNA CO $758 / 94 / 6$

${ }^{326}$ Minutes of the Fifteenth Meeting Held on Thursday, December 10th, 1931, at 4 o'clock p.m. in Committee Room No. 11 at the House of Commons; "Inadequacy of Supplies of Empire Produce. Preliminary Report by the Food Products Committee," January 22, 1932, TNA CO 760/34.

${ }^{327}$ Minutes of the Eighteenth Meeting Held on Thursday, 26th May 1932 at 4 p.m. in Committee Room 13 at the House of Commons, TNA CO 760/34.
} 
as a real concern while promoting Empire products as they did during the Buy British Campaign. For that reason, research to secure more products became even more important.

\section{$\underline{\text { Conclusion }}$}

Much of the behind-the-scenes work of the Marketing Committee involved canvassing, interviewing, and soliciting information from shipping companies, wholesalers, co-op members and retailers to learn more about products, consumers, how to facilitate the transfer of Empire products from one to the other. By providing producers and retailers with shipping information, wastage data, and consumer preference figures it was hoped that food could more efficiently move between the field or farm to the kitchen. In forging relationships with sellers, it was hoped that information garnered could help to promote the sale of new goods in the age of increased international competition. One of the EMB's goals at the outset, was to "make the Empire more efficient in competition with foreign countries," implying that it was not efficient at the time and, thus, required work to make it so. ${ }^{328}$ Unlike other exporting nations or private companies who had worked to oversee the entirety of production, and ensure quality, Empire products lacked standardization, consistent quality, and the ability to be supplied continuously. Thought the EMB tried to sell the idea of the Empire as an abundant Empire market, it was ultimately subject to the realities of geography, availability, and consumer preferences for foreign goods.

328 "Dominion Food Products," 7. 
The Board's array of marketing experts investigated how Empire products could be developed and substituted for foreign ones in the hopes of creating a superior Empire brand. The Marketing Committee sought to streamline and improve the production and promotion of goods, making them known to consumers. However, this was complicated by the fact that Empire products were not always made evident to shoppers as such. Uncertain product availability, additional cost, or inferiority compared to other foreign products similarly illustrated that creating an Empire brand that consumers would demand was a difficult, if not doubtful, task.

The EMB's attempts to market Empire goods was also challenged by national concerns, both at home and abroad. National Mark products were created to make domestic products known to consumers in order to build up their reputation for quality, as other national brands had done. National Mark products were created at the behest of British farmers who objected to the promotion of Empire goods over home-produced ones. The Buy British Campaign was similarly an attempt to build up national buying, which competed with imperial concerns as the premise of the EMB's initial mandate. This helps to further signal the hierarchical structure of Empire interests. Despite its cooperative rhetoric, the EMB's marketing works still illustrated that British interests continued to be given priority over those of the Empire.

The EMB's marketing aims sought to more fully rationalize the new imperial market by compiling information and resources, attempting to make complex economic forces predictable. Research and expertise were sought at home and throughout the Empire in order to more fully understand the complex inner workings of global forces. Such work was essential of Empire producers hoped to catch up foreign competitors. 
However, the EMB's abilities to shift such forces through marketing was likely limited as it faced a myriad of challenges and interests that were not always in agreement. The final link beyond those of producer and the retail sector was the consumer, and it was in the final area of its mandate - publicity - that the Board also turned in order to sell its products. The next chapter will look more in-depth at the Board's publicity aims and how the EMB tried to communicate directly with buyers. 


\section{Chapter Four}

Alternative Facts: Publicity, Propaganda, and the Creation of the Imperial Family

Stephen Tallents, Secretary of the EMB, noted that if Britain hoped to the keep up in the new world of modern media it had to "throw a fitting presentation of England upon the world's screen," portraying an image of imperial vigor and strength, even as the economic realities were more precarious. ${ }^{329}$ In addition to its scientific and marketing work, a large part of the EMB's operations were dedicated to publicity. The changing landscape of media during the 1920s altered the nature of publicity and the methods that could be used to reach the public. Rather than being limited to print, the new media that developed during the interwar period, such as the cinema and the radio, expanded the limits of advertising. It also gave government interests new tools to reach its citizenry, allowing propaganda to expand into new realms.

The visual materials utilized by the EMB sought to illustrate to consumers how they fit in to the imagined world of the "imperial family." The appeal to imperial patriotism and the duty of British shoppers to help the Empire was illustrated in many Board's promotional materials and events. Through posters, films, shopping weeks, ratio addresses, and educational materials the Board sought to appeal to shoppers directly, to encourage them reorient their buying toward the Empire by illustrating their place within a cooperative, Empire-wide unit. Taking advantage of newly-enfranchised groups, the EMB also sought to use such media to educate new political and consumer

329 Tallents, The Projection of England, 229. 
demographics of their place within the new system. The EMB projected a vision of Empire in which each part of the Empire could help the other in a mutual symbiosis.

However, the concepts and visualizations that the Board projected to consumers concealed underlying tensions. The vision of imperial cooperation that the EMB portrayed also hid underlying assumption about imperial roles and what function each part of the Empire would assume in the future. Hierarchies were embedded in the publicity work of the EMB just as it was for its scientific and marketing work. Its visual images sought to illustrate the Empire, its citizens, and their collective mission of securing the vitality of the Empire, but it was a projection that presupposed that Britain remained central and industrial while the rest of the Empire remained peripheral. Thus, examining the underling messages of its promotional material and events illustrates some of the larger tensions within the EMB's work as the EMB tried to make buyers into Empire shoppers.

\section{Publicity and The Rise of Consumer Culture}

The move to free trade and the expansion of the British Empire was also connected to the development of commercial advertising within Britain. The Victorian period saw the growth of cheaply-produced products and a growing commodity culture. Spectacles such as the Great Exhibition at the Crystal Palace had put products from all over the world on display for millions of visitors. In the 1880s, the advancement of print technology had helped to bring advertising to the masses, creating the first national 
consumer market. ${ }^{330}$ The increased flows of capital due to imperial expansion also led to the growth of the middle classes, with larger disposable incomes. ${ }^{331}$ Shopping became not just a utilitarian function but a social pastime. It had expanded the shopping experience into new realms, like department stores which appealed to increasing numbers of, especially, female shoppers. ${ }^{332}$ Corporate advertisers had recognized a need to capitalize on the emerging markets. Increased competition meant more elaborate marketing strategies to differentiate their products from others to appeal to consumers.

The use of media by the government had taken a new form and became an integral part of the efforts of the First World War. In 1914, the Foreign Office News Department, the Home Office Press Bureau, and the Neutral Press Committee were all created to disseminate and supervise the distribution of information. A secret office was established for the War Propaganda Bureau at Wellington House, where intellectuals and writers concentrated efforts on disseminating propaganda abroad. During the War, government departments such as the War Office, the Admiralty, and the Ministries of Munitions and Pensions, had also hired journalists for their staff to help disseminate information. ${ }^{333}$ The private sector was unofficially utilized as advertising executives such as Charles Hingham were asked to help produce materials to promote recruiting efforts and war bond sales, however no professionals formally

${ }^{330}$ Thomas Richards, The Commodity Culture of Victorian England (Stanford: Stanford University Press, 1991).

${ }^{331}$ Krista Lysack, Come Buy, Come Buy: Shopping and the Culture of Consumption in Victorian Women's Writing (Athens: Ohio University Press, 2008), 8

332 Ibid., 8.

${ }^{333}$ Mariel Grant, Propaganda and the Role of the State in Inter-War Britain (Oxford: Oxford University Press, 1994), 27-28. 
served in government departments during the War. ${ }^{334}$ Communications, propaganda, and public relations were briefly consolidated under the umbrella of the Ministry of Information in 1918, but was eventually terminated once the War was over.

By the post-war period, new innovations in mass media helped to change the landscape of advertising and gave the EMB new resources to utilize. The media was increasingly viewed as a useful tool to help reach the public, as both a political and economic influence. The British Broadcasting Company (BBC) was formed in 1922, bringing radio to increasing numbers of listeners. Film expanded from a relative novelty in the nineteenth century to a large mass medium in the 1920s. By 1925, Britain had 3,878 cinemas, which was further expanded with the introduction of "talkie" films, featuring sound, by $1929 .{ }^{335}$ The press had also expanded by the turn of the century as some the major paper such as the Daily Mirror, reach circulations of over a million; by 1912 there were 121 daily newspapers in circulation. ${ }^{336}$

Newspapers were seen as an important political asset, a way of reaching the masses - especially important within the context of the extension of the electorate in 1918. The period also saw the launch of political newspapers, such as the Daily Herald which gave a voice to the emerging Labour Party. Political parties began broadcasting on the radio by the 1924 elections and political printed materials were also utilized in earnest. Film also increasingly became a tool for fostering imperial, political, and

\footnotetext{
${ }^{334}$ Ibid., 28.

${ }^{335}$ Constantine, "Bringing the Empire Alive," 201. ${ }^{336}$ Ibid.
} 
economic solidarity. ${ }^{337}$ Cinema was conceived of as a powerful form of mass media that could reach the masses, especially the newly-enfranchised working classes. ${ }^{338}$

Conservatives began using cinema vans by 1925 , which traveled throughout Britain.

The vans projected films onto a rear screen and were used mainly among rural populations without access to cinemas. The Conservative Party would also produce their own political propaganda films prior to the EMB's formation.

New developments in graphic design after WWI also led to further advancements in advertising. By 1901, 77 percent of British people lived in towns with populations of over 20,000. ${ }^{339}$ Between 1922 and 1938, consumer expenditure grew in real terms by 38 percent, food and drink rose by 14 percent. ${ }^{340}$ Marketing schemes increasingly became directed toward larger, more diverse, and more concentrated populations. Advertisers, printers, and typographers made use of modern forms in innovative new forms of graphic design. The influence of American "jazz motifs" in advertising with geometric forms, bold type, and vivid color were evident alongside those that emphasized the more conventional "English" past and tradition. ${ }^{341}$ Buses, trams and trolleys - new technologies of transport - also became new instruments for advertising. Cheap, mass-produced posters became the medium for conveying concise

${ }^{337}$ Lee Grieveson, Cinema and the Wealth of Nations: Media, Capital, and the Liberal World System (Berkeley: University of California Press, 2017), 164.

${ }^{338}$ Ibid., 161

${ }^{339}$ Robert Fitzgerald, "Marketing Management in Britain: What is the Evidence for 'Failure?' in Business in Britain in the Twentieth Century ed. Richard Coopey and Peter Lyth (Oxford: Oxford University Press, 2009), 171.

${ }^{340}$ Ibid., 176.

${ }^{341}$ Cheryl Buckley, Designing Modern Britain (London: Reaktion, 2007), 48. 
messages to urban city-dwellers. The importance of the visual was an important part of modernity, with its emphasis on speed, technology and innovation.

Despite the advancement of the media, the use of publicity by the British government was relatively new, giving the EMB little precedent to go on. Walter Elliot would recall that "we [were] striking out into almost unknown territory...for the first time Government was to be not merely by consent, but actually by persuasion." ${ }^{342}$ The EMB envisioned a more large-scale marketing scheme than what had been previously utilized by the government during the War years. The Board turned to outside experts to advise on how to best utilize the new technologies and methods of the day to reach British shoppers and convey to them its message. The Board, thus, turned to the emerging advertising, public relations, and media specialists to help reach consumers and convince them about the virtues of buying from the Empire.

\section{The Publicity Committee}

The EMB's Publicity Committee was charged with finding ways to sell the concept of "Empire" to the masses. The Board appointed figures that had familiarity with non-governmental marketing, including Frank Pick, the Assistant Managing Director of the London Underground and William Crawford -- head of one of London's largest advertising firms. ${ }^{343}$ Frank Pick was chosen because he was considered a

\footnotetext{
${ }^{342}$ Walter Elliot, The Work of the Empire Marketing Board," Journal of the Royal Society of Arts LXXIX, no. 4101, (June 26, 1931): 738.

${ }^{343}$ The Undersecretary of State for the Colonies chaired the Publicity Committee and its members included the Comptroller-General of the Department of Overseas Trade, the Deputy Controller of the Stationary Office, and Director of the Imperial Institute. Other members of the Committee included outside resources such as the Chairman and Managing Director of Harrods Department Store, the Director of Education at the BBC, and the President of the Empire Press Union.
} 
visionary of brand design, helping to design the layout and commission modern art for the London Underground. He was described as "the nearest approach to Lorenzo the Magnificent that a modern democracy can achieve. ${ }^{" 344}$ His comparison to the great Medici art patron was reaffirmed by Gervas Huxley, another Committee member, would note that Pick's administrative acumen "was combined with a remarkable love and knowledge of the arts," and Huxley would note that it was Pick's experience that proved most helpful in promoting the Board's goals." ${ }^{345}$ Pick's previous experience in the private sector helped to more fully integrate advertising expertise within the sphere of government propaganda.

William Crawford, as one of the other figures with the most experience in advertising, played a central role in the EMB's publicity efforts. Crawford's' advertising agency, William Crawford Ltd., held contracts with many well-known clients such Chrysler, the American car company. The securing of substantial contracts allowed his firm to expand into the European market by the 1920s. Crawford also collaborated with governmental organizations, including the EMB, the Ministry of Housing, the General Post Office, and the Ministry of Agriculture. He consulted on issues of labeling - like those used in the National Mark campaign - issues of design, market strategies, and served as an important intermediary figure between government and the ad world. Crawford had an interested in German and Russian graphic design, which could challenge convention and 'break and disrupt consumers' traditional ways of seeing," as innovation was envisioned as an important way of reaching consumers

\footnotetext{
${ }^{344}$ Ernest Turner, The Shocking History of Advertising (New York: Dutton, 1953).

${ }^{345}$ Gervas Huxley, Both Hands, 127.
} 
and maintaining their interest. ${ }^{346}$ Crawford also saw advertising as a method of securing the Empire's stability. ${ }^{347}$

Tallents recognized the importance of using publicity as a tool to inform and persuade the masses. Tallents elaborated on his beliefs in a pamphlet entitled, The Projection of England, published in 1932. In it, he wrote,

To-day... another new world, less tangible but not less significant, is being rapidly disclosed. England has the need, the obligation, and the opportunity of establishing supremacy within in. That supremacy she can secure only by the exercise of a new and complicated art - national projection. ${ }^{348}$

According to Tallents, it was the mastery of "projection," what would become known as public relations, that would help Britain remain dominant on the world stage. For England to flourish in the "new world" as it had done in the old, Britain needed to promote itself and its abilities to the rest of the world. ${ }^{349}$ Tallents was aware of the need for image management and, thus, he recognized the need to sell Britain's positive image as a major power. Competitive advantage had become a creative process,

${ }^{346}$ Stefan Schwarzkopf, "Creativity, Capital, and Knowledge: The Crawford Agency and British Advertising in the Interwar Years," Journal of Cultural Economy 1, no. 2 (2008): 193

${ }^{347}$ Ibid., 185.

${ }^{348}$ Stephen Tallents, "The Projection of England," (1932) in Scott Anthony, Public Relations and the Making of Modern Britain: Stephen Tallents and the Birth of a Progressive Media Profession (Manchester: Manchester University Press, 2011), 209. ${ }^{349}$ Somewhat paradoxically, Tallents sought a 'new order' by projecting concepts of traditional England. His recommendations for institutions that should be the foci included symbols such as the monarchy and Parliament, the Navy, traditional authors such as Shakespeare and Dickens, Oxford and St. Andrews University, major London landmarks such as Big Ben, Piccadilly, and Bond Street, The Times, the English countryside, and sport such as football, foxhunting, and Wimbledon, as well as its national and international reputation of "justice law, and order." See Tallents in Anthony, 211-12. 
facilitated by a host of new media. Power would be projected not through military might, but psychological and emotional influence.

\section{Propaganda Posters}

As has been demonstrated, a large part of the Publicity Committee's work included the commissioning of propaganda posters, of which there were more than 800 designs. ${ }^{350}$ The poster campaigns cost all together $£ 426,879$ and were the largest part of the EMB's publicity budget. ${ }^{351}$ Graphic artists as such as Charles Pears, Clive Gardiner, E. McKnight Kauffer, and F.C. Harrison were commissioned to produce works for the Board. The first posters were commissioned for existing commercial structures. The EMB also became noted for their poster sets, typically a five- poster sequence promoting a common theme, decorated with ornate wooden frames. Crawford and Pick thought that having posters of high aesthetic quality would encourage their message most effectively, with framed posters being more arresting and tasteful. By 1933, posters had been put up at 1,800 sites in 450 towns and cities. ${ }^{352}$ Other smaller materials in the form leaflets and pamphlets were also distributed. Posters were also sent to schools, post offices, and theatres. The EMB's efforts were also seen at local exhibitions throughout the year and many local retailers responded to the Board's encouragement and staged their own Empire Shopping Weeks using the Board's visual imagery. ${ }^{353}$

350 Stephen Constantine, Buy \& Build: The Advertising Posters of the Empire Marketing Board (London: H.M.S.O, 1986), 1.

${ }^{351}$ Ibid.

352 Constantine, "Bringing the Empire Alive," 211.

353 Anthony, Public Relations and the Making of Modern Britain, 30. 
Several themes emerge in the EMB's appeals to consumers as it sought to educate and encourage them about the role that they might play in the new imperial project. One common theme in the Board's propaganda were the commodities of Dominion and colonial nations. Frank Newbould's Mutton, Lamb, Apples, (Fig. 21) part of the "Buy New Zealand Produce" collection from 1931, illustrates Dominion commodities ripe for purchase by British consumers. Colonial products were also advertised, including things such as Gold Coast cocoa, as seen in McKnight Kauffer's poster Cocoa (Fig. 22) and Burmese lumber, evident in Ba Nyan's Timber Stacking (Fig. 23) ${ }^{354}$ Many other colonial commodities were advertised as well. These included everything from Malayan pineapples to Jaffa oranges to Nyasaland tobacco - all products that could be extracted from the Empire rather than foreign sources.

\footnotetext{
${ }^{354}$ Felicity Barnes argues that there was distinct differentiation between the ways in which the Dominions, semi-autonomous nations within the Empire, were represented through EMB propaganda versus those of the colonies. Contrary to the portrayal of the Empire as a family unit, she notes a "Dominion discourse" at work in which hinterlands appear more "British" to differentiate them from the colonies, and thus reaffirm a social hierarchy. She also notes that the Dominions themselves were actively involved in that representation. See Barnes, "Bringing Another Empire Alive? The Empire Marketing Board and the Construction of Dominion Identity, 1926- 33," The Journal of Imperial and Commonwealth History 42, no. 1 (2014): 64 .
} 


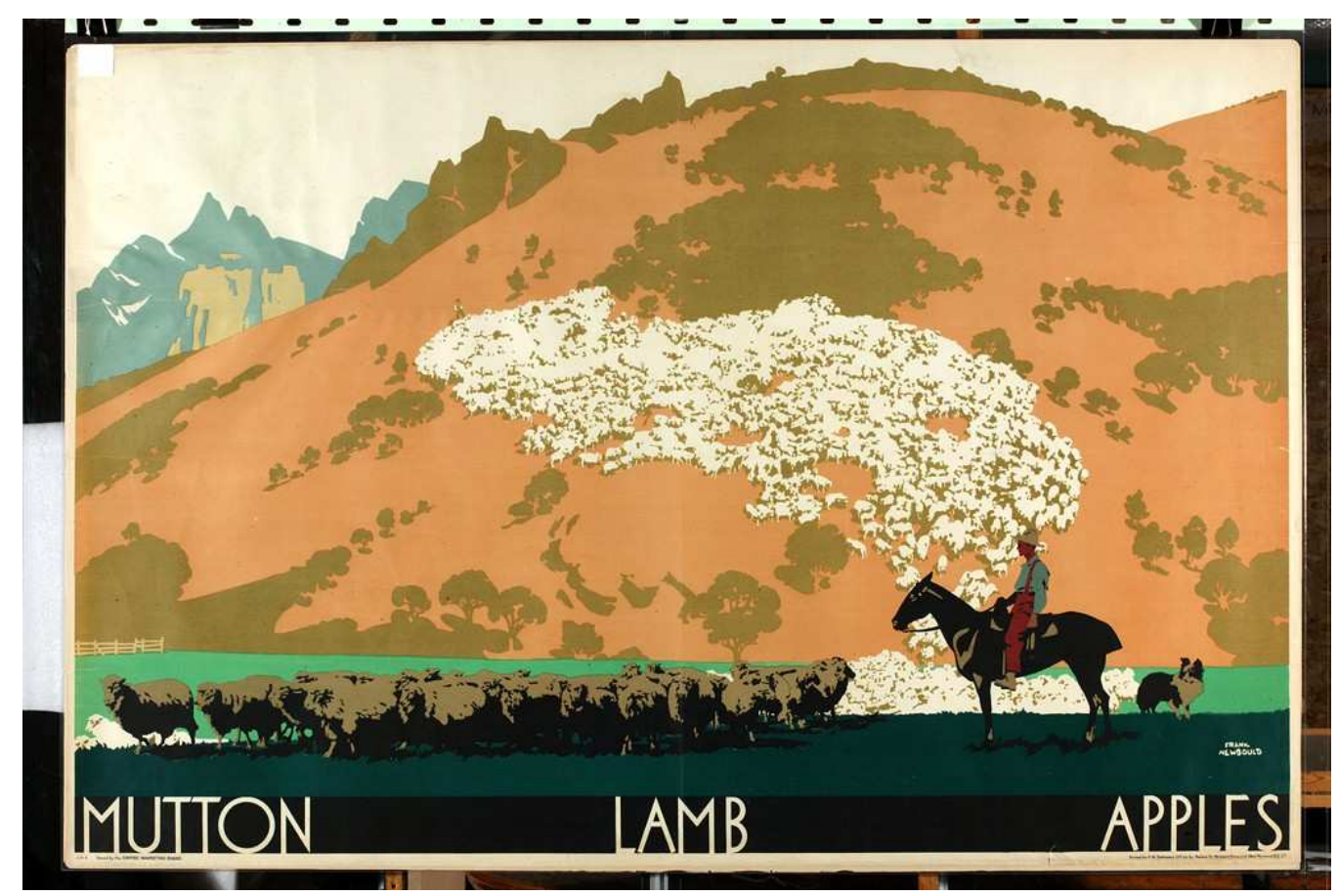

Figure 21. Frank Newbould, Mutton, Lamb, Apples, Top Caption: Buy New Zealand Produce. 1932. Manchester Art Gallery, Manchester, England.

https://www.flickr.com/photos/manchester city galleries/6811306537/in/album-72157629154862059/

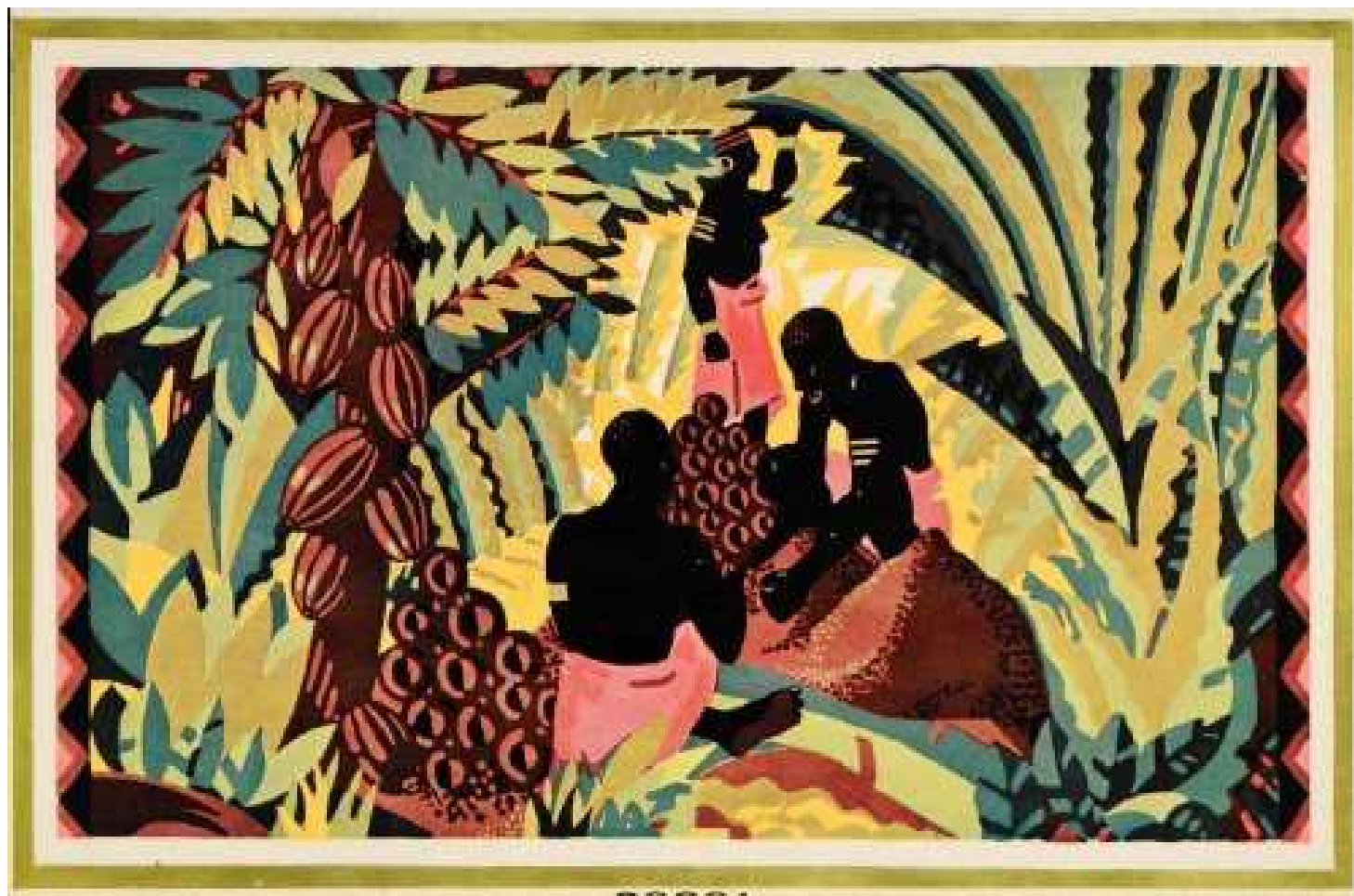

Figure 22. E. McKnight Kauffer, Cocoa, 1928. Lithograph. 151.5x101.2 cm. Library and Archives Canada. Ottawa, Ontario. MIKAN 2845245. http://www.bac-

lac.gc.ca/eng/CollectionSearch/Pages/record.aspx?app=FonAndCol\&IdNumber=2845245 


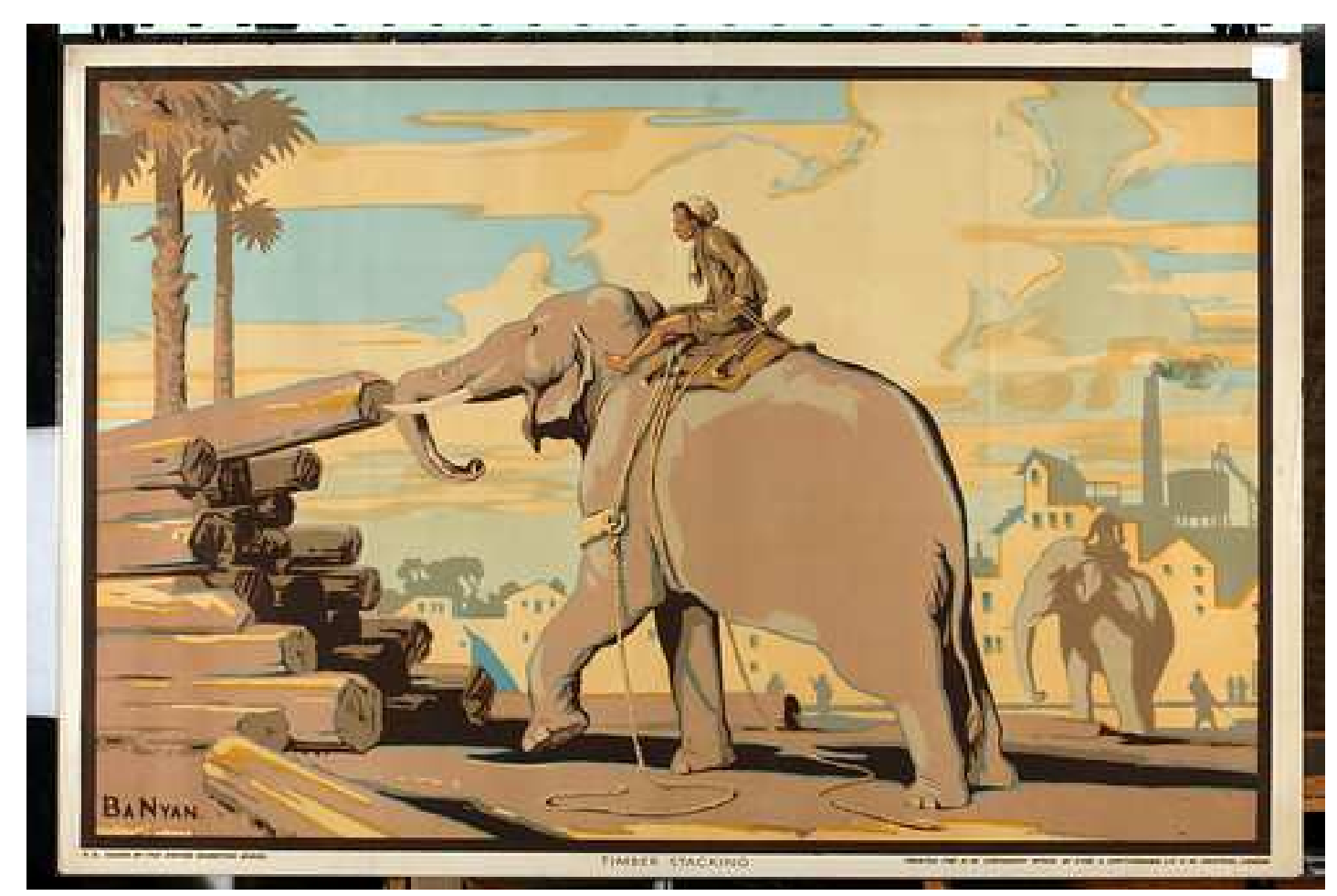

Figure 23. Ba Nyan, Timber Stacking, Top Caption: Burma, A Land of Rich Resources, 1928. Lithograph, $51 \times 75 \mathrm{~cm}$. Manchester Art Gallery, Manchester, England.

https://www.flickr.com/photos/manchester_city_galleries/6812151429/in/album-72157629157311483/

Another of the poster's themes included not just renderings the commodities of

Empire but advertising profiles of producing countries. Works likes those of Charles

Pears and John Waddington (Fig. 24) illustrate the use of statistics and information

alongside visual imagery to educate the public on trade relations with other parts of the

Empire. Amery had observed that the British public could be unfamiliar with the

countries that made up the Empire. Consumer ignorance was an issue that had to be

addressed if shoppers were going to be compelled to buy Empire products. Thus, many

of the EMB's posters were produced with information about the Empire, including

production or trade statistics. Here, Pears and Waddington's poster illustrates that

Australia was a major supplier of British butter and, in turn, Australia purchased British 
manufactured goods. It helped to illustrate to British consumers that buying from the Empire strengthened domestic industry because it allowed consumers in the Empire to buy British products. ${ }^{355}$ The quid-pro-quo relationship between Britain and the Empire illustrated both the characteristics of imperial products and how it helped domestic and Empire industries when consumers purchased them.

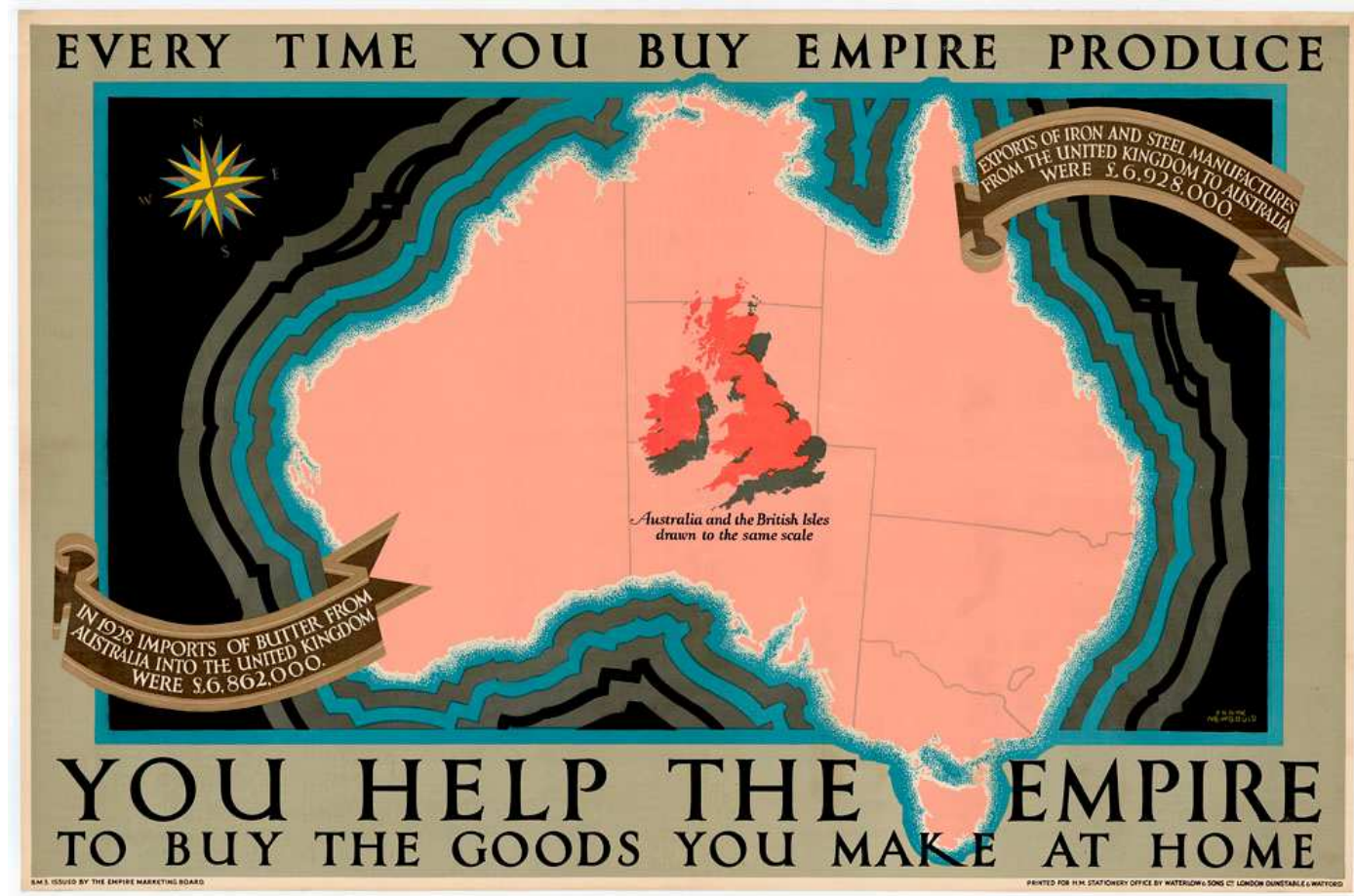

Library and Archives Canada / Bibliothèque et Archives Canada
www.collectionscanada.gc.ca

Figure 24. Empire Marketing Board. Every Time You Buy Empire Produce You Help the Empire to Buy the Good You Make at Home. Lithograph. 151.1 x $101.1 \mathrm{~cm}$. Library and Archives Canada. Ottawa, Ontario. MIKAN 2845088. http://www.bac-

lac.gc.ca/eng/collectionsearch/Pages/collectionsearch.aspx?DataSource=Images\&q=empire+marketing + bo ard\&start $=50 \&$ num $=50 \# 1-24$

${ }^{355}$ Jonathan Allen Moore, "Selling Empire: A Historical Perspective on Selling Foreign Products in Domestic Markets," Journal of Historical Research in Marketing 8, no. 2 (2015): 271. 
Visually, the commodities of the Empire were also connected to themes of technology and development. Ideas about progress and modernity were central motifs in EMB posters. Charles Pears' Suez Canal (Fig. 25) juxtaposes the transportation methods of the old world and the new, seen in the Egyptian figures and pack-carrying camels, contrasted with the modern innovations of British shipbuilding. Similarly, Clive Gardiner's Motor Manufacturing (Fig. 26), with its assertion that "Empire Buying Makes Busy Factories," illustrated that it was British manufacturing power that would help to process the world's commodities and encourage international development. In the EMB's portrayal, the Empire was made up of producers of raw materials, while it was Britain that would be placed in charge of processing goods. The belief in the cultural and economic superiority of Britain was a subtext of the messages of progress, reaffirming the social hierarchy between Britain and its Empire. The emphasis on Britain's humanitarian role, helping other nations achieve a greater level of development, hid the economic realities under which such a system was based. ${ }^{356}$

${ }^{356}$ Uma Kothari, "Trade, Consumption and Development Alliances: The Historical Legacy of the Empire Marketing Board Poster Campaign" Third World Quarterly 35, no. 1 (2014): 53. 


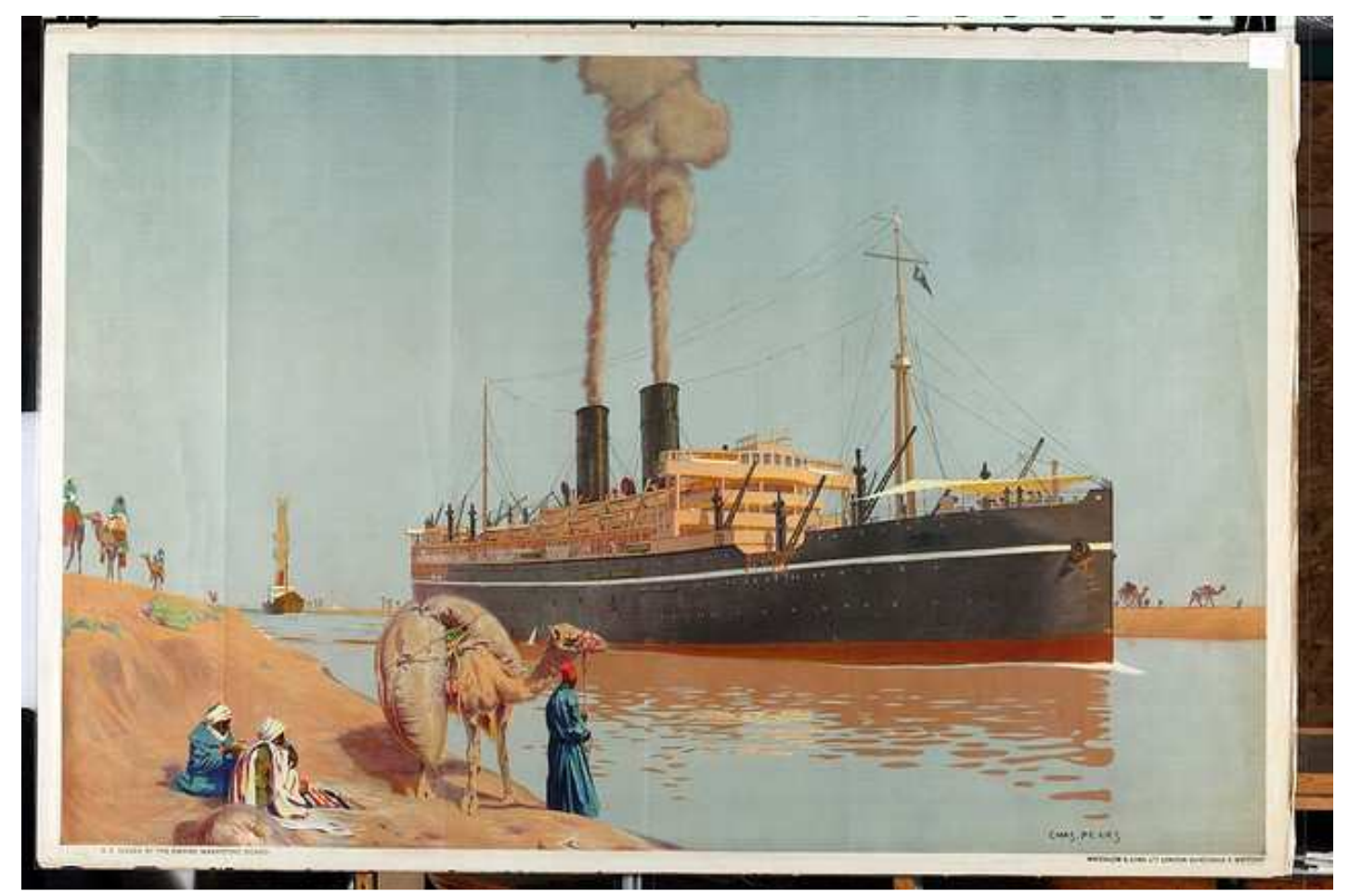

Fig 25. Charles Pears, Suez Canal, 1927. Lithograph, 102 x 152.5 cm. Manchester Art Gallery, Manchester, England. https://www.flickr.com/photos/manchester_city_galleries/6811517219/in/album$\underline{72157629155501571 /}$

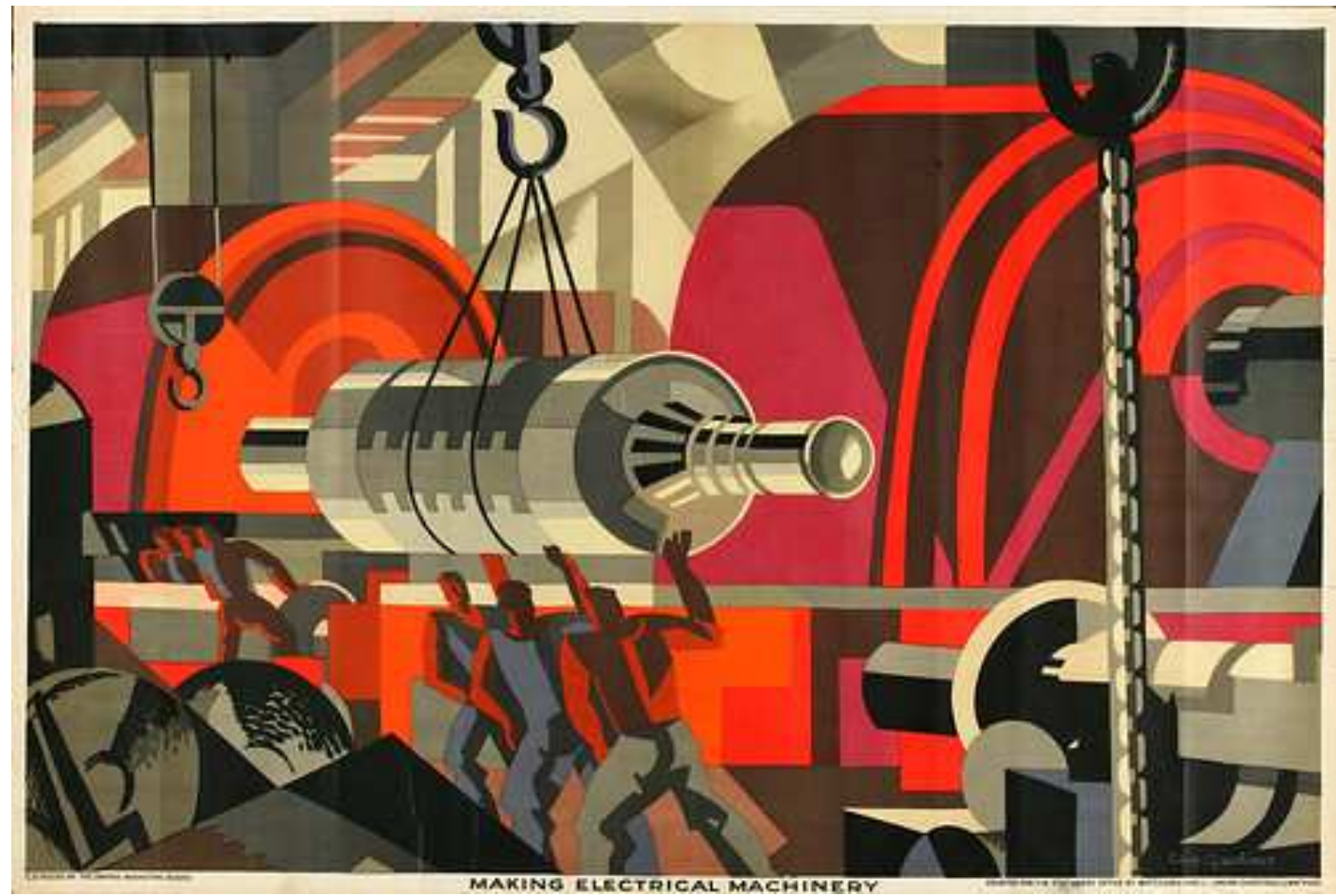

Figure 26. Clive Gardiner, Making Electrical Machinery, Top Caption: Empire Buying Makes Busy

Factories. 1928. Lithograph. 102 x $152.5 \mathrm{~cm}$. Manchester Art Gallery. Manchester, England.

https://www.flickr.com/photos/manchester_city_galleries/6811387983/in/album-72157629155091561/ 
A similar manifestation of that theme was illustrated more directly through poster motifs that concentrated on a single commodity and how it linked suppliers, manufacturers and, by extension, consumers. The goal of influencing consumers was also tied to the idea of making them conscious of their place within the new cooperative Empire. Uma Kothari notes that the EMB "bridged the farthest spatial, economic and emotional distances of the global food system at the time." ${ }^{\prime 357}$ Thus, posters illustrating "picking Empire grown tea" and "drinking Empire grown tea" (Fig. 27) visually link the production of goods with their consumption at home. The EMB used posters to portray a reimaging of imperial relationships, illustrating how the consumption of goods benefited producers in their place of origin. In order for consumers to shift their purchasing behavior toward Empire products, The EMB encouraged shoppers to think in terms of imperial altruism, envisioning how their purchases could benefit producers at home and throughout the world.

${ }^{357}$ Kothari, "Trade, Consumption and Development Alliances," 47. 


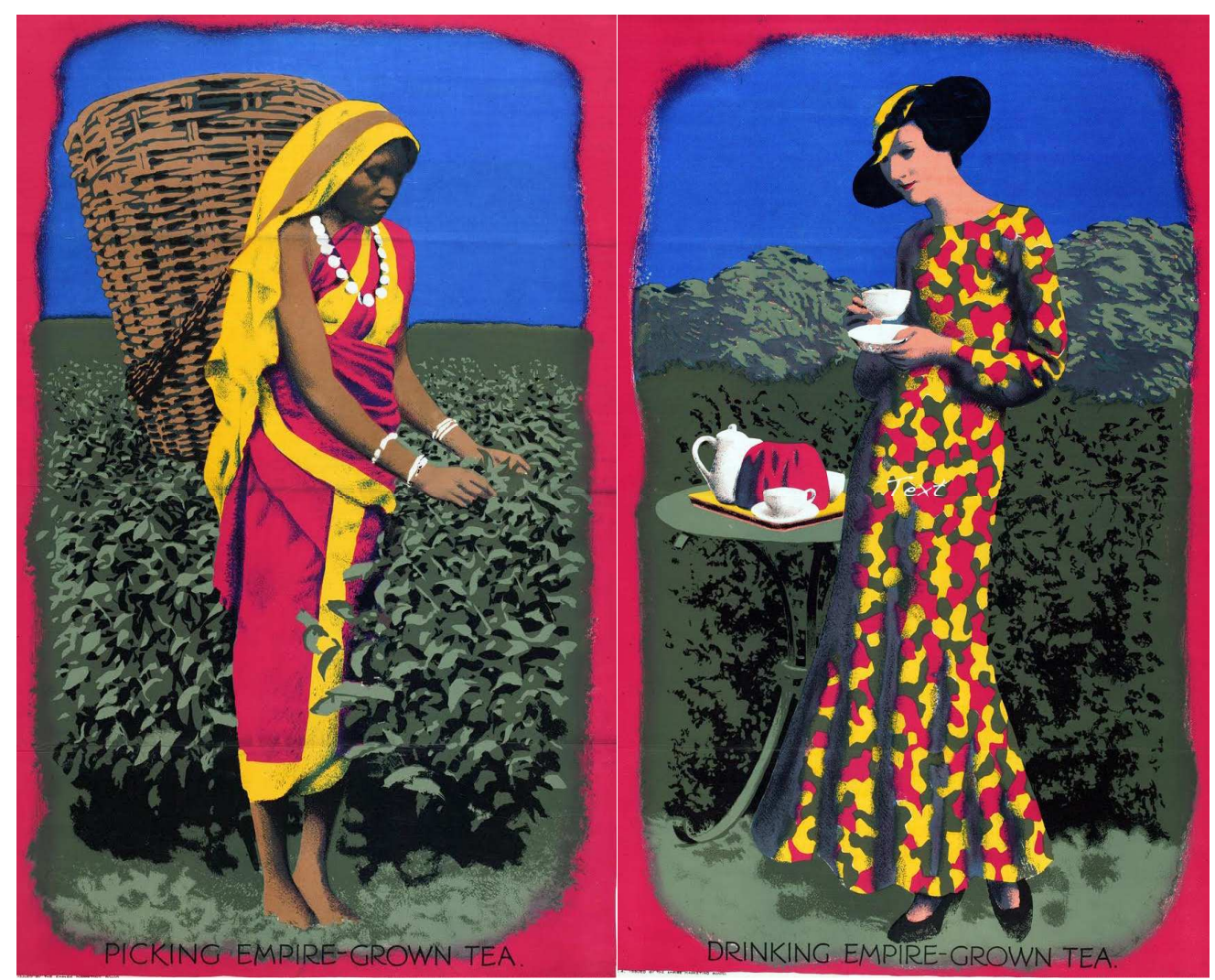

Fig. 27. H.S. Williamson. Drink Empire Grown Tea series, 1931. Lithograph. 102 x 64 cm. Manchester Art Gallery. Manchester, England.

https://www.flickr.com/photos/manchester_city_galleries/sets/72157629155541401/

The portrayal of the tea growers also concealed the true origins of their production, which were often more coercive than the EMB would lead consumers to believe. Tea interests, such as the Indian Tea Association served as a lobby for the industry. It collaborated with the EMB to help it in its marketing work. ${ }^{358}$ The growth of Indian tea-producing regions such as Assam meant increased demand for workers, rising from 107,847 tea pickers in 1885 to 247,760 in $1900 .{ }^{359}$ However, low wages,

\footnotetext{
358 "Empire Marketing Board. Marketing Committee. Food Products Committee. Minutes of the Fourteenth Meeting Held in Wednesday May 6thm 1931 at 2:15pm in the Board's Conference Room, TNA CO 760/11

${ }^{359}$ Rana Behal, "Forms of Labour Protest in Assam Valley Tea Plantations, 1900-1930," Economic and Political Weekly 20, no. 4 (Jan. 26, 1984): 19. 
maltreatment, and strict control of movement had led to rising instances of desertion, riots, and strikes among the workers in the early $1920 \mathrm{~s} .{ }^{360}$ The ITA's ties to colonial authorities allowed it to continue coercive labor practices on the plantations, and it successfully lobbied the Assam government to provide law enforcement to suppress workers strikes. ${ }^{361}$ Similar systems of coercion were evident in producing countries such as Ceylon, where tea producers like Lipton sought to oversee the entirety of production and marketing, "direct from the Tea Garden to the teapot."362 Like the EMB's advertising, Lipton sought to portray bucolic visions of female planters, which hid the debt peonage systems under which Tamils from South India were often recruited to work on Ceylonese plantations. ${ }^{363}$ The hilly terrain of the plantations also allowed for the control of mobility and separation from outside political influences. ${ }^{364}$ The conditions under which workers were subjected were often concealed in the representations of worker's lives portrayed in the EMB's advertisements. Such systems and were not just unique to one region or one commodity but were replicated throughout the Empire.

Similar assertions about how workers would fit into the new cooperative system were evident through the depiction of British workers. Posters also sought to project how workers at home could further the imperial cause. It was also an attempt to

\footnotetext{
360 Ibid., 19-20.

${ }^{361}$ Rana P. Behal, "Power Structure, Discipline, and Labour in Assam Tea Plantations Under Colonial Rule,” IRSH 51 (2006): 145-46.

${ }^{362}$ Edward D. Melillo, "Empire in a Cup: Imagining Colonial Geographies Through British Tea Consumption," in Eco-Cultural Networks and the British Empire: New Views on Environmental History, ed. James Beattie, Edward Melillo, and Emily Gorman (London: Bloomsbury, 2015), 76.

363 Ibid., 73-74.

${ }^{364}$ Ibid.
} 
incorporate the new electoral demographic into the imperial fold. The Representation of the People Act of 1918 had given all men over 21 the right to vote, regardless of whether or not they owned property. In a sequence of posters by Fred Taylor, outer panel posters illustrate several accomplished men in English history from James Cook to David Livingstone to Cecil Rhodes. On the interior panel, however, dockworkers are shown (Fig. 28). These were portrayed as the new "Empire Builders." The belief that “Every Empire Worker an Empire Builder," reflected the notion that all laborers could contribute to the prosperity of the Commonwealth. If Britain was to assert industrial dominance it would need the help of industrial workers. The same builders could be seen in the sugar farmers of Mauritius, or the cotton growers of Sudan. In the EMB's vision, all workers could come together for the benefit of the Empire. Accordingly, it was the job of the viewer to support the mutually advantageous trade system and increase Empire purchasing power.

But depictions of British workers also caused at least some outcry. Grierson noted that during the Buy British Campaign, when posters of workers were put up to reaffirm "the working man as national symbol," he was surprised to "hear from half a hundred Blimps that we were 'going Bolshevik." ${ }^{365}$ Anxiety about the representation of workers also signaled unease about working class discord, especially within the context of economic decline and the recent memory of the 1926 General Strike. Discordant politics and labor issues signaled troubled times for Britain. The EMB assertion, "Every Empire

${ }^{365}$ Grierson, On Documentary, 206. 
Worker an Empire Builder," can thus also be read as an attempt to unite interests that were in tension, further signaling internal discord.

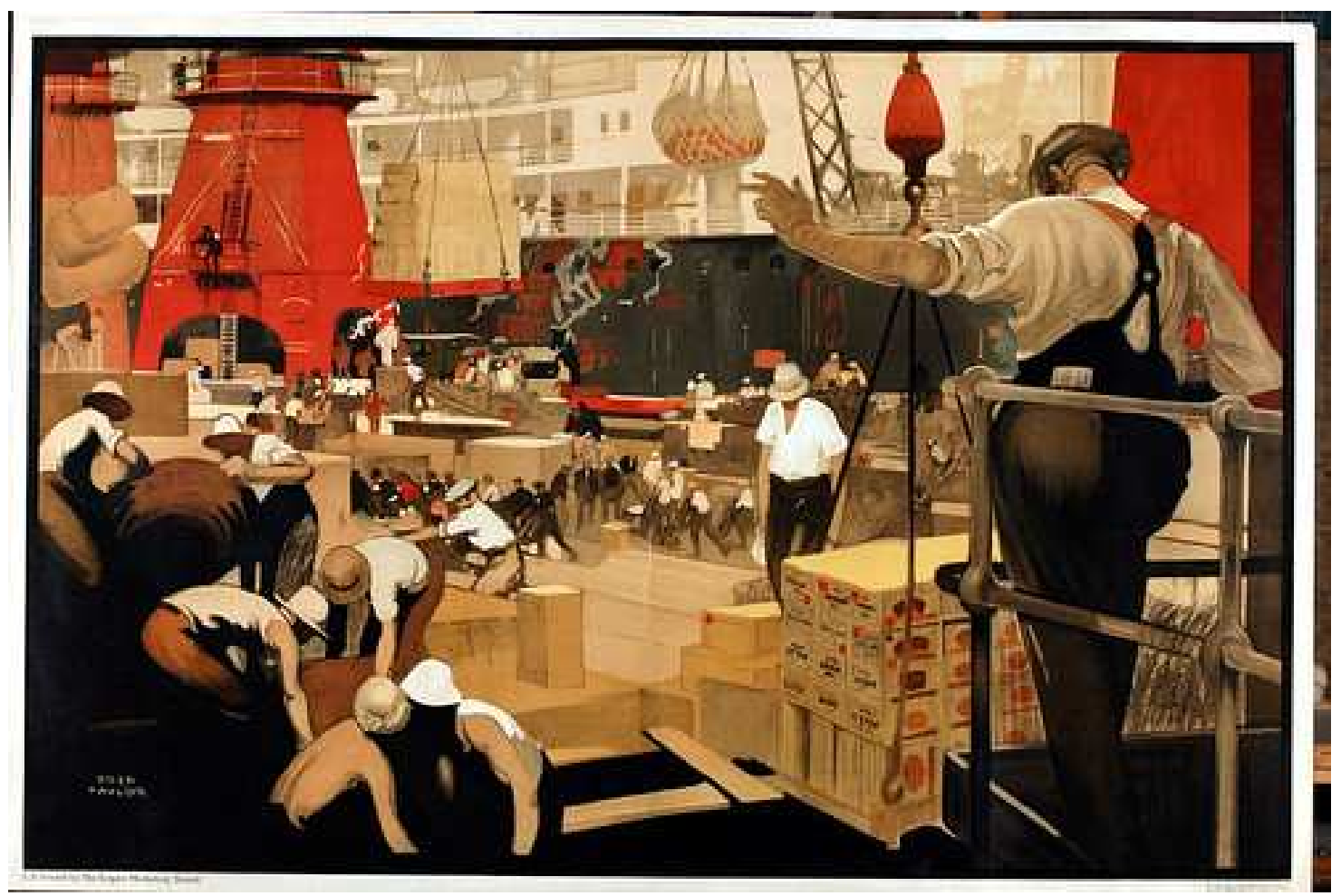

Figure 28. Fred Taylor, The Empire is Still in Building. 1927. Lithograph. 102 x 152.5 cm. Manchester Art Gallery, Manchester England.

https://www.flickr.com/photos/manchester_city_galleries/6812077997/in/album-72157629157114255/

If workers were to be a focus of imperial consumption efforts, so too were women as the principal shoppers. Persuading female consumers to buy imperially was another focus of the EMB's poster campaign. In one of the Board's published pamphlets it would assert that, "Empire shopping is...not merely a question of sentiment. Every woman who buys Empire produce may be sure that she is definitely helping an Empire country to develop and prosper," including her own country, as 
development would also mean jobs for workers at home. ${ }^{366}$ The image of women shopping, surrounded by presumably Empire goods signaled her role in the Empire through her shopping habits (Fig. 29). It illustrated that in buying products from the Empire for her actual family, women would be able to help their larger imperial family. The need to create "a more humanitarian imperial project" meant the need to portray the Empire as an interconnected family, and women were seen as the benevolent unifiers. ${ }^{367}$ However, the projection of women as housewives also obscured the changing roles for women in the 1920s, especially after 1928 when all women in Britain attained the right to vote. Women increasingly entered into positions in the workforce that had traditionally been open only to men. The vision that the EMB projected of women as imperial shoppers was, then, somewhat limited and obscured the changing cultural landscape of the interwar period.

${ }^{366}$ B.B.C. Household Talks (London: BBC, 1929), introduction.

${ }^{367}$ Kothari, "Trade, Consumption and Development Alliances," 56. 


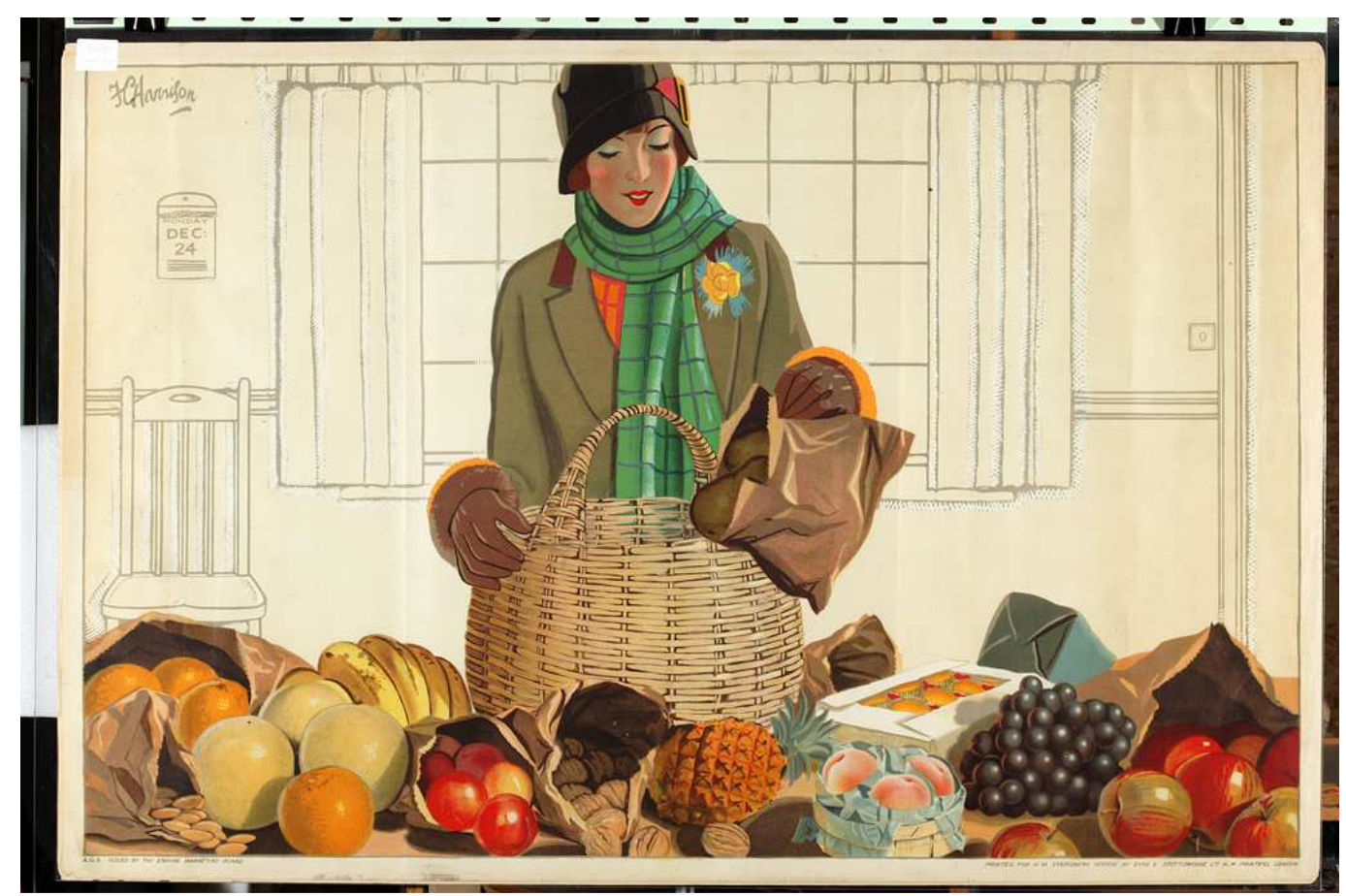

Figure 29. F.C. Harrison, Christmas Fare from the Empire series. 1928. Lithograph. 102 x $152.5 \mathrm{~cm}$. Manchester Art Gallery. Manchester, England.

https://www.flickr.com/photos/manchester_city_galleries/6811430079/in/album-72157629155216945/

The international vision of the unified Empire was also noted in works such as Harold Sandys Williamson's sequence, John Bull, Sons and Daughters (Fig. 30). The EMB capitalized on the familiar trope of John Bull, who evolved as the personification of England in the $17^{\text {th }}$ century and became especially prominent after the turn of the century advertising boom alongside other symbols such as Britannia and the British lion. ${ }^{368}$ Williamsons' work depicts the Empire as a plentiful store, whereby shoppers could take their pick of products. Its caption, "The Empire is Your

\footnotetext{
${ }^{368}$ Erika Rappaport illustrates that using patriotic Empire imagery to sell goods was not a new phenomenon. Many businesses capitalized on familiar British symbols to advertise their goods. See Erika Rappaport "Art, Commerce, or Empire? The Rebuilding of Regent Street, 1880-1927," History Workshop Journal 53 (Spring 2002): 94-117; Robert Opie, Rule Britannia: Trading on the British Image (Middlesex: Penguin, 1985), 12-13.
} 
Garden," denoted that shoppers could buy products from all over the Empire.

Products included Canadian cheese, Ceylonese tea, Kenyan coffee, Indian spices, and Irish Free State eggs. ${ }^{369}$ The message given was that territories of the Empire were part of the imperial "family," thus purchasing from one's "sisters and brothers" would benefit the entire imperial clan. The EMB utilized similar rhetoric in other proclamations such as "The Empire is One Large Family," "Keep Trade in the Family," and "Remember the Empire, Filled with Your Cousins," which all sought to reconfigure perceptions of the Empire into more acceptable terms by ending the association of Empire with exploitation. ${ }^{370}$

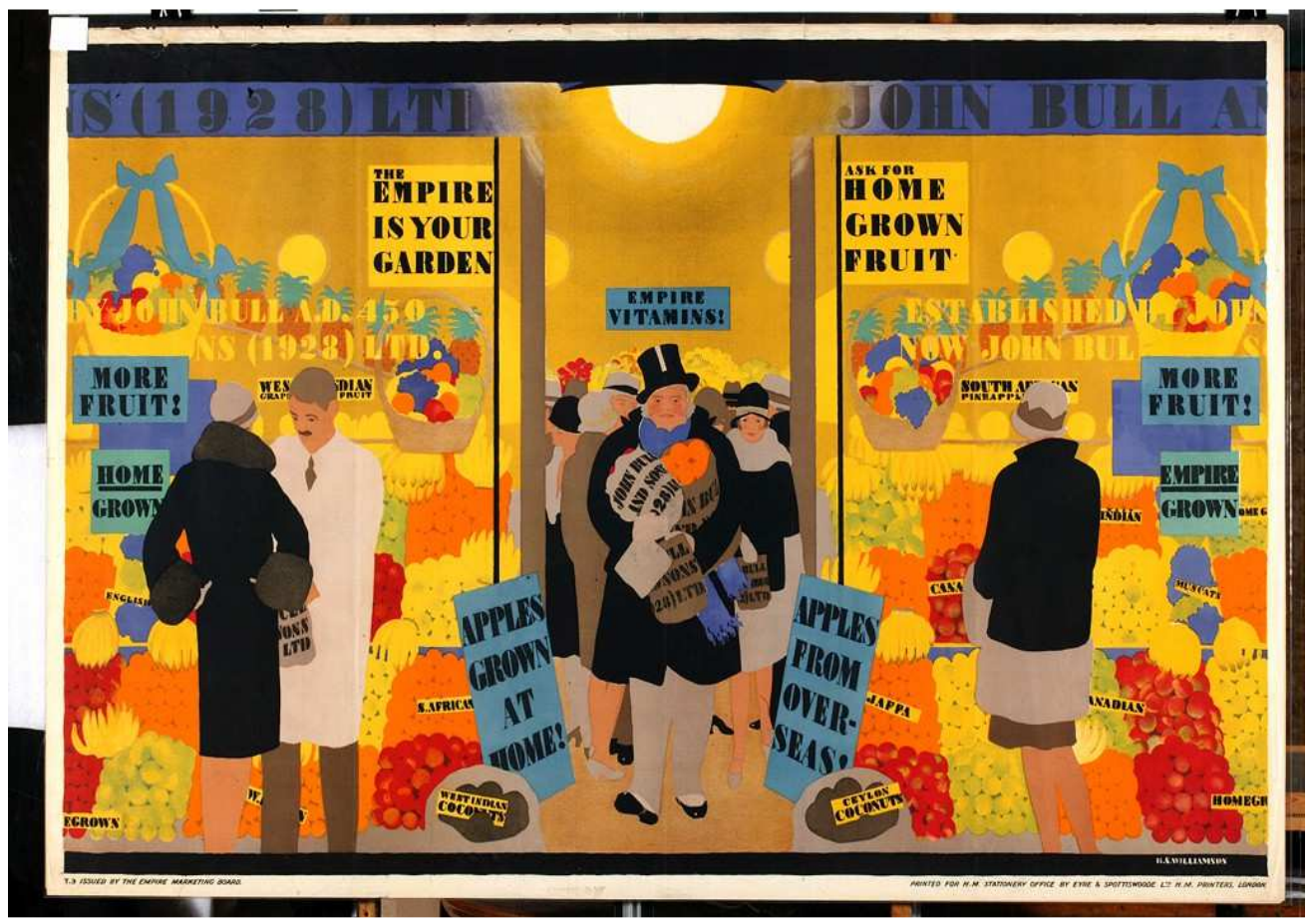

Figure 30. H.S. Williamson, John Bull, Sons and Daughters, 1928. Lithograph, 102 x $152.5 \mathrm{~cm}$. Manchester Art Gallery, Manchester, England. https://www.flickr.com/photos/manchester_city_galleries/6811423797/in/album$\underline{72157629155193971 /}$

${ }^{369}$ Lydia Foy. The Art of Persuasion: Posters of the Empire Marketing Board 1926-1933. (Ottawa: National Archives of Canada, 1990).

${ }^{370}$ Constantine, "Bringing the Empire Alive," 217. 
Another popular symbolic reference that was used was the Empire Christmas pudding, one that would be capitalized on later in cinema as well. Christmas pudding had been a cultural staple in Britain since the Middle Ages. In 1924, the Women's Unionist Organization had urged families to "make your Christmas pudding this year an Empire pudding," and had provided a recipe listing ingredients from throughout the Empire. ${ }^{371}$ By 1926, The Times was reporting in the EMB's publicity campaigns that, "the Empire is self-sufficient for all manner of Christmas fare." 372 This tradition continued into 1927 with an official pudding recipe composed by the royal chef, André Cédard. ${ }^{373}$ The printed version by F.C. Harrison illustrates a recipe made up entirely of Empire commodities (Fig. 31) including things such as Australian currents, candied peel from South Africa, British Guiana sugar, Indian cinnamon, Zanzibar cloves, Jamaican rum, along with British breadcrumbs, beef suet, and beer. In addition to encouraging Empire trade, the cultural expropriation of the pudding helped to extend the concept of "Britishness." The goal was to sell both British goods and British culture, while furthering the concept of Empire unity. ${ }^{374}$ The recipe, through the amalgamation of ingredients, symbolically represented the Empire as a single unit, further emphasizing the new version of Empire that the EMB attempted to propagate.

371 "Empire Christmas Puddings." The Times, December 5, 1924, 12.

372 "Christmas Food from the Empire," The Times, December 24, 1926, 7

373 "Display Advertising." The Times, November 11, 1927, 11.

${ }^{374}$ Kaori O' Conner, “The King's Christmas Pudding: Globalization, Recipes, and the Commodities of Empire." Journal of Global History 4, no. 1 (March, 2009): 134. 


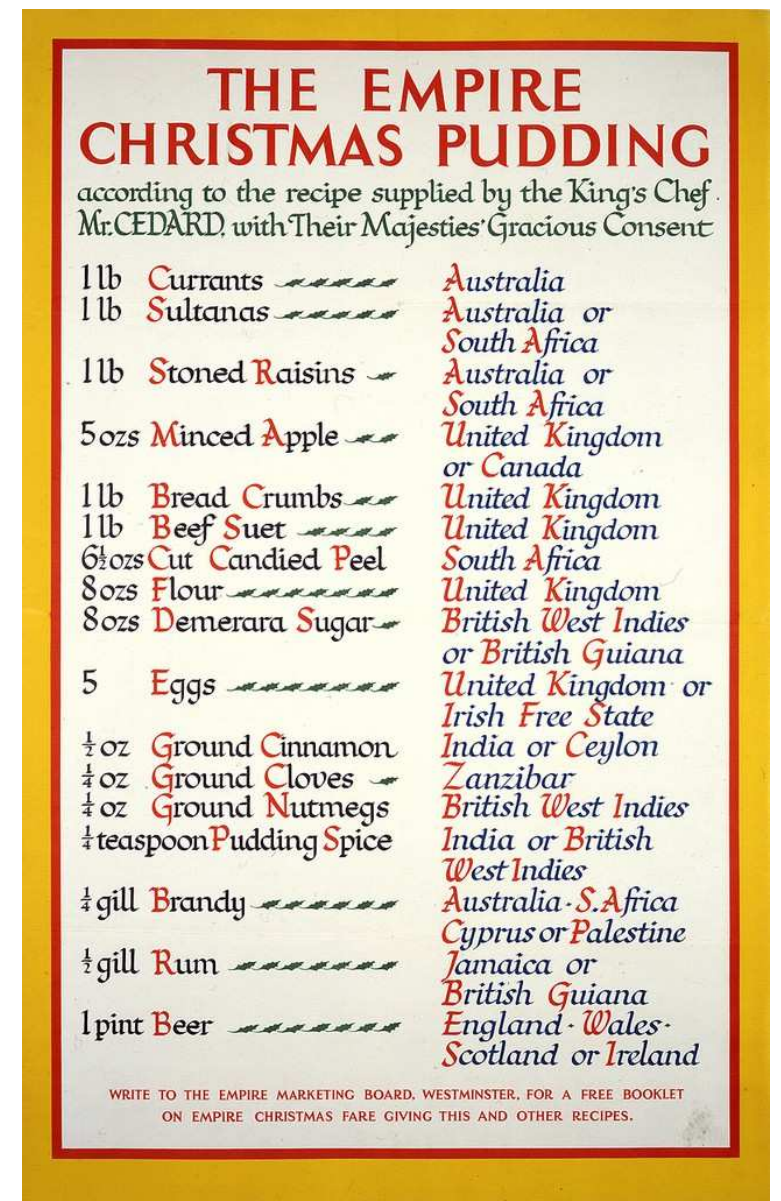

Figure 31. F.C. Harrison, The Empire Christmas Pudding: A Christmas Pudding Recipe, 1928. Lithograph, 62 X $99.2 \mathrm{~cm}$. Library and Archives Canada. Ottawa, Ontario. MIKAN 2844859. http://www.bac-

lac.gc.ca/eng/CollectionSearch/Pages/record.aspx?app=FonAndCol\&IdNumber=2844859

Despite the rhetoric espoused by the Board, some of the messages of the Board were more problematic. In the EMB's portrayals, the Empire was often essentialized to what supplies it could provide, and its depictions were not always accurate. ${ }^{375}$ The desire to portray imperial products meant depicting most of the Empire as rural, agrarian, and in development -- ignoring emerging modernity. Mike Cronin has pointed out that at the same time as Irish Free state artists were commissioned to depict rural agriculture, they were also preparing illustrations for more modern advancements,

375 David Meredith, “Imperial Images: The Empire Marketing Board, 1926-1932” History Today 37 (Jan. 1987): 32. 
like illustrating electrification projects. ${ }^{376}$ Dominions were often portrayed as the British farms of yore and urban spaces, mechanization, and protected manufacturing were rarely emphasized. ${ }^{377}$ Tim Buck has similarly has pointed out that artists depicting the African Gold Coast were more hesitant about illustrating the industrialization of the Empire, pointing out that works such as Gerald Spencer Pryce's illustration of the newly-built Takoradi Harbor was still depicted alongside many standardized tropes of exoticism. ${ }^{378}$ Alongside the rhetoric of the internationalism that the EMB portrayed was an underlying assumption about maintaining the boundaries of the developed and developing worlds, a system which the whole new order of the rested on, and which still had to be maintained to ensure British supremacy.

The EMB sought to rewrite the imperial narrative by illustrating it as a cooperative venture that would lead to stability and prosperity for the entirety of the Empire. It evoked a visual representation of the interdependence between Britain and its colonies as a "transnational moral economy." ${ }^{379}$ However, such a relationship was never about equals and was largely expressed in terms of imperial guardianship. ${ }^{380}$ Adrian Paul Allinson's Empire Tobacco from Northern Rhodesia \& Nyasaland was commissioned to help sell tobacco at a time when African producers were struggling to

\footnotetext{
${ }^{376}$ Mike Cronin, "Selling Irish Bacon: The Empire Marketing Board Artists of the Free State," Éire-Ireland 39, no 3\&4 (Fall/Winter 2004): 134-35.

377 Barnes, "Bringing the Empire Alive," 71-72.

378 Tim Buck, "Imagining Imperial Modernity in British Colonial West Africa: Gerald Spencer Pryse's Work for the Empire Marketing Board," Art History 38, no. 5 (November 2015): 960.

${ }^{379}$ Kothari, "Trade, Consumption and Development Alliances," 59.

${ }^{380}$ Frank Trentmann, "Before Fair Trade: Empire Free Trade and the Moral Economies of Food in the Modern World," Environment and Planning D: Society and Space 35, no. 6 (2007): 1085.
} 
find buyers for excess supplies. (Figure 32). Works such as those of Allinson, perhaps the most overtly paternalistic, reveal the undertones of some of the EMB's work illustrating that development and European intervention went hand-in hand. ${ }^{381}$ The EMB attempts at portraying the Empire as a family, with each part playing a role in the new project also reveal undertones of control, a civilizing mission in a new guise. Thus, the posters of the EMB become a frame of reference for seeing how the EMB envisioned its role at the time of its creation, both reaffirming certain colonial tropes and systems of underdevelopment while at the same time promoting a project of international cooperation. ${ }^{382}$

${ }^{381}$ Anandi Ramamurthy, Imperial Persuaders: Images of Africa and Asia in British Advertising, (Manchester: Manchester University Press, 2003), 144-45.

${ }^{382}$ Kothari, "Trade, Consumption and Development Alliances," 46. 


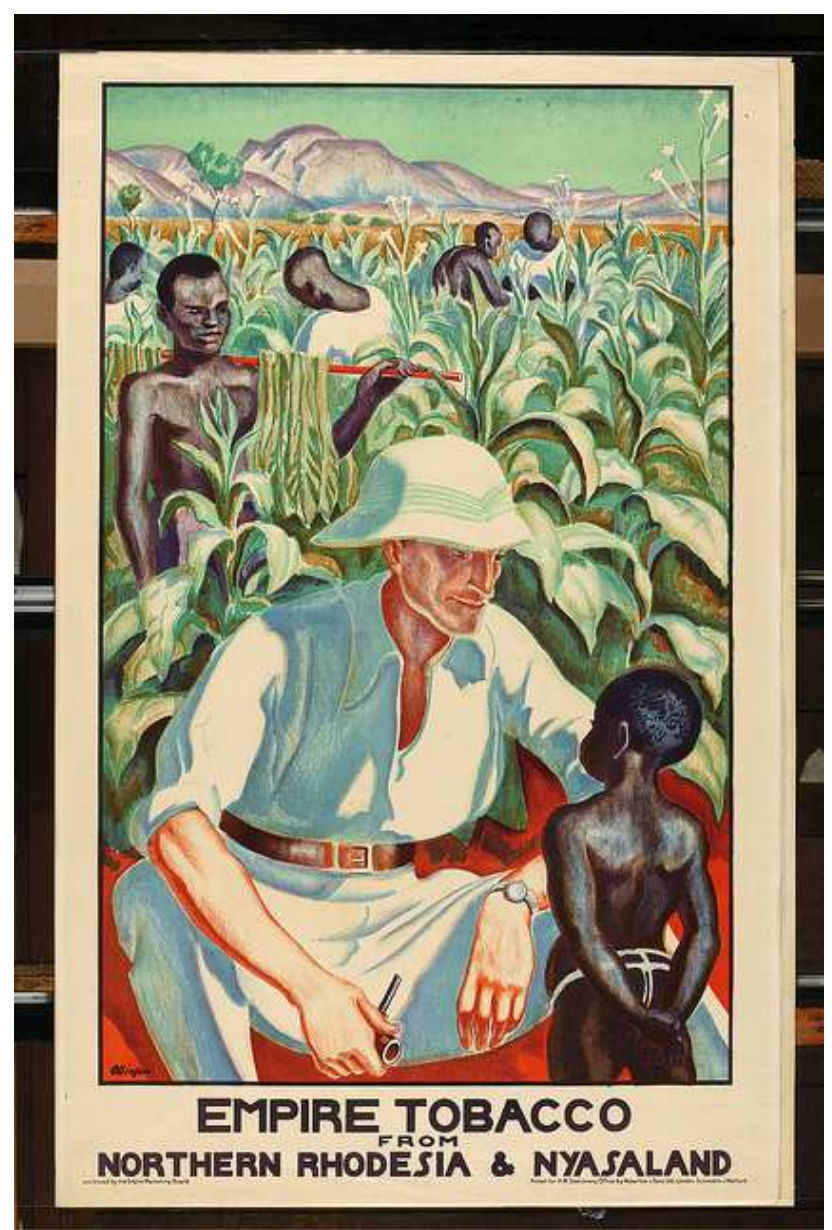

Figure 32. Adrian Paul Allinson, Empire Tobacco from Northern Rhodesia \& Nyasaland, Top Caption: Colonial Progress Bring Home Happiness. Lithograph. 102 x 64 cm. Manchester Art Gallery, Manchester, England.

https://www.flickr.com/photos/manchester_city_galleries/6811903507/in/album-72157629156638005/

\section{Propaganda Films}

In addition to the Publicity Committee's poster campaign, a Film Unit was added in 1928. Like the poster campaign, the documentaries created by the EMB represented an attempt to shape the attitudes of consumers. Tallents played a key role in the beginning of the Film Unit of the EMB. He would later note that, "We all knew that we should not have done our job properly till we had learned to employ the film for our 
purpose. But we knew also that the film was the most difficult medium of all." ${ }^{383}$ Early on, Tallents recognized the potential of film. However, given the relatively recent advancements in film technology and its infrequent government use, it was more difficult to convince other government departments of its practical utility. The rise of American film publicity encouraged the British to mobilize in a similar fashion. The U.S. Department of Commerce had noted early in the 1920s that "trade follows film" and the Bureau of Foreign and Domestic Commerce established a Motion Picture service in 1926 to help circulate information about the U.S. and American goods. ${ }^{384}$ Tallents noted that the development of American film had effectively "turned every cinema in the world into the equivalent of an American consulate." ${ }^{385}$ Calls to limit the transfer of American films and develop a more substantial film industry were seen as a way to keep pace with the emerging marketing techniques of other countries, especially the U.S. ${ }^{386}$

John Grierson, who could become celebrated as the leading figure in the development of the Documentary Film Movement in Britain - coining the term "documentary" in 1926 - was appointed head of the Film Committee and produced a number of the EMB's films. ${ }^{387}$ Grierson had previously spend $21 / 2$ years in the United States on a Rockefeller Fellowship attending the University of Chicago, where he studied the "psychology of popular appeal" and met noted figures in the American film

\footnotetext{
${ }^{383}$ Stephen Tallents, "British Documentary Films," The Spectator, November 19, 1937, 21.

${ }^{384}$ Grieveson, Cinema and the Wealth of Nations, 170-171.

385 Tallents, "Projection of England," 12.

${ }^{386}$ Grieveson, Cinema and the Wealth of Nations, 171.

${ }^{387}$ Forsyth Hardt, "Introduction," in Grierson on Documentary, 11.
} 
industry. ${ }^{388}$ Tallents was interested in his work and had Grierson write a memo to the Board about the importance of cinema. Grierson was aware of the psychological factors inherent in visual media and its power to affect popular opinion. He wrote that "cinema is recognized as having a peculiar influence in the ideological centres to which advertisement endeavors to make its appeal," that "it is an ideal medium for all manner of suggestion." 389 The interest in suggestion reflected his work in sociology and the emerging ideas of social psychology, that individuals and groups were "suggestible" and psychological and social development were formed through memetic contact with other individuals. ${ }^{390}$ Grierson looked to how imperial cooperation could be fostered and how cinema could be utilized to reach consumer consciousness. Cinema was seen as a way of reaching the masses, especially the lower-income consumers that the EMB was having the most trouble reaching. ${ }^{391}$

Film was theorized to be central in the formation of the new economic order. Grierson was interested in exploring the crux between the international and the more concrete realities of the quotidian experience, using film to allow viewers to imagine an identity within the context of international citizenship. ${ }^{392}$ Grierson envisioned using films to portray both the dynamism and the social realism of the everyday, helping to render

\footnotetext{
388 Stephen Tallents, “Empire Marketing Board Note," April 29, 1927, TNA BT 64/86 389 John Grierson, Notes for English Producers Part I. TNA BT 64/86, 1.

${ }^{390}$ Grieveson, Cinema and the Wealth of Nations, 181.

${ }^{391}$ Nadine Chan, 'Remember the Empire, Filled with Your Cousins:' Poetic Exposition in the Documentaries of the Empire Marketing Board." Studies in Documentary Film 7, no. 2 (2013): 109.

${ }^{392}$ Rob Aitken, "Provincializing Embedded Liberalism: Film, Orientalism and the Reconstruction of World Order," Review of International Studies 37 (2011): 1703-1704.
} 
"the visually dramatic material in which the Empire is so rich," in the form of "the sweep of commerce ... the ships, the docks, the factories, the furnaces, the streets, the canals, the planes, the plantations, the caravans, the parades, the dams, the bridges...that carry the flag of English energy." ${ }^{393}$ The dynamic vitality of the British Empire was thought be ripe for visual representation. Cinema and development were seen as central to helping move the Empire forward. The need to create infrastructure to facilitate imperial economies and rationalize production were part of the "new order," a way of reimaging the Empire and rendering its new visual form.

Grierson also illustrated how that reimagining was theorized. He noted, like others, that the idea of the Board was to change the perception of Empire in the public consciousness. The Board's aim was:

to change the connotation of the world "Empire." Our original command of people was becoming slowly a cooperative effort in the tilling of soil, the reaping of harvests, and the organization of a world economy. For the old flags of exploitation, it substituted the new flags of common labour; for old frontiers of conquest it substituted the new frontier of research and world-wide organization. ${ }^{394}$

He reaffirmed the remaking of Empire as a cooperative project, that each part of the Empire would play a role in the new imperial economy. Grierson, however noted that people had "become more and more citizens of a community which we do not adequately see. ${ }^{~} 395$ It became important to visually render the entirety of the Empire, to show

393 John Grierson, Notes for English Producers Part II, 7. TNA BT 64/86.

${ }^{394}$ John Grierson, "The E.M.B. Film Unit," in Grierson on Documentary ed. Forsyth Hardy (London: Faber and Faber, 1996), 165-66.

395 John Grierson, "The Challenge of Peace" in Grierson on Documentary ed. Forsyth Hardy (London: Faber and Faber, 1996), 325. 
consumers what the Empire truly looked like, in order to make the conceptual idea of Empire tangible.

Early films by the EMB were mainly short films. In mid-1928, the EMB began to use automatic projectors in public spaces to show short "poster films," as Tallents would deem them, which advertised imperial produce. The poster film Canadian Apples, Lumber, and South African Fruit, for example, functioned as short advertisements for Empire products. ${ }^{396}$ A projector was installed for viewing such proto-commercials at Victoria Station, a traveling cinema van and projector was lent to the Leicestershire County Council -- allowing rural populations outside of London to see EMB films - and a number of films began to be shown at EMB exhibitions. ${ }^{397}$ Such efforts had been utilized in the Soviet Union as a method of reaching rural populations and spreading the Bolshevik message to the countryside where Party support was weaker. ${ }^{398}$ The EMB committee, well aware of Soviet advancement in film technique and distribution, hoped to accomplish something similar in using film to propagate the importance of the British Empire. EMB films would work both as advertisements for specific products and for the idea of "Empire" more broadly.

The Board also explored new networks of film distribution. It had begun to explore new methods of display in schools and factories. Additionally, a film library

${ }^{396}$ Lee Grieveson, "Empire Marketing Board," Colonial Film: Moving Images of the British Empire. 2008. http://www.colonialfilm.org.uk/productioncompany/empire- marketing-board ${ }^{397}$ Stephen Tallents, "The Birth of the British Documentary (Part I)" Journal of the University Film Association 20: no. 1 (1968): 19.

${ }^{398}$ Peter Kenez, The Birth of the Propaganda State: Soviet Methods of Mass Mobilization 1917-1929 (Cambridge: Cambridge University Press, 1985), 220. 
was established at the Imperial Institute with films donated from the Canadian Government and the Canadian National Railway, who both maintained their archives in London. These films were often in demand among schools, training colleges, film societies and relief organizations. In 1931, 350 organizations had begun to use the film library, and supplies and users tripled the following year. ${ }^{399}$ The Institutes' visitors numbered 180,000 , a third of which were school children, and totally distribution was thought to reach 800,000 by $1932 .{ }^{400}$ The utilization of film was designed to combat domestic and colonial political and economic concerns and shifting trade and power, to increase cooperation among Dominions, and to assert power and status vis-à-vis the emerging power of growing nations, most notably the United States. ${ }^{401}$

However, plans were also being put into motion for larger-scale cinematic works. In February 1927, Tallents called together the Board's first film caucus, at which he presented a scenario written by Rudyard Kipling and Walter Creighton for a featurelength fiction film that would be suitable for the EMB's purposes. Creighton had produced the Wembley Tattoo at the 1924 British Empire Exhibition with help from Kipling and was thus well versed in the production of imperial spectacle. Walter

399 Stephen Tallents, "The Birth of the British Documentary (Part II)" Journal of the University Film Association 20, no. 2 (1968): 29.

400 Tallents would continue to oversee the film library after the EMB's demise. After the EMB, Tallents took the library with him to the General Post Office, where many filmmakers involved in with the EMB would also go - producing films, and eventually to the Ministry of Information, which the library became the base for its non-theatrical destruction. See Tallents, "The Birth of the British Documentary (Part II)" 29. ${ }^{401}$ Lee Grieveson, "The Cinema and the (Common) Wealth of Nations," in Empire and Film, ed. Lee Grieveson and Colin MacCabe (London: Palgrave Macmillan on Behalf of the British Film Institute, 2011), 73. 
Creighton was appointed to the Board in March, with the support of Amery. Creighton had no actual knowledge of film production, and was employed because of his connection with Kipling, whose fame and association with imperial storytelling would, it was thought, help guarantee the film's success. Although the Empire Marketing Board sanctioned One Family and John Grierson's own film on herring fishing - Drifters - as its first two productions, Tallents had more trouble convincing the Treasury of their importance. ${ }^{402}$ The Treasury finally greenlit both films on April 27, 1928 at a meeting in Whitehall attended by Tallents and Amery.

Creighton's 1930 film One Family, co-written by Kipling, illustrates a fictional story in which a London schoolboy dreams of visiting Buckingham Palace, where he makes the King's Christmas pudding from ingredients collected from different parts of the Empire. On his way to school, the boy passes a large shop window, which advertises "The Empire's Offering" and displays the ingredients for “The King's Christmas Pudding," recalling Harrison's printed poster version. A policeman tells the boy to get to school and he hurries off, arriving late. The boy, bored by his geography lesson featuring Gill's map of empire, falls asleep and begins to dream. In his dream, the policeman tells the boy to go to Buckingham Place. There, he visits the King and the "Dominions" - India, New Zealand, Canada, Australia, South Africa and Irish Free State - personified by noted British socialites - in the council chamber. On his return home, the boy is delighted to see his mother baking

\footnotetext{
${ }^{402}$ Stephen Tallents, "Birth of the British Documentary (Part 1)" Journal of the University Film Association 20, no. 1 (1968): 17.
} 
the Empire pudding and comes to the realization that the Dominions are "a family too. ${ }^{403}$ Christmas carols play as the film concludes with shots of St. Paul's Cathedral and Westminster at night.

Though considerable effort and money were put into the production of One Family, the film failed to reach a mass audience. The film premiered at the Palace Theater on July 7, 1930, but only ran for one week. ${ }^{404}$ Despite the film's capitalization on the familiar association of the Christmas pudding that was portrayed in print, the film failed to connect with viewers. Grierson explained the failings as he saw them in 1931, stating that the "dreams of real things" - a reference to One Family's subtitle "which Creighton made was not quite the dream which the film public was accustomed to turn over in their minds... The lesson we learned was that cinema can only at peril depart from the dreams and aspirations of common people." 405 Nadine Chan notes that the film, with its "exploitative attitude," was still too expressly paternalistic. ${ }^{406}$ Its heavy-handed symbolic message did not interest the general population. What was needed, in addition to a less abstracted concept, was one that would be able have enough emotional appeal to resonate with the masses

Grierson's documentary, Drifters, varied somewhat in its aims toward social realism rather than the obvert sentimentality that had doomed One Family. Drifters, often regarded as the first documentary, illustrates through montage and action shots the

\footnotetext{
${ }^{403}$ Grieveson, "The Cinema and the (Common) Wealth of Nations," 97.

404 Tallents, "The Birth of British Documentary (Part I)", 21.

${ }^{405}$ Empire Marketing Board, "Annual Report on the Activities of the EMB Film Unit," 1931.

${ }^{406}$ Nadine Chan, "'Remember the Empire Filled with Your Cousins,"” 110.
} 
day- to-day existence of North Sea Herring fisherman. It captures the productive capabilities of British industry through its humanistic focus. Drifters premiered on November 10, 1929. It was shown at the Tivoli Theater before a screening of Eisenstein's Battleship Potemkin, which Grierson admired for its realism and innovative style. Tallents recalled that the film sought to do away with the escapist approach that had permeated contemporary filmmaking. Recalling Grierson, Tallents noted, "It did not seek to spirit everyone away from real everyday life to dreams. It had no snob appeal...It took as its raw material the day-to-day life of ordinary men and from that neglected vein won interest, dignity and beauty." ${ }^{407}$ Similarly, The Times raved, "Mr. Grierson's work gives the impressions in film theatres, that having substance and truth and imagination in it, it will survive its own day, as indeed his Drifters has survived, being still in demand for public exhibition. ${ }^{, 408}$ The Film Unit recognized that the documentary would be the model to adopt for future films, as it garnered more viewers than the fictional narrative style of One Family.

The success of the film, and its recouped costs, justified further expenditure on the part of the Treasury for future films. Grierson was then made Assistant Film Office to the EMB. Grierson was quick to note that, "There is money for films

407 Ibid.

408 Our Dramatic Critic. "Films of Substance." The Times. April 2, 1932. 
which will make box-office profits, and there is money for films which will create propaganda results. These only." ${ }^{, 409}$ Despite Grierson's relative freedom from government control in creating films with the Film Unit, he was also acutely aware that his own agenda had to be put in line with government aims. Though he was influenced by the Soviet traditions of film, which stressed the importance of the everyman, Martin Stollery points out that Grierson had to be careful not to over assert his sympathies as, "even the faint possibility that an EMB production might be perceived as critical of imperialism was something which Grierson, as head of an official institution, had to handle with extreme care. ${ }^{, 410}$ In the Film Unit, as in elsewhere, propaganda efforts required maintaining of a careful balance among varying interests.

Other films produced after its initial two further reference the themes of the EMB's posters. Cargo from Jamaica (1933), for example, directed by Basil Wright, illustrated the harvesting of bananas and their transport on the heads of colonial subjects, to be manually loaded onto large ships. Like Pears' Suez Canal, the imagery of Cargo illustrates a juxtaposition between old and new. ${ }^{411}$ The use of ships represented not only a reverence for technology and transport but served as symbols of

${ }^{409}$ Grierson, "The E.M.B. Film Unit;" 165-66.

${ }^{410}$ Martin Stollery, Alternative Empires: European Modernist Cinemas and Cultures of Imperialism (Exeter: University of Exeter Press, 2000), 177

${ }^{411}$ This was a common theme in Soviet films as well. Directors associated with the EMB, such as Grierson and Wright, were influenced by Soviet films such as Victor Turin's documentary Turskib, depicting the building of the railway between Siberia and Turkistan. Stephen Tallents recalled meeting Turin at a showing of the film in London. Wright would later implement some of Turin's motifs in his 1936 film, Night Mail, a documentary film - narrated by Grierson - for the General Post Office depicting postal trains traveling from London to Glasgow. See Tallents, "The Birth of British Documentary (Part I)," 19. 
the British finance that sustained the shipping industry and, thus, British economic control of the global circulation of materials and goods. ${ }^{412}$ Arriving in London, conveyor belts from the ships to warehouses transport the cargo efficiently. The contrast between the use of human labor and technology mark a contrast between an advanced technological modernity and the economies of colonized laborers and agricultural producers. The film asserts British strength by contrasting it with production methods of the colonies, but always under the rhetoric of a mutual symbiosis.

Another of its films, Windmill in Barbados (1933) - illustrating the production of sugar cane in the West Indies - similarly contrasts old and new methods of production. Over a map of Barbados, a West Indian voiceover outlines a history of the island saying, "Barbados is the only island which has always remained British since its settlement in the name of King James," and explains that, "today the sugar industry is the most important in Barbados." Shots of the sea and beach are followed by footage of workers in the cane fields - supervised by men on horseback. The workers load cane branches onto carts, as the voiceover explains that they, "have been grinding cane the same way for two centuries." The carts approach the windmill and workers operate it by hand, while others transport the cane on their heads into the mill. The film then highlights modern developments noting, "Machines and new ways of working are a great improvement and we are helping to bring them all over Barbados," illustrating increasing production and trade that might be furthered through modern methods. As is

${ }^{412}$ Chan, "'Remember the Empire Filled with Your Cousins,"” 112. 
evident in other mediums, the films illustrate mechanized domination, but under the assertion that it would be by working together, bridging the gap between old and new, that the Empire would see greater prosperity.

The films of the EMB represented a complicated and conflicting view of Empire. The EMB's staff believed that they were engaged in a democratizing project. The Empire was conceived of as a model economic unit of the future. Like the posters, the films, though more nuanced in their presentation, presented both orientalist fantasy and a conception of a new "world order" - which has spawned debate as to the true undercurrents of the EMB films in terms of internationalism. ${ }^{413}$ The films illustrate the conflicting nature of promoting imperial cooperation alongside the framework of imperialism that perpetuated underdevelopment of the colonies. ${ }^{414}$ Rob Aiken notes the "post-war world order," still, "invokes a notion of historical and colonial difference but seeks to close that difference by marking out...the universal space of a new social economy." ${ }^{, 45}$ The message of the films simultaneously reinforce colonial divisions while

${ }^{413}$ Films such as Windmill in Barbados have been read, on the one hand, as a promotion of imperial trade and as an endorsement of the work of the British in the Caribbean. However, the film has also be read as a critique of British imperialism. Sight and Sound's review praised Wright for bringing, "a sense of poetic imagery to bear upon the inevitable tragedy of the old and new," and noted the, "undercurrent of sympathy for the negro worker, the sons of slaves, revealed in a sudden flash from the native laborers to half caste employer, grown rich on cheap labor and aping European customs and clothes ${ }^{43}$ Wright acknowledged that the dockside scenes in Cargo from Jamaica were filmed to show "the toil and sweat involved in this particular work - and indeed, the exploitation." See, "Windmill in Barbados." Sight and Sound (Autumn 1933), 103; Stollery, Alternative Empires, 178

${ }^{414}$ Nadine Chan, "'Remember the Empire Filled with Your Cousins,"” 115.

415 This paralleled similar internationalist agendas such as the standardization of time, money, weights and measures, as well as communications and transportation. The universalism of film for educational purposes was thought to have a similar unifying effect. See Zoe Druick “'Reaching the Multimillions': Liberal Internationalism and 
still emphasizing the ideas of collectivity and cooperation. The attempt to rebrand the Empire as a more benign Commonwealth illustrate projections of Empire at the time, but the underlying basis for the framework of the Empire still affirmed and reinforced traditional imperial roles.

\section{Other Publicity Efforts}

The EMB also utilized other resources to encourage Empire shopping beyond posters and films. The press was another of the resources utilized by the EMB. The Board's experience in market research had also helped to inform their publicity efforts. The press advertisements that were utilized by the Board were differentiated between different publications. "Class A" papers such as the Times emphasized economic and cultural themes in their advertisements. "Class B" papers such as the Daily Mail focused on commodities. "Class C papers such as News of the World and John Bull, and "Class D" papers which focused on women's newspapers like Good Housekeeping received "gossipy" advertisements that were focused on dialogue, "Class E" papers targeting the working class and the Labour Party emphasized the importance of Empire commodities from a working class perspective that focused on the necessity of employment, and "Class F" papers targeted trade papers that appealed to store owners to stock products. ${ }^{416}$ The London Press Exchange also helped to supply the EMB with

the Establishment of Documentary Film," in Inventing Film Studies, ed. Lee Grieveson and Haidee Wasson (Durham: Duke University Press, 2008); Rob Aiken, "Provincializing Embedded Liberalism: Film, Orientalism, and the Reconstruction of World Order." Review of International Studies 37, no. 4 (May 2011): 1698; 1715. ${ }^{416}$ Schwarzkopf, "The State as Market Researcher," 9. 
surveys of retailers, who pointed out that the sale of Empire goods had increased in higher class shops but that demand should be encouraged, "increasing the demand in the cheaper side of the trade." ${ }^{417}$

Shopping was also encouraged at exhibitions, shopping weeks, and Empire stores. The Board advertised products at exhibitions such as the British Industries Fair, Imperial Fruit Show, The Baker's and Confectioners' Exhibition, the Ideal Home Exhibition. There was also attempts to set up shopping exhibitions in other cities throughout Britain. The Belfast Empire Week Exhibition, Edinburgh Imperial Exhibition, Liverpool Commerce and Industry Exhibition, and others in Birmingham, Norwich, Cardiff reflected some of their efforts. Sponsored shopping weeks were also furthered to encourage the sale of Empire products. The Board encouraged retailers to use advertisements on their windows provided by the Board. Two hundred different shopping weeks were sponsored in 65 towns in $1930 .{ }^{418}$ Fifty different designs were designed for shop windows and seven million were printed in total. ${ }^{419}$ Prizes were even awarded for the best window designs. The creation of empire shops was another of its projects. The EMB developed a system of taking shops in cities and opening them up to Empire producers on a rotating basis. For a period of time, a given shop would advertise a certain Empire country's product. The first shops were initiated in Edinburgh, and more were also sought in other cities. It was noted that interest often

\footnotetext{
${ }^{417}$ Meeting. EMB Publicity Committee, June 27, 1928, TNA CO 760/23

${ }^{418}$ Constantine, "Bringing the Empire Alive," 207. ${ }^{419}$ Ibid.
} 
tapered off after two weeks when the next country's goods were rotated in. ${ }^{420}$

The EMB also sponsored public lectures. Lecturers approved by the EMB spoke to women's organizations, the YMCA, literary societies, co-ops, schools, working men's clubs, trade colleges, Rotary Clubs and Grocers Associations. Precautions were taken against lectures that might contain "inappropriate or contentious matter," and had to be approved beforehand. ${ }^{421}$ The EMB started the lecture series in 1927 and by 1929 it had given around 2,400 lectures to over 500,000 people on topics such as "The British Empire and What it Means to You," "Airways of Empire," "Economies of Our Empire," and those on specific parts of the Empire such as "lower Burma and its Pearl Fisheries," "Life in the British West Indies," and "Rhodesia, the Land of Promise." 422 By further illustrating the Empire and how it connected to consumers it Britain, it was hoped that citizens at home would be further motivated to buy from the Empire.

The EMB was also receptive to the idea of radio and its usage to reach a mass audience. BBC representatives had been a part of the EMB's Publicity Committee. Its first meeting was attended by Gladstone Murray, who served as Director of Public Relations at the BBC from 1924-1935. By 1928, EMB morning programs were broadcasted every week or every other week to advertise Empire produce and recipes. The EMB was advised to focus their radio programming to the morning hours, as that

\footnotetext{
${ }^{420}$ Meeting of the EMB Publicity Committee, March 6, 1930, TNA CO 760/23

${ }^{421}$ Meeting EMB Publicity Committee, June 7, 1927 TNA CO 760/23

${ }^{422}$ Constantine, "Bringing the Empire Alive," 204-205.
} 
was when housewives were more apt to listen to the radio. ${ }^{423}$ In 1930 a series, "Where Your Goods Comes From," was broadcast illustrating different food products from the Dominions and India. On Empire Day in 1930 a special program "How the Sun Never Sets" was designed, producers noted, to be "a sort of audible version of a series of Empire Marketing Board posters," educating consumers on more of the Empire's geographic and economic assets. ${ }^{424}$ In addition, in 1931 a series of short talks on the BBC were conducted by Professor John Coarmas, whose chair in Imperial Economic Relations at the London School of Economics was funded by the EMB. The theme of "The Empire and Ourselves" was designed to make academic subject matter available to the public, further illustrating instructive advertising on the importance of Empire goods and their purchase.

The Board also realized the value of educating school children in their aims. Educating the next generation on the importance of buying imperially was an essential part of the EMB's work. Early on, the Publicity Committee explored how schoolchildren and teachers might be reached. In 1930, the Board wrote that "if the habit of Empire buying is to be permanently established, educational publicity is essential." The Board established an Education Subcommittee to its Publicity Committee, which was chaired by Sir William Furse, the Director of the Imperial Institute, and included Stobard of the BBC and representative from the Board of Education and the Scottish Education Department. Schools throughout Britain made requests for posters and

${ }^{423}$ Meeting. EMB Publicity Committee, March 27, 1929, TNA CO 760/23

${ }^{424}$ Constantine, "Bringing the Empire Alive," 207. 
information. By 1933, 27,00 schools were on its mailing list for informational materials. ${ }^{425}$ Posters that had an educational function were proposed for reproduction for school use. ${ }^{426}$ The use of public lectures and film were also utilized to target school-age audiences. Because film projectors were prohibitively expensive for school use, schools in cities were encouraged to attend cinemas showing EMB films. In London, the Imperial Institute - which received funding for a new cinema - was utilized to show educational materials to schoolchildren. It was hoped that by illustrating the patriotic appeal of imperial cooperation, it would help mold the shopping habits of the next generation of consumers.

\section{$\underline{\text { Conclusion }}$}

The publicity work of the Board centered around convincing consumers that buying Empire products would help industries both at home and throughout the Empire. The EMB sought to encourage consumers to reimagine their place within the new cooperative project of Empire. Posters, films, shopping weeks, lectures, and radio programs all sought to educate the public on the places that made up the Empire and which products could be purchased from it. It also looked forward to the next generation of consumers as it sought to educate children on the vital necessity of collaboration between home and Empire. Women and the working class became a new political demographic, with the enlargement of the franchise, that were increasingly called upon to

${ }^{425}$ Constantine, "Bringing the Empire Alive," 212.

${ }^{426}$ Meeting. EMB Publicity Committee, April 24, 1929, TNA CO 760/23 
help further the imperial cause. However, their benign depictions also concealed the changing nature of the British social sphere as new groups gained more political influence.

The Board espoused a vision of imperial collaboration, but its conceptions largely meant colonialism in a new guise. Ongoing questions about the legitimacy of Empire meant a need to rethink how to portray a new imperial narrative that might be more palatable to consumers. However, the visual media produced by the EMB still reaffirmed hierarchies between Britain and the rest of the Empire. The Dominions and colonies were still looked to for what commodities they might provide, without consideration of how or when they might also industrialize themselves. Depictions of colonial workers as content and nonthreatening, also concealed the true coercive practices that workers could be subjected to and the insurrections that occurred when they tried to protest against maltreatment. The model that the EMB projected only worked as long as the Empire remained producers of primary products and Britain remained the industrial power. The EMB's vision was built on a presumption of British dominance, but such as vision was not sustainable in the long term. For that reason, the EMB's publicity work was largely more fantasy than fact and signaled the incongruity between the Board's conceptualizations and the true state of affairs during the interwar period. 


\section{Epilogue}

For all of its efforts, the work of the Empire Marketing Board eventually ceased operations in 1933. The reason for the EMB's termination was in large part due to the onset of the Great Depression and the need for economization as a result. Domestic concerns such as mass unemployment and the abandonment of the gold standard meant a new economic reality in Britain, which necessitated the formation of a bipartisan National Government to provide a unified strategy for the dire economic situation. The government had proposed ending the Board as early as 1930 to help balance the budget but it was narrowly saved from termination, though it had to carry on with a limited budget. The Import Duties Act of 1932 formally put an end to Britain's longstanding policy of free trade, establishing a 10 percent tariff on goods. The bill was introduced to the House of Commons in February by MP Neville Chamberlain, son to the noted tariff reformer Joseph Chamberlain.

The League of Nations had held conferences in the late 1920's, culminating in the "Tariff Truce" conference of 1930, to try to prevent the rise of tariffs but it had largely failed. The rise in protectionism had seen tariffs increase in Germany, France, Italy, Austria, Czechoslovakia, Spain, and the United States. When the Smoot Hawley Tariffs were enacted by the United States in 1930, the largest in US history, it led to retaliatory tariffs in Japan, Australia, Canada, and New Zealand. By this point a more unified front had developed in favor of introducing tariffs in Britain in order to help economic recovery. Conservatives continued their long campaign for preferences, again propagating the idea that the influx of foreign goods were harming domestic workers. They also emphasized the relief, "the brighter days," that would result from the move 
away from Britain's traditional free trade policy (Fig. 33). Industrial coalitions, organized labor, and banking interests increasingly looked to tariffs as a means of facilitating modernization efforts that could help them to keep pace with world competition. The end of free trade and the push for preferences between Britain and the Dominions went handin-hand with Britain's decline as a world power. When it was at the height of power, Britain regarded tariffs as crutches that an imperial power did not need, but as its global reach and influence wavered, the implementation of tariffs became imperative.

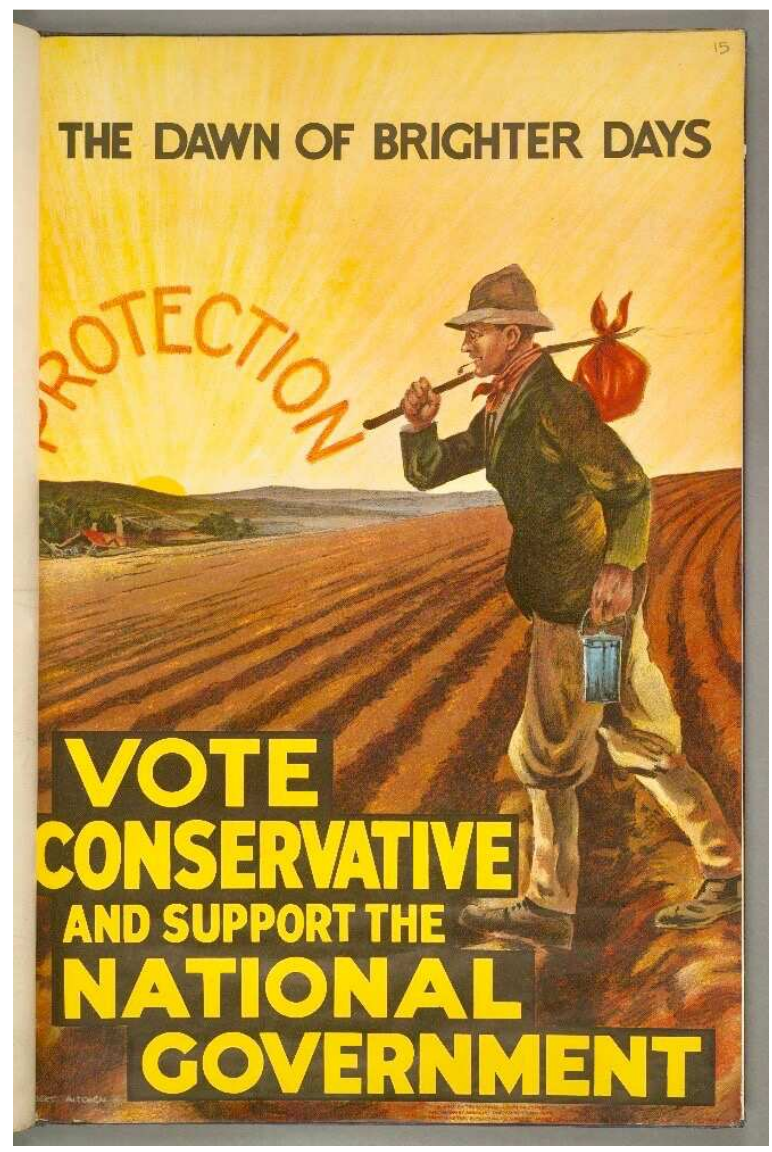




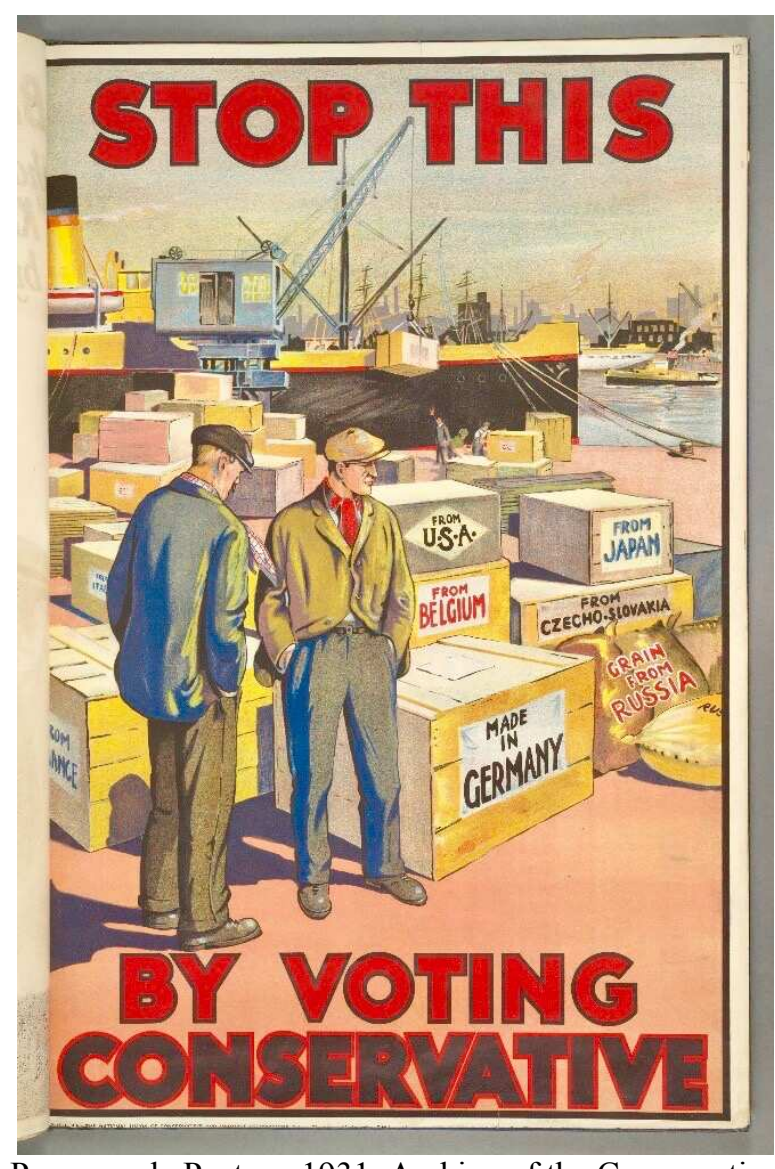

Figure 33. Conservative Propaganda Posters. 1931. Archive of the Conservative Party. Bodleian Library. https://digital.bodleian.ox.ac.uk/inquire/Discover/Search/\#/? p=c+2,t+ox_lunaCollectionId\%3A\%226\%22,r $\underline{\text { srs }+100, \text { rsps }+10, \text { fa }+, \text { so }+ \text { ox } \% 3 \text { Asort } \% 5 \text { Easc, scids }+, \text { pid }+, \text { vi }+}$

At the 1933 Imperial Economic Conference, convened by Britain and Dominion representatives in Ottawa, both Britain and the Dominions sought out an economic agreement on preferential tariffs. The Board had been established to avoid such measures, but with new tariffs in place there was little need for the voluntary measures that the EMB encouraged. The Dominions refused to contribute funds for the EMB's upkeep, which was proposed to them at Ottawa. The Dominions had always preferred a tariff change to public persuasion. Some interests in Canada, South Africa, and the Irish Free State had been especially desirous to affirm their autonomy and were suspicious of more 
centralized bodies like the EMB ${ }^{427}$ With its ongoing production and budgetary problems, the unwillingness of the Dominions to shoulder the cost of further propaganda efforts, and the economic collapse of the Depression the Board finally folded after its seven-year tenure. The protectionist strategies suggested by Conservatives decades before were finally put into practice. Free trade and internationalism were out of fashion. In the wake of economic crisis, countries instead made moves to take care of their own.
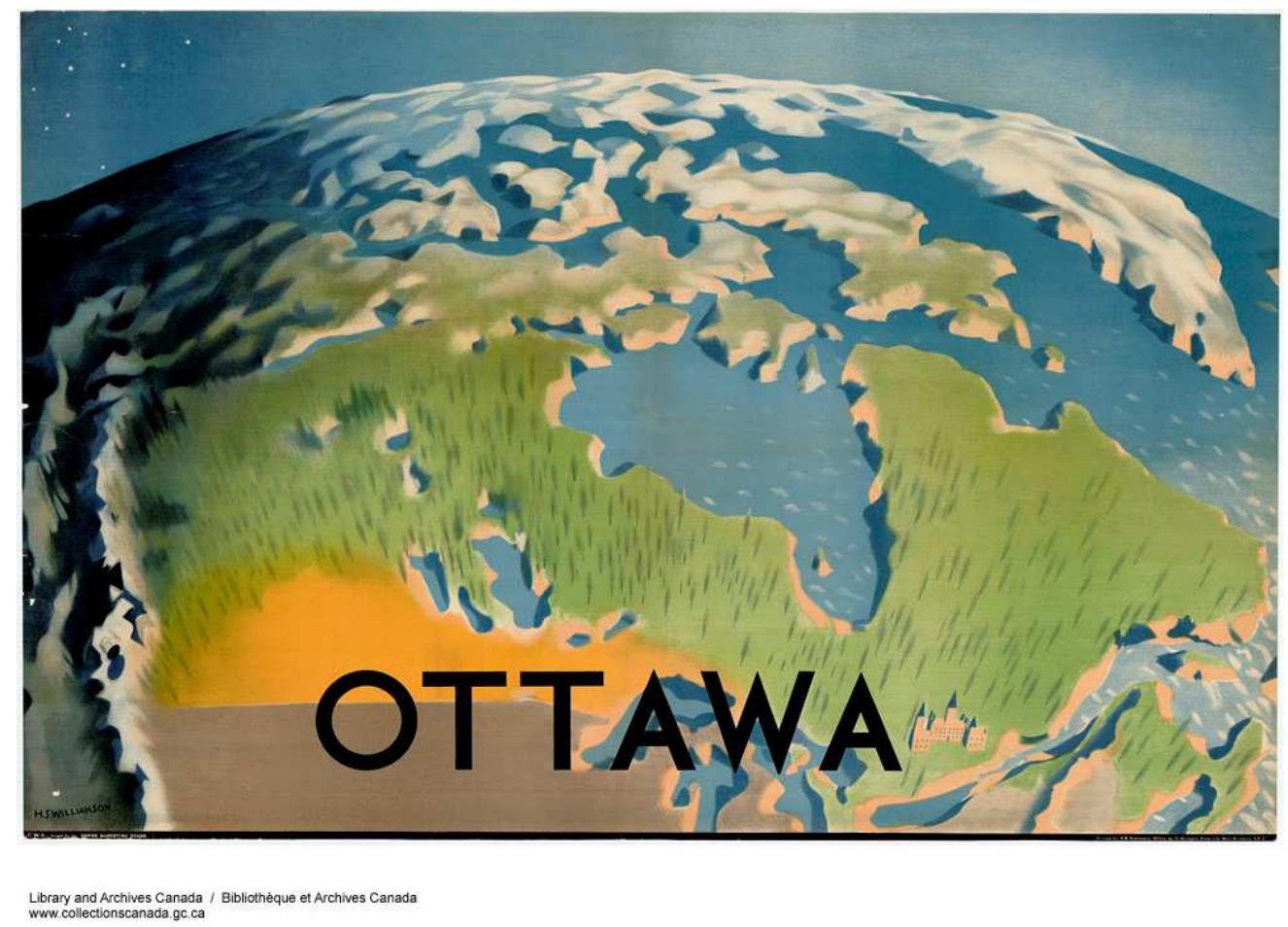

Figure 34. Harold Sanders Williamson. Ottawa. Lithograph, 151 x $100.9 \mathrm{~cm}$. Library and Archives Canada. Ottawa, Ontario. MIKAN $2845121 \mathrm{http} / / / \mathrm{www} \cdot \mathrm{bac}-$ lac.gc.ca/eng/CollectionSearch/Pages/record.aspx?app=FonAndCol\&IdNumber=2845121

The Ottawa Agreements signaled new national concerns that took precedence over imperial ones. At Ottawa, Britain negotiated new bilateral agreements with each of

${ }^{427}$ Constantine, "Bringing the Empire Alive," 220. 
its tariff-autonomous Dominions - Australia, Canada, New Zealand, Newfoundland, South Africa, India, and Southern Rhodesia. However, Dominion negotiators fought for concessions that would benefit their exports while making few concessions to Britain, a move which surprised British delegates. ${ }^{428}$ Within the context of world economic decline, the promotion of Dominion interests helped to signal their further autonomy. Dominions largely increased the already-existing margins of preference on commodities, while Britain exempted imports from signatory countries from duties under the Import Duties Act. The Agreements led to an overall increase in Empire-wide trade, rising from $29 \%$ in 1931 to $40 \%$ by 1938 . But it did so largely at the expense of world trade and fell short of the cooperative vision espoused by the EMB.

The EMB's international vision of the 1920s represented a moment in time when it seemed possible to encourage greater imperial cooperation and sell the Empire as an international cooperative project. With its demise, as Chan notes, "the fantasy of the cosmopolitan Commonwealth family no longer had its place." ${ }^{429}$ Though international cooperation did not disappear, it was significantly challenged by the events of the Depression. Similarly, the rising nationalist movement abroad began to forecast the splintering of the Empire. Despite imperial internationalists attempts at portraying an interconnected and mutually-supportive Commonwealth (Fig. 35), the ideas that underwrote the assumptions relied on the underdevelopment of the Empire, which led to protest and emerging nationalist movements throughout the colonies of the Empire. The

${ }^{428}$ Francine McKenzie, Redefining the Bonds of Commonwealth, 1939-1948: The Politics of Preference (New York, Palgrave Macmillan, 2002), 20.

429 Chan, "'Remember the Empire Filled with Your Cousins,", 115. 
rising nationalist sentiments challenged the projection of internationalism that the EMB had sought to propagate.

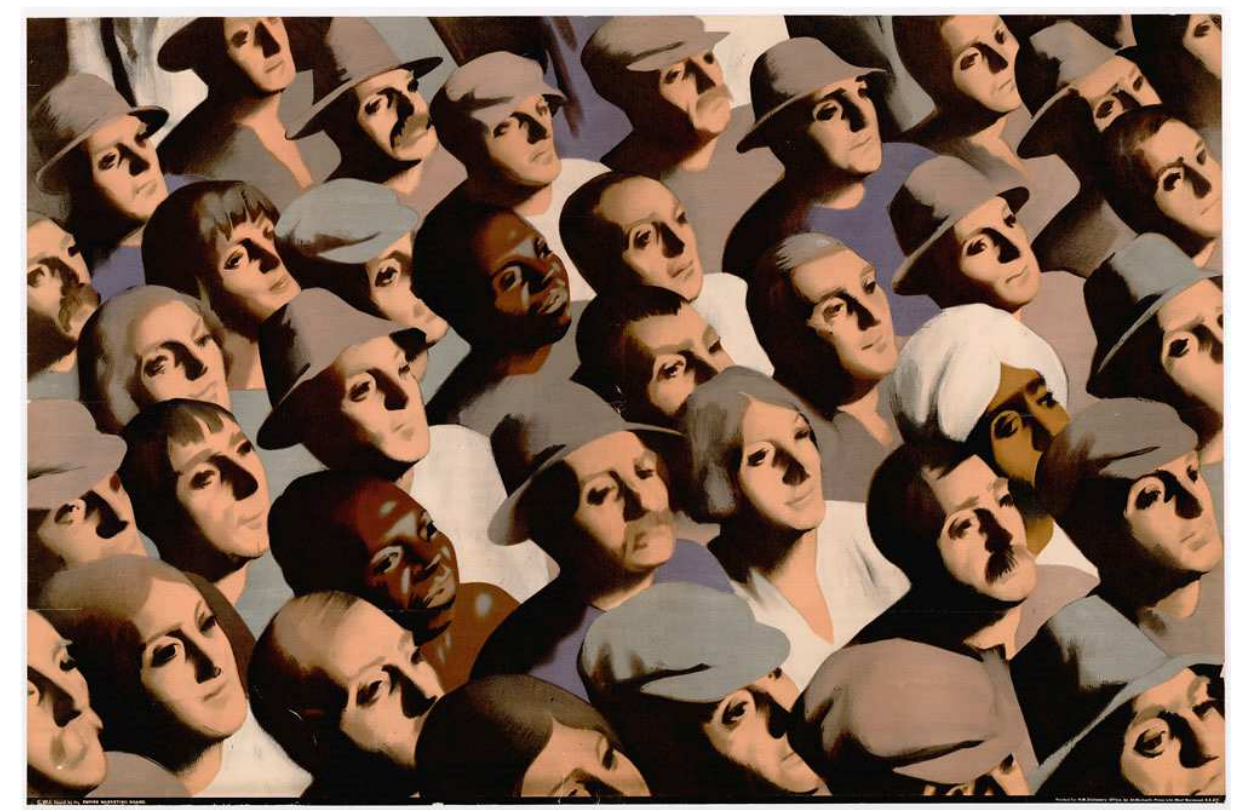

Library and Archives Canada / Bibliothéque et Archives Canada

Figure 35. Harold Sanders Williamson. Faces of the Empire. Lithograph. 151.8 x $101 \mathrm{~cm}$. Library and Archives Canada. Ottawa, Ontario. MIKAN 2845304.

https://www.flickr.com/photos/manchester_city_galleries/6811262477/in/album-72157629154741557/

The EMB had faced a slew of criticisms throughout its tenure, so it came as little surprise to some that when cost cutting measures were sought, the Board was terminated. The cost of the Board had been a perpetual concern. This largely had to do with debates with the Treasury over funding concerns, as it was difficult to quantify how effective the various propaganda campaigns were or how its efforts affected consumption habits.

Tallents recalled that, "the feeling was discernable that we were introducing a discreditable element in to Whitehall." The Board, "felt itself sometimes the unwanted 
child in the Government service." ${ }^{230}$ The orthodox belief that balanced budget, tax cuts, and reduced government expenses would solve economic problems lead to the call for streamlining of government services. ${ }^{431}$ The novelty of publicity seemed too big a luxury to be justified in a time of financial distress.

One of the key issues was that there was no way to prove that the money put into the cultivation and promotion of imperial products had any effect on sales. Any increase could be attributed to many different causes. Committee reports illustrated a concern for such a large budgetary expenditure for marketing attempts that could not directly prove their use. ${ }^{432}$ The Times noted, of the Board's posters, that "publicity work is seldom susceptible of exact measurement, and critics have not been lacking to suggest that the posters of the Board, however ornamental as additions to the amenities of the streets, could have little practical effect on sales." ${ }^{" 433}$ Films, though culturally influential, could be measured in terms of viewers but could not be proved to translate into the purchasing of empire products. ${ }^{434}$ The EMB was put at a considerable disadvantage by lacking any mechanism that would directly prove that their efforts worked, which could justify their continuance.

As we have seen, a number of issues also presented themselves as the EMB tried to encourage imperial consumption. As its scientific efforts illustrated, growing and

\footnotetext{
${ }^{430}$ Constantine, "Bringing the Empire Alive," 219.

${ }^{431}$ Ibid.

432 The EMB only received $£ 3,681,500$ of the promised funds, illustrating their contemptuous relationship with the Treasury, which was headed by the free-trader Winston Churchill between 1924-9. See Constantine, "Buy and Build," 15.

433 "Empire Marketing." The Times, June 2, 1930, 15.

${ }^{434}$ Chan, "'Remember the Empire Filled with Your Cousins,", 116.
} 
transporting goods was not simple. The cultivation and shipment of goods across the globe made attempts at substituting Empire products for foreign ones challenging. Diseases killed off crops. Pests destroyed stores. Some products went bad or were damaged before they made it to their destination, leading to financial loss for producers. The work that went into its research attempted to make the Empire into an efficient machine of production. But with the ecological problems that came along with largescale agriculture, their goals of securing adequate stores of food to reorient trade toward the Empire at the expense of foreign imports was ultimately unworkable. Their attempts at trying to reach the public and appeal to their interest was similarly unlikely, as observers pointed out that the public largely remained unaware of the EMB's research work.

Its marketing endeavors similarly showed that Empire products were often of lesser quality than some of their competition. Some countries and brands had spent decades building up the quality of their products, and these directly competed with Empire goods. Other problems such as the limits of geography and supply were also an issue. The lack of regulation on labeling the origin of goods similarly meant that encouraging consumers to "Buy Empire" was not as easy as it might seem. Price was also still a major concern for many consumers and that may have affected sales more than any other factor. Additionally, some - such as agriculture interests - were angered at the prospect of paying taxes to "direct trade artificially" and induce the consumption of rival 
goods. ${ }^{435}$ The antagonism between national and imperial interests required continual negotiation, which ultimately weakened the EMB's initial goals.

The publicity work similarly sought to show that value of imperial cooperation and coordination through posters, films, shopping weeks, lectures, and the radio. The portrayal of the Empire through visual media especially sought to make distant people familiar and more fully link the Empire together. Through the portrayal of Empire producers, the Board sought to illustrate how the "imperil family" might work together to assist in maintaining the imperial strength of the Empire. Women and the working classes, newly enfranchised, were envisioned as another important component. However, the portrayal of the Empire and the system that would sustain it was largely based on a narrow vision that obscured the economic and social realities of the time and only served to reinforce the underdevelopment of the Empire. It was simply underdevelopment rebranded.

The utilization of networks of experts to encourage the imperial reimagining of the Empire illustrated the extensive resources that were required to make the Empire, in some form, function. Scientists, agricultural experts, distributors, retailers, shippers, advertising professionals, and filmmakers - among other authorities - were called on to advise the EMB on the best strategies to increase Empire trade. It signaled the varied expertise that the government needed in order to make such an imperial mission possible. It also illustrated the encroachment of experts into the government arena. It signaled the mutual cooperation that was required between the bureaucracy of state and other

435 “The Trade Union Bill Passed Through,” The Spectator, July 22, 1927. 
scientific, business, and cultural authorities. The alliances of complimentary interests to gain funds, legitimacy, and knowledge thus show that the web of influence was vast.

Much of the Board's work continued on in different guises after the formal end of its work. Scientific research continued under the Colonial Development Fund. The Imperial Economic Committee, the group of British and Dominion representatives which helped to form the EMB, continued and much of the market research and intelligence work of the EMB resumed. Investigation on trade and commodities were broadened into "world surveys" in the late 1930's that expanded the focus to global, rather than Empire, trade and investigated new commodities to gain further insight and data about the intricates of world trade. ${ }^{436}$ Dominion governments also developed their own marketing campaigns after the dissolving of the EMB. ${ }^{437}$ Publicity work in respect to trade was transferred to the Department of Overseas Trade and its commissioners. The EMB's film unit was transferred to the General Post Office, and Grierson, Tallents and many of the EMB's directors continued to produce films through the GPO.

During the Buy British campaign, Israel Sieff of Marks and Spencer's department store pointed out that for a time, "it had been possible to sell a slightly inferior article in competition with a foreign article at the same price. This psychological impetus soon commenced to want for the reason that it was not built upon a sound economic basis." Any further measures "Would depend upon the measure in which it was related to realities rather than impressions." The EMB's goal at the outset had been to cultivate an

\footnotetext{
${ }^{436}$ Murton, "John Bull and Sons," 242

${ }^{437}$ Thackeray, Forging a British World of Trade, 59.
} 
imperial consciousness in the mind of consumers. The "psychological impetus" of appealing to imperial patriotism and the entirety of the Commonwealth were projections that were encouraged by Board, but they largely did not fit within the realities of the period. The move to create an Empire market had been thwarted by consumer preferences, and though the onset of the Depression provided a powerful deus ex machina to the movement toward imperial cooperation, the EMB's work can be read against the desires of consumers who ultimately preferred and relied on foreign goods.

Though the Empire Marketing Board would seek to create a narrative of imperial cohesion - through the projection of bountiful commodities that might be cultivated for international trade and manufactured with the help of empowered workers and British industrial strength - the reality of the situation was much different than the idyllic vision that the EMB propagated. Decreasing industrial power and domestic problems such as unemployment, labor unrest, a growing critique of Empire, and emerging nationalist sentiments abroad challenged British dominance. The EMB was forced to sell the concept of "Empire" because it was an economic and political imperative, signaling the diminished role of Britain during the interwar period. It was forced to sell a concept of British Empire that was ultimately unsustainable in the long term. For these reasons, the works of the EMB provides a unique vantage point from which to examine the Empire and its shifting economic, political, and social dynamics and cultural spheres. Through networks of influence, the EMB made consumers the central focus of their work and their importance helps to illustrate consumer's central role within the narrative of British imperialism. 


\section{$\underline{\text { Bibliography }}$}

$\underline{\text { Archives }}$

The National Archives (TNA)

Colonial Office (CO)

Board of Trade (BT)

Treasury (T)

British Library (BL)

India Office Records and Private Papers (IOR)

Government Reports (E.M.B)

Barber, C.A. Tropical Agricultural Research in the Empire: With Special Reference to Cacao, Sugar Cane, Cotton and Palms. London: HMSO, 1927.

Empire Marketing Board. Dairy Produce: A Summary of Figures of Production and Trade Relating to Butter, Cheese, Preserved Milk, Eggs, Egg Products. London: HMSO, 1932.

Empire Marketing Board. Fibres: A Summary of Figures of Production and Trade Relating to Cotton, Wool, Silk, Hemp, Flax, Jute. London: HMSO, 1932.

Empire Marketing Board. Fruit: A Summary of Figures of Production and Trade Relating to Apples, Pears, Bananas, Citrus Fruit, Grapes, Wine, Raisins and Currents. London: HMSO, 1932.

Empire Marketing Board. EMB. Further Changes in the Demand for Butter July 1928 and July 1931: Report of an Investigation by the Economic Section of the Empire Marketing Board into the Retail Marketing of Butter in Nottingham. London: HMSO, 1932.

Empire Marketing Board. Geophysical Surveying: Report of a Sub-Committee of the Committee of Civil Research. London: HMSO, 1927.

Empire Marketing Board. Grain Crops: A Summary of Figures of Production and Trade Relating to Wheat, Wheat Flour, Barley, Oats, Maize, Rice, Rye. London: HMSO, 1932.

Empire Marketing Board. May 1927 to May 1928. London: HMSO, 1928.

Empire Marketing Board. May 1928 to May 1929. London: HMSO, 1929

Empire Marketing Board. May 1929 to May 1930. London: HMSO, 1930.

Empire Marketing Board. May 1931 to May 1932. London: HMSO, 1931. 
Empire Marketing Board. Meat: A Summary of Figures of Production and Trade Relating to Beef, Cattle, Mutton \& Lamb, Sheep, Bacon \& Hams, Pigs, Pork, Canned Meat. London: HMSO, 1932.

Empire Marketing Board. Note on the Work and Finance of the Board and Statement of Research and Other Grants Approved by the Secretary of State for Dominion Affairs from July, 1926 to March 31 st., 1928. London: HMSO, 1928.

Empire Marketing Board. Oilseeds and Vegetable Oils: A Summary of Figures of Production and Trade Relating to Copra, Groundnuts, Cottonseed, Linseed, Olive Oil Soya Beans, Sesame Seed, Rapeseed, Palm Kernels, Palm Oil, Whale Oil. London: HMSO, 1932.

Empire Marketing Board. Plantation Crops: A Summary of Figures of Production and Trade Relating to Sugar, Tea, Coffee, Spices, Cocoa, Rubber, Tobacco. London; HMSO, 1932.

Empire Marketing Board. The Demand for Empire Butter: Report of an Investigation by the Economic Section of the Empire Marketing Board in to the Retail Marketing of Butter in the United Kingdom (London: HMSO, 1930).

Powell, H. Clark. Grapefruit Culture in the British West Indies and British Honduras. London: HMSO, 1928.

Sampson, H.C. Report on the Development of Agriculture in British Honduras. London: HMSO, 1929.

Report on Development of Agriculture in Trinidad. London: HMSO, 1927.

Report on Development of Agriculture in British Guiana. London: HMSO, 1927.

Report on Development of Agriculture in the Leeward and Windward Islands and Barbados. London: HMSO, 1927.

Other Primary Sources

“Agricultural Bureau," Huron Times (Franklin, Tas.) February 19, 1932.

Amery, L.S. The Empire in the New Era, Speeches Delivered During an Empire Tour 1927-1928. London: E. Arnold \& Co, 1928.

The Forward View. London: Geoffrey Bles, 1935.

My Political Life. London: Hutchinson, 1953. 
Boyd, Charles W. ed. Mr. Chamberlain's Speeches: With an Introduction by the Right Hon. Austen Chamberlain, M.P. Volume II. London: Constable \& Company, 1914.

“Britain After the War.” Saturday Evening Post. January 28, 1918.

"Buy British." The Times, November 14, 1931.

"'Buy British' Campaign." The Times, 12 Nov. 1931.

"Christmas Food from the Empire." The Times, December 24, 1926.

Cobden Club. Fact Versus Fiction: The Cobden Club's Reply on Mr. Chamberlain. Cassel \& Company: London, 1904.

Colonial Development Bill. 23 July 1929. Parliamentary Debates, Lords, vol. 75 cc17490.

Cargo from Jamaica. Directed by Basil Wright. Directed by Basil Wright. 1933;

London, UK: Empire Marketing Board. Colonial Film Catalogue. http://www.colonialfilm.org.uk/node/784

"Christmas Food from the Empire." The Times, December 24, 1926.

“Display Advertising.” The Times, November 11, 1927.

Drifters. Directed by John Grierson. 1929; London, UK: Empire Marketing Board. Silent Film Online. http://search.alexanderstreet.com.proxy.lib.pdx.edu/view/work/2126318.

Elliot, Walter. "Research: A Bond of Empire." The Spectator 145, no. 5343. (November 22, 1930): 772-773.

“Empire Christmas Puddings.” The Times, December 5, 1924.

"Empire Development Union in Plans for an Economic Policy." Ottawa Citizen. January 26, 1923.

“Empire Marketing." The Times, June 2, 1930.

Empire Marketing Board. 18 July 1927. Parliamentary Debates, Lords, vol. 68, cc 588601.

“Empire Marketing Board Annual Report.” Northern Times, November 29, 1933. 
“EMPIRE PRODUCTS.” The Sydney Morning Herald, 20 July 1928.

"Foreign Butter Sold as English." The Times, February 14, 1930.

"General Strike in Great Britain." Advocate of Peace Through Justice 88, no. 6 (June 1926): 338-378.

Gladstone, W.E. The Financial Statement - The Budget, 18 April 1853. Parliamentary Debates, Commons, vol. 125, cc 1416.

"Graded Produce." The Times, 20 November 1928.

Graeme, P. Lloyd. National Archives. Cabinet Papers. "Proposals for Financial Assistance to Accelerate the Development of Imperial Resources." August $2,1929$.

Grierson, John. Grierson on Documentary. London: Collins, 1946.

Hankey, M.P.A. National Archives of the UK. Cabinet Memorandum. Cabinet Conclusion Bill 2. Import Duties Bill. London, England. 1932. http://filestore.nationalarchives.gov.uk/pdfs/small/cab-23-70-cc-11-3211.pdf

Hobson, J.A. "The Political Significance of Imperialism," in Empire Writing: An Anthology of Colonial Literature 1870- 1918, 295-297. Edited by Elleke Boemer. New York: Oxford University Press, 1998.

Hudson, W.J., and Wendy Way, eds., Letters from 'A Secret Service Agent': F.L. McDougall to S.M. Bruce 1924-1929, Department of Foreign Affairs, Australian Government Publishing Service, Canberra, 1986.

Huxley, Gervais. Both Hands. London: Chatto \& Windus, 1970.

Leighton, Gerald and Mabel L. Clark, "Milk Consumption and the Growth of School Children, Second Preliminary Report on Test to the Scottish Board of Health," British Medical Journal 1:3548 (Jan. 5, 1929): 23- 25.

Lloyd, E.M.H. Stabilization: An Economic Policy for Producers and Consumers. New York: A.A. Knopf, 1923.

Lloyd, Sampson S. The Fair-Trade Position Explained: Being a Series of Three Letters Addressed by Mr. Sampson S. Lloyd as Chairman of the Free Trade League, to the Times and other Newspapers. London: The National Fair-Trade League, 1884. 
Kipling, Rudyard. One Family. Directed by Walter Creighton. 1930; London, UK: Empire Marketing Board. Colonial Film Catalogue. http://www.colonialfilm.org.uk/node/40

“Marking of Imported Foodstuffs,” The Times, February 27, 1933.

McDougall, F.L. Sheltered Markets. London: J. Murray, 1925.

McDougall, F.L. "The Empire Marketing Board and Empire Economic Affairs," The Economic Record 4 (February 1928): 135-151.

"Meaning of the British Empire Exhibition," Advocate of Peace Through Justice 86, no. 6 (June 1924): 330 - 334.

Medley, George W. The Reciprocity Craze: A Tract for the Times. Castell, Petter, Galpin, \& Co. London, Paris, New York, 1881.

“Mr. Chamberlain on Trade,” The Times, 1 April 1895.

National Archives. UK Public General Acts. Statute of Westminster, 1931. http://www.legislation.gov.uk/ukpga/1931/4/pdfs/ukpga_19310004_en.p df

The National Archives Website: Discovery: Records of the Cabinet Office. CAB/24/161. Overseas Settlement Within the Empire. 1 August 1923. Available at http://filestore.nationalarchives.gov.uk/pdfs/small/cab-24-158-CP-35.pdf

The National Archives Website: Discovery: Records of the Cabinet Office. CAB/24/158. Empire Migration: Memorandum by the Secretary of State for the Colonies. 23 January 1923. Available at http://filestore.nationalarchives.gov.uk/pdfs/small/cab24-158-CP-35.pdf

The National Archives Website: Discovery: Records of the Cabinet Office: CAB 24/158. Proposals for Financial Assistance to Accelerate the Development of Imperial Resources. Joint Memorandum by the Secretary of State for the Colonies and the President of the Board of Trade. 8 February 1923. Available at http://filestore.nationalarchives.gov.uk/pdfs/small/cab-24-158-CP-90.pdf

The National Archives Website: Discovery: Records of the Cabinet Office. CAB 24/161 Imperial Economic Conference (Documents) Committee Report. 30 July 1923. Available at http://discovery.nationalarchives.gov.uk/details/r/D7725650 
Orr, J.B. "Milk Consumption and the Growth of School Children," The Lancet 211, no. 5448 (1928): 202-203.

“Our Colonial Allies.” The Spectator. October 3, 1863.

OUR DRAMATIC CRITIC. "Films of Substance.” The Times. April 2, 1932.

Sampson, H.C. "The Royal Gardens, Kew, and Empire Agriculture.” Journal of the Royal Society of Arts 83, no. 4295 (March 15, 1935): 404-419.

Tallents, Stephen, "The Birth of the British Documentary (Part I)." Journal of the University Film Association 20, no. 1 (1968): 15-21.

"The Birth of the British Documentary (Part II)." Journal of the University of Film Association 20, no. 2 (1968): 27-32.

_ “British Documentary Films.” The Spectator, November 19, 1937.

"The Projection of England," in Public Relations and the Making of Modern Britain: Stephen Tallents and the Birth of a Progressive Media Profession, edited by Scott Anthony: 206-235. Manchester:

Manchester University Press, 2012.

Tariff Reform League. "Monthly Notes on Tariff Reform.” No. 1 Vol. XV. July 1911.

Thomas, James Henry. The National Archives. Cabinet Papers. "The Statute of Westminster." Memorandum by the Secretary of State for Dominion Affairs. September, 1931.

"Trade in Empire Produce." The Times, October 1, 1926.

“The Trade Union Bill Passed Through,” The Spectator, July 22, 1927.

Windmill in Barbados. Directed by Basil Wright. 1933; London, UK: Empire Marketing Board. Colonial Film Catalogue. http://www.colonialfilm.org.uk/node/6734

"Windmill in Barbados," Sight and Sound, Autumn 1933. 


\section{$\underline{\text { Secondary Sources }}$}

Adas, Michael. Machines as the Measure of Men: Science, Technology, and Ideologies of Western Dominance. Ithaca: Cornell, 1986.

Aitken, Rob. "Provincializing Embedded Liberalism: Film, Orientalism, and the Reconstruction of World Order," Review of International Studies 37, no. 4 (October 2011): 1695-1720.

Anthony, Scott. Public Relations and the Making of Modern Britain: Stephen Tallents and the Birth of a Progressive Media Profession. Manchester: Manchester University Press, 2011.

Atkins, Peter. "School Milk in Britain, 1900-1934. Journal of Policy History 19, no. 4 (2007): 395- 427.

Atkins, P.J. "Food and the Empire Marketing Board in Britain, 1926-1933." Paper presented at the 8th Symposium of the International Commission for Research into European Food History. Prague, Czech Republic, September 30 - October 5, 2003.

Bali, Selcuk. "Comparisons Between the Long Depression, Great Depression, and the Global Financial Crisis," International Journal of Management Economics and Business 8, no. 16 (2012): 223-244.

Ball, Stuart. "The Conservative Party, The Role of the State and the Politics of Protection, c. 1918-1932." Journal of the Historical Association 96, no. 323 (July 2011): 280-303.

Bairoch, Paul. "Free Trade and European Economic Development in the $19^{\text {th }}$ Century," European Economic Review 3 (1972): 211-245.

Ballantyne, Tony. Orientalism and Race: Aryanism and the British Empire. London: Palgrave Macmillan, 2002.

Barnes, Felicity. "Bringing Another Empire Alive? The Empire Marketing Board and the Construction of Dominion Identity, 1926- 33." The Journal of Imperial and Commonwealth History 42, no. 1 (2014): 65-81.

Barnes, Felicity and David M. Higgins, "Brand Image, Cultural Association and Marketing: 'New Zealand' Butter and Lamb Exports to Britain, c. 1920-1938." Business History (2007): 1-28.

Beattie, James. "Recent Themes in Environmental History," History Compass 10, no. 2 (2012): 129-139. 
Beattie, James, Edward Melillo and Emily O'Gorman 'Introduction: Eco-Cultural Networks and the British Empire, 1837-1945." In Ecocultural Networks and the British Empire: New Views on Environmental History, ed. James Beattie, Edward Melillo and Emily O'Gorman. London: Bloomsbury, 2015.

Behal, Rana P. "Forms of Labour Protest in Assam Valley Tea Plantations, 1900-1930," Economic and Political Weekly 20, no. 4 (Jan. 26, 1984): 19-26.

"Power Structure, Discipline, and Labour in Assam Tea Plantations Under Colonial Rule," International Review of Social History 51 (2006): 143-172.

Beinart, William and Lotte Hughes, Environment and Empire. Oxford: Oxford University Press, 2007.

Bell, Duncan. The Idea of Greater Britain: Empire and the Future of World Order, 18601900. Princeton: Princeton University Press, 2007.

Benians, E.A. "Chapter VI: Finance, Trade and the Communications 1870-1895." In The Cambridge History of the British Empire, Volume II: The Empire-

Commonwealth, edited by E.A. Benians, Sir James Butler, and C.E. Carrington. Cambridge: Cambridge University Press, 1967.

Boyce, Robert. "The Significance of 1931 for British Imperial History," Histoire@Politique 11:2 (2010): 1-17.

The Great Interwar Crisis and the Collapse of Globalization. Hampshire: Palgrave Macmillan, 2009.

Brown, Andrew G. Reluctant Partners: A History of Multilateral Trade Cooperation. Ann Arbor: University of Michigan Press, 2003.

Brown, Kenneth D. "The Trade Union Tariff Reform Association, 1904-1913.” Journal of British Studies 9:2 (May 1970): 141-153.

Buck, Tim. "Imagining Imperial Modernity in British Colonial West Africa: Gerald Spencer Pryse's Work for the Empire Marketing Board," Art History 38, no. 5 (November 2015): 940-963.

Buckley, Cheryl. Designing Modern Britain. London: Reaktion, 2007.

Burton, Antionette. Burdens of History: British Feminists, Indian Women and Imperial Culture,1865-1915. Chapel Hill; London: University of North Carolina Press, 1994. 
Cain, P.J. and A.G. Hopkins, "Gentlemanly Capitalism and British Expansion Overseas. Part I: The Old Colonial System, 1688-1850." Economic History Review, $2^{\text {nd }}$ ser., 39, no. 4 (1986): 501-25; and "Part II: The New Imperialism, 1850-1945," Economic History Review 40, no. 1 (1987): 1-26.

Capie, Forrest. "The Sources and Origins of Britain's Return to Protection, 1931-2," in Andrew Marrison, Free Trade and it's Reception, 1815-1960. London; New York: Routledge, 2003.

Cannadine, David. “The Empire Strikes Back," Past and Present 147 (May 1995), 180194.

Chan, Nadine. "'Remember the Empire Filled with Your Cousins': Poetic Exposition in the Documentaries of the Empire Marketing Board." Studies in Documentary Film 7, no. 2 (2013): 105-118.

Chase, Kerry A. "Imperial Protection and Strategic Trade Policy in the Interwar Period." Review of International Political Economy 11, no. 1 (February 2004): 177-203.

Clavin, Patricia. Securing the World Economy: The Reinvention of the League of Nations, 1920-1946. Oxford: Oxford University Press, 2013.

Clayton, Huw. "How Not to Run a Political Campaign: The Failure of The Unionist Free Traders 1903-6." Parliamentary History 30, no. 2 (2011): 158-174.

Clegg, H.A. A History of British Trade Unions Since 1889. Vol. 2: 1911-33. Oxford: Oxford University Press, 1985.

Constantine, Stephen. The Making of British Colonial Development Policy 1914-1940. London: Routledge, 1984.

'Bringing the Empire Alive,' The Empire Marketing Board and Imperial Propaganda, 1926-33." In Propaganda and Empire: The Manipulation of British Public Opinion, ed. John Mackenzie. Manchester: Manchester University Press, 1986.

Buy \& Build: The Advertising Posters of the Empire Marketing Board. London: H.M.S.O, 1986.

Cronin, Mike. "Selling Irish Bacon: The Empire Marketing Board Artists of the Free State," Eire-Ireland 39, no. 3 \& 4 (Fall/Winter 2004): 132-143.

Crosby, Alfred W. Ecological Imperialism: The Biological Expansion of Europe, 9001900. Cambridge: Cambridge University Press, 1986. 
De Bromhead, Alan. "Women Voters and Trade Protectionism in the Interwar Years" Queens University Centre for Economic History Working Paper Series 15, no. 3 (2015): 22-46.

Dilley, A.R, “The Economics of Empire.” In The British Empire: Themes and Perspectives, ed. Sarah Stockwell. Malden: Blackwell, 2008.

Drayton, Richard. Nature's Government: Science, Imperial Britain, and the 'Improvement' of the World. New Haven: Yale University Press, 2000.

Druick, Zoe. "'Reaching the Multimillions': Liberal Internationalism and the Establishment of Documentary Film." In Inventing Film Studies, ed. Lee Grieveson and Haidee Wasson. Durham: Duke University Press, 2008.

Duncan, R. "The Demand for Frozen Beef in the United Kingdom, 1880-1940," Journal of Agricultural Economics 12, no. 1 (June 1954): 82-88.

Eichengreen, Barry and Douglas A. Irwin. "The Slide to Protectionism in the Great Depression: Who Succumbed and Why?" The Journal of Economic History 70, no. 4 (December 2010): 871-897.

Eschner, Kat. “The 1870’s Dairy Lobby Turned Margarine Pink So People Would Buy Butter," May 23, 2017. Smithsonian https://www.smithsonianmag.com/smartnews/1870s-dairy-lobby-turned-margarine-pink-so-people-would-buy-butter$180963328 /$

Etherington, Norman. Theories of Imperialism: War, Conquest and Capital. London; Canberra, Croom Helm, 1984.

Fernandez, Eva. "Selling Agricultural Products: Farmers' Co-Operatives in Production and Marketing, 1880-1930," Business History 56, no. 4 (2014): 547-568.

Fitzgerald, Robert. "Marketing Management in Britain: What is the Evidence for 'Failure?' In Business in Britain in the Twentieth Century, ed. Richard Coopey and Peter Lyth. Oxford: Oxford University Press, 2009.

Foy, Lydia. The Art of Persuasion: Posters of the Empire Marketing Board 1926-1933. Ottawa: National Archives of Canada, 1990.

French, M. "Modernity in British Advertising: Selling Cocoa and Chocolate in the 1930s," Journal of Historical Research in Marketing 9, no. 4 (2017): 451-466.

French, Michael. and Jim Phelps Cheated Not Poisoned? Food Regulation in the United Kingdom, 1875-1938. Manchester: Manchester University Press, 2009. 
Garside, W.R. "Party Politics, Political Economy and British Protectionism, 1919-1932," History 83, no. 269 (January 1998): 47-65.

Ghosh, Durba. "Another Set of Imperial Turns?" American Historical Review 117, no. 3 (June 2012): 772-793.

Greaves, Julian. Industrial Reorganization and Government Policy in Interwar Britain. London: Routledge, 2005.

Grieveson, Lee and Colin MacCabe. Empire and Film: London: Palgrave Macmillan on Behalf of the British Film Institute, 2011.

"Empire Marketing Board," Colonial Film: Moving Images of the British Empire. 2008. http://www.colonialfilm.org.uk/productioncompany/empire-marketing-board.

Grampp, William D. "How Britain Turned to Free Trade." The Business History Review 61, no. 1 (Spring 1987): 86-112.

Grayson, Richard S. "Imperialism in Conservative Defense and Foreign Policy: Leo Amery and the Chamberlains, 1903-39." The Journal of Commonwealth History 34, no. 4 (2006): 505-527.

Gorman, Daniel. The Emergence of International Society in the 1920's. Cambridge: Cambridge University Press, 2012.

Grant, Mariel. Propaganda and the Role of the State in Inter-War Britain. Oxford: Oxford University Press, 1994.

Gurney, Peter. The Making of Consumer Society in Britain. London: Bloomsbury, 2017.

"Rejoicing in Potatoes': The Politics of Consumption in England During the 'Hungry Forties," Past and Present 23 (May 2009), 99-136.

Grieveson, Lee. Cinema and the Wealth of Nations: Media, Capital, and the Liberal World System. Berkeley: University of California Press, 2017.

Hall, Catherine. Civilising Subjects: Metropole and Colony in the English Imagination, 1830-1867. Oxford: Polity, 2002.

Hawkins, Richard. "The Cooperative Marketing of Hawaiian Pineapple, 1908-39," Conference of Historical Analysis and Research in Marketing, May 17-20, 2007, Durham, NC, 251-262. 
Headrick, David. The Tentacles of Progress: Technology Transfer in the Age of Imperialism, 1850-1940. Oxford: Oxford University Press, 1988.

Heffernan, Mike and Benjamin J. Thorpe "'The Map that Would Save Europe: Clive Morris-Bell, the Tariff Walls Map, and the Politics of Cartographic Display." Journal of Historical Geography 60 (2018): 24-40.

Henderson, David. Innocence and Design: The Influence of Economic Ideas on Policy Oxford: Blackwell, 1986.

Higgins, David M. Brands, Geographical Origin, the Global Economy: A History from the Nineteenth Century to the Present. Cambridge: Cambridge University Press, 2018.

Higgins, David and Mads Mordhorst, "Reputation and Export Performance: Danish Butter, Exports and the British Market, c. 1880-1914," Business History 50, no. 2 (2008): 185-204.

Higgins, David M. And Britain D. Varian, "Money Talks - Give Yours an Empire Accent:' The Economic Failure of the Empire Marketing Board, 1926-1933" (2019) paper presented at the Economic History Society's 2019 annual conference.

Hobson J.A., Imperialism: A Study. Nottingham: Spokesman, 2011.

Horton, Melanie. Empire Marketing Board Posters: Manchester Art Gallery. London: Scala, 2010.

Howe, Anthony. Free Trade and Liberal England, 1846-1946. Oxford: Clarendon, 1997.

"State Versus Market in the Early Historiography of the Industrial Revolution c. 1890-1914." European Journal of Economic Thought 23, no. 6 (2016): 897-918.

Howe, Stephen ed. "Introduction," The New Imperial History Reader. London; New York: Routledge, 2010.

Hodge, Joseph M. Triumph of the Expert: Agrarian Doctrines of Development and the Legacies of British Colonialism. Athens: Ohio University Press, 2007.

"Science, Development and Empire: The Colonial Advisory Council on Agriculture and Animal Health, 1929-43," Journal of Imperial and Commonwealth History 30, no. 1 (2002): 1-26. 
Jackson, Simon and Alanna O’Malley, "Rocking on its Hinges? The League of Nations, the United Nations and the New History of Internationalism in the Twentieth Century," in The Institution of International Order: From League of Nations to the United Nations. London; New York: Routledge, 2018.

Jeronimo, Miguel Bandeira. "A League of Empires: Imperial Political Imagination and Interwar Internationalisms," in Internationalism, Imperialism and the Formation of the Contemporary World, Miguel Bandeira Jeronimo and Jose Pedro Montiero eds. Palgrave Macmillan, 2018.

Jons, Heike. "The University of Cambridge, Academic Expertise and the British Empire, 1885-1962," Environment and Planning 48, no. 1 (2016): 94-114.

Kendle, John. Federal Britain: A History. London; New York: Routledge, 1997.

Kenez, Peter. The Birth of the Propaganda State: Soviet Methods of Mass Mobilization 1917-1929. Cambridge: Cambridge University Press, 1985.

Keown, Gerard. First of the Small Nations: The Beginning of Irish Foreign Policy in the Interwar Years. Oxford: Oxford University Press, 2016.

Kennedy, Dane. The Imperial History Wars: Debating the British Empire. London: Bloomsbury, 2018.

Kindleberger, Charles P. Historical Economic: Art or Science. Berkeley: University of California Press, 1990.

Knowles, William H. "Supervision in the British West Indies: Source of Labor Unrest," Industrial and Labor Relations Review 8, no. 4 (July 1955): 572-580.

Kothari, Uma. "Trade, Consumption and Development Alliances: The Historical Legacy of the Empire Marketing Board Poster Campaign." Third World Quarterly 35, no. 1 (2014): 43-64.

Kruger, Daniel H. "Hobson, Lenin, and Schumpeter on Imperialism," Journal of the History of Ideas 16, no. 2 (April 1955): 252-259.

Lampe, Marcus and Paul Sharp. "Greasing the Wheels of Rural Transformation? Margarine and the Competition for the British Butter Market," The Economic History Review 67, no. 3 (2014): 769-792.

Lenin, Vladimir. Imperialism: The Highest Stage of Capitalism. Peking: Foreign Language Press, 1975.

Lester, Alan. "Imperial Circuits and Networks: Geographies of the British Empire," 
History Compass 4, no. 1 (December 2005): 124-141.

L'Etang, Jacquie. "State Propaganda, and Bureaucratic Intelligence: The Creation of Public Relations in the $20^{\text {th }}$ Century," Public Relations Review 24, no. 4 (1998): 413-441.

Loftus, Donna. "Markets and Culture," in New Directions in Social and Cultural History, ed. Sasha Handley, Rohan McWilliam, and Lucy Noakes. London: Bloomsbury, 2018.

Lysack, Krista. Come Buy, Come Buy: Shopping and the Culture of Consumption in Victorian Women's Writing Athens: Ohio University Press, 2008.

Maclachlan, Patricia and Frank Trentmann, "Civilizing Markets: Traditions of Consumer Politics in Twentieth-Century Britain, Japan and the United States," in Markets in a Historical Context: Ideas and Politics in the Modern World. Cambridge: Cambridge University Press, 2004.

Manela, Erez. The Wilsonian Moment: Self-Determination and the International Origins of Anticolonial Nationalism. New York: Oxford University Press, 2007.

Marrison, A.J. "Businessmen, Industries and Tariff Reform in Great Britain." Business History 25, no. 2 (July 1983): 148-178.

Marrison, Andrew ed. Free Trade and its Reception 1915-1960: Freedom and Trade Volume I. Routledge: London, 1998.

Mazower, Mark. Governing the World: The History of an Idea. New York: Penguin, 2012.

McKenzie, Francine. Redefining the Bonds of Commonwealth, 1939-1948: The Politics of Preference. New York, Palgrave Macmillan, 2002.

McKenzie, John ed. Imperialism and Popular Culture. Manchester: Manchester University Press, 1986.

McLean, Ian and Camilla Bustani, "Irish Potatoes and British Politics: Interests, Ideology, Heresthetic and the Repeal of the Corn Laws," Political Studies 47 (1999): 817-836.

McCarthy, Helen, "The League of Nations, Public Ritual and National Identity in Britain, c. 1919-56." History Workshop Journal 70 (Autumn 2010): 108-132. 
McDonough, Frank. The Conservative Party and Anglo-German Relations, 1905-1914. Hampshire: Palgrave Macmillan, 2007.

Medley, George, M. The Reciprocity Craze: A Tract for the Times. Cobden Club Tract. Castell, Petter, Galpin, \& Co. London, Paris, New York, 1881.

Melillo, Edward D. "Empire in a Cup: Imagining Colonial Geographies Through British Tea Consumption," in Eco-Cultural Networks and the British Empire: New Views on Environmental History, ed. James Beattie, Edward Melillo, and Emily Gorman. London: Bloomsbury, 2015.

Meredith, David. "The British Government and Colonial Economic Policy 1919-1939," The Economic History Review, 28, no. 3 (August 1975): 484-499.

Meredith, David. "Imperial Images: The Empire Marketing Board, 192632," History Today (1987): 30-37.

Miller, Henry. "Popular Petitioning and the Corn Laws, 1833-46," The English Historical Review 127, no. 527 (2012): 882-919.

Miller, Henry James, "Free Trade and Print Culture: Political Communication in Early Nineteenth-Century England," Cultural and Social History 14, no. 1 (2017): 3554.

Moberg, Mark. "Crown Colony as Banana Republic: The United Fruit Company in British Honduras, 1900-1920," Journal of Latin American Studies 28, no. 2 (May 1996): 357-381.

Murton, James. "John Bull and Sons: The Empire Marketing Board and the Creation of a British Imperial Food System," in Edible Histories, Cultural Politics: Toward a Canadian Food History. Toronto: University of Toronto Press, 2012.

Naylor, Simon. "Spacing the Can: Empire, Modernity, and the Globalisation of Food," Environment and Planning 32 (2000): 1625-1639.

Nye, John Vincent. "The Myth of Free-Trade Britain and Fortress France: Tariffs and Trade in the Nineteenth Century." The Journal of Economic History 51, no. 1 (March 1991): 23-46.

O'Conner, Kaori. “The King's Christmas Pudding: Globalization, Recipes, and the Commodities of Empire." Journal of Global History 4, no. 1 (March 2009): 127-155. 
Olmstead, Alan L. and Paul W. Rhode, "The Evolution of California Agriculture, 18502000," in California Agriculture: Dimensions and Issues, ed. Jerome Siebert. UC Berkeley: Giannini Foundation of Agricultural Economics, 2003.

Opie, Robert. Rule Britannia: Trading on the British Image. Middlesex: Penguin, 1985.

Overseas Development Institute. Colonial Development: A Factual Survey of the Origins and History of British Aid to Developing Countries. London: Overseas Development Institute, 1964.

Palen, Marc-William. "Adam Smith as Advocate of Empire, c. 1870-1932." The Historical Journal 57, no. 1 (2014): 179-198.

"Foreign Relations in the Gilded Age: A British Free-Trade Conspiracy?" Diplomatic History 37, no. 2 (2013): 217-247.

"Protection, Federation and Union: The Global Impact of the McKinley Tariff upon the British Empire, 1890-94" The Journal of Imperial and Commonwealth History 38, no. 3 (September 2010): 395-418.

Pedersen, Susan. The Guardians: The League of Nations and the Crisis of Empire. New York: Oxford University Press 2015.

Pietsch, Tamson. Empire of Scholars: Universities, Networks and the British Academic World 1850-1939. Manchester: Manchester University Press, 2013.

Pitts, Jennifer. A Turn to Empire: The Rise of Imperial Liberalism in Britain and France Princeton: Princeton University Press, 2005.

Porter, Andrew. "'Gentlemanly Capitalism' and Empire: The British Experience Since 1750?" The Journal of Imperial and Commonwealth History 18, no. 3 (1990): 265-295.

Porter, Bernard. The Absent-Minded Imperialist: Empire, Society, and Culture in Britain. Oxford: Oxford University Press, 2002.

Price, Peter. "Stepping Stones to Imperial Unity?: The British West Indies in the LateVictorian Imperial Federation Movement," Canadian Journal of History 52, no. 2 (Autumn 2017): 240-263.

Pugh, Martin. "Women, Food and Politics 1880 - 1930," History Today 41, no. 3 (March 1991): 14-20.

Ramamurthy, Anandi. Imperial Persuaders: Images of Africa and Asia in British Advertising. Manchester: Manchester University Press, 2003. 
Rappaport, Erika. “Art, Commerce, or Empire? The Rebuilding of Regent Street, 1880-1927," History Workshop Journal 53 (Spring 2002): 94-117.

"Drink Empire Tea: Conservative Politics and Imperial Consumerism in Interwar Britain," in Consuming Behaviours: Identity, Politics and Pleasure in Twentieth-Century Britain, ed. Erika Rappaport, Sandra Dawson, and Mark J. Crowley. Bloomsbury: New York; London, 2015.

Reidi, Eliza. "Women, Gender, and the Promotion of Empire: The Victoria League, 1901-1914. The Historical Journal 45, no. 3 (2002): 569-599.

Rice, Tim. "Smart Collection: 5: Banana Cultivation and Trade, British Honduras 1930s," Context. (February 2008), Colonial Film Catalogue. http://www.colonialfilm.org.uk/node/3837.

Richards, Thomas. The Commodity Culture of Victorian England. Stanford: Stanford University Press, 1991.

Robinson, Ronald and John Gallagher. Africa and the Victorians: The 'Official Mind" of Imperialism. Basingstroke, 1961.

Rogers, Edmund. “A 'Small Free Trade Oasis'?: Agriculture, Tariff Policy, and the Danish Example in Great Britain and Ireland, c. 1885-1911." Scandinavian Journal of History 3, no. 1 (February 2013): 42-64.

Rupp, Rebecca. "The Butter Wars: When Margarine Was Pink," August 13, 2014. National Geographic. https://www.nationalgeographic.com/people-andculture/food/the-plate/2014/08/13/the-butter-wars-when-margarine-was-pink/

Salvadori, Neri and Rodolfo Signorino. "Defense versus Opulence? An Appraisal of the Malthus-Ricardo 1815 Controversy on the Corn Laws," History of Political Economy 47, no. 1 (2005): 151-184.

Schularick, Moritz and Solomos Solomou. "Tariffs and Economic Growth in the First Era of Globalization.” Journal of Economic Growth 16:1 (2011): 33-70.

Schultz, John. "Leaven for the Lump': Canada and Empire Settlement, 1918-1939." In Emigrants and Empire: British Settlement in the Dominion between the Wars, ed. Stephen Constantine. Manchester: University of Manchester Press, 1990.

Schumpeter, Joseph. Imperialism and Social Classes. New York, A.M. Kelly, 1951.

Schwarzkopf, Stephen. "Market, Consumers, and the State: The Uses of Market Research 
in Government and the Public Sector, 1925-1955." In The Rise of Marketing and Market Research, Ed. Hartmut Berghoff, Philip Scranton, and Uwe Spiekermann. New York: Palgrave MacMillan, 2012.

"Market Research, Product Innovation, and the Creation of Brand Loyalty in Britain and the United States in the Interwar Years," Journal of Macromarketing 29, no. 1 (2009), 10.

"Classes to Masses: How Advertising Agencies Responded to the Challenges of the Mass Market in Interwar Britain," Paper given at the Economic History Society Annual Conference, University of Reading, March 31-April 2, 2006, 2.

"Creativity, Capital, and Knowledge: The Crawford Agency and British Advertising in the Interwar Years," Journal of Cultural Economy 1, no. 2 (2008), 193.

Soluri, John. "Accounting for Taste: Export Bananas, Mass Markets, and Panama Disease," Environmental History 1, no. 7 (July 2002), 383-410.

Speek, Sven. "Ecological Concepts of Development? The Case of Colonial Zambia," in Developing Africa: Concepts and Practices in Twentieth Century Colonialism, ed. Joseph M. Hodge, Gerald Hodl, and Martina Kopf. Manchester: Manchester University Press, 2014.

Stollery, Martin, Alternative Empires: European Modernist Cinemas and Cultures of Imperialism. Exeter: University of Exeter Press, 2000.

Syriatou, Athena. "National, Imperial, Colonial and Political: British Imperial Histories and their Descendants." Historein 12 (2013): 38-67.

Thackeray, David. "Home and Politics: Women and Conservative Activism in Early Twentieth-Century Britain. Journal of British Studies 49, no. 4 (October 2010): 826-848.

"The Crisis of the Tariff Reform League and the Division of 'Radical Conservatism,' c. 1913-1922." History 91, no. 301 (2006): 45-61.

"Rethinking the Edwardian Crisis of Conservatism." The Historical Journal 54, no. 1 (2011): 191-213.

Forging a British World of Trade: Culture, Ethnicity, and Market in the Empire-Commonwealth, 1880-1975. Oxford: Oxford University Press, 2019. 
"Buying for Britain, China, or India? Patriotic Trade, Ethnicity, and Markets in the British Empire/Commonwealth," Journal of Global History 12, no. 3 (November 2017): 386-409.

Thomas, Martin and Andrew Thompson. "Empire and Globalisation: From 'High Imperialism' to Decolonisation," The International History Review, 36, no. 1 (2014): 142-170.

Thompson, Andrew S. Imperial Britain: The Empire in British Politics, c. 1880-1932. Harlow; New York, Longman, 2000.

Thompson, James. "'Pictorial Lies'? Posters and Politics in Britain c. 1880-1914." Past \& Present 197 (November 2007): 177-210.

Tilley, Helen. Africa as a Living Laboratory: Empire, Development, and the Problem of Scientific Knowledge. Chicago: University of Chicago, 2011.

Trentmann, Frank. Free Trade Nation: Commerce, Consumption and Civil Society in Modern Britain. Oxford; New York: Oxford University Press, 2008.

Valkoun, Jaroslav. "Great Britain, the Dominions, and the Paris Peace Conference," West Bohemian Historical Review 4, no. 2 (2014): 145-162.

Van Dam, Peter. "Tales of the Market: New Perspectives on Consumer Society in the $20^{\text {th }}$ Century," UvA-DARE (2015): 1-47.

Vernon, James. The Cambridge History of Britain: Modern Britain 1750 to the Present. Cambridge: Cambridge University Press, 2017.

Way, Wendy. A New Idea Each Morning: How Food and Agriculture Came Together in One International Organization. Canberra: Australian National University E Press, 2013.

Williamson, Philip. National Crisis and National Government: British Politics, the Economy, and Empire, 1926-1932. Cambridge: Cambridge University Press, 1992.

Wilson, Kathleen. A New Imperial History: Culture, Identity and Modernity in Britain and the Empire 1660-1840. Cambridge: Cambridge University Press, 2004.

Worboys, Michael. 'British Colonial Science Policy, 1918-1939," in Les Sciencies Coloniales: Figures et Institutions, ed. Patrick Petitjean (Paris: Orstom, 1996): 99-111.

Waqar Zaidi, "Liberal Internationalist Approaches to Science and Technology in Interwar 203 
Britain and the United States." In Internationalism Reconfigured: Transnational Ideas and Movements Between the War, ed. Daniel Laqua. London: I.B. Taurus, 2011.

Zimmern, Alfred. The Third British Empire: Being A Course of Lectures Delivered at Columbia University, New York. Westport: Greenwood Press, 1979 